POLITICAL REALISM IN APOCALYPTIC TIMES

\author{
A Dissertation \\ Presented to the Faculty of the Graduate School \\ of Cornell University \\ In Partial Fulfillment of the Requirements for the Degree of \\ Doctor of Philosophy
}

By

Alison Elizabeth Jennifer McQueen

January 2012 
(C) 2012 Alison Elizabeth Jennifer McQueen 


\title{
POLITICAL REALISM IN APOCALYPTIC TIMES
}

\author{
Alison Elizabeth Jennifer McQueen, Ph. D.
}

Cornell University 2012

This dissertation traces the responses of three canonical political realists-Niccolò Machiavelli, Thomas Hobbes, and Hans Morgenthau — to eruptions of apocalyptic rhetoric, imagery, and politics. I treat apocalypticism as a very particular kind of utopianism that is premised on a belief in the imminent end of the known world and the arrival of a radically new future. Contemporary realists tend to position their pragmatic approaches to politics against 'utopian' alternatives, which they reject for being at best unrealizable and at worst profoundly dangerous. However, in tracing the historical engagement between political realism and apocalypticism, I find a more complex and productive relationship. Through an historical and textual analysis of the work of Machiavelli, Hobbes, and Morgenthau, I argue that much of the nuance and texture in these realists' work, and particularly their evolving conceptions of human nature and their commitments to political action, emerge from serious and extended engagements with apocalypticism. 


\title{
BIOGRAPHICAL SKETCH
}

\begin{abstract}
Alison McQueen was born in Toronto, Ontario, Canada. She completed her secondary education at the Linden School in Toronto. She received her BA (with distinction) in International Development from the University of Guelph in 2003, her MA in Political Science and International Relations from the University of Toronto in 2005, and her $\mathrm{PhD}$ in Government from Cornell University in 2012. She is an Assistant Professor in the Department of Political Science at Stanford University.
\end{abstract}


For my parents,

David McQueen and

Nancy McQueen,

and in memory of my aunt,

Jennifer McQueen 


\section{ACKNOWLEDGMENTS}

As is the case with any piece of scholarship, this dissertation was in many ways a collective endeavor. It originally took shape as a loose series of observations about Machiavelli and Hobbes. Susan Buck-Morss first encouraged me to think about extending these observations to Morgenthau, pushing me in a more ambitious and exciting direction. In her capacity as the chair of my dissertation committee, Susan consistently helped me to see the project with new eyes, to find the strange in the familiar, and to take seriously the way in which images do important political theoretical work. Peter Katzenstein brought his sharp critical eye and wideranging intellect to every part of this project. And, as he has done for so many, Peter modeled what it means to be a serious and generous scholar and teacher. It was in a class with John Najemy that I first began to formulate my ideas on Machiavelli and the reading I offer in this dissertation owes much to these early conversations, as well as to John's own wonderful work on Machiavelli and Renaissance Florence. The dissertation as a whole has also benefited from John's rare combination of a breadth of vision and an eye for detail. I must acknowledge a special debt to Jason Frank. Had it not been for several seminars and many conversations with Jason, I would not have realized that I was a political theorist. He consistently saw more in this project than I knew was there. When I would turn to Jason in frustration, he would send me back to the dissertation with a renewed sense of enthusiasm. One could not ask for more.

Isaac Kramnick read early drafts of the Hobbes and Machiavelli chapters and generously agreed to read the entire dissertation in his capacity as external reader. Beyond his valuable feedback on the dissertation, I am grateful for having had the opportunity to be a teaching assistant for numerous offerings of Isaac's introductory political thought course. It is from him that I learned how one does the history of political thought. 
Many other people read and commented on one or more chapters of this dissertation. They include: Dwight Allman, Richard Bensel, Peter Breiner, Allen Carlson, Matthew Evangelista, Giovanni Giorgini, Joshua Goldstein, Benjamin Gregg, Randal Hendrickson, Al Martinich, and Travis Smith. Each of the core chapters of the dissertation was presented at a colloquium, workshop, or conference. I would like to thank the organizers and audiences at Cornell's Political Theory Workshop and Dissertation Colloquia, the University of Texas at Austin, and at the annual meetings of the American Political Science Association, the Association for Political Theory, the Canadian Political Science Association, and the Midwest Political Science Association. This project received financial support from the Social Sciences and Humanities Research Council of Canada, the Cornell School of Graduate Studies, and the Einaudi Center for International Studies.

Burke Hendrix has seen me through the highs and lows of this dissertation. At every stage, the project benefited from his encouragement, questions, and gentle requests for clarification. Most of all, however, I appreciate the many ways in which Burke helped me to see the humor in an often gloomy subject.

My greatest debt is to my parents, to whom this dissertation is dedicated. They first nurtured the skills required for scholarly work-reading, writing, and asking questions (not necessarily in that order). My aunt Jennifer, who died during the final stages of this project, supported and encouraged me throughout my graduate work. She was proof that it is possible to be a compassionate realist. 


\section{TABLE OF CONTENTS}

1 Introduction 1

2 Theorizing Apocalypse: Context to Concept 24

3 Niccolò Machiavelli’s Savonarolan Moment 77

4 Thomas Hobbes: "Feigning the World to be Annihilated" 127

$5 \quad$ Hans Morgenthau and the Postwar Apocalyptic Imaginary 187

6 Conclusion: On the Art of Living Through Catastrophe 242

Bibliography 253 


\section{LIST OF FIGURES}

$1 \quad$ Botticelli, Mystic Nativity (1500-1) 95

2 Botticelli, Crucifixion (1497-8) 96

$3 \quad$ Luca Signorelli, Apocalypse Sequence (1499-1502) 98

$4 \quad$ Luca Signorelli, Apocalypse Sequence (1499-1502) 99

$5 \quad$ 'C' Illustration, John Foxe's Acts and Monuments (1653) 134

$6 \quad$ Frontispiece, Thomas Hobbes’ Leviathan (1651) 176

$7 \quad$ Anthony Van Dyck, King Charles I (ca. 1635) 179

$8 \quad$ Anthony Van Dyck, Charles I, King of England (1636) 180

$9 \quad$ Anthony Van Dyck, Christ Healing the Paralytic (1619) 181

10 Gislebertus, The Last Judgment (1130-1135) 182 


\section{CHAPTER ONE}

\section{INTRODUCTION}

[W] hen we get to May 21 on the calendar in any city or country in the world, and the clock says about - this is based on other verses in the Bible - when the clock says about 6 p.m., there's going to be this tremendous earthquake that's going to make the last earthquake in Japan seem like nothing in comparison. And the whole world will be alerted that Judgment Day has begun.

Harold Camping, Interview, May 11, 2011

For a half a century, America defended our own freedom by standing watch on distant borders. After the shipwreck of communism came years of relative quiet, years of repose, years of sabbatical. And then there came a day of fire... By our efforts we have lit a fire as well-a fire in the minds of men. It warms those who feel its power; it burns those who fight its progress. And one day this untamed fire of freedom will reach the darkest corners of our world.

President George W. Bush,

Second Inaugural Address, 2005

[T]he evidence coming in from the watchers around the world brings news of an imminent shift in our climate towards one that could easily be described as Hell: so hot, so deadly that only a handful of the teeming billions now alive will survive.

James Lovelock, The Revenge of Gaia: Earth's Climate Crisis and the Fate of Humanity, 2006

In the months and days leading up to May 21, 2011, civil engineer turned radio evangelist Harold Camping preached an apocalyptic message of hope and despair. A cross-country billboard campaign urged Americans to "Save the Date!" and announced the "Return of Christ. May 21, 2011." On this day, the faithful would be taken up to heaven in the rapture. From the safety of their heavenly perches, they would look down as a wave of divine destruction wrapped its way around the globe, consuming the world and massacring the unfaithful. Fires, wars, and plagues of the kinds described in the book of Revelation would ravage the earth for five months, 
killing millions each day. With these predictions, Camping offered his followers a vision of the apocalypse - the imminent end of the known world and the beginning of a radically new future. When May 21 came and went without incident, Camping and his followers, some of who had quit their jobs and disposed of their assets, were widely ridiculed. ${ }^{1}$ Behind much of this ridicule was a sense that Camping and his followers were exactly what many of us expect an apocalyptic group to be-marginal, religious, and ultimately wrong.

These preconceptions are often reinforced by media portrayals of apocalyptic groups. Many of us imagine a band of vulnerable people who, under the direction of a charismatic false prophet, have gathered in a rural bunker to await the imminent end of the known world. We imagine groups who have chosen to cut themselves off from mainstream society and to pursue their apocalyptic expectations to a violent consummation. Some of the most prominent cases of apocalyptic belief seem to fit this mold. For instance, the mass suicide of more than 900 members of the Peoples Temple at Jonestown, Guyana in 1978 was motivated in part by this group's apocalyptic expectations. The Branch Davidians, a group of whom were involved in a protracted armed standoff with the FBI outside of Waco, Texas in 1993, were similarly motivated by expectations of an imminent end. Four years later, 39 members of Heaven's Gate, a group that combined elements of Christian apocalypticism with beliefs about the salvation of the soul through UFO transport, committed mass suicide. Neither these beliefs nor their dangerous consequences are exclusively American or Western. In 1995, members of Aum Shinrikyo, a Japanese group whose beliefs combine elements drawn from yoga, Buddhism, and Christian apocalypticism, released Sarin gas on the Tokyo subway system, killing 13 people and

\footnotetext{
${ }^{1}$ Jesse McKinley, "Despite Careful Calculations, the World Does Not End," New York Times, May 21, 2011, accessed July 7, 2011, http://www.nytimes.com/2011/05/22/us/22doomsday.html ; Jesse McKinley, "An Autumn Date for the Apocalypse," New York Times, May 23, 2011, accessed July 7, 2011, http://www.nytimes.com/2011/05/24/us/24rapture.html.
} 
severely injuring many others. While these movements ultimately caused far more destruction of life and property than Camping's May 21 group, they all serve to reinforce our preconceptions about apocalyptic groups. In each case, followers were motivated by charismatic leaders espousing beliefs about the imminent end that are difficult for most outsiders to understand, let alone accept as action-guiding principles.

Yet, as will become clear in the course of this dissertation, apocalyptic beliefs are not exclusively or even primarily held by members of socially marginal groups. They are regularly embraced by those in the highest positions of political power. Consider George W. Bush's presidential rhetoric in the aftermath of the terrorist attacks of September 11, 2001, a sample of which appears in the epigram above. While it is stripped of overt biblical imagery and addresses a much broader audience than Camping's predictions, Bush's remarks nonetheless offer a similarly apocalyptic narrative. Harold Camping and his followers had expected that May 21 would be the end of time and the cataclysmic birth of a new world. In its invocation of a "day of fire," Bush's statement also marks a rupture in the temporal continuity of history. The attacks herald a new world in which different rules of state practice apply and previously unacceptable forms of state violence may be necessary to win a war against "evil." Like Camping, Bush evinces a certainty about the course of history. The "untamed fire of freedom" will spread to the "darkest corners of the world." It will burn "those who fight its progress." Camping called upon his followers to put their trust in God's plan for history. May 21 would mark the beginning of a terrifying battle between good and evil that would inaugurate a new and better world. In his 2003 State of the Union Address, Bush asked Americans for a similar act of faith: "We Americans have faith in ourselves, but not in ourselves alone. We do not...claim to know all the ways of Providence, yet we can trust in them, placing our confidence in the loving God behind 
all life and all history." ${ }^{2}$ While the September 11 attacks might have initially raised questions about the progressive direction of history, Bush's apocalyptic narrative absorbs the attacks, casting them as the terrifying birth pangs of a new world. ${ }^{3}$

Bush is not the only American president to situate contemporary events in an apocalyptic narrative. While he was governor of California, Ronald Reagan confided to a political associate that the recent coup in Libya was "a sign that the day of Armageddon isn't far off." While Reagan downplayed these beliefs when he became President, his Secretary of Defense Caspar Weinberger was more forthright: "I have read the Book of Revelation and yes, I believe the world is going to end — by an act of God, I hope — but every day I think that time is running out." ${ }^{\prime 4}$ Bush's apocalyptic rhetoric is therefore by no means unique. Where it differs from Reagan and Weinberger's statements is primarily in its capacity to convey its apocalyptic message more selectively. For Christians familiar with the book of Revelation, or other biblical accounts of world-consuming disaster, the images of fire connote both apocalyptic catastrophe and the final purification of humanity. For others, this imagery simply serves as a secular metaphor for disaster and renewal. There is a similar multivocality in Bush's speech announcing the beginning of United States military strikes against Al Qaeda and the Taliban in Afghanistan. Bush admitted that "initially, the terrorists may burrow deeper into caves and other entrenched hiding places." But American military action would soon "drive them out and bring them to justice." ${ }^{5}$ To non-Christian audiences, these images might not have carried any special

\footnotetext{
${ }^{2}$ George W. Bush, State of the Union Address (January 28, 2003), accessed July 20, 2011, http://www.presidency.ucsb.edu/ws/index.php?pid=29645\#axzz1UZTKZP00

3 Antoine Bousquet, "Time Zero: Hiroshima, September 11 and Apocalyptic Revelations in Historical Consciousness," Millennium: Journal of International Studies 34, no. 3 (2006): 761.

${ }^{4}$ As quoted in Paul Boyer, When Time Shall be No More: Prophecy Belief in Modern American Culture (Cambridge: Harvard University Press, 1992), 142, 141.

${ }^{5}$ George W. Bush, Address to the Nation Announcing Strikes Against Al Qaida Training Camps and Taliban Military Installations in Afghanistan (October 7, 2001), accessed July 20, 2011, http://www.presidency.ucsb.edu/mediaplay.php?id=65088\&admin=43
} 
meaning, beyond the familiar promise that American military power would be both effective and decisive. To certain Christian audiences, however, the statement might well have evoked the culmination of God's wrath described in the book of Revelation:

Then the kings of the earth and the magnates and the generals and the rich and the powerful, and everyone, slave and free, hid in the caves and among the rocks of the mountains, calling to the mountains and rocks, 'Fall on us and hide us from the face of the one seated on the throne and from the wrath of the Lamb [Jesus]; for the great day of their wrath has come, and who is able to stand? ${ }^{6}$

The Christian apocalyptic undertones of Bush's speeches are there for those able and willing to hear them.

Even if we admit that apocalyptic beliefs can be held by the marginal and the powerful alike, Bush's rhetoric still seems to confirm the popular perception that these beliefs are primarily religious, and perhaps especially Christian, in character. Yet consider the statement by environmentalist James Lovelock quoted in the third epigraph. Lovelock uses the religious imagery of hell to describe an entirely secular apocalypse - an end to the world brought about not by divine but by human agency. He is certainly not alone in characterizing climate change in apocalyptic terms. After showing some particularly devastating images of natural disasters in $A n$ Inconvenient Truth, former Vice President Al Gore notes that they are "like a nature hike through the book of Revelations [sic]." Lovelock and Gore, no less than Camping and Bush, have apocalyptic beliefs about the end of the world. But, one might object, surely there is a difference between religious beliefs about the apocalypse and secular expectations of the end of the world. Today's environmentalists, like the anti-nuclear activists of the Cold War, are not describing some fantastical apocalypse outlined in the Bible and transposed into the contemporary world. They are talking about the real apocalypse—an impending end supported by hard facts and data. The polar ice caps are melting. Rates of extreme weather events are on the rise. Yet as we shall

\footnotetext{
${ }^{6}$ Revelation 6:15-17 (NRSV).
} 
see, the terrors that were nourished by the Christian apocalypticism of fifteenth-century Florence and seventeenth-century England were real enough for those who experienced them. Believers looked around them and saw signs of an impending end that seemed every bit as incontrovertible as evidence of environmental doom is today. ${ }^{7}$ Whether they are held by the marginal or the powerful, whether they are overtly religious or seemingly secular, apocalyptic beliefs share an expectation of an imminent end to the known world and the arrival of a radically new future.

\section{Political Realism in Apocalyptic Times}

This dissertation arose from a suspicion that such beliefs have had a more pervasive and important influence on the history of modern political thought than is generally supposed. The more I learned about the historical circumstances in which several canonical political thinkers wrote, the more I became convinced that apocalypticism was a missing part of the contextual stories that we use to make sense of their work. All three of the thinkers covered in this dissertation-Niccolò Machiavelli (1469-1527), Thomas Hobbes (1588-1679), and Hans Morgenthau (1904-1980) — wrote during times in which powerful political, social, and religious actors thought that the end of the world was imminent. Machiavelli wrote in the context of Dominican friar Girolamo Savonarola's disturbing apocalyptic visions about the future of Florence. While Savonarola was executed in 1498, the apocalypticism that he was so influential in shaping would continue to haunt Florentine and Italian life well into the sixteenth century. Thomas Hobbes developed his political thought against the backdrop of both Puritan and Royalist attempts to cast the English Civil War in apocalyptic terms. This apocalypticism persisted during the Protectorate as apocalyptic ideas were deployed both by and against Oliver

\footnotetext{
${ }^{7}$ Frank Kermode makes a similar point in a comparison of fears of nuclear annihilation and older forms of apocalyptic expectation. See: Frank Kermode, The Sense of an Ending: Studies in the Theory of Fiction with a New Epilogue (Oxford: Oxford University Press, 2000), 182-3.
} 
Cromwell. Working much later, Hans Morgenthau wrote his most influential works on international politics in the aftermath of the Holocaust and in the shadow of the atomic bomb and the looming threat of nuclear annihilation. Yet with a few notable exceptions, the importance of these apocalyptic contexts has remained profoundly underexplored in the secondary literature on these thinkers. ${ }^{8}$

The question motivating this project is: How does our understanding of the political thought of Machiavelli, Hobbes, and Morgenthau change when we consider the apocalyptic contexts in which they wrote? What I hope to demonstrate is that an attention to the apocalyptic contexts in which these three thinkers wrote does two things. First, it allows us to make sense of aspects of their work that have been largely ignored in the history of political thought. For instance, the final two books of Hobbes' Leviathan tend to receive scant attention by scholars of the history of political thought. ${ }^{9}$ These are chapters in which Hobbes engages in detailed theological arguments that, at first blush, seem largely unconnected to the political arguments outlined in the first two books of the work. However, as I hope to show in Chapter 4, these theological arguments are central to Hobbes' political project. In them, he does battle with the antinomian apocalypticism of the English Civil War and attempts to make radical Christian eschatology safe for sovereign power. Second, an attention to the apocalyptic context in which these thinkers wrote serves to cast some of the most familiar parts of their work in a new light. For example, seen alongside the Savonarolan rhetoric that shaped Florentine politics in the late

\footnotetext{
${ }^{8}$ J.G.A. Pocock has given apocalyptic beliefs some treatment in his work on Machiavelli and Hobbes. See: J.G.A. Pocock, The Machiavellian Moment: Florentine Political Thought and the Atlantic Republican Tradition, $2^{\text {nd }}$ edition (Princeton: Princeton University Press, 2003), 83-113; J.G.A. Pocock, "Time, History and Eschatology in the Thought of Thomas Hobbes," in The Diversity of History: Essays in honour of Sir Herbert Butterfield, eds. J.H. Elliott and H.G. Koenigsberger (Ithaca: Cornell University Press, 1970), 149-98.

${ }^{9}$ Pocock wryly notes: "The two books in which Hobbes expounds Christian faith and its sacred history are almost exactly equal in length to Books I and II [of Leviathan]; yet the attitude of too many scholars towards them has traditionally been, first, that they aren't really there, second, that Hobbes didn't really mean them." See: Pocock, "Time, History and Eschatology," 161-2.
} 
fifteenth century, the final chapter of Machiavelli's Prince begins to look less like a strategic ploy to curry favor with the Medici and more like an apocalyptic exhortation of despair and hope.

To find any kind of sustained attention to apocalyptic ideas in the works of Machiavelli, Hobbes, and Morgenthau is surprising. These three thinkers are generally classed as political realists..$^{10}$ That is, they are classed as part of a tradition which stresses a pragmatic approach to a political world marked by the competition for material interests and the struggle for power. Political realists insist on the profound limits to human and institutional perfectibility and therefore position their approaches to politics against utopian alternatives, which they reject for being at best unrealizable and at worst profoundly dangerous. For instance, Hobbes' conception of humans as competitive and fearful creatures seems to provide little hope for perfectionist schemes. The best we can hope for is a kind of terrifying political order under the rule of an absolute sovereign capable of holding us in awe. ${ }^{11}$ For Machiavelli and Morgenthau, however, utopian schemes are not just unattainable; they are also unwise. Machiavelli famously contrasts his approach in The Prince to that of those who imagine "republics and principalities that have never been seen or known to exist in truth; for it is so far from how one lives to how one should

\footnotetext{
${ }^{10}$ While Machiavelli and Hobbes do not self-identify as political realists, contemporary realists and students of realism tend to look back on these earlier thinkers as intellectual predecessors. See, for example: Steven Forde, "Varieties of Realism: Thucydides and Machiavelli," The Journal of Politics 54 (1992): 372-393; David Boucher, Political Theories of International Relations: From Thucydides to the Present (Oxford: Oxford University Press, 1998), 90-167; Thomas L. Pangle and Peter J. Ahrensdorf, Justice Among Nations: On the Moral Basis of Power and Peace (Lawrence: University Press of Kansas, 1999), 125-61; Jack Donnelly, Realism and International Relations (Cambridge: Cambridge University Press, 2000), 13-5, 24-6; Michael C. Williams, The Realist Tradition and the Limits of International Relations (Cambridge: Cambridge University Press, 2005), 19-51. Hans Morgenthau self-identifies as a political realist. However, scholars like William Scheuerman and Michael Williams have questioned and sought to complicate this identification. See: Williams, The Realist Tradition, 82-127; William E. Scheuerman, Hans Morgenthau: Realism and Beyond (Cambridge: Polity, 2009), 1-10; William E. Scheuerman, "Was Morgenthau a Realist? Revisiting Scientific Man Vs. Power Politics," Constellations 14, no. 4 (2007): 50630 .

${ }^{11}$ However, as I argue in Chapter 4, Hobbes' account of the transition from the state of nature to the Leviathan state rests on a utopian hope that humanity can be transformed such that they can prioritize the fear of bodily death over the fear of eternal torment.
} 
live that he who lets go of what is done for what should be done learns his ruin rather than his preservation."12 Morgenthau draws a similar distinction between the possible and the desirable:

Political realism is aware of the moral significance of political action. It is also aware of the ineluctable tension between the moral command and the requirements of successful political action. And it is unwilling to gloss over and obliterate that tension and thus to obfuscate both the moral and the political issue by making it appear as though the stark facts of politics were morally more satisfying than they actually are, and the moral law less exacting than it actually is. $^{13}$

For both Machiavelli and Morgenthau, utopian thinking lures us away from the contextual and contingent realities of politics, making prudential and effective action impossible.

The secondary literature, particularly in International Relations theory, reinforces this conception of the tradition by casting political realism as a successor to, a critique of, or even the opposite of idealism or utopianism. ${ }^{14}$ If we treat apocalypticism as a particular kind of utopianism premised on a belief in the imminent end of the known world and the arrival of a radically new future, the literature outlined above suggests that we should expect that political realists would limit themselves to critiquing or even simply dismissing apocalyptic expectations. Instead, as I outline below and in more detail in the course of the dissertation, Machiavelli,

\footnotetext{
${ }^{12}$ Niccolò Machiavelli, The Prince, trans. Harvey C. Mansfield (Chicago: University of Chicago Press, 1998), ch. 15,61 .

${ }^{13}$ Hans J. Morgenthau, Politics Among Nations: The Struggle for Power and Peace, $2^{\text {nd }}$ edn. (New York: Alfred A. Knopf, 1954), 9.

${ }^{14}$ See, respectively: John Vasquez, The Power of Power Politics: From Classical Realism to Neotraditionalism (Cambridge: Cambridge University Press, 1998), 36; Stefano Guzzini, Realism in International Relations and International Political Economy: The continuing story of a death foretold (London and New York: Routledge, 1998), 16; Robert Gilpin, "The Richness of the Tradition of Political Realism," in Neorealism and its Critics, ed. Robert O. Keohane (New York: Columbia University Press, 1986), 304. These kinds of characterizations are a testament to the enduring influence of E.H. Carr on International Relations theory. Carr's The Twenty Years' Crisis identifies realism as both a successor to utopian idealism in the study of International Relations and as an intellectual disposition and political stance that is always a reaction to perfectionist projects. These two understandings of the relationship between realism and utopianism involve different timelines. In the context of disciplinary history, utopianism is an infantile stage in the study of International Relations and consists of a relatively static set of commitments - a misguided and inferior understanding of international politics that will eventually be overtaken by a more scientific and detached realism. In the context of the intellectual and political landscape in which international politics are practiced, utopianism is a persistent and recurrent human tendency, constantly in need of being checked by a skeptical realism. See: Tim Dunne, "Theories as Weapons: E.H. Carr and International Relations," in E.H. Carr: A Critical Appraisal, ed. Michael Cox (Houndsmills: Palgrave, 2000), 222.
} 
Hobbes, and Morgenthau pursue sustained and troubled engagements with apocalypticism in ways that are ultimately transformative of these thinkers' realism. In the case of Machiavelli and the early Morgenthau, the confrontation with apocalypticism prompts constitutive aspects of these thinkers' realism to take shape. For example, as I will argue in more detail in Chapter 3, several constitutive features of Machiavelli's realism — its attention to the ease with which virtue becomes vice, its emphasis on enduring limits to political action, and its insistence on the impossibility of putting a settled end to conflict—only arise after an initial flirtation with apocalypticism. In the case of Hobbes and the later Morgenthau, attempts to co-opt and redeploy apocalyptic rhetoric and imagery cause these thinkers to abandon key realist tenets. In their redeployments, both thinkers use frightening apocalyptic scenarios to legitimize dangerously utopian schemes. For Hobbes, it is the submersion of individual wills into the single will of the sovereign, while for Morgenthau is the submersion of separate and diverse states into a powerful world state. None of these realist responses merely reject apocalypticism. Rather, they take seriously the dangers and possibilities of apocalyptic rhetoric and imagery.

The literature on apocalypticism offers similar reasons to be surprised upon finding a sustained and ambivalent engagement with fears and hopes about the end of the world in the realist tradition. Histories of apocalypticism tend to divide their subjects into two groups: apocalypticists and anti-apocalypticists. This tendency is on full display in Heaven on Earth (2001), the most recent work by Richard Landes, a prominent millennial historian. Landes makes a clear division between apocalyptic "roosters" who announce the imminent end of the world and anti-apocalyptic "owls" whose conservative feathers are ruffled by these radical proclamations. As "roosters" await the coming cataclysm, "owls" advise caution "and counsel 
against hasty enthusiasms." 15 While Landes' conceptual binary admits some variation within categories, it does not allow for any kind of complexity across them. Many other scholars of apocalypticism implicitly affirm this binary, which leads to difficulties in classifying thinkers who seem neither wholly apocalyptic nor entirely anti-apocalyptic. For instance, St. Augustine, who as we shall see in Chapter 2 attempts to negotiate the dangers of apocalypticism while never fully disavowing expectations about the end times, is frequently classed as an anti-apocalyptic thinker. ${ }^{16}$ Given the complexity of Augustine's response and his commitment to central elements of the Christian apocalyptic narrative, such a classification hardly seems to do him justice. The easy binary of apocalypticism vs. anti-apocalypticism subjects us to what Stephen Holmes, in another context, calls the "tyranny of false polarities"17 —a stylized and misleading antithesis that prevents an accurate account of the range of responses to fears and hopes about the end of the world. Given the two mutually exclusive options, one would have to class political realists as anti-apocalyptic "owls." Their insistence on the limits to human perfectibility and the inescapability of conflict would seem to make realists profoundly hostile to expectations of radical world transformation. However, as we shall see in the course of this dissertation, the realist response to apocalypticism renders any kind of easy classification impossible. Like Augustine, Machiavelli, Hobbes, and Morgenthau, are drawn to elements of the apocalyptic narrative at the same time as they attempt to negotiate its dangers.

\footnotetext{
${ }^{15}$ Richard Landes, Heaven on Earth: The Varieties of the Millennial Experience (Oxford: Oxford University Press, 2011), 47.

${ }^{16}$ See, for instance: Stephen D. O'Leary, Arguing the Apocalypse: A Theory of Millennial Rhetoric (Oxford: Oxford University Press, 1994), 73-6; Bernard McGinn, Visions of the End: Apocalyptic Traditions in the Middle Ages (New York: Columbia University Press, 1979), 26. For more nuanced treatments, see: Paula Fredriksen, "Apocalypse and Redemption in Early Christianity: From John of Patmos to Augustine of Hippo," Vigiliae Christianae 45, no. 2 (1991): 160-8; R.A. Markus, Saeculum: History and Society in the Theology of St. Augustine (Cambridge: Cambridge University Press, 1970), esp. 1-71.

${ }^{17}$ Stephen Holmes, Passions and Constraints: On the Theory of Liberal Democracy (Chicago: University of Chicago Press, 1995), 28.
} 
More specifically, I argue that much of the nuance and texture, as well as some of the contradictions and inconsistencies in Machiavelli, Hobbes, and Morgenthau's work emerge from their serious and extended engagements with apocalypticism. In an analysis of their work and the political and religious contexts in which they were writing, I find responses to apocalypticism that are far more complex than mere opposition or dismissal. These responses take two forms. The first is a principled turn away from apocalypticism and toward a tragic worldview that (a) emphasizes the ease with which virtuous actions can produce terrible consequences, (b) insists on the limits to effective political action, and (c) warns of the impossibility of final and enduring political settlements. This is the response adopted by Machiavelli in his later work and by Morgenthau in his earlier work. In Machiavelli's case, this response encourages the development and maturation of his realist thought. The second approach attempts to redeploy apocalypticism by calling on people to imagine the end of the world in order to prevent it. This is the tack taken by Hobbes in order to make his case for the Leviathan state and by Morgenthau in his later writings on nuclear weapons. For both Hobbes and the later Morgenthau, this attempt to respond to apocalypticism by redeploying it puts pressure on central aspects of these thinkers' realism and provides them with the imaginative tools necessary to legitimize dangerous utopian schemes.

\section{Approach}

In both its subject and approach, this project sits at the intersection of the history of political thought, the history of International Relations thought, and political theology. The advantages of this intersectional approach will, I hope, become clear in the course of the dissertation. For the purposes of this introduction, however, it is worth noting that the approach 
has two primary benefits. First, the political theological approach, which I outline in more detail below, is attentive to the way in which religious modes of thought underpin seemingly secular political discourses. This project does not begin with the assumption, commonly held in both the history of political thought and International Relations theory, that the three thinkers covered here are unambiguously "secular." 18 Once this assumption is relaxed, the richness of Machiavelli, Hobbes, and Morgenthau's investigations of theological themes and imagery comes into focus. Second, this intersectional approach makes it possible to trace the intellectual trajectories and recurrent dilemmas of a tradition that has its roots in the canonical works in the history of Western political thought but whose contemporary proponents tend, with a few notable exceptions, to be scholars of international politics. While contemporary scholars of International Relations tend to look back to the works of Machiavelli, Hobbes, and Morgenthau as classic articulations of a political realist tradition that continues to exercise considerable influence over the field, they are generally content to leave detailed investigations of the first two thinkers to political theorists. For their part, political theorists have largely left the analysis of Morgenthau's thought to their colleagues in International Relations. ${ }^{19}$ Working across the boundaries between these two fields, this project aims to bring these thinkers and their field-specific literatures into productive conversation.

Beyond pursuing an argument about the importance of apocalypticism to realist thought, one of my secondary goals of this project is to make the case to political theorists that Hans Morgenthau is a thinker worthy of further attention. Primarily known as a pre-eminent postwar

\footnotetext{
${ }^{18}$ Leo Strauss, for example, points to both Machiavelli and Hobbes as harbingers of a secular and ultimately corrosive modernity. The works of both thinkers stem from "the concern with a right or sound order of society whose actualization is probable, if not certain, or does not depend on chance. Accordingly, they deliberately lower the goal of politics." See: Leo Strauss, Natural Right and History, (Chicago: University of Chicago Press, 1953), 191.

${ }^{19}$ For an important and illuminating exception, see: Scheuerman, Hans Morgenthau.
} 
scholar of International Relations, he left a lasting imprint on this field, particularly in the United

States, where he is seen as both a forerunner and an intellectual antipode to later and more "scientific" realists like Kenneth Waltz. However, Morgenthau's intellectual lineage and connections are far more complex and interesting than this conventional account suggests. Like University of Chicago colleagues and fellow German Jewish émigré scholars Leo Strauss and Hannah Arendt, Morgenthau's early intellectual development took place in Weimar Germany. During these early years, he was profoundly influenced by both Friedrich Nietzsche and Max Weber and their work would leave a lasting imprint on his own long after he had established himself as a prominent scholar of International Relations in America. ${ }^{20}$ Like Strauss and Arendt, Morgenthau situates his thoroughgoing critique of liberalism within a grand narrative of modern decline. Yet, also like them, he evinces a profound admiration for some of the founding values and practices of his adopted country. ${ }^{21}$ Even if the lines of direct intellectual influence are sometimes hard to trace, Morgenthau acknowledges the important impact that both Strauss and Arendt had on some of his most well known works. ${ }^{22}$

Like his two Chicago colleagues, Morgenthau also had a long-standing and troubled intellectual relationship with the Weimar jurist Carl Schmitt. I outline many of these connections in detail in Chapter 5. For our purposes here, it is simply worth noting that the ties

\footnotetext{
${ }^{20}$ On the influence of Nietzsche, see: Christoph Frei, Hans J. Morgenthau: An Intellectual Biography (Baton Rouge: Louisiana State University Press, 2001), 93-113.

${ }^{21}$ See, for instance: Hans J. Morgenthau, The Purpose of American Politics (New York: Vintage, 1964), 3-42; Hans J. Morgenthau and David Hein, Essays on Lincoln's Faith and Politics, ed. Kenneth W. Thompson (Lanham: University Press of America, 1983), 1-101.

${ }^{22}$ In the preface to the second edition of Politics Among Nations (1960), Morgenthau thanks Strauss for his comments on the work's new first chapter which contains the now-famous "Six Principles of Political Realism." This acknowledgement is especially interesting, given Strauss' hostility to some of the foundational principles of political realism, as well as his dismissive attitude toward theories of international politics. Robert Myers reports that Strauss "commented that he saw no more need for a theory of international relations than for a theory of plumbing." See: Robert J. Myers, U.S. Foreign Policy in the Twenty-First Century: The Relevance of Realism (Baton Rouge: Louisiana State University Press, 1999), 11. When asked to name the ten books that had had the greatest intellectual influence on him, Morgenthau included Arendt's The Human Condition, alongside works by Plato, Aristotle, Publius, and Nietzsche. See: Frei, Hans J. Morgenthau, 113.
} 
between the two thinkers went in both directions, almost always without any direct attribution. Morgenthau's critique of the first edition of Schmitt's Concept of the Political (1927) prompted important revisions, while Schmitt's theories of sovereignty and the exception shaped Morgenthau's postwar realism. ${ }^{23}$ Finally, during the course of his career, Morgenthau struck up intellectual connections and correspondences with a surprisingly varied array of thinkers, including Reinhold Niebuhr, Karl Jaspers, and Michael Oakeshott. ${ }^{24}$ While the detailed pursuit of these conversations is beyond the scope of this project, my hope is that they at least begin to make the case for Morgenthau as an important political thinker in his own right, as well as one who is fruitfully considered alongside Machiavelli and Hobbes.

My approach to the three thinkers covered in this dissertation is broadly contextualist. Because contextual research in the history of political thought for the last forty years has been dominated by a set of methodological commitments first articulated by Quentin Skinner, it may be helpful to explain where my approach differs from his. Like Skinner, I begin with the assumption that "the text itself" is not "the self-sufficient object of inquiry and understanding.," 25 For instance, it beggars the imagination that one could come to a full and complete understanding of Hobbes' detailed theological investigations in the last two books of Leviathan without some understanding of the biblical texts to which he is referring as well as to the ways in which these texts were taken up in the political and religious debates of seventeenth-century England. I further share Skinner's assumption that the study of a text requires detailed attention

${ }^{23}$ See: William E. Scheuerman, "Carl Schmitt and Hans Morgenthau: Realism and beyond," in Realism Reconsidered: The Legacy of Hans Morgenthau in International Relations, ed. Michael C. Williams (Oxford: Oxford University Press, 2007), 92; Scheuerman, Hans Morgenthau, 32-9, 44-50; Nicolas Guilhot, "American Katechon: When Political Theology Became International Relations Theory," Constellations 17, no. 2 (2010): 22453.

${ }^{24}$ On Morgenthau and Niebuhr, see: Daniel Rice, "Reinhold Niebuhr and Hans Morgenthau: A Friendship with Contrasting Shades of Realism," Journal of American Studies 42, no.2 (2008), 255-91. On Morgenthau and Jaspers, see: Scheuerman, Hans Morgenthau, 146-52. On Morgenthau and Oakeshott, see: Nicholas Rengger, "Tragedy of Scepticism? Defending the Anti-Pelagian Mind in World Politics," International Relations 19, no. 3 (2005): 321-8.

${ }^{25}$ Quentin Skinner, "Meaning and Understanding in the History of Ideas," History and Theory 8, no. 1 (1969): 4. 
to the historical context in which it was produced, and particularly the range of meanings available to the author. Texts should not be treated as the abstract thoughts of politically detached philosophers, but as political speech acts designed to generate effects in the reader.

However, I depart from Skinner and his followers on three counts. First, Skinner calls on historians of political thought to embark on a program of research that is at best very ambitious and at worst simply unachievable. He explains: "the appropriate methodology for the history of ideas must be concerned, first of all, to delineate the whole range of communications which could have been conventionally performed on the given occasion by the utterance, and, next, to trace the relations between the given utterance and this wider linguistic context as a means of decoding the actual intention of the given writer." 26 Putting aside questions of feasibility, I think there is much to be gained from a more selective and focused account of certain elements of an author's context. This seems especially true when those elements have been neglected in previous contextual scholarship. This is the kind of more targeted contextualism that I attempt in this project. In its focus on the largely underexplored apocalyptic contexts in which the three chosen thinkers wrote, this dissertation provides a way in which to understand those aspects of these thinkers' work that have remained somewhat strange to contemporary readers, like Hobbes' troubled musings on hell and damnation or Machiavelli's observations about the eternity of the world. However, it also helps to make some of their most familiar passages strange once again. For instance, Machiavelli's exhortation at the end of The Prince and Morgenthau's critique of liberal internationalism in Scientific Man vs. Power Politics look very different when reconsidered in light of the apocalyptic fears and hopes that shaped the politics of their respective times.

\footnotetext{
${ }^{26}$ Skinner, "Meaning and Understanding," 49. Emphasis mine.
} 
Second, Skinner adopts a hardline position on the question of whether there are traditions of political thought in which authors are engaged in similar and recurrent debates through time. He draws upon the work of R.G. Collingwood who argues that philosophers are not concerned with a finite set of permanent questions to which thinkers of different eras have given particular answers that can easily be compared. Rather, "what is thought to be a permanent problem $\mathrm{P}$ is really a number of transitory problems $\mathrm{p}_{1}, \mathrm{p}_{2}, \mathrm{p}_{3} \ldots$ whose individual peculiarities are blurred by the historical myopia of the person who lumps them together under the one name P." 27 Following Collingwood, Skinner argues that the questions with which thinkers are concerned transform themselves in subtle ways over time. While there is a valuable warning here about the dangers of building artificial intellectual "traditions" around seemingly perennial questions, I think that both the concern and its methodological implications are overstated. In writing of $a$ realist "tradition," I do not intend to reify the "tradition" by claiming an intellectual unity that does not actually exist. Drawing on the work of Michael Williams, the position underlying my approach is that traditions are necessarily constructed "both internally by those who see themselves engaged in a common project, or working through and against a common intellectual background; and externally by those who seek to provide insights via a synthetic representation of individual positions. ${ }^{28}$ I do not intend to claim that there are no substantial differences across or within the thought of Machiavelli, Hobbes, and Morgenthau. Nor do I intend to suggest that the three thinkers are always engaged with the same issues and problems or that they frame those issues and problems in the same way through time. However, I do think that three thinkers share certain fundamental similarities - like an attention to the inescapable role of power in politics, a

\footnotetext{
${ }^{27}$ R.G. Collingwood, An Autobiography (Oxford: Oxford University Press, 1978 [1939]), 69. See also: Quentin Skinner, "The rise of, challenge to and prospects for a Collingwoodian approach to the history of political thought," in Dario Castiglione and Iain Hampsher-Monk (eds.) The History of Political Thought in National Context (Cambridge: Cambridge University Press, 2001), 175-188.

${ }^{28}$ Williams, The Realist Tradition, 16.
} 
concern with the limits of human perfectibility, and a resistance to abstract or utopian political schemes - that provide sufficient resonances across their respective works to plausibly group them together as political realists.

Finally, Skinner's approach is almost exclusively focused on the textual context in which a given author wrote. To be fair, he interprets the concept of a "text" far more broadly than many historians of political thought, whose analyses tend to center on canonical works. Skinner and his followers frequently engage in painstaking and detailed research of pamphlets, newspapers, letters, and manuscripts from the eras in which their chosen thinkers wrote. However, if we take seriously the possibility that authors are political actors trying not only to persuade their readers but also to capture their imaginations, we cannot limit our contextual research to texts. The images circulating in a given time would have also provided a means through which political thinkers and audiences made sense of their world. For instance, when Morgenthau attempts to describe the effects of nuclear annihilation, he evokes the images of German concentration camps that circulated after the Second World War. A narrowly textual approach to context would miss this. At several places in the dissertation, I draw on images in addition to texts in offering a contextual picture. In sum, the contextual approach that I adopt here is strategically selective, open to the resonances between thinkers through time, and not strictly textual.

In addition to its broad contextualism, the approach taken in this dissertation is also informed by political theology. Carl Schmitt offers the classic articulation of the political theological argument:

All significant concepts of the modern theory of the state are secularized theological concepts not only because of their historical development-in which they were transferred from theology to the theory of the state, whereby, for example, the omnipotent God became the omnipotent lawgiver-but also because of their 
systematic structure, the recognition of which is necessary for a sociological consideration of these concepts. The exception in jurisprudence is analogous to the miracle in theology. ${ }^{29}$

Schmitt's argument poses a fundamental challenge to established narratives of the history of political thought, which characterize "modernity" (whose origin is generally traced to the Renaissance or the Enlightenment) as a wholly secular period in which religion has been successfully contained by its relocation to the private sphere. ${ }^{30}$ For Schmitt, this means that a political-theological approach is necessarily genealogical. It is aimed at exposing "the remnants of belief that are attached to our political concepts and maintained in our political practices. The only way to do that is by tracing the theological origins of these beliefs." ${ }^{\text {31 }}$ Part of the work of this dissertation is also genealogical in this sense. The project traces the theological origins of apocalyptic contexts, narratives, and images that remain central to the work of two thinkers commonly seen as harbingers of secular modernity-Machiavelli and Hobbes. Furthermore, in examining the work of Hans Morgenthau, it explores the ways in which seemingly secular ideologies like liberalism may be underpinned by an eschatological faith.

\footnotetext{
${ }^{29}$ Carl Schmitt, Political Theology: Four Chapters on the Concept of Sovereignty, trans. George Schwab (Chicago: University of Chicago Press, 1985), 36. This intertwining of the political and theological is central to Schmitt's intellectual and political project. For Schmitt, there is an affinity between the theological and the political that emerges from their common expression as law and their shared alienation from liberalism. See: Carl Schmitt, The Crisis of Parliamentary Democracy, trans. Ellen Kennedy (Cambridge: MIT Press, 1988), 39-50; Carl Schmitt Schmitt, The Concept of the Apolitical, trans. George Schwab (New Brunswick: Rutgers, 1976), 69-79; Michael Hollerich, "Carl Schmitt," in The Blackwell Companion to Political Theology, eds. Peter Scott and William T. Cavanaugh (Malden: Blackwell, 2004), 112.

${ }^{30}$ Charles Taylor offers such a conception of modernity when he argues that modern science overtook the religious worldview that had prevailed before the "modern" era. Taylor is right that after the Reformation the legitimate foundation of government was stripped of much of its (overt) religious content. However, as a critical review of Taylor's work has noted, he "hasn't grasped the extent to which religious - and, more specifically, Christian -ideas underpin the secular era he describes. The European Enlightenment may have been hostile to Christianity, but a Christian framework still informed the view of history adopted by those Enlightenment thinkers campaigning for universal human emancipation." For the review, see: John Gray, "Faith in Reason: Secular Fantasies of a Godless Age," Harper's 316, no. 1892 (2008): 86. For Taylor's work, see: Charles Taylor, A Secular Age (Cambridge: Harvard University Press, 2007).

${ }^{31}$ Paul W. Kahn, Four New Chapters on the Concept of Sovereignty (New York: Columbia University Press, 2011), 106.
} 
However, Schmitt's political-theological argument also suggests another related methodological approach. He argues that with secularization, the ways in which divine authority was understood and negotiated were transferred to the confrontation with political sovereignty. What remains constant, however, is the "systemic structure" of the theological concept — the way in which it orders and imagines authority. The "omnipotent God" is translated into "the omnipotent lawgiver," but the structure of the concept remains the same. The connection between theology and secular political ideologies is therefore analogical. The sovereign's relationship to his subjects is like God's relationship to humanity. ${ }^{32}$ Whether or not one accepts Schmitt's argument about the precise circumstances of secularization, his methodological suggestion remains useful insofar as it points to a way of recognizing the persistence of theological concepts in secular thought and ideology. When tracing the trajectories of apocalyptic ideas in the work of modern secular thinkers, for instance, one should not limit oneself to the overtly theological expressions of these ideas. As I suggest in the following chapter, such limits would fail to do justice to the enduring flexibility of apocalyptic beliefs, their capacity to adapt to and endure in contexts radically different from those in which they were first developed. Rather, one must look for the generic structural features of apocalypticism — the way in which it organizes the relationships between time and space, earth and cosmos, and humanity and the supernatural. These structural features are outlined in greater detail in the concluding pages of the following chapter, which offers an analysis of the theological roots of apocalypticism in the Judeo-Christian tradition before abstracting from this account the basic structural features of these beliefs. This move allows us to recognize the powerful secular versions of apocalypticism at play in the work of Machiavelli, Hobbes, and Morgenthau and

\footnotetext{
${ }^{32}$ I am indebted to Lucas Thompson's (yet) unpublished work for helping me to think through Schmitt's political theology as method. My remarks here draw on his analysis.
} 
thereby trace an element of their thinking that has remained profoundly underexplored in the history of political and International Relations thought.

\section{Plan}

The argument of this dissertation unfolds in five parts. Chapter 2 reviews the outlines of the Judeo-Christian accounts of the apocalypse, with a particular focus how on they responded to concrete political contexts. Seen in this light, it is clear that these texts offer a radical critique of sovereign power, provide a powerful historical narrative in which seemingly contingent political events could be rendered meaningful, and hold out the hope for a world without conflict or difference. The chapter then considers how Paul of Tarsus and Augustine of Hippo, two early Christian thinkers who would come to be seen as the intellectual kin of later political realists, negotiate the dangers and possibilities of apocalypticism. I find in their work prototypical examples of the kinds of responses that will later be used by Machiavelli, Hobbes, and Morgenthau. I conclude with an effort to conceptualize apocalypticism not as a text or a worldview, but as an imaginary that permeates not only aesthetic and rhetorical practices but also shapes the way in which people envision their political existence. I outline the generic structural features of the apocalyptic imaginary and provide examples of how that imaginary has instantiated itself at different historical moments.

Chapter 3 situates Niccolò Machiavelli's work in the context of the apocalyptic excitement that gripped Florence in the late fifteenth century. The Dominican friar Girolamo Savonarola was at the center of this enthusiastic movement. I argue that Machiavelli's work bears the mark of this context. The final chapter of The Prince, I suggest, is an apocalyptic exhortation that resonates strongly with the Savonarolan message. Machiavelli gravitates toward 
this apocalyptic solution in The Prince because he has failed to grapple adequately with the contingency of the political world and with the particular crises that plague Florence. Recognizing the dangers inherent in such a solution, he later turns away from an apocalyptic mode and embraces a robustly tragic sensibility characterized by openness to the variability and struggle of the political world. Yet even Machiavelli's tragic turn is haunted by an eschatological hope for a perpetual republic that would offer a final escape from politics.

In Chapter 4, I locate Thomas Hobbes' political thought in the explosion of apocalyptic prophecy in the late sixteenth and seventeenth centuries, and particularly during the English Civil War. I argue that the radical apocalyptic imaginary let loose during the civil war was a central concern in Hobbes' political thought. While Christian eschatology had initially been deployed as a legitimating tool by kings and church authorities, the apocalyptic imaginary escaped this effort at sovereign control and was suddenly abroad in the land. Hobbes responds to this threat not by condemning the apocalyptic imaginary, but by trying to put it back in the service of sovereign power. He fights apocalypse with apocalypse. I argue that Hobbes pursues two paths in his project—one that is overtly Christian and another that is seemingly secular. His theological argument offers a de-radicalized Christian eschatology in which the sovereign is the only authority capable of announcing the apocalypse. Hobbes' political argument stages a secular apocalypse, in which the terror and chaos of the state of nature are the preconditions for a kingdom ruled by a mortal God. In pursuing these two paths, Hobbes does not escape the apocalyptic imaginary, but rather redeploys it and tries to return it safely into sovereign hands.

Chapter 5 sets Hans Morgenthau's work in the context of the apocalyptic imaginary that developed in postwar America. The development of nuclear weapons and the possibility of large-scale human annihilation fueled both overtly religious and seemingly secular forms of the 
apocalyptic imaginary, both of which saw an opportunity for salvation in the prospect of nuclear war. Concerned primarily with the secular apocalypticism that underpins strains of liberalism and rationalism, Morgenthau initially offers a tragic response that, like Machiavelli's turn to tragedy, emphasizes the ongoing and undecided struggle that shapes political life. However, I argue that Morgenthau later rejects this tragic response, turning instead to the Hobbesian strategy of fighting apocalypse with apocalypse. Through a close reading of his remarkable essay on "Death in the Nuclear Age," I map Morgenthau's attempt to fight the possibility of nuclear annihilation by staging an imagined apocalypse of his own. A tragic worldview, Morgenthau concludes, is not enough. One must constantly imagine the apocalypse in order to prevent it. In the concluding chapter of the dissertation, I revisit these responses to the apocalyptic imaginary and offer an evaluation of them on normative and imaginative grounds. 


\section{CHAPTER TWO}

\section{THEORIZING APOCALYPSE: CONTEXT TO CONCEPT}

After describing the catastrophic upheavals and divine judgment that will mark the end of the world, the book of Revelation concludes with a warning to anyone who would alter the final book of the Christian bible. This warning has not been heeded. For, as philosopher and theologian Jacques Ellul wonders, how is it possible to "write or preach on its subject without changing this Revelation?" " The book of Revelation has inspired sermons, theological investigations, and scholarly interpretations since the controversial decision to canonize it. If Ellul's intuition is right, then the book itself has been transformed by these efforts. The idea of "apocalypse" has undergone a similar process of transformation. While its literal meaning is simply "revelation," it has come to describe anything from the cataclysmic end of the world prophesied in the bible to the effects of nuclear war or global climate change to the more mundane inconveniences of severe winter storms. ${ }^{2}$ The idea of apocalypse is thus flexible, migratory, and unstable. It resists the kind of conceptualization that would render its content narrowly specifiable and its behavioral effects easily predictable. This chapter attempts no such endeavor. Instead, it aims to theorize apocalypse in a way that attends both to its contextually specific roots in the Judeo-Christian tradition and to its ability to transcend these origins and occupy a central place in the modern Western imagination. ${ }^{3}$ This kind of theorization involves treating apocalyptic texts as political works that make visible existing power relations at the same time as they offer the radical hope of overcoming them. However, it also means going

\footnotetext{
${ }^{1}$ Jacques Ellul, Apocalypse: The Book of Revelation, trans. George W. Schreiner (New York: The Seabury Press, 1997), 9 .

${ }^{2}$ The severe winter storm that hit the mid-Atlantic states in early February 2010 was widely dubbed the "Snowpocalypse."

${ }^{3}$ While this chapter, and indeed the dissertation, focuses on a Western tradition of apocalypticism, the phenomenon itself is not exclusively Western. In addition, the label "Western" is used with some caution. What most scholars class as "Jewish," "Christian," or "Western" apocalypticism traces its roots back to "non-Western" sources like Persian and Near Eastern mythology.
} 
beyond the textual sources of apocalypticism in the Judeo-Christian tradition and offering a structural conception of the apocalypse that allows us to recognize it even when it persists in forms that are very different from these original articulations. This contextual and conceptual theorization provides the necessary groundwork for understanding both the overtly theological outbursts of apocalypticism in Machiavelli and Hobbes' historical periods and the more secular manifestations of apocalyptic rhetoric and imagery to which Morgenthau was responding.

The chapter proceeds in three parts. First, it offers a contextual and political reading of the two canonical apocalyptic texts of the Judeo-Christian tradition-the books of Daniel and Revelation. I begin here because, taken together, these works are the textual locus of Western apocalypticism and the origin of themes and images that have endured in contexts far different from those in which they were originally conceived. In examining Daniel and Revelation, I draw heavily on historical and critical biblical scholarship. However, the general approach taken is similar to that in the rest of the dissertation. It locates these works within their historical contexts and highlights the ways in which they imagine and respond to concrete political developments. Second, the chapter examines two early Christian attempts by Paul of Tarsus and Augustine of Hippo to contain the antinomian potential of these apocalyptic texts. While they are interesting in themselves, these containment attempts have a larger significance for this dissertation, as Paul and Augustine are the two foundational figures of a Christian strand of political realism. This section identifies responses to apocalypticism that will later be deployed by Niccolò Machiavelli, Thomas Hobbes, and Hans Morgenthau in their respective times. Finally, the third section of the chapter expands on a latent intuition in Paul and Augustine's work - that the power and potential danger of apocalypticism lie in its capacity to captivate the imagination. This section explores what it might mean to theorize the apocalypse not as a genre of literature, or even a worldview, 
but as an imaginary. This final section moves beyond the historical source material covered earlier to construct a theoretical account of the apocalypse that attends both to its enduring structural features and the way it in which its narrative and images provide a shared away of envisioning our common world.

\section{The Judeo-Christian Apocalypse}

Let us begin conservatively in the safe ground of etymology. The word "apocalypse" comes from the Greek apokalypsis, meaning "revelation," "disclosure," or "uncovering." The book of Revelation identifies itself as "the apokalypsis of Jesus Christ," marking the first known use of the term to denote a literary genre. ${ }^{4}$ In this sense, an apocalypse is a species of eschatology, a teaching about the "last things." In its concern with the end of history, eschatology is primarily focused on the communal and cosmic fate of the world, rather than on the ultimate fate of the individual..$^{5}$ While apocalypses partake of this communal and cosmic orientation, they bring a sense of urgency and imminence to the end of history that is not a necessary feature of eschatology. ${ }^{6}$ Thus, while all apocalypses are eschatological, not all eschatology is apocalyptic. Biblical scholars also typically draw another distinction between apocalypticism, a worldview or "symbolic universe," and apocalypse, a literary genre. ${ }^{7}$ In what

\footnotetext{
${ }^{4}$ Paul D. Hanson, “Apocalypses and Apocalypticism: The Genre," in The Anchor Bible Dictionary, vol. 1, ed. David Noel Freedman (New York: Doubleday, 1992), 279.

${ }^{5}$ David L. Petersen, "Eschatology," in The Anchor Bible Dictionary, vol. 2, ed. David Noel Freedman (New York: Doubleday, 1992), 576. Some theologians and biblical scholars refer to a personal or individual eschatology. However, the dominant usage refers to a communal fate and I will adhere to this usage in the dissertation.

${ }^{6}$ As Bernard McGinn notes: "Every Christian view of history is in some sense eschatological insofar as it sees history as a teleological process and believes that Scripture reveals truths about its End...But there is still an important difference between a general consciousness of living in the last age of history and a conviction that the last age itself is about to end." See: Bernard McGinn, Visions of the End: Apocalyptic Traditions in the Middle Ages (New York: Columbia University Press, 1998), 4.

7 John J. Collins, "Apocalypses and Apocalypticism: Early Jewish Apocalypticism," in The Anchor Bible Dictionary, vol. 1, ed. David Noel Freedman (New York: Doubleday, 1992), 283. There is some debate among Biblical scholars regarding the content of "apocalypticism", much of which hinges on how we understand the concept of a worldview. John Collins understands apocalypticism as a "symbolic universe," while Paul Hanson
} 
follows, I outline the origins and features of an apocalyptic worldview, as conceptualized in the biblical studies scholarship, before embarking on a more detailed consideration of the genre of apocalyptic literature and the political contexts to which it responds.

The apocalyptic worldview took shape gradually in response to the political crises that plagued ancient Palestine. This is worth stressing. The origins of the apocalyptic worldview do not lie "outside" of politics in the realms of revelation and theology. Rather, they are inescapably political. At the dawn of the Christian era, Palestine had suffered eight centuries of conflict and almost perpetual foreign domination. The inhabitants of the northern Kingdom of Israel and the southern Kingdom of Judah endured conquest, exile, foreign rule, and pressures for cultural assimilation. Perhaps the worst blows came when the Assyrians destroyed the northern kingdom in $722 \mathrm{BCE}$ and the Babylonians captured the southern kingdom in $586 \mathrm{BCE}$. Along with the loss of political sovereignty, both conquests led to substantial deportations of Jews from their homeland. Only in the case of the Babylonian exile was return to this land allowed at all. These political circumstances raised difficult questions among ancient Jews, who believed that they had entered into a covenant with God in which he would offer them protection in exchange for their adherence to his law. Why had God not leapt to Israel's defense? Why was he failing to uphold his side of the covenant? Ancient prophets like Amos, Hosea, and Isaiah in the eighth century $\mathrm{BCE}$ and Jeremiah and Ezekiel in the sixth century BCE argued that Israel's sufferings were of her own making. The people had fallen away from God and were no

argues for a more detailed definition of apocalypticism as "the symbolic universe in which an apocalyptic movement codifies its identity and interpretation of reality." Collins rightly notes that the problem with this more precise conceptualization is that "there is no automatic connection between apocalypticism and social movements. In many cases we know very little of the social matrix in which apocalyptic literature was produced." See: Paul D. Hanson, "Apocalypticism," in Interpreter's Dictionary of the Bible, Supplementary Volume, eds. Keith Crim, et al. (Nashville: Abington Press, 1976), 30; Collins, "Early Jewish Apocalypticism," 284. 
longer devoted to keeping his law. If they returned to him, their sufferings would end and their political sovereignty would be restored. ${ }^{8}$

Over time, this position proved difficult to maintain. Suffering seemed to befall those who obeyed God's law just as much as it did those who had strayed. Furthermore, during the reign of Antiochus IV Epiphanes (175-164 BCE), those Jews who were most pious and observant were the special targets of political persecution. The rise of the phenomenon of Jewish martyrdom raised new questions. Why would God punish those who had kept his law in the face of overwhelming political and cultural pressure to abandon it? The apocalyptic worldview developed, in part, as an answer to this question. ${ }^{9}$ Bart Ehrman summarizes the outlines of this answer as follows:

God was still in control of this world in some ultimate sense, but for unknown and mysterious reasons he had temporarily relinquished his control to the forces of evil that opposed him. This state of affairs, however, was not to last forever. Quite soon, God would reassert himself and bring this world back to himself, destroying the forces of evil and establishing his people as rulers over the earth. When this new Kingdom came, God would fulfill his promises to his people. ${ }^{10}$

The apocalyptic worldview is thus a form of political theodicy—an attempt to understand the oppression and loss of sovereignty that plagued the Israelites without delegitimizing the authority

\footnotetext{
${ }^{8}$ Bart D. Ehrman, Jesus: Apocalyptic Prophet of the New Millennium (New York: Oxford University Press, 1999), 120. The relationship between prophetic and apocalyptic worldviews is more complex and contested than the simple narrative I have presented in this paragraph and the following one suggests. For more detailed studies that capture some of the scholarly debate on this issue, see: Paul D. Hanson, The Dawn of Apocalyptic: The Historical and Sociological Roots of Jewish Apocalyptic Eschatology (Philadelphia: Fortress Press, 1975); John J. Collins, The Apocalyptic Imagination: An Introduction to Jewish Apocalyptic Literature, $2^{\text {nd }}$ edn. (Grand Rapids: William B. Eerdmans, 1998); John J. Collins, "From Prophecy to Apocalypticism: The Expectation of the End," in The Continuum History of Apocalypticism, eds. Bernard J. McGinn, John J. Collins, and Stephen J. Stein (New York: Continuum, 2003), 64-88.

${ }^{9}$ While the political circumstances outlined here go some way to explaining why we see the rise of a fully developed apocalyptic worldview by the second century BCE, the ideational and mythological roots of this worldview can be traced, in part, to ancient Near Eastern myth and Persian eschatology. The extent and nature of these influences are contested among biblical scholars. See: Richard J. Clifford, "The Roots of Apocalypticism in Near Eastern Myth," in The Continuum History of Apocalypticism, eds. Bernard J. McGinn, John J. Collins, and Stephen J. Stein (New York: Continuum, 2003), 3-29; Anders Hultgård, "Persian Apocalypticism," in Continuum History of Apocalypticism, 30-63.

${ }^{10}$ Ehrman, Jesus, 120-1.
} 
of God. More broadly, it is an attempt to situate contemporary political circumstances within a sacred worldview, thereby endowing them with religious significance. We find evidence for this worldview in the book of Daniel, discussed below, the Dead Sea Scrolls from the Essenes in Qumran, various non-canonical Jewish writings from the second century BCE through the end of the first century CE.

While there is some disagreement among biblical scholars about the content of the apocalyptic worldview, most agree that it has the following features. First, it embraces a cosmic dualism. Worldly reality is defined by the conflict between good and evil forces. The former are a small minority, while the latter are an overwhelming majority. God and his angels are aligned on the side of good, light, and life. His cosmic adversary, Satan or the Devil, and his demons are aligned on the side of evil, darkness, and death. For those on earth, neutrality is impossible. One stands either with the divine forces of good or with the demonic forces of evil. ${ }^{11}$ Second, this cosmic dualism corresponds to an historical dualism. Time is divided into two eras - the present age and the promised future. ${ }^{12}$ The present era is dominated by the forces of evil, which cause the good to suffer through war, famine, and death. For mysterious reasons of his own, God has ceded control over history to evil powers. However, he will soon irrupt into the world, bringing time to a close, annihilating the forces of evil, and reestablishing his sovereignty over the earth. ${ }^{13}$ Third, the apocalyptic worldview is marked by a pessimistic historical determinism. Supernatural agents control the direction of human affairs. ${ }^{14}$ The prophesied end will happen

\footnotetext{
${ }^{11}$ Ehrman, Jesus, 121.

${ }^{12}$ This historical dualism becomes more complicated in the Christian tradition. Some early Christians saw the resurrection of Jesus as the beginning of the prophesied end of the world. However, the Kingdom of God had clearly not yet been established. It would come only with the parousia, or Jesus' return to earth, which many saw as imminent. Thus, some early Christians saw themselves as living in a kind of "middle time" between the resurrection and the parousia. Through the resurrection of Jesus, the future eschatological age had already begun to impinge upon the present. This is clearest in Paul's writings. See: 1 Cor. 15:23-4; 1 Thess. 1:10.

${ }^{13}$ Ehrman, Jesus, 121.

${ }^{14}$ Collins, "From Prophecy to Apocalypticism," 85.
} 
independent of human agency. ${ }^{15}$ Even worse, the forces of good will continue to be the particular targets of persecution and oppression until God intervenes to decisively reassert his sovereignty over the world. ${ }^{16}$ Fourth, this "denouement of history" will culminate in a final act of divine redemption and universal vindication. ${ }^{17}$ God will annihilate the forces of evil and effect a cosmic transformation, resulting in a new heaven and new earth. He will then preside over a day of universal judgment, rewarding the faithful with membership in his kingdom and condemning the wicked to eternal damnation. ${ }^{18}$ Finally, the apocalyptic worldview is characterized by a sense of urgency and imminence. The "triple drama of crisis-judgmentvindication" will happen very soon. ${ }^{19}$ Those with an apocalyptic worldview see themselves as living at the edge of time. Any day now, they will witness the closure of history and the dawn of a new world order.

Not all apocalypticists wrote apocalypses. For instance, there is a strong case to be made that Jesus shared the apocalyptic worldview outlined above, even though he did not write any apocalyptic works. ${ }^{20}$ Nevertheless, this worldview finds its strongest voice in the genre of

\footnotetext{
${ }^{15}$ It is worth emphasizing the crucial distinction between classical Jewish prophecy and apocalypticism. Despite their disturbing predictions of divine wrath, prophets like Jeremiah do not see the future as closed or determined. They urge Israel to return to God precisely because they think that human choices affect the direction of history. The apocalyptic worldview, on the other hand, assumes that the future is written. Human actions cannot change the course of history. An individual may repent, return to God, and join the forces of good. But, in so doing, he is only taking steps to ensure his own salvation. He cannot, either acting individually or in concert with others, prevent or avoid the coming crisis, judgment, and vindication.

${ }^{16}$ Ehrman, Jesus, 121-2.

${ }^{17}$ Collins, "From Prophecy to Apocalypticism," 85.

${ }^{18}$ Ehrman, Jesus, 122.

${ }^{19}$ The quoted phrase is from: Bernard McGinn, "Revelation," in The Literary Guide to the Bible, eds. Robert Alter and Frank Kermode (Cambridge: The Belknap Press of Harvard University Press, 1990), 526.

${ }^{20}$ For instance, Mark reports the following statement: "But in those days, after the suffering, the sun will be darkened, and the moon will not give its light, and the stars will be falling from heaven, and the powers in the heavens will be shaken. Then they will see the Son of Man coming in clouds with great power and glory. Then he will send out the angels, and gather his elect from the four winds, from the ends of the earth to the ends of heaven...So, when you see these things taking place, you know that he is near, at the very gates. Truly I tell you, this generation will not pass away until all these things have taken place" (Mark: 13:24-30, NRSV). See also: Mark 8:38-9:1; Matt. 13:40-43. The apocalyptic interpretation of Jesus' teachings was popularized in academic circles by Albert Schweitzer's The Quest of the Historical Jesus (1906). More recently, a version of this reading has been taken up by Bart Ehrman in Jesus: Apocalyptic Prophet of the New Millennium (1999). John Dominic Crossan
} 
apocalyptic literature. While biblical scholars disagree on the generic features of an apocalypse, the following abstract definition is often taken as a solid starting point: “'Apocalypse' is a genre of revelatory literature with a narrative framework, in which a revelation is mediated by an otherworldly being to a human recipient, disclosing a transcendent reality which is both temporal, insofar as it envisages eschatological salvation, and spatial insofar as it involves another, supernatural world." ${ }^{21}$ This definition draws attention to both the form of apocalyptic literature (e.g. its narrative structure) and its content (e.g. otherworldly mediator). John J. Collins, the chair of the group of scholars that crafted the definition, has since offered an important clarification. While the definition implies that all apocalypses have both a temporal and a spatial dimension, Collins has since suggested that most apocalyptic literature emphasizes one over the other. We can therefore divide apocalypses into at least two fairly distinct groups. Otherworldly journeys are vertical and spatial. They explore the relationship between the earthly and heavenly realms. An angelic being gives a human protagonist a tour of heaven, illuminating the supernatural sources of earthly reality. The first portion of the non-canonical book of Enoch, for example, is an otherworldly journey. This form is also central to various strains of mysticism and some well-known works of literature, like Dante's Divine Comedy. Historical apocalypses, on the other hand, are horizontal and temporal. They sketch the direction of history. A human protagonist receives a highly symbolic revelation about the future course of events, the meaning of which is often explained by some kind of supernatural interpreter. The second half of the

offers a forceful argument that Jesus did not have a Jewish apocalyptic worldview. This argument rests on an assertion that the sources in the gospels are not the earliest writings on the life of Jesus and that a more accurate picture of his life can be found in even earlier extra-testamentary materials. This argument runs into problems because its dating of these non-canonical gospels is highly speculative. See: John Dominic Crossan, Jesus: A Revolutionary Biography (San Francisco: Harper San Francisco, 1994).

${ }^{21}$ John J. Collins, “Apocalypse: Towards the Morphology of a Genre," Semeia 14 (1979), 9. This definition incorporates input from a group of scholars in the Apocalypse Group of the Society of Biblical Literature's Genres Project. 
book of Daniel and the entirety of the book of Revelation are historical apocalypses. ${ }^{22}$ Apocalypses of this type are the primary textual source for the religious apocalyptic movements to which Machiavelli and Hobbes are responding.

The two most developed and historically influential biblical apocalypses are in the books of Daniel and Revelation, which display most of the features of the apocalyptic genre and all of the elements of the apocalyptic worldview outlined above. In what follows, I offer brief summaries of the context, structure, and contents of each book, followed by some observations about their political relevance. Any account of works of this kind of complexity and symbolic density necessarily resorts to some simplification. The discussion I offer below imposes some artificial coherence on texts that are often frustratingly elaborate and obscure. Furthermore, it does not aim to be exhaustive, but rather to draw out some of the structural characteristics, images, and political themes that persist in later manifestations of apocalyptic expectation, and particularly during the historical periods in which Machiavelli, Hobbes, and Morgenthau wrote.

The book of Daniel contains the only fully developed apocalypse in the Hebrew bible. The nature and status of the book are subject to some debate in the Judeo-Christian tradition. In the Hebrew bible, Daniel is placed among the Kethuvim (Writings), reflecting the late date of its composition and perhaps also a sense that it should not be accorded the status given to the Prophets. ${ }^{23}$ Christians, on the other hand, have been eager to assign the book a more prominent place, situating it among the Prophets in their bible. The reason for this enhanced status is that

\footnotetext{
${ }^{22}$ Collins, "Early Jewish Apocalypticism," 283; Collins, "From Prophecy to Apocalypticism," $77 . \quad$ The vertical/horizontal distinction is from: McGinn, "Revelation," 526.

${ }^{23}$ This may have been a determination based purely on considerations of genre. Daniel is not identified as a prophet anywhere in the book. However, it may also have reflected a discomfort within the rabbinic tradition of the place that Daniel occupied in the Christian tradition, particularly the early church's tendency to see "prefigurations of Christ and Christian resurrection" in the book. Also, as Lawrence M. Wills explains, "Jewish tradition was sometimes critical of what appeared to be a positive relationship between Daniel and Nebuchadnezzar." See: Lawrence M. Wills, "Daniel Introduction and Annotations," in The Jewish Study Bible, Tanakh Translation, eds. Adele Berlin and Mark Zvi Brettler (New York: Oxford University Press, 2004), 1642.
} 
the book of Daniel has had an important impact on the development of several elements of Christian doctrine. First, it is the only text in the Hebrew bible that offers an unambiguous reference to bodily resurrection and judgment after death, a belief that is central to the Christian tradition. ${ }^{24}$ Second, it is the source of the figure identified as "one like the son of man," a cosmic judge who descends to earth on the clouds. ${ }^{25}$ Early christologies see Jesus himself in this role. Finally, as we shall see below, several of the other images and symbols in Daniel, and particularly those that describe earthly kingdoms as beasts, are further developed in the book of Revelation.

The book of Daniel is pseudonymous and recounts the heroic exploits and revelatory visions of its eponymous protagonist. The text includes two distinct genres. Chapters 1-6 are "court legends" narrated in the third person and recount Daniel's heroic exploits in the courts of foreign rulers. In this portion of the book, Daniel is an interpreter of the dreams and visions of others. Chapters 7-12, which are narrated in the first person, describe a series of symbolic visions and are fully apocalyptic. ${ }^{26}$ Here, Daniel is himself a visionary, the recipient of revelations about the end times. While the reader is told that Daniel lived during the time of the Babylonian Exile, critical biblical scholars agree that the book was composed and compiled much later. There is substantial agreement that the apocalyptic part of Daniel was written sometime between 167 and $164 \mathrm{BCE}^{27}$ This dating suggests a very particular historical context.

\footnotetext{
${ }^{24}$ Isa. 26:19 ("Your dead shall live, their corpses shall rise") and Hos. 6:2 ("After two days he will revive us; on the third day he will raise us up, that we may live before him") seem to suggest a resurrection. However, as John J. Collins notes, they "are more probably speaking metaphorically of the restoration of the Israelite people." See: John J. Collins, "Daniel, Book of," in The Anchor Bible Dictionary, vol. 2, ed. David Noel Freedman (New York: Doubleday, 1992), 35.

${ }^{25}$ Dan. 13:7.

${ }^{26}$ The interpretive difficulties posed by the change of genre are compounded by the fact that Daniel 1:1-2:4a, 8-12 are in Hebrew, while Daniel 2:4b-7:28 are in Aramaic. These linguistic shifts do not coincide with the genre division. For a summary of scholarly attempts to deal with bilingual nature of the text, see: Collins, "Daniel," 31 .

${ }^{27}$ This dating is unusually precise. Contemporary critical scholars tend to accept the case that was first made by the third-century philosopher Porphyry, whose argument (which survives only in the form of a citation in Jerome), was
} 
In $175 \mathrm{BCE}$, Antiochus IV Epiphanes succeeded his brother as ruler of the Seleucid Empire. In two military campaigns financed through taxes levied on Judea and the pillage of the Temple at Jerusalem, Antiochus attempted to wrest control of Egypt from the Ptolemies before threats from Rome forced his withdrawal. Upon his return, he strengthened an existing program of cultural and religious assimilation. With the support of some Hellenized Jews, Antiochus systematically outlawed Jewish religious practices and began a campaign of violent persecution aimed at ensuring the hegemony of Greek culture and institutions. For many faithful Jews, the final straw came in 167 BCE when Antiochus installed a statue of Zeus in the Temple in Jerusalem. The stage had been set for a guerrilla campaign that would later become known as the Maccabean Revolt. ${ }^{28}$ It is within the context of these policies of cultural assimilation and persecution that the apocalyptic message of Daniel took shape.

While the summary provided here focuses on the apocalyptic half of Daniel (chapters 712), there is a story in the early portion of the book that is essential for understanding this later material. Chapter 2 recounts an incident during Daniel's time in the court of the Babylonian king Nebuchadnezzar. The king has had a troubling dream and summons his interpreters, commanding them to tell him both the content of the dream and its meaning, on pain of violent death. Unsurprisingly, the interpreters find this task impossible. Facing the threat of imminent execution, Daniel prays to God and the mystery of the dream is revealed. Daniel recounts the dream to the king: "there was a great statue... its brilliance extraordinary; it was standing before you and its appearance was frightening. The head... was of fine gold, its chest and arms of silver,

that the book of Daniel was accurate in its predictions up to but not beyond the reign of Antiochus IV Epiphanes (r. 175-164 BCE). The book is also especially detailed in its descriptions of the persecution of Jews between 167 and $164 \mathrm{BCE}$, which suggests that this was a matter of particular (and likely contemporary) concern. See: Collins, The Apocalyptic Imagination, 87-8.

${ }^{28}$ Much of the summary given here comes from the (admittedly one-sided) account in 1 and 2 Macc. For an attempt to evaluate existing arguments about Antiochus' motives and to develop a new position on the issue, see: Erich S. Gruen, "Hellenism and Persecution: Antiochus IV and the Jews," in Hellenistic History and Culture, ed. Peter Green (Berkeley and Los Angeles: University of California Press, 1993), 238-264. 
its middle and thighs of bronze, its legs of iron, its feet partly of iron and partly of clay." 29 A stone cut "not by human hands" struck the statue, breaking it in pieces and leaving it "like chaff of the summer threshing floors." 30 In its place, the stone grew into "a great mountain and filled the whole earth."31 Daniel explains that the head of gold represents the Babylonian kingdom, while the other materials are three consecutive kingdoms of decreasing strength. The stone is the eternal kingdom of God that "shall crush all these kingdoms and bring them to an end."32 Untroubled by the coming destruction of his kingdom, the grateful Nebuchadnezzar rewards the interpreter and acknowledges the sovereignty of Daniel's God. Here, the destruction of earthly kingdoms and the establishment of the kingdom of God is an event that will occur in the distant future. There are still three kingdoms to come after Babylon's demise.

In contrast, the second half of the book is marked by an unmistakable sense of apocalyptic urgency. Chapters 7 through 12 describe Daniel's visions of a future that would have been imminent for those living under Antiochus IV Epiphanes in the second century BCE. Chapter 7 revisits the theme of the four kingdoms in a vision that Daniel is reported to have had during the reign of "King Belshazzar."33 This time, the kingdoms are portrayed symbolically as a series of beasts rising out of the sea, each more frightening than the last. The fourth beast emerges with ten horns, three of which are then uprooted to make room for a smaller, arrogant horn. Then God appears in the form of an "Ancient One," takes his seat on a fiery throne, and passes judgment on the four beasts. ${ }^{34}$ Finally, "one like a son of man" descends on "the clouds of heaven" and is granted "dominion and glory and kingship" over "all peoples, nations, and

\footnotetext{
${ }^{29}$ Dan. 2:32-33.

${ }^{30}$ Dan. 2:34-35.

${ }^{31}$ Dan. 2:35.

${ }^{32}$ Dan. 2:44.

${ }^{33}$ This is one of several places in which the book of Daniel is historically inaccurate. Belshazzar was not a king. He reigned as a kind of prince regent when his father, Nabonidus, was absent.

${ }^{34}$ Dan. 7:9.
} 
languages" by the Ancient One. ${ }^{35}$ This kingdom will endure forever. An angelic figure then interprets the dream for Daniel. The four beasts represent four kingdoms. However, their power will not last and "the holy ones of the Most High shall receive the kingdom and possess the kingdom forever." ${ }^{, 36}$ He then explains that the small, arrogant horn will persecute "the holy ones of the Most High." ${ }^{37}$ This persecution will endure for three and half years, after which the horn will be subject to divine judgment and stripped of his dominion. ${ }^{38}$ To an audience living during the reign of Antiochus IV Epiphanes, the meaning of this angelic interpretation would have been clear. The four beasts are the kingdoms of Babylon, Media, Persia, and Greece, while the ten horns represent Alexander the Great's successors. ${ }^{39}$ The small, arrogant horn is Antiochus IV Epiphanes, whose persecution will usher in a day of judgment and the establishment of the kingdom of God.

Subsequent chapters develop the themes introduced in this vision. Chapter 8 offers a similar vision in which the four kingdoms are represented as animals and provides an angelic interpretation that confirms the identification of these kingdoms outlined above. Chapter 9 deals with a problem of apocalyptic chronology, reinterpreting Jeremiah's prophecy that Jerusalem would remain devastated for seventy years. Given that Jeremiah prophesied in the early sixth

\footnotetext{
${ }^{35}$ Dan. 7:13-4. The NRSV translates the Aramaic "one like a son of man" as "one like a human being." The figure of the 'Son of Man' is the subject of some debate. Here, it refers to an angelic figure that descends from heaven on clouds and presides over the eternal kingdom on earth. Non-canonical first century BCE Jewish apocalyptic works also sometimes use the designation "Son of Man" to refer to a cosmic judge who will deliver Israel. See, for example: 1 Enoch 69. However, Jesus also refers to a figure he calls "the Son of Man," who will "gather his elect from the four winds" to admit them into the kingdom of God and condemn evildoers to "the furnace of fire" (Matt. 13:40-43). Some Christians believe that Jesus is referring to himself and that the figure mentioned in Daniel actually anticipates the Second Coming of Jesus.

${ }^{36}$ Dan. 7:18.

${ }^{37}$ Dan. 7:25.

${ }^{38}$ The period of the little horn's reign is literally described as "a time, two times, and a half time." Interpreters take this to mean three and a half years, which was roughly the duration of Antiochus' persecution of the Jews. Also, as exactly half of seven (which was seen as a perfect number), three and half denoted radical incompleteness. See: Amy-Jill Levine, "Daniel Introduction and Notes," in The New Oxford Annotated Bible, New Revised Standard Version with Apocrypha, $4^{\text {th }}$ edn., ed. Michael D. Coogan (Oxford: Oxford University Press, 2010), 1249.

${ }^{39}$ This reading is confirmed by the angelic interpretation of a similar vision in the following chapter. Dan. 8:18-25.
} 
century and the later chapters of Daniel were written in the mid-second century BCE, in a time when Jerusalem remained under foreign control, some interpretive solution had to be reached. The angel Gabriel explains to Daniel that Jeremiah's message was a code intended to indicate not seventy years, but seventy weeks of years, or 490 years. ${ }^{40}$ The description of the last week of this period is a thinly veiled account of Antiochus' persecutions and his profanation of the Temple.

The vision that spans the final three chapters of the book offers an extended and detailed account of the final events of worldly history. Daniel is visited by an angelic being, with "eyes like flaming torches" and arms and legs "like the gleam of burnished bronze." ${ }^{41}$ Speaking to Daniel with a voice "like the roar of a multitude," he explains that the worldly events of the Hellenistic wars are but a reflection of a battle in heaven between angelic "princes. ${ }^{42}$ With the help of Michael, he is currently battling the prince of Persia and will soon confront the prince of Greece. Having explained the heavenly source of the Hellenistic wars, he then offers a brief summary of political history from the end of the Babylonian kingdom through to reign of Antiochus IV Epiphanes, which is the subject of a more detailed set of predictions. The angel outlines Antiochus' rise to power, his military campaigns in Egypt, and his eventual withdrawal under Roman pressure before detailing the ruler's program of persecution. Daniel is told that the ruler will abolish religious ceremonies and set up an "abomination that makes desolate," a reference to Antiochus' installation of a statue of Zeus in the Temple at Jerusalem. During these

\footnotetext{
${ }^{40}$ Other portions of Daniel also give precise date calculations of the period between Antiochus' persecutions and the end of time. In Dan. 8: 14, we are told that the Temple will remain desolate for 2300 "evenings and mornings," which amount to 1150 days. In Dan. 12:11-12, we are given two different numbers of days: "From the time that the regular burnt offering is taken away and the abomination that desolates is set up, there shall be one thousand two hundred ninety days. Happy are those who persevere and attain the thousand three hundred thirty-five days." Of the latter passage, Collins notes that "the fact that two different figures are given strongly suggests that the second calculation was added after the first number of days had passed," a phenomenon that would become quite prevalent in later apocalyptic movements. See: Collins, "From Prophecy to Apocalypticism," 76.

${ }^{41}$ Dan. 10:6.

${ }^{42}$ Dan. 10:6, 13-20.
} 
events, "the wise among the people shall give understanding to many" but will also be the particular targets of violent persecution. ${ }^{43}$ The angel then reveals (inaccurately, as it turns out) the circumstances of Antiochus' demise. The vision concludes with an account of the end of days. After the death of Antiochus, "there shall be a time of anguish, such as has never occurred since nations first came into existence." 44 There will be a bodily resurrection and "many of those who sleep in the dust of the earth shall awake, some to everlasting life, and some to shame and everlasting contempt."45 All of Daniel's people whose names are "found written in the book" will be delivered. ${ }^{46}$ The angel then advises Daniel to keep the contents of this vision secret and "the book sealed until the time of the end," warning that in the meantime "evil shall increase."47

The book of Daniel is an "imaginative construction" of the historical crisis facing second century BCE Judeans. That is, it does not simply reflect or respond to the political events of its time but also renders these events metaphorically and locates them within a sacred worldview that endows them with transcendent significance. ${ }^{48}$ For these reasons, the symbols and images that the text brings together would prove almost endlessly flexible and migratory. Less than two centuries later, they would provide some of the central imagery in the book of Revelation.

The author of this book identifies himself as "John" and tells us that he "was on the island of Patmos because of the word of God and the testimony of Jesus." ${ }^{49}$ Most scholars agree that the author of Revelation is not John, son of Zebedee, one of Jesus' disciples. ${ }^{50}$ Internal textual evidence suggests that he was an itinerant prophet in Asia Minor. He may also have been

\footnotetext{
${ }^{43}$ Dan. 11:33.

${ }^{44}$ Dan. 12:1.

${ }^{45}$ Dan. 12:2.

${ }^{46}$ Dan. 12:1.

${ }^{47}$ Dan. 12:4.

48 The notion of an "imaginative construction" is from Collins, Apocalyptic Imagination, 114.

${ }^{49}$ Rev. 1:9.

${ }^{50} \mathrm{John}$, son of Zebedee is reported to have been killed sometime before $70 \mathrm{CE}$ and most scholars think that Revelation was written or compiled in the 90s CE. In addition, the author of Revelation never identifies himself as a disciple of Jesus.
} 
of Jewish birth, perhaps even a refugee from the first Roman-Jewish War $(66-73 \mathrm{CE}) .{ }^{51}$ Most critical biblical scholars agree that the book of Revelation was written or compiled during the later part of the reign of the Roman emperor Domitian (r. 81-96 CE) and there is good internal textual evidence to support this claim. ${ }^{52}$ In contrast to the case of Antiochus IV Epiphanes, there is little evidence that Domitian made any kind of systematic effort to persecute Christians for their faith. Nevertheless, there were other political circumstances that may well have made both Jews and Christians profoundly uneasy. Barely a few decades had passed since the first JewishRoman war, which ended with the destruction of the Temple in Jerusalem in 70 CE. ${ }^{53}$ Only six years before this, Nero had embarked on a campaign of violent persecution against Christians in order to deflect blame for the great fire in Rome. ${ }^{54}$ Given the brutality and significance of both of these events, it would hardly be surprising if they continued to traumatize Christians in the mid 90s CE. A more subtle, though no less important, source of distress may have come from the imperial cult, which cast emperors and their families as gods and called upon those under Roman authority to worship them. ${ }^{55}$ The imperial cult had helped to secure the loyalties of

\footnotetext{
${ }^{51}$ John's knowledge of the Hebrew Bible and the similarities between Revelation and earlier Jewish apocalypses, like Daniel, suggest that John may well have been Jewish. The fact that he seems to have known Greek, Hebrew, and possibly Aramaic suggests that we was a native of Palestine, as there is little reason to think Jews in the Diaspora would have learned Hebrew or Aramaic. For a review of debates about authorship, see: Adela Yarbro Collins, Crisis and Catharsis: The Power of Apocalypse (Philadelphia: The Westminster Press, 1984), 24-53.

${ }^{52}$ Rome is equated with Babylon in Revelation. We find this equation in various non-canonical Jewish apocalypses from the same period, all of which indicate that the reason for this association is that Rome, like Babylon previously, destroyed the Temple and waged war on Jerusalem. This evidence suggests that Revelation was written sometime after 70 CE. See: Yarbro Collins, Crisis and Catharsis, 57-8.

${ }^{53}$ The first Roman-Jewish war began under Nero (r. 54-68) and continued under Vespasian (r. 69-79).

${ }^{54}$ Yarbro Collins, Crisis and Catharsis, 99-100. The persecution of Christians under Nero took place between 64 and 68 A.D.

${ }^{55}$ There is a lively scholarly debate about the extent to which Christians in Asia Minor should be seen as oppressed and/or persecuted. Adela Yarbro Collins, whose work I have drawn upon here, argues that some Christians were very likely still traumatized by Nero's persecutions and the first Roman-Jewish War. This trauma was compounded by the pressure to participate in the imperial cult. Elisabeth Schüssler Fiorenza argues that the oppression and colonial exploitation of Christians in Asia Minor were even more serious than Yarbro Collins suggests. Leonard Thompson, on the other hand, argues that there is little evidence of this kind of pervasive oppression and cautions that Revelation should be seen not as a reflection of the social reality in Asia Minor, but as John of Patmos' attempt to alienate his audience from their social context. See: Yarbro Collins, Crisis and Catharsis, 99-104; Elisabeth Schüssler Fiorenza, The Book of Revelation: Justice and Judgment (Philadelphia: Fortress, 1985), 126-7; Leonard
} 
provinces far from the center of the empire and was enthusiastically embraced by many people living in Asia Minor. ${ }^{56}$ Tied as it was to polytheism and the worship of political sovereigns, the imperial cult was likely very troubling to devout Christians and Jews. Even worse, one of the deified emperors who some would have been called upon to worship was Titus who, as a military commander, had laid siege to Jerusalem and destroyed the Temple. ${ }^{57}$ It is in this context that John of Patmos wrote the book of Revelation.

The text begins with John's overpowering encounter with the risen Jesus, who is identified as "one like the Son of Man." 58 In terms that echo the description of the angelic being that mediates Daniel's apocalyptic vision, Jesus is described as having eyes "like a flame of fire," feet "like burnished bronze," and a voice that is "like the sound of many waters." tells John to "write what you have seen, what is, and what is to take place after this." ${ }^{60}$ The book of Revelation accomplishes each of these tasks in turn. It begins with an account of John's vision of the risen Jesus ("what you have seen"). It then continues with a record of Jesus' messages to the seven churches of Asia Minor, assessing their current situation, praising the faithful, and admonishing those who have strayed ("what is"). The bulk of Revelation is devoted to the third task and describes a series of visions of the end times ("what is to take place after this"). ${ }^{61}$

Thompson, The Book of Revelation: Apocalypse and Empire (New York: Oxford University Press, 1990), 164-7, 171-85.

${ }^{56}$ Yarbro Collins, Crisis and Catharsis, 101.

${ }^{57}$ See: Steven J. Friesen, Imperial Cults and the Apocalypse of John: Reading Revelation in the Ruins (Oxford: Oxford University Press, 2001), 46, 53. Friesen's argument here is based on archeological evidence. There was a statue of Titus at the temple of the Sabastoi at Ephesus.

${ }^{58}$ Rev. 1:13.

${ }^{59}$ Rev. 1:14-15.

${ }^{60}$ Rev. 1:19.

${ }^{61}$ I am borrowing this convenient approach to the summary from: Bart D. Ehrman, The New Testament: A Historical Introduction to the Early Christian Writings (New York: Oxford University Press, 2008), 471. 
The literary structure of the work poses interpretive difficulties, chief among which are the repetitive sequences of visions that make a literal interpretation of the narrative extremely difficult. The world is repeatedly beset by several series of plagues-let loose first by the opening of seven seals, then by the sounding of seven trumpets, and subsequently by the pouring out of seven bowls - and at the end of each the world is completely destroyed only then to be found back intact and ready to be beset anew by even more terrible tribulations. Given these repetitive visions of the world's destruction, it would be impossible to chart the narrative on a linear chronological timeline. These interpretive difficulties are alleviated, however, if we assume that the book has a recapitulative structure that repeats the core elements of Revelation's message: “(a) persecution, (b) punishment of persecutors, and (c) salvation of the persecuted.",62 The bulk of the narrative proceeds in cycles, each of which brings the reader's focus back to the edge between the precarious present and the imminent end. The summary of these visions offered below is not meant to be exhaustive, but rather to give the reader a sense of the "imaginative construction" that John of Patmos puts upon the events of his time, the critique of sovereign and imperial power that runs through the text, and the captivating nature of some of its most enduring images.

After Jesus dictates his letters to the seven churches of Asia Minor, John is taken up to heaven, where he sees God seated on a throne. Gleaming as if he were made of gemstones, God is surrounded by four heavenly beings in animal form and twenty-four enthroned elders, who fall at his feet and "cast their crowns before the throne" in a gesture of worship and an

\footnotetext{
${ }^{62}$ Adela Yarbro Collins, "The Book of Revelation," in The Continuum History of Apocalypticism, eds. Bernard McGinn, John J. Collins, and Stephen J. Stein (New York: Continuum, 2003), 199. There are, of course, numerous other ways to interpret the narrative structure of Revelation. See, for instance: Schüssler Fiorenza, The Book of Revelation, 170-7.
} 
acknowledgment of his complete sovereignty. ${ }^{63}$ He holds a scroll with seven seals on which is written the future history of the world. When no one worthy to open the scroll can be found in heaven or on earth, John begins to weep. However, he soon sees Jesus, figured as a "Lamb standing as if it had been slaughtered." ${ }^{, 4}$ The worthy Lamb takes the scroll from God, opening it one seal at a time. As each seal breaks, new terrors are unleashed upon the world. The iconic four horsemen bring war, conquest, famine, and death. With the opening of the sixth seal, a great earthquake turns the sun black and the moon to the color of blood. The stars fall to earth and the sky vanishes "like a scroll rolling itself up." ${ }^{.65}$ The opening of the seventh seal brings a period of complete silence. It then inaugurates a violent narrative recapitulation, as another sequence of terrifying catastrophes begins. This time, John sees seven trumpeting angels, who inflict a series of disasters that recall the plagues let loose on Egypt in Exodus: hail and fire destroy the land and trees, the sea turns to blood, the waters are poisoned, the light from the sun and the moon is darkened, an army of locusts with scorpion tails torture the unfaithful "who will seek death but will not find it, ${ }^{, 66}$ and finally a massive cavalry of fire- and sulfur-spewing horses lay waste to a third of mankind. The sounding of the seventh trumpet signals an end to these terrors and the beginning of the Kingdom of God.

However, it also inaugurates another terrifying vision. Satan, in the form of a dragon, wages a war against Michael and his angels in heaven, but is defeated. He is then thrown to earth and makes war on God's children. Standing at the edge of the sea, he looks on as a sevenheaded beast emerges from the water and assumes the power and the throne of the dragon. The beast will be worshipped by the entire world, "given authority over every tribe and people and

\footnotetext{
${ }^{63}$ Rev. 4:10.

${ }^{64}$ Rev. 5:6.

${ }^{65}$ Rev. 6:14.

${ }^{66}$ Rev. 9:6.
} 
language and nation." ${ }^{67}$ Yet the duration of his rule will be limited to a (symbolic) period of three and a half years, as we are told in Daniel. To John's audience, the identity of this beast would have been clear. It is Rome. Its seven heads on which are inscribed "blasphemous names" are those emperors who were worshipped as gods. ${ }^{68}$ A second beast then rises out of the earth, exercising "all the authority of the first beast on its behalf" and commanding all peoples to worship its predecessor, perhaps a reference to the Roman imperial cults. ${ }^{69}$ The second beast also requires that all people wanting to participate in the economy bear a mark signifying the numerical equivalent of the beast's name $-666 .^{70}$ After this terrifying vision, John once again offers the faithful some reassurance, as he describes Jesus swinging his sharp sickle over the earth, reaping an eschatological harvest, trampling the grapes of wrath, and producing a flow of blood "as high as a horse's bridle, for a distance of about two hundred miles.",71

Seven more angels then appear before John and each pours out a bowl of God's wrath, plunging the earth into new a series of terrors: painful bodily sores, bloody water, scorching heat, darkness, drought, a plague of frogs, and an earthquake so violent that it destroys Babylon and all other cities. John then relates a more detailed vision of the destruction of Babylon. The city is figured now as a "great whore...with whom the kings of the earth have committed fornication, and with the wine of whose fornication the inhabitants of the earth have drunk." 72 The whore

\footnotetext{
${ }^{67}$ Rev. 13:7.

${ }^{68}$ Rev. 13:1.

${ }^{69}$ Rev. 13:12. See: Friesen, Imperial Cults, 146.

${ }^{70}$ As Adela Yarbro Collins explains, "many of the coins in circulation in Asia Minor bore the image of the emperor with divine attributes and his name. This aspect of the vision expresses the offense caused by the virtual necessity of using such coins for strict monotheists and strict interpreters of the commandment against images." The number 666 itself is thought by some to be a reference to Nero, following a system of alpha-numeric equivalencies in the Hebrew and Greek alphabets. This reference, along with Revelation's preoccupation with persecution, led (and continues to lead) some scholars to date the book to the 60s AD. See: Yarbro Collins, "The Book of Revelation," 205.

${ }^{71}$ Rev. 14: 20.

${ }^{72}$ Rev. 17:2.
} 
herself is also "drunk on the blood of the saints and the blood of the witnesses of Jesus."73 The angel translates the vision for John, telling him that the seven heads of the beast are the seven mountains on which the whore is seated. This leaves no doubt as to her identity. She is Rome, the city of seven hills. John then witnesses the divine destruction of Babylon, which is followed by a gruesome heavenly feast in which all are invited "to eat the flesh of kings, the flesh of captains, the flesh of the mighty, the flesh of horses and their riders, the flesh of all, both free and slave, both small and great." ${ }^{, 74}$ Strengthened by this feast, Jesus and his forces then decisively defeat "the beast and the kings of the earth" in a cosmic battle. Satan is imprisoned in a bottomless pit for a thousand years and the martyrs and saints are resurrected to rule with Jesus on earth. At the end of this millennium, Satan is released and gathers his forces for war. But they are quickly consumed by heavenly flames and thrown into a lake of fire to be tortured for eternity.

With the forces of evil vanquished, John once again sees Jesus enthroned. There is a second bodily resurrection, this time of the dead who are not among the ranks of the martyrs and saints. They stand before Jesus and await judgment. All are rewarded or punished for their deeds, according to the list of the redeemed contained in the book of life. The damned are thrown into the lake of fire, while the elect remain to rule with Jesus on earth for eternity. There is now "a new heaven and a new earth; for the first heaven and the first earth had passed away, and the sea was no more., ${ }^{, 75}$ A gleaming New Jerusalem descends from heaven, providing a home in which God may dwell with this people. In this eternal kingdom, he "will wipe every tear from their eyes. Death will be no more; mourning and crying and pain will be no more, for

\footnotetext{
${ }^{73}$ Rev. 17:6.

${ }^{74}$ Rev. 19:18.

${ }^{75}$ Rev. 21:1.
} 
the first things have passed away." "76 God's people will be forever secure, the gates of the city "will never be shut...and there will be no night there."77 John then concludes his revelation with a warning from Jesus that the contents of this book should not be sealed, "for the time is near...Surely I am coming soon." $" 78$ Thus concludes the book of Revelation and the Christian bible.

Daniel and Revelation are both books pregnant with interpretive possibilities. For the purposes of this chapter, however, I will limit my analysis to three broad themes, all of which help account for the power of these works as political theodicies that situate historical and contemporary events within a sacred worldview. These three themes are also central to the contexts and the works of Machiavelli, Hobbes, and Morgenthau. First, both biblical texts present us with a critique of sovereign and imperial power. In both, sovereign power is imagined as a beast. Daniel sees four beasts emerge from the sea, each representing one of the empires that conquered and occupied the eastern Mediterranean between the eighth and second centuries BCE. John collapses these four sea beasts into one-a seven-headed monster crawling out of the sea, ready to be vested with the power and authority of Satan. In Revelation, Rome becomes "the ultimate empire, combining all the destructive characteristics of its predecessors."79 To their ancient authors and audiences, however, these beastly images would have carried additional meaning. Ancient Near Eastern mythology describes a primordial struggle between a rightful God and the beasts of the sea. It is a battle between divine order and primeval chaos. ${ }^{80}$ These mythological images are taken up in a new form in the Hebrew bible. God crushes a great multiheaded sea beast called "Leviathan" at the beginning of creation, overcoming the dark forces of

\footnotetext{
${ }^{76}$ Rev. 21:4.

${ }^{77}$ Rev. 21:25.

${ }^{78}$ Rev. 22:10, 20.

${ }^{79}$ Friesen, Imperial Cults, 202.

${ }^{80}$ Collins, "From Prophecy to Apocalypticism," 74.
} 
chaos and providing the conditions for order on earth. His followers remind God of this feat when they plead with him for deliverance: "You divided the sea by your might; you broke the heads of dragons in the waters. You crushed the heads of Leviathan; you have him as food for the creatures of the wilderness. ${ }^{.81}$ In Isaiah, we are told that God will once again battle the great sea monster as a preliminary to the restoration of Zion: "On that day the Lord with his cruel and great and strong sword will punish Leviathan the fleeing serpent, Leviathan the twisting serpent, and he will kill the dragon that is in the sea." ${ }^{, 82}$ The slaying of this chaos monster is necessary for the establishment and renewal of divine order on earth.

Thus, when Daniel and John of Patmos cast sovereign power as a sea beast, they are presenting a more thoroughgoing critique than we might initially assume. Sovereign power is allied with the forces of primeval chaos. The promise of order offered by Hellenic institutions or the Pax Romana is illusory. Worldly empires are antithetical to divine order. Despite any appearances to the contrary, the world is radically out of joint and it will not be righted until God eliminates the forces of chaos and makes his sovereignty manifest on earth. With the establishment of the Kingdom of God, not only does John see "a new heaven and a new earth" but also that "the sea was no more." ${ }^{" 83}$ The source of primeval chaos and the home of Leviathan are forever banished.

Second, both Daniel and Revelation suggest that God's sovereignty is, at least in part, sovereignty over history. Those suffering the persecutions of Antiochus IV Epiphanes or the traumas of Roman rule may well have seen themselves as the victims of radically contingent and inexplicable events. Yet, for both Daniel and John of Patmos, these events are rendered meaningful by their location in an eschatological drama that culminates in the cataclysmic

\footnotetext{
${ }^{81}$ Ps. 74:13-14. The same beast is also called "Rahab." See: Ps. 89:10; Job 26:12-13; Isa. 51:9.

${ }^{82}$ Isa. 27:1.

${ }^{83}$ Rev. 21:1.
} 
reassertion of divine power. Both books offer a vertical and a horizontal meaning for earthly events. On a vertical level, they cast the events on earth as the product of actions in heaven. Daniel sees the Hellenic wars as earthly shadows of heavenly battles between angelic princes, while John of Patmos reveals that Satan's reign of oppression on earth is the product of the dragon's conflict with angelic forces in heaven. On a horizontal level, both books bring narrative coherence to history. The sequence of empires and the apocalyptic timetables offered in Daniel suddenly render over 500 years of conquest and persecution of Jews meaningful. They allow his audience to locate its present predicament in apocalyptic time, to recognize that Antiochus' reign will be short and that the violent persecution of Jews will soon end. While God may have temporarily ceded his control over worldly history, he has revealed its outlines to his followers so that they may make narrative sense of their place in time. Revelation collapses the longer historical vision of Daniel, a feat achieved metaphorically by combining the latter's four sea beasts into one absolutely terrifying creature. The result, as Adela Yarbro Collins explains, "is a reduction of attention to history and a focus on the terrors of the recent past and the present." ${ }^{84}$ John of Patmos locates his audience in the last great crisis before the end times, allowing them to see Roman oppression as a causal and meaningful prerequisite to the kingdom of God. ${ }^{85}$ In spite of these temporal differences, both Daniel and Revelation achieve the same narrative goal. They offer a vision of the end that brings retrospective coherence to political events that seem threatening, inexplicable, and radically contingent.

Finally, both works demonstrate that one of the ultimate aims of this historical denouement is an overcoming of difference and conflict. In Daniel, the borders and distinctions between groups melt away. The son of man will rule over "all peoples, nations, and languages,"

\footnotetext{
${ }^{84}$ Yarbro Collins, "The Book of Revelation," 203.

${ }^{85}$ Friesen, Imperial Cults, 159.
} 
his total dominion guaranteed by the complete servitude and obedience of all his people. ${ }^{86}$ The differences of race, nationality, and language will be obliterated as God gathers his people back from the corners of the earth to be ruled as one. This theme is even more pronounced in Revelation. With the restoration of divine order on earth, not only is evil abolished, but so too are all of the previous markers of difference. Jesus promises his faithful followers "a new name" and new clothes - the white garments that befit those who are glorious and exalted. ${ }^{87}$ Only once the elect have completely surrendered to his transformative omnipotence will they be fit to be pillars in God's temple and to share the throne of Jesus. ${ }^{88}$ With evil vanquished and worldly differences eliminated, the New Jerusalem will descend from heaven "prepared as a bride adorned for her husband" and there shall be no more death, no more tears, and no more pain. ${ }^{89}$ Without fear of conflict, the gates of the city will remain forever open. God's definitive and final establishment of his sovereignty on earth destroys all of the boundaries, differences, and conflicts that define the political condition. Revelation and Daniel thus offer their audiences not only the promise of a world without persecution but also a seductive vision of a world without politics.

\section{Containing the Apocalypse}

These apocalyptic texts and the broader worldview that they both reflect and cultivate occupy a troubled place within the Judeo-Christian tradition. While they may well have offered hope and consolation to those struggling to make sense of persecution and oppression in a world that seemed radically out of joint, they also generated antinomian enthusiasms that proved

\footnotetext{
${ }^{86}$ Dan. 7:14, 27.

${ }^{87}$ Rev. 2:17, 3:5.

${ }^{88}$ Rev. 3:12, 21.

${ }^{89}$ Rev. 21:2, 4.
} 
difficult to control. As I discuss below, the difficulty of controlling these enthusiasms is a central preoccupation for Paul and especially for Augustine, two of the founding thinkers in the Christian realist tradition. The kinds of responses that these two thinkers develop to apocalypticism will then be used and adapted by later political realists, like Machiavelli, Hobbes, and Morgenthau. Yet the antinomian potential of Daniel and Revelation is not immediately obvious. Neither Daniel nor Revelation explicitly encourages active agency on the part of its audiences. Daniel's politics are overtly quietist. While the text was written and compiled during the period of the Maccabean revolt, its author offers little support for this outright challenge to sovereign and imperial power. Instead, he celebrates "the wise," who "shall give understanding to many" but also "fall by sword and flame, and suffer captivity and plunder." 90 By promising a bodily resurrection, Daniel consoles potential martyrs and frees them from a fear of violent death. ${ }^{91}$ But the author certainly does not urge them to political action. He distinguishes the wise from those who rely on military force and are of "little help," likely a thinly veiled reference to the Maccabees. ${ }^{92}$ Similarly, John of Patmos does not encourage active revolt against Rome. The battle of the end times will be fought by Jesus and his angels against Satan and his demons. Babylon will be destroyed by God "in a single day," rather than by the plodding and precarious efforts of mere men. ${ }^{93}$ Believers will exercise agency through prayer, prophecy, and martyrdom. ${ }^{94}$

\footnotetext{
${ }^{90}$ Dan. 11:33.

${ }^{91}$ Collins, "Daniel," 35.

${ }^{92}$ Levine, "Daniel," 1256, n. 11:33-34. See also: Collins, "From Prophecy to Apocalypticism," 75.

${ }^{93}$ Rev. 18:8.

${ }^{94}$ There are two passages in Revelation that are potentially ambiguous on this point. The account of the final eschatological battle between the beast and the Lamb tells us that "those with [the Lamb] are called and chosen and faithful" (17:14). Earlier, John of Patmos describes the 144,000 followers of the Lamb, who follow him "wherever he goes" (14:4). It is not at all clear in the text that these followers will join Jesus in the eschatological battle. As Adela Yarbro Collins notes, "these two passages... seem to show that the author was aware of [a] tradition [for instance, in the apocalyptic materials among the Dead Sea Scrolls] that the elect would fight in the last battle. But they are just glimpses of such an idea and are not at all emphasized. The dominant conception of the final holy war
} 
However, despite their explicit quietism, the texts contain immense antinomian potential. First, any discouragement of active political agency has to overcome the force of a set of terrifying images that cast sovereign power as the primeval force of chaos. The success of the message of quietism assumes an audience capable of accepting that they are living through a period of profound crisis and that their political sovereign is the chaotic antithesis to divine order. It further assumes that, faced with this interpretation of the facts, this audience will be willing to limit their role in the eschatological drama to patient endurance and martyrdom. While Daniel and Revolution have certainly inspired some quietist movements, history suggests these competing demands are just as easily resolved in favor of antinomian enthusiasm. ${ }^{95}$ Second, as we have seen, both texts deploy a dense network of symbols, which may ultimately prove difficult to control. Especially as part of a public performance or reading, the use of imagery and symbolism allows the audience to experience for themselves the revelation that is being "“re-presented' or re-actualized for them." 96 Like the author of the apocalypse, the audience can attempt to decode the cryptic symbolism and imagery, thereby reliving the experience of the author and appropriating the revelation for themselves. Yet, because it invites interpretation, this dense symbolism guarantees that the apocalyptic text is almost infinitely flexible. ${ }^{97}$ It can be, and indeed it has been, appropriated for both quiet sic and activist ends. Third, the violent imagery in both texts is ambiguous. Those who remain on earth for the final tribulations are subjected to terrors and tortures that are so unbearable that they cause their victims to envy the dead. The wicked are afflicted, consumed, and trampled until the earth is

is similar to that of Daniel, where people will participate in the new order brought about by the eschatological battle but not in the battle itself." See: Adela Yarbro Collins, Cosmology and Eschatology in Jewish and Christian Apocalypticism (Leiden: E.J. Brill, 1996), 207.

${ }^{95}$ John J. Collins, "The Zeal of Phinehas: The Bible and the Legitimation of Violence," Journal of Biblical Literature 122, no. 1 (2003): 17.

${ }^{96}$ Aune, "The Apocalypse of John," 90.

${ }^{97}$ Paula Fredriksen, From Jesus to Christ: The Origins of the New Testament Images of Christ (New Haven: Yale University Press, 2000), 33. 
flooded with their blood. A quietist interpretation suggests that this "violent imagery was apparently intended to release aggressive feelings in a harmless way," providing a catharsis for the faithful and the powerless. ${ }^{98}$ Yet the symbolic flexibility of apocalyptic works offers no interpretive guarantees. These works' ambiguous treatment of violence treads a fine line between the cathartic and the inflammatory. ${ }^{99}$

Among early Christians, the thinkers most attuned to the potential dangers of apocalyptic rhetoric and imagery are Paul and Augustine - the two foundational figures of a Christian strand of political realism. ${ }^{100}$ Both share with later realists a pessimistic view of human nature and a concern with the imperative of political order. Paul saw in human nature a tragic conflict between our intentions and our actions: "For I do not do the good I want, but the evil I do not want is what I do... So then, with my mind I am a slave to the law of God, but with my flesh I am a slave to the law of sin." ${ }^{101}$ For Augustine, humanity has been condemned by original sin to both suffer and commit great evils. Our love of "futile and harmful satisfactions" dooms us to a life of sheer misery. ${ }^{102}$ For both thinkers, this evil is the root cause of human conflict. The

\footnotetext{
${ }^{98}$ Yarbro Collins, Crisis and Catharsis, 171.

${ }^{99}$ Yarbro Collins acknowledges this. See: Crisis and Catharsis, 171.

${ }^{100}$ More than anyone else, Reinhold Niebuhr is responsible for making visible and shaping a Christian realist tradition that looks back to Paul and Augustine as foundational thinkers. Niebuhr is particularly interested in Paul's conception of human nature, which centers on the persistence of sin even in the face of sincerely held moral and religious ideals. Augustine more fully develops this account of human nature and adds to it a concerted attention to "the social factions, tensions, and competitions which we know to be well-nigh universal on every level of community." See: Reinhold Niebuhr, "Augustine's Political Realism," in The Essential Reinhold Niebuhr: Selected Essays and Addresses, ed. Robert McAfee Brown (New Haven: Yale University Press, 1986), 124. On the centrality of Paul to Niebuhr's conception of human nature, see: Richard Crouter, Reinhold Niebuhr: On Politics, Religion, and Christian Faith (Oxford: Oxford University Press, 2010), 41-58. On Niebuhr's Christian realism, see: Robin W. Lovin, Reinhold Niebuhr and Christian Realism (New York: Cambridge University Press, 1995), esp. 132. Niebuhr is undoubtedly engaged in a bit of retrospective tradition-building in order to legitimize his own position. However, the pessimistic account of human nature and the preoccupation with questions of power and the imperative of political order in the work of both Paul and Augustine means that there are some "family resemblances" between their thought and that of later (self-identified) realists, Christian or otherwise.

${ }^{101}$ Rom. 7:19, 25.

${ }^{102}$ Augustine, Concerning The City of God Against the Pagans, trans. Henry Bettenson (Harmondsworth: Penguin, 1972), Bk. XXII, Ch. 22, 1065. All subsequent citations to this volume will be in the following format: XXII.22, 1065.
} 
purpose of political order is to contain this conflict and punish this evil. ${ }^{103}$ Paul calls on everyone to "be subject to the governing authorities," which are "instituted by God." Political resistance will incur divine judgment, "for rulers are not a terror to good conduct, but to bad." 104 Similarly, Augustine points to the existence of sovereign power as evidence that God has not wholly abandoned his people. Just as parents and educators cane stubborn children, secular sovereigns exist to punish sin, "overcome ignorance and to bridle corrupt desire." 105 So much do we desire an escape from evil and chaos that we prefer "subjugation at the hands of victors to total destruction by the devastation of war."

This commitment to the problem of political order sits uneasily with an apocalyptic worldview. While he wrote before the composition of Revelation, Paul nonetheless had to contend with the apocalypticism that captivated many early Christians. According to some of the accounts in the gospels, Jesus had told his followers that the end times were imminent. Some among them would "not taste death until they see that the kingdom of God has come with power."107 Paul himself accepted the imminence of the end times, whilst refusing to engage in precise chronological speculation. ${ }^{108}$ Alongside his despair about human nature sits a radical hope about the Second Coming of Jesus (the parousia). His earliest epistle, the first of his letters to the Thessalonians, attests to this belief. The letter suggests that some of those whom Paul had converted during an earlier visit to Thessalonica had died, leading to questions among the living about the status of their deceased brethren at the parousia. Paul comforts his readers by telling

\footnotetext{
${ }^{103}$ While this position is elaborated in far more detail in Augustine's work, it is also present in Paul's epistle to the Romans: "for [the ruler] is God's servant for your good. But if you do what is wrong, you should be afraid, for the authority does not bear the sword in vain! It is the servant of God to execute wrath on the wrongdoer" (13:4).

${ }^{104}$ Rom. 13:1, 3. Biblical scholars are quick to point out that this famous passage may not be representative of Paul's views on sovereign power. See, for instance: 1 Cor. 2:6-8; 15:24-26. However, for our purposes, Rom. 13 is an accurate summary of what many take to be Paul's contribution to a particular kind of "theology of the state."

${ }^{105}$ Augustine, City of God, XXII.22, 1066.

${ }^{106}$ Augustine, City of God, XVIII.2, 762.

${ }^{107}$ Mark 9:1.

${ }^{108}$ He wisely refuses to set a precise date. See: 1 Thess. 5:1-11.
} 
them that "through Jesus, God will bring with him those who have died."109 He reaffirms the imminence of the end times, suggesting that "we who are alive" will witness them. ${ }^{110}$ Yet, while the parousia is imminent, it will nevertheless "come like a thief in the night."111 At one moment, there will be "peace and security," while in the next "sudden destruction will come upon [the wicked], as labor pains come upon a pregnant woman, and there will be no escape!"112 The faithful of Thessalonica will be armed and ready for this surprise, for they are "children of light and children of the day." In preparation for the parousia, they will "put on the breastplate of faith and love, and for a helmet the hope of salvation."113 Thus prepared, the Thessalonians could look forward to the imminent end as the time at which their faith would be rewarded and their suffering redeemed.

However, these words of apocalyptic consolation and hope seem to have encouraged enthusiasm and disorder in Thessalonica. A second letter suggests that some Thessalonians thought that the end times had begun. ${ }^{114}$ On this assumption, some appear to have quit their jobs and become a burden on others. ${ }^{115}$ Paul condemns this "disorderly" and "undisciplined" behavior, reminding his audience that while he and his fellow missionaries were in the community, they worked for their meals and were a burden on no one. ${ }^{116}$ His theological argument in the letter defers the apocalypse by providing a list of events that must happen before the end times. A "lawless one" is currently restrained but will be revealed. He will exalt himself "above every so called god or object of worship" and take "his seat in the temple of God,

\footnotetext{
${ }^{109} 1$ Thess. 4:14.

${ }^{110} 1$ Thess. 4:15.

1111 Thess. 5:2.

1121 Thess. 5:3.

1131 Thess. 5:8.

${ }^{114}$ Biblical scholars debate whether Paul wrote 2 Thessalonians. For our purposes here, the debate over authorship is not particularly important. The letter forms part of a Pauline tradition of political thought/political theology.

1152 Thess. 3:6-15.

${ }^{116} 2$ Thess. 3:8. The word that is translated as "idle" in the NRSV is ataktos, which means "disorderly" or "undisciplined." I have therefore opted for those words here.
} 
declaring himself to be God." ${ }^{\text {"117 }}$ This figure, whose coming "is apparent in the workings of Satan," is already operating covertly. ${ }^{118}$ Once the agent of restraint (the katechon) is removed, the lawless one will be revealed and Jesus will annihilate "him by the manifestation of his coming," thereby initiating the cosmic battle of the end times. ${ }^{119}$ The "lawless one" is often taken to be some kind of Antichrist figure, an agent of Satan analogous to the false prophet of Revelation. The identity of the katechon is less clear. Paul tells the Thessalonians that they "know what is now restraining" the lawless one. Interpreters have suggested that Paul is referring to a false prophet, an emperor, or the Roman Empire itself. As we shall see in chapter 4, the identity of this figure is matter of debate both historically and among contemporary political theologians. For our purposes here, it is sufficient to stress that when faced with the social disorder and enthusiasm generated by a captivating account of an imminent end, Paul sought to temporally displace the apocalypse and return his audience to "normal time."

In the centuries that followed, Christianity was transformed from a messianic sect of Judaism into a powerful religious and political institution in its own right. In $312 \mathrm{CE}$, Constantine converted to Christianity and, in the following year, issued an edict of religious toleration. Christianity's allegiance with imperial power meant that it urgently "had to come to terms with its foundational prophecy ('The kingdom of God is at hand!'), especially as it was embodied in the Book of the [Revelation]." ${ }^{120}$ Early attempts to neutralize the political threat of apocalypticism tended to adopt one of three strategies: to acknowledge that the end was imminent while explaining its postponement, to divest the relevant texts of any literal meaning

\footnotetext{
1172 Thess. 2:4.

1182 Thess. 2:9.

1192 Thess. 2:8.

${ }^{120}$ Paula Fredriksen, "Apocalypse and Redemption in Early Christianity: From John of Patmos to Augustine of Hippo,” Vigilae Christianae 45, no. 2 (1991): 151.
} 
and embed them in the neutral ground of allegory, or to reject them altogether. ${ }^{121}$ Among these attempts at neutralization, the work of Augustine of Hippo stands as the most theologically sophisticated and historically significant. ${ }^{122}$ Two aspects of Augustine's historical context made this work especially urgent. First, the area of North Africa in which Augustine preached and wrote was full of enthusiastic Christians with apocalyptic expectations. ${ }^{123}$ For many of these apocalypticists, the world was nearing its close. Based on a peculiar but persistent interpretation of Jewish and Christian scripture, these apocalypticists estimated that the end of days would occur when the world was 6,000 years old. Estimating that Christ had been born in the world's $5,500^{\text {th }}$ year, they expected the apocalypse in 500 CE. It was less than a century away. ${ }^{124}$

Had they not been activated by a political crisis, these beliefs might have remained fairly innocuous. After all, the apocalypse was looming but not imminent. However, a second development in the early fifth century gave these hopes and fears an acute sense of urgency. In $410 \mathrm{CE}$, Alaric and the Visigoths sacked Rome. They pillaged the city, sending refugees to calmer regions like North Africa, burdened with terrifying memories of violence and destruction. The apocalyptic significance of this event cannot be overstated. After Constantine's conversion, Christians had come to see the Church and the Empire as "chronologically and geographically

\footnotetext{
${ }^{121}$ Fredriksen, "Apocalypse and Redemption," 152-5. I am using the word "strategy" here to refer to a rhetorical strategy, or an appeal to the rational capacities, normative commitments, or emotional and imaginative sensibilities of one's audience.

${ }^{122}$ Augustine's work drew heavily on that of the Donatist theologian Tyconius, who reinterpreted Revelation and "provided the point of departure for what is most brilliant and idiosyncratic in Augustine's own theology." See: Fredriksen, "Apocalypse and Redemption," 157. Tyconius' commentary on Revelation has been lost. However, scholars have been able to reconstruct some of its central moves by tracing citations of Tyconius in the work of later scholars, including Augustine.

${ }^{123}$ Fredriksen, "Apocalypse and Redemption," 151.

${ }^{124}$ For a thorough analysis of the connection between apocalyptic predictions and Christian chronology, see: Richard Landes, "Lest the Millennium be Fulfilled: Apocalyptic Expectations and the Pattern of Western Chronography 100-800 CE," in The Use and Abuse of Eschatology in the Middle Ages, eds. Werner Verbeke, Daniel Verhelst, and Andries Welkenhuysen (Leuven: Leuven University Press, 1988), 137-211.
} 
coextensive." ${ }^{125}$ The Pax Romana was widely understood as the world's final age. Thus, if one wanted to calculate when the world would end, one simply had to figure out when Rome would fall. Among pagans, Rome was seen as the "eternal city" that enjoyed divine protection. As long as the city endured, "then, the Empire (meaning the world) must survive." ${ }^{.126}$ The fall of Rome therefore carried apocalyptic significance for both Christians and pagans. Among many Christians, particularly in North Africa, it was taken to be the beginning of the terrifying sequence of events described in Revelation. For pagans, who had been the victims of repressive Christian persecution in the closing decades of the fourth century, the destruction was Rome's punishment for abandoning its ancient gods. Some Christians were even tempted to accept this pagan interpretation. If the pagan gods could wreak this kind of destruction, perhaps they should be heeded. ${ }^{127}$ The combination of religious enthusiasm and political crisis thus created a climate of rampant apocalypticism in North Africa and it fell to Augustine, among others, to try to defuse it.

Augustine uses a three-part strategy in his response to this apocalyptic enthusiasm. First, he espouses a tragic view of worldly history. While the world will eventually end at some point in the distant future, the saeculum is marked by inescapable conflicts whose recurrence is guaranteed by human vice. The fall of Rome is simply another terrible misfortune of the sort that plagues any earthly city. And Rome had seen its fair share of misery before. In $388 \mathrm{BCE}$, the Gauls had invaded and "butchered the senators or as many of them as they could find in all the rest of the city, apart from the Capitol—-the citadel which alone was defended by some means

\footnotetext{
${ }^{125}$ J. Kevin Coyle, "Augustine and Apocalyptic: Thoughts on the Fall of Rome, the Book of Revelation, and the End of the World," Florilegium 9 (1987): 4.

${ }^{126}$ Coyle, "Augustine and Apocalyptic," 3.

${ }^{127}$ Coyle, "Augustine and Apocalyptic," 4.
} 
or other." 128 In this respect, the Visigoths had been less severe, sparing "so many of the senators that the real surprise is that they wiped out any of them." ${ }^{\text {129 }}$ Rome had also been torn apart by internal strife in Sulla's civil wars $(88-87,83-82 \mathrm{BCE})$, which had resulted in widespread death and destruction of property. Augustine's list of Roman woes, which is by no means historically exhaustive, places the latest destruction in tragic perspective. The sack of Rome is simply an isolated and contingent event, devoid of any kind of apocalyptic or cosmic significance. It is precisely the kind of recurrent crisis one should expect in a world mired in sin and misery. ${ }^{130}$ Augustine's conclusion, as J. Kevin Coyle neatly summarizes it, is that "far from being the ultimate catastrophe, the fall of Rome in 410 was simply another sad event in human history-a position that panders to neither total defeatism nor reverent fantasy." ${ }^{\prime 131}$ By occupying a tragic middle ground between defeatism and fantasy, Augustine evinces a disposition toward the world that will be cultivated by other political realists like Niccolò Machiavelli and Hans Morgenthau.

Second, Augustine transforms expectations about the end times into an account of the current struggles of the Church. Toward the end of City of God, he considers the portion of Revelation that describes the millennial reign that is initiated by the binding of Satan and the resurrection of the saints and martyrs. He notes:

[Some people] have been particularly excited...by the actual number of a thousand years, taking it as appropriate that there should be a kind of Sabbath for the saints for all that time, a holy rest, that is, after the labours of the six thousand years since man's creation... Scripture says, 'With the Lord, one day is like a thousand years and a thousand years is like one day' [2 Pet. 3:8], and, on this assumption, there follows, after the completion of six thousand years-six of

\footnotetext{
${ }^{128}$ Augustine, City of God, III.29, 130.

${ }^{129}$ Augustine, City of God, III.29, 130.

${ }^{130}$ Augustine asks in a letter to an apocalyptically-minded colleague: "When...has the earth not been devastated by wars at different times and in different places?" See: Augustine, The Works of Saint Augustine [Electronic Edition], vol. 2, no. 3, trans. Roland Teske (Charlottesville: InteLex, 2001), Letter 199, Para 35, 344. All subsequent citations to this volume will be in the following format: 199.35, 344 .

${ }^{131}$ Coyle, "Augustine and Apocalyptic," 10.
} 
these 'days' - a kind of seventh day of Sabbath rest for the final thousand
years...

With some exegetical maneuvering, Augustine concludes that the span of one thousand years is symbolic, standing "for the whole period of this world's history, signifying the entirety of time by a perfect number."133 He also applies an allegorical interpretation to the first resurrection, concluding that it is the rebirth of the individual soul "which comes here and now through baptism." 134 In contrast, the second resurrection is corporeal and will come at the end of days, as outlined in Revelation. The interval between the two resurrections is the millennium, the indefinite worldly period of the current Church. While this Church is a mixed body, housing both sinners and saints, for the righteous it is "even now...the kingdom of Christ and the kingdom of heaven." "135 With a rapid interpretive sleight of hand, Augustine then asserts that the terrifying Beast of Revelation, previously identified with Rome, is better understood as the hostile world in which Christians find themselves, surrounded by "the people of the unbelievers."136 This spiritual and allegorical interpretation transforms expectations of the imminent end into an account of the immanent reality of the present Church. ${ }^{137}$ In so doing, it divests the apocalypse of its urgent appeal to the enthusiastic imagination and tames ones of its most terrifying images.

\footnotetext{
${ }^{132}$ Augustine, City of God, XX.7, 907.

${ }_{133}^{133}$ Augustine, City of God, XX.7, 908.

${ }^{134}$ Augustine, City of God, XX.7, 906.

${ }_{135}^{135}$ Augustine, City of God, XX.9, 915.

${ }^{136}$ Augustine, City of God, XX.9, 917. To be clear, Augustine does not definitely say that the Beast is not Rome. But his suggestion that it represents "the people of the unbelievers" among whom faithful Christians must live severs the image's connection to any particular empire.

${ }^{137}$ This formulation of the strategy is borrowed from McGinn, "Revelation," 528. McGinn adapts it from: Frank Kermode, The Sense of an Ending: Studies in the Theory of Fiction (New York: Oxford University Press, 1967), 256. Paula Fredriksen characterizes the strategy differently, though no less accurately, when she writes that Augustine de-eschatologizes the events and images of the end times, "transposing them back into the present." See: Fredriksen, "Apocalypse and Redemption," 163.
} 
Third, Augustine combines this allegorical interpretation of the millennium with a reassertion of God's ultimate sovereignty over history, effectively deferring the end times by locating them in a distant and unknowable future. In an argument with distinctly Pauline echoes, he reasons that while Revelation may provide us with a general outline of the events of the end times, the specific chronology is known only to God. In his correspondence with an apocalyptically inclined bishop in Dalmatia, he finds himself consistently returning to Jesus' admonition to his eager followers: "It is not for you to know the times or periods that the Father has set by his own authority." 138 The date of the apocalypse is not something that may be subjected to any useful speculation. Augustine therefore calls upon all those obsessed with chronological speculation to "relax your fingers, and give them a rest." ${ }^{\text {"139 }}$ Yet, while we cannot know the date of the End, we do know the sequence of events that will occur at the end of time. With the exception of his reinterpretation of the millennial rule of Christ and his saints, Augustine literally affirms the general outline of the apocalypse given in Revelation, including the persecution of believers, the return of Christ, the resurrection of the dead, and the Day of Judgment. ${ }^{140}$ Turning away from the dense symbolism of Revelation to the comparatively lucid ground of the gospels, he also considers what we can reasonably know about the apocalypse from Jesus himself. As reported in Matthew, Jesus is perfectly clear about the prerequisite for the end of days: "And this good news of the kingdom will be proclaimed throughout the world, as a testimony to all the nations; and then the end will come."

\footnotetext{
${ }^{138}$ Acts 1:7. Augustine and his correspondent disagree about the interpretation of the passage. The Bishop of Hippo seems to have adopted the old strategy of substituting repetition (of the biblical passage) for methodical persuasion. See: Augustine, Works, 197.1, 320; 197.2, 321; 197.4, 321; 199.1/1, 330; 199.3/7, 332; 199.10, 334; 199.13, 334; $199.18,336 ; 199.8 / 22,338 ; 199.24,339 ; 199.33,344 ; 199.35,345$. The passage also has a certain pride of place as the final biblical citation in City of God, XXII.30, 1091.

${ }^{139}$ Augustine, City of God, XVIII.53, 838. Augustine is referring to the ancient practice of dactylonomy ("finger counting") that was widely used before the adoption of Arabic numerals.

${ }^{140}$ Augustine, City of God, XX.30, 963.

${ }^{141}$ Matt. 24:14.
} 
the end will come, we certainly can be sure that it will not come until the gospel has been preached throughout the world.

This provides Augustine with vast chronological leeway, especially as the number of "inaccessible and inhospitable places" on earth means that the gospel will be slow to spread and credible accounts of its progress seem unlikely. ${ }^{142}$ Even if we did have reliable reports that the gospel was in fact spreading to the farthest reaches of the world, all we could conclude is that the end is closer. We could not name a time or a period. ${ }^{143}$ While we may know the general outlines of the apocalyptic sequence, the fundamental obscurity of God's chronology means that we cannot "impose a plot on time." ${ }_{144}$ Thus, Augustine attempts to affirm much of the account given in Revelation and the gospels, whilst divesting it of its subversive potential in the here and now. In so doing, he offers a strategy that will later be deployed in Thomas Hobbes' political theological arguments.

In sum, beginning with Pauline worries about the dangers of apocalyptic enthusiasm, Augustine offers a series of sustained exegetical attacks on predictions of the imminent End. While it certainly did not prevent continued apocalyptic outbursts throughout the Middle Ages, this approach became the orthodox interpretation of Revelation and "virtually defined the content of all future Catholic commentaries." ${ }^{45}$ Politically, it provided an exegetical response to the antinomian potential of apocalyptic expectations and contributed to the ambitious project of

\footnotetext{
${ }^{142}$ Augustine, Works, 197.4, 321.

${ }^{143}$ Augustine, Works, 197.4, 321.

${ }^{144}$ Fredriksen, "Apocalypse and Redemption," 166.

${ }^{145}$ Fredriksen, "Apocalypse and Redemption," 166 . There had been a powerful consensus among twentieth-century Medieval historians that Augustine's exegetical efforts had been so successful that not only was apocalyptic expectation banished from official theology, but also that its popular enthusiasms were effectively controlled until Joachim of Fiore produced a radically new eschatological account in the twelfth century. Richard Landes, among others, have challenged this consensus by pointing to numerous medieval apocalyptic movements, particularly those that coalesced around $1000 \mathrm{CE}$. Landes' work is an important reminder of the need to separate official church doctrine from local beliefs. He notes: "millennium was indeed local, but universally so; official doctrine was indeed "universal," but barely penetrated local culture." See: Richard Landes, "The Fear of an Apocalyptic Year 1000: Augustinian Historiography, Medieval and Modern Author(s)," Speculum 75, no. 1 (2000), 106: n. 33.
} 
reconciling Christianity's foundational prophecy with sovereign and imperial power. Along with the thought of Paul, Augustine's response also offers us a first taste of the strategies that would be used by later political realists like Machiavelli, Hobbes, and Morgenthau in negotiating the apocalyptic enthusiasms of their respective times.

\section{The Apocalyptic Imaginary}

For both Paul and Augustine, the danger of the apocalypse is not just one of theological misunderstanding. Both thinkers are responding to the effects that apocalyptic ideas and visions have in the world. In Paul's time, some Thessalonians were so captivated by the expectation of an imminent end that they had stopped working and had become a burden on others. They were "disorderly" and "undisciplined." In fifth-century North Africa, accounts of the sack of Rome lent a worldly specificity and imminence to existing apocalyptic speculations. For Augustine, the effects of these expectations could be devastating. Invoking Paul's second letter to the Thessalonians, he reasons that apocalyptic enthusiasm breeds disappointment. Inevitably, the time of the expected end would pass without incident and believers "would think that other false promises had been made to them, and they would give up hope about the reward of faith." ${ }^{146}$ In short, the prophetic basis of Christian belief could unravel. Augustine therefore calls upon the faithful to await the end not with captivated enthusiasm but with a comparatively sober "sincerity of faith, firmness of hope, and...ardor of love." ${ }^{147}$ His counter-apocalyptic response is aimed at undermining the most enthralling elements of the Judeo-Christian apocalypse-its sense of urgency and imminence, its beastly imagery, and its seemingly infinite ability to anticipate the crises of the present. Both Paul and Augustine are thus centrally concerned with the capacity of

\footnotetext{
${ }^{146}$ Augustine, Works, 198.15, 335.

${ }^{147}$ Augustine, Works, 198.15, 335.
} 
the apocalypse to capture the imagination and spur the faithful to potentially dangerous enthusiasms and disappointments.

What might it mean to take this intuition seriously and to theorize the apocalypse not simply as a genre of literature or a worldview, but as an imaginary? Given the visual and imagistic dimensions of apocalyptic works, treating the apocalypse solely as a text or narrative is insufficient. Furthermore, a textual or narrative understanding of apocalypse would be unable to account for the ways in which many of the images from Daniel and Revelation resonate for people and groups who are unaware of their textual origins and have only a vague sense of the Judeo-Christian apocalyptic narrative. Theorizing the apocalypse as an imaginary helps to respond to these facts. Within the biblical and religious studies literature, the "apocalyptic imaginary" and the "apocalyptic imagination" are regularly invoked but rarely the target of conceptual specification. ${ }^{148}$ However, we may be able to make some conceptual progress if we set aside the "apocalyptic" for a moment and begin with the "imaginary." In contemporary social and political theory, an "imaginary" is taken to be a "set of meanings, symbols, values, narratives, and representations of the world through which people imagine their existence." ${ }^{149}$ While the "imagination" is commonly understood as a faculty that inheres in the individual, an "imaginary" is shared and contextual. It exists at a "more or less subconscious level" and shapes the way in which people imagine their common world. ${ }^{150}$ Charles Taylor captures all of these dimensions in his description of a "social imaginary." ${ }^{151}$ For Taylor, an imaginary encompasses

\footnotetext{
${ }^{148}$ See, for example: Collins, The Apocalyptic Imagination, 1-42; Richard K. Emmerson and Ronald B. Herzman, The Apocalyptic Imagination in Medieval Literature (Philadelphia: University of Pennsylvania Press, 1992), 1-35. For an important exception, see: Catherine Keller, Apocalypse Now and Then: A Feminist Guide to the End of the World (Boston: Beacon Press, 1996), 1-35.

${ }^{149}$ Chiara Bottici, "Imaginary, The" in Encyclopedia of Political Theory, vol. 1, ed. Mark Bevir (Thousand Oaks: 2010), 685 .

${ }^{150}$ Bottici, "Imaginary," 686.

${ }^{151}$ There are other conceptualizations of the imaginary in psychoanalytic theory (Lacan) and social theory (Castoriadis). I focus on Taylor here for the accessibility of his approach and because, as we shall see below, his
} 
"the ways people imagine their existence, how they fit together with others, how things go on between them and their fellows, the expectations that are normally met, and the deeper normative notions and images that underlie these expectations." 152 These interpersonal and normative expectations are shaped by "wider perspectives on where we stand in space and time: our relation to other nations and peoples... and also where we stand in our history, in the narrative of our becoming." 153 An imaginary is not primarily the textual, theoretical, or self-consciously reasoned ways in which people think about the world. Rather, it involves the "way ordinary people 'imagine' their social surroundings, and this is not often expressed in theoretical terms, but is carried in images, stories, and legends." ${ }^{154}$ While the imaginary may be carried in these forms, it necessarily exceeds any concrete representation. It exists as a "largely unstructured and inarticulate understanding of our whole situation, within which particular features of our world show up for us in the sense they have." 155

Taylor's description of an imaginary offers a useful conceptual starting point for theorizing the place of the apocalypse in the social and political world. In particular, it provides a way of thinking about the relationships between texts and theories, on the one hand, and social imaginaries and their attendant practices, on the other. While Taylor distinguishes the official doctrines of social institutions from imaginaries, he is attuned to the ways in which the doctrines sometimes transform imaginaries when "taken up and associated with social practices." 156 As we have seen in the case of Augustine's immediate context, it is possible to trace a similar transition between the textual and theological basis of apocalypticism in the Christian tradition and the

theorization falls victim to a similar to a similar pitfall — the tendency to reduce the concept of an imaginary to "the logic of a discourse, or worldview." See: Susan Buck-Morss, Dreamworld and Catastrophe: The Passing of Mass Utopia in East and West (Cambridge: MIT Press, 2000), 11-12.

${ }^{152}$ Charles Taylor, Modern Social Imaginaries (Durham: Duke University Press, 2004), 23.

${ }^{153}$ Taylor, Modern Social Imaginaries, 27.

${ }^{154}$ Taylor, Modern Social Imaginaries, 23.

${ }^{155}$ Taylor, Modern Social Imaginaries, 25.

${ }^{156}$ Taylor, Modern Social Imaginaries, 29. 
expansion of these ideas into a social imaginary that encompasses shared ways of imagining a temporal, spatial, and moral order. Furthermore, theorizing the apocalypse as an imaginary offers room to think about the manner in which apocalypticism transcends and thereafter alters the understanding of these textual roots when taken up in the collective imagination. As Taylor explains, the social imaginary and the textual, theoretical, and doctrinal ideas with which it is infused are mutually inflecting. ${ }^{157}$ The same is true of the link between the textual basis of apocalypticism and the lived belief and enactment of apocalypse in the social world. The apocalyptic texts give birth to an apocalyptic imaginary, while the lived practice and enactment of that imaginary changes the way in which the meaning of those texts is understood across space and time. This ongoing negotiation between text and imaginary may help to explain the continued power of works that were intended to address situations very different from our own.

However, in spite of his conceptual references to images, symbols, and iconography, Taylor's examples (drawn primarily from the history of the modern West) are almost exclusively focused on texts and narratives. While his conceptualization of an imaginary is suggestive, its potential is far from fully realized in the course of his analysis. ${ }^{158}$ He also has remarkably little to say about the metaphorical and semiotic dimensions of imaginaries. Yet understanding these aspects more clearly is necessary if we are to see precisely why the apocalyptic imaginary is so resilient and why some of its elements are socially and politically explosive. Susan Buck-Morss suggests that this is a broader problem in the theorization of imaginaries in contemporary Western political thought, which tends to reduce them to "little more than the logic of a

\footnotetext{
${ }^{157}$ Taylor, Modern Social Imaginaries, 30.

${ }^{158}$ For instance, the following observation about the Tiananmen demonstrations in 1989 is little more than suggestive: "This sense of standing internationally and in history can be invoked in the iconography of the demonstration itself, as in Tianenmen in 1989, with its references to the French Revolution and its citation of the American case through the Statue of Liberty." See: Taylor, Modern Social Imaginaries, 27-8.
} 
discourse, or worldview." 159 While Taylor's conceptualization is useful, as far is it goes, it needs to be supplemented with an appreciation for the ways in which imaginaries metaphorically order the world. Often these cannot be reduced to coherent logical statements. We see relatively simple examples of this metaphorical and semiotic capacity in the familiar images of sovereign power within the history of political thought - the divine father, the body politic, the Leviathan, or the machine. These images are prior to more specific forms of articulation or understanding. As Michael Walzer explains, "the image does not so much reinforce existing political ideas (though it may later be used for that purpose) as underlie them...Thus the image provides a starting point for political thinking, and so long as it is effective, no other starting point is possible." ${ }^{160}$ At the heart of what Taylor calls the "largely unstructured and inarticulate understanding of our whole situation" is therefore a store of images and associations that captivate our collective imagination. While they may remain unacknowledged, they nevertheless serve to order the social and political landscape. When deployed overtly in the service of political ends, they may further serve to secure belief and provoke adherence. Any account of a social or political imaginary must therefore attend explicitly to the complex of metaphors and signifiers through which power is organized and belief is elicited.

This more imagistic conceptualization of an imaginary helps us to recognize the ways in which apocalypticism is something more than simply a genre of revelatory literature or a worldview. It allows us to attend to the effects of the extraordinarily rich semiotic qualities of apocalyptic texts. An illuminator of tenth-century commentary on Revelation characterizes the

\footnotetext{
${ }^{159}$ Buck-Morss, Dreamworld and Catastrophe, 11-12.

${ }^{160}$ Michael Walzer, “On the Role of Symbolism in Political Thought," Political Science Quarterly 82, no. 2 (1967): 194.
} 
visions of the apocalypse as "picture-making words." ${ }^{161}$ Given the density of symbolic imagery in Revelation, it is hardly surprising that it is one of the most illustrated books of the Bible and assumes a consistently central place in the history of Western art. ${ }^{162}$ Yet the words of the text have an imaginative power that exceeds any attempt to specify their concrete meaning in a logical statement or a particular visual representation. Edmund Burke captures this power of "picture-making words" when he compares the effect of a drawing to that of an affecting verbal description in the context of a broader discussion of the aesthetic experience of the sublime. He explains:

If I make a drawing of a palace or a temple, or a landscape, I present a very clear idea of those objects; but then...my picture can at most affect only as the palace, temple, or landscape would have affected in reality. On the other hand, the most lively and spirited verbal description I can give raises a very obscure and imperfect idea of such objects; but then it is in my power to raise a stronger emotion by the description than I could do by the best painting. ${ }^{163}$

Similarly, the imagery of apocalypse always seems to lose something of its power when rendered into any determinate visual form. The rolling up of the sky like a scroll, the seven-headed beast emerging from the sea, or the trampling of the grapes of wrath are most powerful as "obscure and imperfect" ideas that can be inflected with the more particular terrors or hopes of one's own context. The overflowing semiotic resources of the imaginary seem to guarantee the apocalypse a remarkable resilience. While particular expectations of the end might be disconfirmed, the apocalypse itself is never discredited because there are always further events in the world that find resonance within these semiotic resources. ${ }^{164}$ The plagues of locusts, which for early

\footnotetext{
${ }^{161}$ Mary Carruthers, The Craft of Thought: Meditation, Rhetoric, and the Making of Images, 400-1200 (Cambridge: Cambridge University Press, 1998), 152.

${ }^{162}$ See: Frances Carey (ed.), The Apocalypse and the Shape of Things to Come (Toronto: University of Toronto Press, 1999).

${ }^{163}$ Edmund Burke, "A Philosophical Inquiry into the Origin of Our Ideas of the Sublime and Beautiful with Several Other Additions," in On Taste, On the Sublime and Beautiful, Reflections on the French Revolution, Letter to a Noble Lord (New York: P.F. Collier and Son, 1909), 53.

${ }^{164}$ Fredriksen, From Jesus to Christ, 83; Kermode, Sense of an Ending, 8-9.
} 
Christians would have recalled God's punishment of Egypt in Exodus, today become the allegory for the effects of global climate change.

With these further specifications to the concept of an imaginary, it becomes easier to recognize the ways in which apocalypticism might become unmoored from its theological beginnings. As the example of locusts and global climate change suggests, elements of the apocalyptic imaginary continue to recur today in locations far from their original theological roots, often in purportedly secular interpretations of the world. The apocalyptic imaginary has been able to travel beyond conditions in which its core features are believed to be literally true, or even recognized as conceptions originally developing from Biblical sources. Because the apocalyptic imaginary, even in its fully religious form, rarely rises into complete awareness by those who draw upon its resources to make sense of the world, it can come to shape the understandings of those who do not even recognize the ways in which its individual elements were originally seen to be linked. For those who lived within explicitly Christian eras, where apocalyptic belief in at least some form was necessary to the coherence of the entire religious world, the semiotic potential of these resources was often extraordinarily powerful. For those who have followed them in time, these resources remain nonetheless; once loosed upon the world, their semiotic richness makes them extraordinarily difficult to contain.

In this dissertation, I will not assume that apocalyptic thinking must necessarily be grounded in a Judeo-Christian theology. Rather, I will show instances in which elements of this imaginary have shaped the thinking of self-consciously secular political actors as well as those motivated by profound Christian enthusiasm. I thus seek to offer a general conception of the apocalyptic imaginary here which draws out its central structural elements, without presuming that these elements must continue to take their original theological form. In either its theological 
or secular form, I conceptualize an apocalypse as an imminent and cataclysmic end to the known world, along with its attendant "evils." It is a rupture in the apparent temporal continuity of history, a revelatory moment around which the past is given meaning and a radically new future is announced. This conceptualization focuses on elements of apocalypse that are present in, but ultimately transcend, the Christian tradition.

The constituent elements of the "apocalyptic" component of the apocalyptic imaginary require further explanation. First, the end of the world is always imminent. ${ }^{165}$ It will come soon, generally within the lifetime of the conveyer or audience of the apocalyptic message. This sense of imminence is clearly present in the early Christian tradition. As we have seen above, some of the accounts in the gospels indicate that Jesus himself expected the world to end within his own generation. The books of Daniel and Revelation possess a similar sense of imminence. Daniel anticipates that Antiochus' reign is drawing to a cosmic close, while Revelation concludes with the warning and hope that "the time is near." Contemporary secular apocalyptic movements also share a sense of imminence. For instance, those who expect that the world will end in environmental devastation tend to insist that such an end will come 'soon', or at least 'sooner than we think. ${ }^{166}$ As we shall see in Chapter 5, the nuclear apocalypticism of the 1950s and 1960s was centered on the expectation of imminent annihilation.

\footnotetext{
${ }^{165}$ Richard Landes, "Roosters Crow, Owls Hoot: On the Dynamics of Apocalyptic Millennialism," in War in Heaven/Heaven on Earth: Theories of the Apocalyptic, eds. Stephen O'Leary and Glen S. McGhee (London: Equinox, 2005), 21-2, 26-7.

${ }^{166}$ For an outline of these kinds of claims, see: David Howard Davis, Ignoring the Apocalypse: Why Planning to Prevent Environmental Catastrophe Goes Astray (Westport: Praeger, 2007), 3-24. One may rightly wonder about the degree to which claims about the imminence of environmental catastrophe are strategic and motivated by need to effect difficult changes in individual habits. However, this is a question that is not limited to environmental apocalyptic movements.
} 
Second, an apocalypse is cataclysmic. ${ }^{167}$ In the Judeo-Christian tradition, the earth is consumed by plagues and fire, effecting a radical transformation that clears the way for a New Jerusalem. In Revelation, the spiraling narratives of destruction are rife with images of catastrophic natural disasters, rotting flesh, excruciating torture, and ravenous beasts, which serve to present "the unrepresentable" - the divine consumption of the world and most of humanity. ${ }^{168}$ This cataclysm is a form of creative destruction, the necessary preparatory work for the building of a new world. On a secular level, political and economic ideologies with apocalyptic dimensions similarly emphasize the creative power of absolute destruction. For instance, the destructive and cleansing power of revolution in certain strains of Marxist thought shares much with the focus of the apocalyptic imaginary on the pregnant potential of cataclysm. ${ }^{169}$ In contrast, most (though certainly not all) environmental or nuclear scenarios of apocalyptic annihilation treat their cataclysms as purely world destroying, rather than also potentially world-renewing.

Third, an apocalypse brings an end to some real or perceived "evil." For Christians, the apocalypse marks the end of sin and suffering and the arrival of an era in which the elect will live with God on earth, where "death will be no more; mourning and crying and pain will be no

\footnotetext{
${ }^{167}$ The historian Richard Landes has offered the most developed conceptualization of apocalyptic beliefs outside the religious and biblical studies literature. While his conceptualization has influenced my own, I depart from him on the question of the cataclysmic nature of the apocalypse. For Landes, an apocalypse can be classified as cataclysmic or transformational. The latter type of apocalypse involves collective, voluntary world transformation. However, I think that here Landes falls victim to a problem that he himself has diagnosed in the work of other scholars of apocalypticism - a tendency to "subsume the apocalyptic component under the millennial." I would class transformative visions as millennial, for reasons I will explain in more detail below. Here, it is worth noting that transformative visions rarely seem to possess the emphasis on imminence that Landes and many other scholars classify as central to the concept of apocalypse. See: Landes, "Roosters Crow," 26.

${ }^{168}$ This notion of presenting "the unrepresentable" is borrowed from: Keller, Apocalypse Now and Then, 6.

${ }^{169}$ Norman Cohn was the first to make a sustained argument about the apocalyptic character of certain strains of Marxist thought. See: Norman Cohn, The Pursuit of the Millennium: Revolutionary Messianism in Medieval and Reformation Europe and its Bearing on Modern Totalitarian Movements (London: Secker and Warburg, 1957), 30714. Comparatively less scholarly attention has been focused on the cataclysmic apocalyptic dimension of certain strains of neoliberal economic and political thought. For a controversial but thought-provoking discussion on this question, see: Naomi Klein, The Shock Doctrine: The Rise of Disaster Capitalism (New York: Picador, 2008), 3-25.
} 
more, for the first things have passed away." Given the symbolic flexibility of the images of evil in both Daniel and Revelation, religious enthusiasts have rarely suffered from a shortage of historical allegories for the dragons, beasts, and whores that populate the apocalyptic landscape. In secular accounts of the apocalypse, the content of the "evil" that is to be purged is similarly variable. It may include human abuse of the natural environment, particular political or economic arrangements, or dangerous weapons and technologies. ${ }^{170}$

Fourth, an apocalypse is a moment of rupture in the apparent temporal continuity of history. The accounts of the apocalypse in Daniel and Revelation describe the irruption of God into human time. This marks a radical break that dissolves the distinction between secular and divine history. After this, God will dwell among humans on earth, and time, as such, will no longer exist. Even when separated from these theological roots, an apocalypse ruptures "our sense of continuity in time, thus forming a temporal break and omnipresent point of reference around which we subsequently reinscribe our historical and political narratives both leading to the event and flowing from it." ${ }^{\prime 11}$ An apocalypse therefore differs from other events that might be collectively or individually devastating, like death. These events are given meaning by sacred and social "rituals that symbolically affirm social continuity." 172 In contrast, an apocalypse

\footnotetext{
${ }^{170}$ In most (though not all) variants of apocalypticism, religious or secular, the end of "evil" requires the sorting out of people such that only an elect remain to enjoy the new world. In the Christian apocalyptic narrative, this sorting out is done by Jesus on the Day of Judgment. In secular apocalyptic narratives, particularly those animating totalitarian political projects, ideological elites take responsibility for sorting out the saved and the damned. The analysis of the apocalyptic underpinnings of Nazism in Chapter 5 provides an example of this phenomenon. Secular apocalypses that lack some notion of redemption-for example, some visions of nuclear or environmental apocalypse - also tend to lack a commitment to the idea of a chosen elect who will remain after the apocalypse. While some visions of nuclear or environmental apocalypse envision survivors, this remnant is rarely seen to be providentially chosen because of its moral character. Survivors are left by chance, having escaped a sudden death only to endure a more lengthy and painful one. The 1959 film On the Beach is illustrative in this regard.

${ }^{171}$ Antoine Bousquet, "Time Zero: Hiroshima, September 11 and Apocalyptic Revelations in Historical Consciousness," Millennium: Journal of International Studies 34, no. 3 (2006): 741.

${ }^{172}$ John R. Hall, with Philip D. Schuyler and Sylvaine Trinh, Apocalypse Observed: Religious Movements and Violence in North America, Europe, and Japan (New York: Routledge, 2000), 4.
} 
simply cannot be imagined into ritualized or calendric understandings of time. It always exists as both a rupture in and an end to time.

Finally, an apocalypse is revelatory. In an instant, it discloses both the meaning of the past and "the shape of things to come." ${ }^{173}$ In Daniel and Revelation, the apocalypse is revelatory in another sense - it is a transcendent reality conveyed to Daniel and John of Patmos through a vision mediated by an angelic figure. Once this vision has been communicated and interpreted, the upheavals, conflicts, and persecutions of the past and present cease to be the unaccountable contingencies of history and become instead the birth pangs of a new world. Similarly, secular apocalypses reveal a present filled with signs of the imminent end-rising temperatures, species extinction, economic crisis, or conflicts between nuclear powers. An apocalyptic interpretation reveals these events to be signs of an inevitable and imminent world transformation.

Conceptualizing apocalypse as an imaginary allows us to recognize the possibility of many potential "apocalypses." The apocalyptic imaginary includes the overtly theological apocalypses in which God irrupts into history, initiating a bodily resurrection in which the saved are granted immortality and the damned are condemned for eternity. However, it also includes secular apocalypses in which humans alone bring about the end of the world. Furthermore, as I have outlined it here, the apocalyptic imaginary is not committed to a particular vision of the post-apocalyptic world. Christian accounts of the apocalypse envision a millennial kingdom and, eventually, a world in which the elect dwell with God. However, there is disagreement within the Christian tradition about whether the post-apocalyptic world would be hierarchical or radically egalitarian. ${ }^{174}$ There are similar debates among secular apocalypticists, whose postapocalyptic scenarios range from the totalitarian to the anarchic. However, with secularization

\footnotetext{
${ }^{173}$ This phrase is taken from the title of H.G. Wells' 1933 science fiction novel. See also: Carey (ed.), The Shape of Things to Come.

${ }^{174}$ Landes, "Roosters Crow," 25-6.
} 
comes another option - that the entire physical world, or at least all human life, will be completely destroyed. The apocalyptic imaginary, as I have outlined it here, includes such scenarios.

At this point, the apocalyptic imaginary may well seem overly capacious. Yet it is important to stress that it does not encompass all possible forms of eschatological expectation. The centrality of imminence, cataclysm, and rupture to the apocalyptic imaginary means that it necessarily excludes the beliefs of progressive millennialists. Progressive millennialism encompasses a variety of narratives about the future, all of which are linked by the expectation of a coming better age on earth that will be achieved through gradual human transformation, rather than an imminent and destructive cataclysm. ${ }^{175}$ The various agrarian utopian communities that developed in Europe and the United States in the nineteenth century were the products of such beliefs. Similarly, the narratives of progress that lie at the heart of liberal political thought often have a progressive millennialist bent, particularly when they take the form of arguments about "the end of history." catastrophe or violence and it is rarely cast as imminent. This means that while there are elements of progressive millennialism that partake of the apocalyptic imaginary, particularly its

\footnotetext{
${ }^{175}$ Richard Landes has a category of millennial belief that he calls "transformational apocalypticism." He explains that groups with these beliefs hold that the end of the world is imminent (which is Landes' key reason for calling them "apocalyptic") but also that the new world will come about through human transformation, rather than cataclysm. While various kinds of natural catastrophes may play an important role for the groups Landes might classify as transformational apocalypticists, in my view, these events serve as signs of the coming apocalypse, rather than as constituent features of the apocalyptic moment itself. Such signs are often used to convince people to transform themselves in preparation for the end of the world. Because they lack the belief in the constitutive role of cataclysm, I would classify such groups as progressive millennialists. Landes' most extensive case study of such a group is the "Peace of God" movement in southern France in the 990s. See: Richard Landes, "What Happens when Jesus Doesn't Come: Jewish and Christian Relations in Apocalyptic Time," in Millennial Violence: Past, Present and Future, ed. Jeffrey Kaplan (London: Frank Cass, 2002), 245-59.

${ }^{176}$ Francis Fukuyama, The End of History and the Last Man (New York: Free Press, 1992). Fukuyama's account of the "end of history" is certainly eschatological, but it is not apocalyptic. Also, while not itself easily classified as "liberal," Fukuyama shares with liberal political thought a progressive account of history and a commitment to liberal democracy as the best political regime.
} 
revelatory qualities and the emphasis on the purging of 'evil,' expectations of gradual transformation involve separate categories of belief and very different visions of the future.

Yet this distinction should not blind us to the dynamism of beliefs, narratives, and images of the end of the world. There are several historical cases in which progressive millennialism has transformed into full-throated apocalypticism. The case of the Anabaptists at Münster between 1533 and 1535 is a canonical example. This group's beliefs, along with the narratives and imagery that gave them form, shifted from transformational and pacifist to violent and cataclysmic when the expected new world failed to arrive. ${ }^{177}$ There was a similar shift for large groups of Western Franks when hopes for the arrival of Jesus were dashed at the turn of the first millennium. ${ }^{178}$ While these groups did not originally draw on the full resources of the apocalyptic imaginary to make sense of their world, they turned to this imaginary when their prophecies failed. As we shall see in Chapter 5, this is precisely the kind of transformation that Hans Morgenthau worried about. The beliefs and narratives of interwar idealists like Woodrow Wilson may begin as a kind of secular progressive millennialism centered on the hope for a world without war. However, these expectations become apocalyptic when they begin to focus on the need for a final and decisive battle for a singular 'humanity.' Because the apocalyptic imaginary shares narrative and symbolic resources with progressive millennialism, this shift often faces limited resistance.

Even when progressive millennialist beliefs become apocalyptic, they need not erupt in violence. In fact, overt public eruptions of apocalyptic hostility are relatively rare. This does not mean, however, that the imaginary is not at work. In any historical period, there are groups that accept the current political, economic, or moral order "'under protest' even if that protest is,

\footnotetext{
${ }^{177}$ Landes, "Roosters Crow," 30.

${ }^{178}$ Landes, "What Happens when Jesus Doesn't Come," 245-59.
} 
provisionally, silent. They await eagerly the moment when the rules will change, and change dramatically." ${ }^{179}$ The apocalyptic imaginary provides these groups with a way to understand their current circumstances and envision a new world. They can legitimize their expectation of an imminent cosmic transformation by appealing the "signs of the times." For those captivated by the apocalyptic imaginary, the world is "overflowing with meaning and purpose." ceases to be a space of unaccountable contingency and becomes a determined process subject to eschatological interpretation. The apocalyptic imagination rescues suffering, oppression, and cultural discontents from the threat of meaninglessness and makes time reliable. ${ }^{181}$ It allows believers to take everything - political events, cultural shifts, economic downturns, changes in the weather, particular dates - to be signs of an imminent transformation. In short, they become semiotically aroused. As Landes summarizes:

From the people they meet, to the texts they read, to events that happen around them, everything coheres as part of a huge apocalyptic plan, crystalline in its clarity and glorious in its implications. Sometimes the plan is nefarious-an international conspiracy by the forces of evil to enslave mankind; sometimes benevolent - the dawn of a new age. In any case, whereas it once existed only in the shadows, scarcely discernable, the signs of its advent are now legible, visible, clear to anyone with discernment. ${ }^{182}$

As we have seen in the case of Judeo-Christian apocalypticism, the symbolic flexibility of texts like Daniel and Revelation guarantees believers a continued source of cosmic analogs that can be made to correspond to almost any contemporary figure or event. For secular apocalyptic believers, this semiotic arousal may work at the level of an unconscious habit or subliminal practice. While they may "not perceive any possible connection between an old text and the current reality...they may be inclined to expect the burning of rainforests, for instance. And they

\footnotetext{
${ }^{179}$ Landes, "Roosters," 31.

${ }^{180}$ Landes, "Roosters Crow," 33.

${ }^{181}$ Cathy Gutierrez, "The Millennium and Narrative Closure," in War in Heaven/Heaven on Earth: Theories of the Apocalyptic, eds. Stephen D. O'Leary and Glen S. McGee (London: Equinox, 2005), 47.

${ }^{182}$ Landes, "Roosters Crow," 33.
} 
may feel some mix of foreboding and inevitability about 'the environment."'183 Whether they are sacred or secular, all apocalyptic believers exist in a world charged with meaning and about to undergo a cosmic transformation. The shape of this transformation remains fundamentally unimaginable at the same time as it haunts the collective imagination.

\section{Conclusion}

In sum, the Judeo-Christian apocalypse emerged in response to specific political circumstances in the Eastern Mediterranean and Asia Minor. The books of Daniel and Revelation offered their audiences thoroughgoing critiques of sovereign and imperial power, a historical narrative through which persecution and trauma could be made meaningful, and the seductive promise of a new world purged of suffering. Yet the dense and flexible symbolic resources in these works have allowed them to capture the imaginations of audiences in circumstances that are radically different from those of antiquity. Within the early Christian tradition, the two thinkers most concerned with the antinomian potential of apocalypticism are Paul and Augustine - two thinkers who would later come to be seen as the foundational voices of a Christian strand of political realism. Both Paul and Augustine take seriously the effects that apocalypticism has in the world, its capacity to captivate the imagination and impel people to potentially subversive forms of enthusiasm. Together, they deploy three strategies of which later political realists will also avail themselves: acknowledging the reality of the apocalypse while deferring its arrival, divesting the apocalypse of its most captivating and terrifying images, and embracing a tragic view of history that eschews the apocalypse's perfectionist impulses. Following an intuition in Paul and Augustine's work, I have argued that the apocalypse is best conceptualized as an imaginary. It is part of the stock of narratives, myths, and images through

\footnotetext{
${ }^{183}$ Keller, Apocalypse Now and Then, 8.
} 
which people make sense of their world together. As I have suggested here, and as will become clear in the following chapters of the dissertation, the apocalyptic imaginary persists not only for those who believe in the literal truth of Jewish and Christian scriptures, but also for purportedly secular political thinkers. The chapters that follow trace the extended and often troubled engagements of three political realists with the apocalyptic imaginary. As we shall see, these engagements are not primarily undertaken at the level of texts, doctrines, or policies, but rather through the images, symbols, and narratives with which we make sense of our political landscape. 


\section{CHAPTER THREE}

\section{NICCOLÒ MACHIAVELLI'S SAVONAROLAN MOMENT}

In his controversial book on Machiavelli, Leo Strauss urges us to take an imaginative leap to find a "surprising Machiavelli who is new and strange, rather than...old and our own."1 Whatever one may think about Strauss or the degree to which he succeeds in his own interpretive task, his insistent invitation to find a Machiavelli who is "new and strange" is a valuable one. Perhaps paradoxically, I attempt to draw out an unexpected Machiavelli by locating him within his contemporary context. But the contextual picture I want to sketch is one that has been largely neglected by scholars of the history of political thought. In Machiavelli's time, Florence was gripped by enthusiastic and rampant apocalypticism, or fears of the imminent end of the known world and a hope for the beginning of an unprecedented future. While the Dominican friar Girolamo Savonarola was at the center of this enthusiastic movement, the apocalypticism that captured the Florentine imagination was broader and deeper than the preaching of a single man. The "Savonarolan moment," as I refer to it here, was a time at which a divine scourge and the remaking of Florence seemed possible and even inevitable. Political upheaval and prophecy combined to transform a hope for a better world into a widespread expectation that God would violently irrupt into secular history and create a heavenly kingdom on earth. For Florentine enthusiasts, the apocalyptic imaginary functioned as a political theology, assigning meaning to struggles of the present by locating them within a sacred narrative that offered the enticing promise of ultimate vindication.

I argue here that Machiavelli's work bears the mark of this context. The final chapter of The Prince, I suggest, is an apocalyptic exhortation that in its rhetoric and imagery amounts to a

\footnotetext{
${ }^{1}$ Leo Strauss, Thoughts on Machiavelli (Chicago: University of Chicago Press, 1978), 12.
} 
secular political reiteration of the Savonarolan message. Machiavelli gravitates toward this apocalyptic solution in The Prince because he has failed to adequately grapple with the contingency of the political world and with the particular crises that plagued contemporary Florence. Yet Machiavelli later turns away from an apocalyptic mode, embracing instead a robustly tragic sensibility characterized by an openness toward and even a celebration of the variability and struggle that characterize politics. However, while Machiavelli turns away from a desire to transform apocalyptic hopes into a worldly project, he never fully abandons these hopes, which continue to haunt his later works.

This chapter proceeds in three parts. First, I sketch the context of the Savonarolan moment in Renaissance Florence, focusing initially on the preaching of the Dominican friar and then broadening the analysis to the ways in which the apocalyptic imaginary transcended Savonarola himself. Second, I offer a close textual reading of the final chapter of The Prince, drawing out resonances between Machiavelli's exhortation and the Savonarolan moment. I also consider why it is that a work that begins with apparently empirical and anti-utopian goals culminates in an apocalyptic exhortation. Third, I trace the way in which Machiavelli turns away from the apocalyptic imaginary in his later work, and particularly in The Discourses, by embracing a tragic sensibility.

\section{The Savonarolan Moment in Florence}

Girolamo Savonarola's (1452-1498) early life made him an unlikely candidate for the role of apocalyptic prophet of a Florentine millennium. He was born in Ferrara, the son of a businessman and the grandson of a learned physician and medical writer. With the help of his grandfather, Savonarola received a humanist education and earned a Master of Arts degree at the 
University of Ferrara. Yet, in the spring of 1475, the young Savonarola surprised his family by running away to join the Observant Dominican friary in Bologna. He offered his reasons for this decision in a letter to his father, explaining that he could no longer stand "the great wickedness of the blind people of Italy, especially when [he] saw that virtue had been completely cast down and vice raised up." ${ }^{2}$ In a world rife with sin, Savonarola was called to become a "knight militant" for Christ. ${ }^{3}$ He first came to Florence in 1482-1487 as a lecturer in theology. At this time, his preaching brought him few followers, "only some simpletons and a few little women," as he later recalled. ${ }^{4}$ In 1490 , Savonarola returned to Florence, assigned by his superiors to the convent of San Marco at the request of Lorenzo de' Medici and under the recommendation of the young philosopher Pico della Mirandola. Savonarola's sense of his mission had now changed. He saw himself as a prophet ${ }^{5}$ who had been called to preach the imminent apocalypse, to urge penitence, and to seek the renewal of the Church. His election to the position of prior of San Marco in 1491 allowed him to reform his community of friars, while his fiery apocalyptic preaching helped him attract a substantial following among Florentines. The swelling crowds at his sermons meant that Savonarola "was soon obliged to move his pulpit from the convent church of San Marco to the Medicean basilica of San Lorenzo and eventually to the immense

\footnotetext{
${ }^{2}$ Girolamo Savonarola, Letter to his Father, Niccolò Savonarola, in Ferrara, 25 April 1475, in A Guide to Righteous Living and Other Works, trans. Konrad Eisenbichler (Toronto: Centre for Reformation and Renaissance Studies, 2003), 36.

${ }^{3}$ Savonarola, Letter to his Father, 36.

${ }^{4}$ Girolamo Savonarola, Ruth Micah, Sermon IV, 18 May 1496, as quoted in: Alison Brown, "Introduction," in Selected Writings of Girolamo Savonarola: Religion and Politics, 1490-1498, eds. and trans. Anne Borelli and Maria Pastore Passaro (New Haven: Yale University Press, 2006), xv.

${ }^{5}$ The earliest evidence of this self-perception is in a letter Savonarola wrote to his mother in 1490. In explaining why he must continuously travel, he references Luke 4:24 and writes "no-one is a prophet in one's own country, so much so that even He was not accepted in His own country." See: Girolamo Savonarola, Letter to his Mother, Elena Savonarola, from Pavia, 25 January 1490, in Guide to Righteous Living, 39. It is not altogether clear how or why Savonarola came to see himself as an apocalyptic prophet. A contextual political explanation might stress the sense of political malaise he encountered upon his return to Florence in 1490. His concern with the decadence and corruption of the Church may have served to reinforce a conviction that the world was somehow out of joint. Savonarola was also not the only apocalyptic prophet in Florence or in Italy at this time. He may have been influenced by the message or the fame of other apocalyptic preachers.
} 
cathedral church of Santa Maria del Fiore.” ${ }^{\circ}$ Florence was receiving Savonarola's apocalyptic message with rapt attention. ${ }^{7}$

Florentine receptiveness to the Savonarolan message was not merely the product of the friar's rhetorical or prophetic skill. The political situation in which the city found itself at the end of the fifteenth century had left Florentines particularly receptive to apocalypticism. In April 1492, Lorenzo de' Medici died, leaving behind a gathering political storm fueled by a brittle regime and an increasingly vocal and dissatisfied elite. Lorenzo's son Piero took over his father's leadership role. Yet despite an apparently smooth transition, many of the city's powerful citizens worried that Piero's power would eventually become tyrannical. Piero's inner circle was very tight, excluding members of the city's elite on whose support rested the future viability of the regime. This domestic unrest was compounded by a foreign threat. In 1493, rumors of a French invasion were spreading through Italy. Charles VIII was coming to make good his inherited claim on the Neapolitan kingdom, with a force whose size and strength was unimaginable to Italians. ${ }^{8}$ In 1494, the French were en route and sought Florentine assistance in easing their way through Tuscany. But Piero chose to maintain the Florentine alliance with Naples. As the French approached, the young Medici leader attempted to maintain a difficult balance between keeping the Neapolitan alliance, on the one hand, and trying to avoid overtly antagonizing the French, on the other. As internal dissatisfaction with the Medici regime grew and Charles' forces marched from Milan to Tuscany, Piero realized that it was time to negotiate with the French. On October $26^{\text {th }}$, he met with Charles and made substantial concessions on behalf of Florence, surrendering the city's fortresses in Pisa, Livorno, Pietrasanta, and Sarzana.

\footnotetext{
${ }^{6}$ Konrad Eisenbichler, "Introduction," Guide to Righteous Living, 7.

${ }^{7}$ This biographical information was compiled from Brown, "Introduction" and Eisenbichler, "Introduction."

${ }^{8}$ Donald Weinstein cites a figure, taken from a late nineteenth century French source, of forty thousand effectives armed with one hundred siege guns. See: Donald Weinstein, Savonarola and Florence: Prophecy and Patriotism in the Renaissance (Princeton: Princeton University Press, 1970), 114.
} 
Florence was at a breaking point. Its citizens were outraged at Piero's surrender of the fortresses and worried about the impending arrival of an army that had already laid waste to a nearby town. The city's executive body, the Signoria, called an emergency meeting of the regime's senior officials. Most of the inner circle was now prepared to abandon Piero. But the French threat still loomed and they decided to dispatch a delegation headed by Savonarola to persuade Charles to either avoid coming through Florence or to restrict the size and movements of his force if he insisted on entering the city. ${ }^{9}$ No firm arrangement was reached. However, during Savonarola's absence, Piero was successfully ousted from power. Sixty years of Medici dominance had ended and a politically disorganized Florence awaited a frightening French army.

This is the political context in which Savonarola's apocalyptic message took shape. Savonarola began his Florentine preaching on Revelation in August $1490 .^{10}$ At this time, his prophecy offered a vivid picture of an apocalypse without worldly redemption. God's wrath would be let loose on everyone. While the friar envisioned the reform of the Church and a universal conversion to Christianity, these changes merely heralded the Last Judgment. They did not suggest the imminent creation of a better world on earth. ${ }^{11}$ This deep pessimism put Savonarola at odds with other apocalyptic prophets in Florence, who also predicted tribulations but saw them as a precursor to world renewal. ${ }^{12}$ Reflecting back, Savonarola recalled the mood of these early apocalyptic sermons with a single evocative line: "I am the hailstorm that shall

\footnotetext{
${ }^{9}$ The reasons why Savonarola was chosen for this mission are not entirely clear. By this time, he was a prominent figure in Florence and he had gained substantial public credibility by seeming to have predicted the city's political calamities in his apocalyptic sermons.

${ }^{10}$ While this was the first time that Savonarola preached on apocalypse in Florence, he may have previously done so elsewhere. After he left Florence for the first time in 1487, Savonarola preached in several cities in the north of Italy. In Brescia, he likely used the Book of Revelation as the textual basis for a prediction that God would soon punish all of Italy. See: Weinstein, Savonarola and Florence, 75.

${ }^{11}$ Donald Weinstein, "Millenarianism in a Civic Setting: The Savonarola Movement in Florence," in Millennial Dreams in Action: Essays in Comparative Study, Comparative Studies in Society and History, Supplement 2 (The Hague: Mouton and Co., 1962), 188; Donald Weinstein, "The Myth of Florence," in Florentine Studies: Politics and Society in Renaissance Florence, ed. Nicolai Rubinstein (Evanston: Northwestern University Press, 1968), 40.

${ }^{12}$ Weinstein, "Myth of Florence," 40.
} 
break the heads of those who do not take shelter."13 The friar's focus in these sermons was on the corruption of the Church, which he took to be a sign of an imminent apocalypse. ${ }^{14}$ Like many of his contemporaries, he pointed to the Turks as alternately the Antichrist or a divine apocalyptic scourge. ${ }^{15}$ Yet as his sermons evolved, the friar's targets became much more local. During Lent in 1491, Savonarola offered what he later called his "terrifying sermon," in which he singled Florence out for the worst of God's apocalyptic wrath. The city would no longer be known as Florentia, but "turpitude and blood and a den of robbers." 16 This would be an apocalypse without worldly redemption and Florence would be God's primary target.

As rumors of a French invasion spread, Savonarola no longer had to look to the Turks as the agents of God's scourge. Charles VIII, Savonarola explained as the French approached Tuscany, was the apocalyptic scourge the friar had predicted. The French invasion was but the beginning of a terrifying sequence of apocalyptic events that the friar had been rehearsing for the last several years. With a tone of reproach, he told his listeners: "long before anyone had heard the noise or smelled any of today's wars, moved by people from beyond the Alps, great tribulations were announced to you. You also know that not two years have passed since I told you: 'Behold the sword of the Lord falling on the earth quickly and swiftly.' Not I, but God predicted it to you. And, look, it has come to pass and it is here." ${ }^{, 17}$ Florence had not listened to the warnings offered by God's messenger. Again, Savonarola reproached his audience: "God has spoken and you did not want to listen to Him. If the Turks had heard what you have heard,

\footnotetext{
${ }^{13}$ As quoted in Roberto Ridolfi, The Life of Girolamo Savonarola, trans. Cecil Grayson (New York: Knopf, 1959), 32.

${ }^{14}$ There are other recurring themes of social injustice and the moral corruption of the wealthy. See: Weinstein, Savonarola and Florence, 98-9.

${ }^{15}$ Weinstein, Savonarola and Florence, 94.

${ }^{16}$ As quoted in Weinstein, Savonarola and Florence, 98.

${ }^{17}$ Girolamo Savonarola, Haggai, Sermon I (November 1, 1494), in Guide to Righteous Living, 89. Emphasis in original. The translator has translated the italicized portion from the Latin that appears in the original: Ecce gladius Domini super terram cito et velociter.
} 
they would have done penance for their sins." ${ }^{18}$ Repentance and moral reform, the friar warned, would not stop the apocalyptic onslaught, but they would offer some protection, even if only in the form of martyrdom. If Florentines did not change their ways, he warned, they should not be surprised "afterwards, when the slaughter will come and everything will be in danger." 19 Thus prepared, the looming invasion of the French took on immense prophetic significance. Faced with an imminent Apocalypse, Florentines drew closer to Savonarola during these tense November days.

Charles entered Florence on November 17, met by a city that had awaited him with "a mixture of fear and wonder." ${ }^{20}$ His stay in Florence was tense and the city's inhabitants had prophetic but also practical reasons to fear the king's wrath. Florence had opposed his Italian campaign and had very recently ousted his new Medici ally. ${ }^{21}$ Charles himself exacerbated an already tense situation by demanding that the government allow Piero's return and by playing the role of the conqueror and insisting on installing himself in the Medici palace. Politically, the situation was defused with the drafting of an alliance between Florence and France and a promise on behalf of the city's officials that they would consider allowing Piero to return. ${ }^{22}$ Yet, when Charles still seemed reluctant to leave, Savonarola was sent to persuade him to move on. According to a contemporary chronicler, the friar entered the meeting wielding a crucifix. He explained to Charles that the king was the chosen minister of God and, as such, should be kind to Florence and continue his mission to Naples as quickly as possible. ${ }^{23}$ In conceiving of Charles' mission in this way, Savonarola was drawing on a well-established prophetic tradition, centered

\footnotetext{
${ }^{18}$ Savonarola, Haggai, Sermon I, 88.

${ }^{19}$ Savonarola, Haggai, Sermon I, 94.

${ }^{20}$ Bartolommeo Cerretani, a contemporary chronicler, as quoted in: Weinstein, "Millenarianism in a Civic Setting," 191.

${ }^{21}$ Weinstein, "Millenarianism in a Civic Setting," 191.

${ }^{22}$ Najemy, History of Florence, 379-80.

${ }^{23}$ Weinstein, Savonarola and Florence, 115. Weinstein is citing Bartolommeo Cerretani here.
} 
on the hope for a second Charlemagne who would prepare the way for the apocalypse by taking Italy, renewing the Church, and finally moving East to conquer and convert the infidel, thereby reducing "the world to a single sheepfold under one shepherd." 24 For his part, Charles was prepared to be persuaded by such an argument. A major spur for his Italian campaign had been apocalyptic fantasies of his role as a Second Charlemagne, recalled to him by exiles from Naples in the French court, as well as envoys from Milan. ${ }^{25}$ Charles and his army promptly left and their departure was widely seen as a miracle. ${ }^{26}$ Savonarola was celebrated by many as the savior of the city.

Florence had been spared the divine scourge that Savonarola had promised, yet his apocalyptic preaching continued. Now, the dominant theme was earthly renewal, rather than worldly annihilation. ${ }^{27}$ No longer singled out for the worst of the tribulations, Florence would now be the site of an apocalyptic rebirth. Because Florence was "the navel of Italy," 28 this spiritual renewal would soon flow outward. In Christian terms, Florentines were God's elect, a chosen people who would be shielded from the worst of the divine violence. However, this status was not unconditional. Once again, Savonarola urged Florentines to purify themselves of their sins and to "attend to the common good of the city."29 If Florence heeded Savonarola's apocalyptic plea, its rewards would be temporal, as well as spiritual. He predicted "Florence will

\footnotetext{
${ }^{24}$ Weinstein, Savonarola and Florence, 113. The origins of the myth of a second Charlemagne lie in the preaching of the French Franciscan Jean de Roquetaillade. Writing in the aftermath of the terrible French defeat at Poitiers in 1356, Roquetaillade predicted an outpouring of divine wrath, as a combination of plagues and popular revolutions swept over the earth, stripping the Church of its wealth and paving the way for the rule of Antichrist in Rome and Jerusalem. These terrors would end by 1367, with the rise of a reforming Pope and the election of the King of France as Holy Roman Emperor. The king would be a second Charlemagne, conquering the world and presiding over a period of unprecedented peace. See: Richard Landes, "Millennialism," in Merriam-Webster's Encyclopedia of World Religions, ed. Wendy Doniger (Springfield, MA: Merriam-Webster, 1999), 733.

${ }^{25}$ Weinstein, Savonarola and Florence, 112.

${ }^{26}$ Weinstein, Savonarola and Florence, 137.

${ }^{27}$ Savonarola scholarship owes much to Donald Weinstein for recognizing this important shift in the friar's preaching. Savonarola himself obscures this shift in his Compendium Revelationum, in which he offers a retrospective account of his apocalyptic preaching.

${ }^{28}$ Girolamo Savonarola, Psalms, Sermon III (January 13, 1495), in Selected Writings, 62.

${ }^{29}$ Girolamo Savonarola, Aggeus, Sermon XIII (December 12, 1494), in Selected Writings, 153.
} 
become richer and more powerful than she has ever been, and her empire will expand into many places. ${ }^{״ 30}$ Yet Savonarola did not abandon the apocalyptic themes of scourge and tribulation. Divine violence was a necessary prerequisite for the friar's promised renewal. Savonarola warned: "God wants to renew His Church—do not doubt this at all—and He will renew it, and He will do so with the sword of tribulations - and soon!"31 At best, Florence's elect status would protect the penitent from the worst of the tribulations. The unrepentant and the unconverted would be the primary targets of God's sword. ${ }^{32}$ Only after this apocalyptic purge would Florence fully realize its chosen status as a New Jerusalem. ${ }^{33}$

The renewal of Florence would be political, as well as spiritual. As the constitutional crisis caused by the forced departure of Piero de' Medici worsened, Savonarola propelled himself into the political arena, marrying prophetic yearning with republican traditions. The friar laid the foundation for this marriage in a series of principles: "that you fear God and seek the light of His grace...that no citizen should seek to be first or superior to the others but [all] should be content, each within his own degree and limit, as I have said...that the angels and the blessed are in Paradise, each within the limits God has given him, without seeking more beyond; in this

\footnotetext{
${ }^{30}$ Savonarola, Aggeus, Sermon XIII, 153.

${ }^{31}$ Savonarola, Aggeus, Sermon XIII, p. 153.

${ }^{32}$ Savonarola, Psalms, Sermon III, pp. 69-70

${ }^{33}$ While his historical work on Savonarola is superb, I think that Donald Weinstein confuses matters by classifying Savonarola's "post-Charles" apocalypticism as "postmillenarian." Weinstein does this because he sees Savonarola as placing "the age of regeneration within historical time, before the Second Coming and the Last Judgment." Based on my review of Savonarola's sermons, it is not at all clear to me that he can be so easily classified. First, as Weinstein himself notes, while Savonarola urges Florentines toward spiritual reform, he does not think that human action alone can bring about the millennium. Divine intervention is still necessary. This intervention will come in the form of apocalyptic tribulations and violence. This narrative already separates Savonarola's message from those commonly classified as postmillennial or postmillenarian. Second, in the sermon from which I quote at the end of the paragraph, it seems clear that the spiritual reform Savonarola is urging on Florence is not meant to establish the city as a millennial kingdom right away. Rather, it is to guarantee penitent Florentines some protection from imminent apocalyptic violence. A fully realized millennial kingdom may only be achieved, Savonarola seems to be suggesting, after a period of tribulation. See: Weinstein, Savonarola and Florence, 165-6; Savonarola, Psalms, Sermon III, 69-70.
} 
way you would be an ordered city like the celestial one." 34 He urged Florentines to adopt a holy republic, modeled on the Venetian constitution ${ }^{35}$ and with the Great Council at its heart. ${ }^{36}$ While Savonarola was not the only voice that gave form to the constitution of 1494, he was responsible for imbuing with it sacred importance and for locating it within a divine history. ${ }^{37}$ Yet, while Florence was to be a temporal republic, it would also be spiritual monarchy, with Christ as its King. ${ }^{38}$ In practical terms, this meant that Savonarola envisioned a republican government imbued with the Christian moral purpose of stamping out sin and initiating social reform. The practice of sodomy was the first target of these reforms, as the councils eliminated fines in favor of corporal punishment or death as the price to be paid for this crime. ${ }^{39}$ This agenda of moral reform brought Savonarola support both within the council, and among Florentines more broadly. ${ }^{40}$ The legislative process was not the only way in which Savonarola and his supporters instituted their reforms. When the Great Council found itself unable to initiate the total renewal for which Savonarola had hoped, he turned to roving gangs of boys, which targeted prostitutes,

\footnotetext{
${ }^{34}$ Girolamo Savonarola, Aggeus, Sermon XXIII (December 28, 1494) in Selected, 167.

${ }^{35}$ On the strange power that the idealized image of Venice exercised on the Florentine political imagination, see: J.G.A. Pocock, The Machiavellian Moment: Florentine Political Thought and the Atlantic Republican Tradition, $2^{\text {nd }}$ edn. (Princeton: Princeton University Press, 2003), 99-103. As Pocock points out, part of the appeal of the Venetian constitutional model might have been its very ambiguity. To some, it was the paradigmatic mixed government, while to others it was an unapologetic aristocracy.

${ }^{36}$ The Great Council was a sovereign legislature comprised of approximately 3,500 citizens whose membership was determined based on whether a citizen himself, or his father, grandfather, or great-grandfather had held, or had been drawn for, a seat in one of the three main executive offices of the government. This body had power over elections, taxes, and city finances. For a more detailed account of the political reforms of this period, see: Najemy, History of Florence, 381-90.

${ }^{37}$ Najemy, History of Florence, 394.

${ }^{38}$ Savonarola, Aggeus, Sermon XXIII, 171.

${ }^{39}$ Najemy, History of Florence, 395.

${ }^{40}$ It is difficult to estimate the extent of this support. As Lorenzo Polizzotto rightly points out, contemporary estimates of the size of the crowds at Savonarola's sermons cannot be taken as indicators of the extent of the friar's support. One cannot assume that attendance at a sermon is necessarily an indicator of support for the religious and political ideas advanced by the friar. We do have an idea of the support that Savonarola had within the Great Council. In December 1494, there were approximately 400 Savonarolans in the Council, accounting for about oneninth of total members. Yet, these estimates may understate the influence Savonarola's supporters had over legislation. As Polizzotto explains, Savonarola had built up a lot of good will when his prophecies were seen to have been fulfilled and when he helped shape the new government. He also had the support of some Medicean factions, whom he had intervened to protect after Piero was ousted. Finally, there were numerous gifted politicians in the Savonarolan ranks who garnered substantial support from different groups. See: Lorenzo Polizzotto, The Elect Nation: The Savonarolan Movement in Florence 1494-1545 (Oxford: Clarendon Press, 1994), 12-17.
} 
homosexuals and the wealthy, urging them toward spiritual reform. ${ }^{41}$ These very effective groups ritually enacted the spiritual purification that Savonarola had promised would ready the city for apocalyptic tribulations. Through political and moral reform, Savonarola and his supporters were determined that Florence be transformed into a holy republic, the New Jerusalem required for the fulfillment of God's apocalyptic plans.

This agenda of political transformation reveals an interesting ambiguity around the question of agency in Savonarola's apocalyptic thought. In keeping with Christian doctrine, Savonarola casts God as the primary agent of apocalyptic transformation. The friar is often at pains to stress that he is merely God's messenger. Referring to his early prophecies of apocalyptic tribulation, he stresses, "Not I, but God predicted it to you." ${ }^{42}$ Yet this role of mediator is more central to the apocalyptic drama than Savonarola sometimes suggests. He explains, "if God had not enlightened me, you would not have been enlightened through my many sermons, and you have been enlightened more exclusively than any other place." ${ }^{.43}$ Just as Florentines have been singled out for a special role in the Apocalypse, Savonarola is the chosen agent of God, capable of enlightenment so that he in his turn may enlighten. While the primary apocalyptic agent may be God, Savonarola is hardly a mere messenger. He sees himself as a father and a shepherd to a penitent and redeemed Florence. ${ }^{44}$ But it is in Savonarola's maternal metaphors that one gets the fullest and most interesting glimpse of the friar's conception of his own role in a renewed and politically transformed Florence. He asks: "Florence, am I also not to

\footnotetext{
${ }^{41}$ Violence seems to have been rare in these encounters. Shaming and the threat of public exposure appear to have been the main weapons deployed by these groups of boys. Richard Trexler suggests: "Though the friar recognized the boys' very potential for violence deterred immorality, he counted on less violent inducements: the threat of official action, the shame perpetrators felt when they behaved immorally in the presence of children, and most significant, the example that the boys showed adults. In perfect marching order, small bands of innocents moved from place to place with saintly manners and dress, impressing their own innocence upon their elders." See: Richard C. Trexler, Public Life in Renaissance Florence (New York: Academic Press, 1980), 475.

${ }^{42}$ Savonarola, Haggai, Sermon I, 89.

${ }^{43}$ Savonarola, Haggai, Sermon I, 89.

${ }^{44}$ Savonarola, Haggai, Sermon I, 91-2.
} 
you like a mother to her little child? I have suffered and suffer many pains and many afflictions to give you birth and to lead you to Christ. I have also been like your wet-nurse in raising you and counseling you about what is good for you and about your health." ${ }^{, 5}$ Thus, while he could never abandon a commitment to God as an omnipotent agent in the apocalyptic drama, Savonarola nonetheless carves out a central role for himself in the tribulations and renewal of Florence.

In conceptualizing this as a "Savonarolan moment," ${ }^{, 4}$ I do not mean to suggest that the apocalyptic enthusiasm that captured the Florentine imagination was completely defined by the spiritual and political aspirations of a single man or bounded by the very brief period between the beginning of Savonarola's apocalyptic preaching in 1490 and his execution eight years later. Rather, I am drawing on J.G.A. Pocock's theorization of a "moment" in general and "the Machiavellian moment" of republican founding in particular. Pocock asks us to interpret the Machiavellian moment in two ways. The first is rhetorical and experiential:

It is asserted that certain enduring patterns in the temporal consciousness of medieval and early modern Europeans led to the presentation of the republic, and the citizen's participation in it, as constituting a problem in historical selfunderstanding, with which Machiavelli and his contemporaries can be seen both explicitly and implicitly contending. It became crucial in their times and remained so, largely as a result of what they did with it, for two or three centuries afterwards. Their struggle with this problem is presented as historically real, though as one selected aspect of the complex historical reality of their thought; and their 'moment' is defined as that in which they confronted the problem grown crucial. $^{47}$

\footnotetext{
${ }^{45}$ Savonarola, Haggai, Sermon I, 92-3.

${ }^{46} \mathrm{I}$ am borrowing the term from Marcia L. Colish, who is of course playing on J.G.A. Pocock's "Machiavellian moment." See: Marcia L. Colish, "Republicanism, Religion, and Machiavelli's Savonarolan Moment," Journal of the History of Ideas 60, no. 4 (1999): 597-616.

${ }^{47}$ Pocock, Machiavellian Moment, vii-viii.
} 
Here, a "moment" refers to the manner in which the problem of the republic's instability within time "made its appearance." ${ }^{48}$ The relationship between the republic and its citizens is presented "as constituting a problem in historical self-understanding." However, the manner in which the these problems make their appearance is not simply a reflection of "historical reality"; rather, it is in itself "historically real."

Nevertheless, Pocock seems at pains to distinguish between the rhetorical and experiential qualities of the Machiavellian moment and "the problem itself." In its second sense, then, the Machiavellian moment is:

A name for the moment in conceptualized time in which the republic was seen as confronting its own temporal finitude, attempting to remain morally and politically stable in a stream of irrational events conceived as essentially destructive of all systems of secular stability. In the language which had been developed for the purpose, this was spoken of as the confrontation of 'virtue' with 'fortune' and 'corruption' and the study of Florentine thought is the study of how Machiavelli and his contemporaries pursued the intimations of these words. ${ }^{49}$

Here, a moment is the historical point at which the republic is threatened with collapse. The early sixteenth century in Florence was one such moment, though not the only one. This second interpretation of a moment, however, is intimately bound to the first. The historical circumstance of the republic at a given point in time is mediated through the language of "virtue," "fortune," and "corruption." The "problem itself" can never be fully separated from the manner of its presentation. ${ }^{50}$

Similarly, when I use the term "Savonarolan moment," I mean to describe both the historical point at which an apocalyptic transformation of Florence seemed possible in the late fifteenth through early sixteenth centuries and the manner in which this possibility "made its

\footnotetext{
${ }^{48}$ Pocock, Machiavellian Moment, vii.

${ }^{49}$ Pocock, Machiavellian Moment, viii.

${ }^{50}$ The discussion in the previous two paragraphs draws on the analysis of Helge Jordheim, "Conceptual History Between Chronos and Kairos-The Case of 'Empire," Redescriptions: Yearbook of Political Thought and Conceptual History 11 (2007), eds. K. Lindroos and Kari Palonen: 116-8.
} 
appearance" and was presented. The invasion of Charles VIII, for instance, appears against the backdrop of an apocalyptic imaginary that expected an imminent end to the known world. The historical moment of the invasion is also rhetorically and imaginatively constituted as a sign that this transformation is now at hand. Like the Machiavellian moment, the Savonarolan moment is an attempt to find meaning and understanding in the face of radical contingency. ${ }^{51}$ That is, both wrestle with the combination of political indeterminacy, conditionality, and uncertainty. ${ }^{52}$ Political outcomes like institutional corruption or invasion by outside forces could have been different. These outcomes are also conditional on a host of other factors, many of which we do not understand. This makes it difficult to predict or even explain political outcomes. In the face of these difficulties, we are left with the paralyzing sense that many of the events which shape our collective lives are underdetermined. The Machiavellian and Savonarolan moments grapple differently with this kind of radical contingency. The former seeks to restore the virtuous principles of the republic within secular time and to shore up the polity against the prospect of future corruption. The latter seeks an apocalyptic break with secular time and to prepare the polity to take a leading role in bringing history to a close. ${ }^{53}$

Just as Machiavelli was only "one of a number of greater and lesser men engrossed in the common pursuit" of republican founding, Savonarola was only one of many figures captivated by the apocalyptic imaginary. His eponymous moment both predated and survived him. The friar's apocalyptic message took form in the context of a much larger revival of biblical prophecy in Italy. Much of this revival consisted of a renewed interest in the apocalyptic

\footnotetext{
${ }^{51}$ Pocock, Machiavellian Moment, vii-viii.

${ }^{52}$ I draw this three-part understanding of contingency from Andreas Schedler, who argues that indeterminacy, conditionality, and uncertainty are the three conceptual pillars of "the semantic architecture of "contingency." See: Andreas Schedler, "Mapping Contingency," in Political Contingency: Studying the Unexpected, the Accidental, and the Unforeseen, eds. Ian Shapiro and Sonu Bedi (New York: New York University Press, 2007), 70.

${ }^{53}$ Savonarola had republican commitments himself, to be sure, but his vision of a republican polity was never an end in itself. Rather, it was the necessarily worldly preparation for a cosmic transformation.
} 
prophecies of Joachim of Fiore, a twelfth-century Calabrian abbot, who proposed a Trinitarian model of history in which humankind would be bought to full fruition after a period of false leadership by a priestly Antichrist and apocalyptic tribulations. ${ }^{54}$ Joachimism had been nurtured in late medieval Florence and was still very much in circulation in the late fifteenth century, as can be seen in the outpouring of Joachite prophecy during the approach of Charles VIII's forces. ${ }^{55}$ As Marjorie Reeves, a prominent Joachim scholar notes, "the Joachimist marriage of woe and exaltation exactly fitted the mood of late fifteenth century Italy," where the humanist golden age was confronting widespread apocalyptic expectation. ${ }^{56}$ While Savonarola was not a close follower of Joachim and lacked the latter's sophisticated understanding of sacred history, the friar did draw on the well-established Joachimist "juxtaposition of tribulation and renewal," as well as the prophecies of a Second Charlemagne that had developed among the Calabrian abbot's more recent followers. ${ }^{57}$

Savonarola was also by no means the only apocalyptic preacher in late fifteenth century Florence. When contemporary chronicler Piero Parenti noted the growth of terrifying apocalyptic preaching in Florence, he was not referring to Savonarola, but rather to the Franciscan Domenico da Ponzo. ${ }^{58}$ In this climate of apocalypticism, preachers vied for audiences. Those offering milder fare saw their crowds dwindle, "a fate which apparently befell

\footnotetext{
${ }^{54}$ On the role of the Antichrist in Joachim's thought, see: Bernard McGinn, Antichrist: Two Thousand Years of the Human Fascination with Evil (New York: Columbia University Press, 2000), 135-142. On Joachim's thought in its fullest form, see: Marjorie Reeves, Joachim of Fiore and the Prophetic Future (New York: Harper Torchbooks, 1976).

${ }_{56}^{55}$ Reeves, Joachim of Fiore, 88.

${ }^{56}$ Marjorie Reeves, The Influence of Prophecy in the Later Middle Ages: A Study in Joachimism (Notre Dame: University of Notre Dame Press, 1993), 431.

${ }^{57}$ Reeves, Joachim of Fiore, 89. There is little evidence that Savonarola was well-read in the works of Joachim or his followers. At times, the friar went out of his way to distance himself from a connection to Joachim, perhaps because the church hierarchy saw the latter as having a dangerously revolutionary potential. Savonarola's engagement in worldly affairs also distances him from Joachim, who seems to have been content constructing elaborate prophetic conceptions of sacred history. Nevertheless, Marjorie Reeves concludes that despite these differences, "there can be little doubt that [Savonarola] belonged within the [Joachimite] prophetic tradition." Reeves, Joachim of Fiore, 90. See also: Weinstein, Savonarola and Florence, 95-6, 159, 175.

${ }^{58}$ Piero Parenti, as quoted in Najemy, History of Florence, 375.
} 
the preachers of Santo Spirito and Santa Croce as well as the former Medici favorite, Fra Mariano. The message of flagello and repentance was the order of the day." 59 Florence was being whipped up into a state of semiotic arousal, wherein everything became a sign, a meaningful message about how the apocalyptic drama would unfold. ${ }^{60}$ When a lightning bolt struck the cathedral shortly before the death of Lorenzo de' Medici in April 1492, Savonarola interpreted the event as a sign of an imminent divine scourge. Fra Domenico went even further, giving Florentines an August deadline to change their ways. If Florence did not repent, the streets would be rivers of blood. ${ }^{61}$ Even Machiavelli concluded in retrospect that the lightning damage had been a sign that Lorenzo's "death would lead to the greatest calamities."62 Savonarola was but one influential voice among many, drawing out the signs of God's imminent irruption into human history.

Savonarola's message also drew from well-established older conceptions of Florentine identity. The notion of Florence as an elect nation with a special place in sacred history had been well-developed in previous centuries. In the first written history of Florence, the thirteenthcentury Chronica de origine civitatis, the city's special destiny is connected to its Roman origins, its position as a parva Roma, or "little Rome."63 The Chronica also suggests that Florence had previously been reborn from the rubble of a divine scourge that had happened five hundred years after her founding. ${ }^{64}$ While in the Chronica the city is rebuilt by the Romans, in a fourteenth century account the Emperor Charlemagne is the agent of this rebirth. Here we see the origins of

\footnotetext{
${ }^{59}$ Weinstein, Savonarola and Florence, 126.

${ }^{60}$ I am borrowing the term 'semiotic arousal' from Richard Landes, "Roosters Crow, Owls Hoot: On the Dynamics of Apocalyptic Millennialism" in War in Heaven/Heaven on Earth: Theories of the Apocalyptic, eds. Stephen D. O'Leary and Glen S. McGhee London: Equinox, 2005), 33.

${ }^{61}$ Weinstein, Savonarola and Florence, 127.

${ }^{62}$ Niccolò Machiavelli, The History of Florence, 8.36 in The Chief Works and Others, vol. 3, trans. Allan Gilbert (Durham: Duke University Press, 1989), 1434.

${ }^{63}$ Weinstein, "The Myth of Florence," 21.

${ }^{64}$ Weinstein, "The Myth of Florence," 21.
} 
the linked destinies of France and Florence in apocalyptic prophecy. By the late fourteenth century, sources indicate that the city ceases to be a little Rome and assumes a special apocalyptic destiny in her own right. Various radical religious elements, furiously reworking Joachite ideas to suit the needs of a divinely chosen city, kept these prophecies alive. And, as Donald Weinstein has shown, these prophetic elements were blended with conceptions of good government into "a single vision which seems to have functioned both as a model of a civic ethos and a promise of ultimate rewards." ${ }^{65}$ It is this history of Florentine self-identity, at once prophetic and republican, that inflects Savonarola's later apocalyptic sermons.

Despite these connections to established prophetic traditions and conceptions of Florentine self-identity, it might still be tempting to see the Savonarolan moment as a marginal or fringe reaction to what would retrospectively be called the Renaissance. Such a conclusion would be misguided. The Savonarolan moment, particularly in its hopes for an apocalyptic rebirth, participated in and drew from the humanism that has come to define this period in Florentine history. The notion of an enlightened people emerging from a period of darkness and ushering in a new age blended easily with the Savonarolan apocalyptic imaginary. Florentine exceptionalism lay at the center of the humanist conception of the city as a special place where history, culture, and art flourished as they could nowhere else. ${ }^{66}$ Savonarola received broad support from humanist philosophers like Pico della Mirandola, Oliviero Arduini, and Marsilio Ficino. ${ }^{67}$ The latter proclaimed Savonarola a divine agent whose prophecies had been fulfilled

\footnotetext{
${ }^{65}$ Weinstein, "The Myth of Florence," 35.

${ }^{66}$ Weinstein, "Millenarianism in a Civic Setting," 196.

${ }^{67}$ Another reason for the close connection between Savonarola and some humanist philosophers was the friar's interest in skepticism. Savonarola arranged for a complete translation of the writings of Sextus Empiricus and showed a deep interest in classical works. The skeptics' claims about the unreliability of natural knowledge suited Savonarola's prophetic cause. He argued, often with philosophical sophistication, that the only reliable knowledge was that provided by revelation. See: R.H. Popkin, "Savonarola and Cardinal Ximines: Millenarian Thinkers and Actors at the Eve of the Reformation," in Millenarianism and Messianism in Early Modern European Culture, vol. 2, ed. Karl A. Kottman (Boston: Kluwer, 2001), 16-20.
} 
and even welcomed Charles VIII to Florence with an oration proclaiming the king as a second Charlemagne. ${ }^{68}$ Ficino later rejected Savonarola, but he did so within the apocalyptic imaginary — denouncing the friar as the Antichrist, who had led Florence astray. ${ }^{69}$

While this philosophical following demonstrates that Savonarola's messages resonated with learned humanists, it is in the paintings of the period that we can most clearly see how the friar's apocalyptic preaching drew on and contributed to a shared imaginary. Sandro Botticelli's connections to Savonarola have been well-established by art historians. ${ }^{70}$ The artist was a devout follower of the friar and even threw some of his own paintings in one of the Savonarola's bonfires of the vanities. Botticelli's Mystic Nativity (1500/1) (see Figure 1) bears an inscription filled with apocalyptic anxiety and hope: "I Sandro painted this picture at the end of the year 1500 in the troubles of Italy in the half time after the time according to the eleventh chapter of St John in the second woe of the Apocalypse in the loosing of the devil for three and a half years. Then he will be chained in the twelfth chapter and we shall see him trodden down as in this picture.” ${ }^{, 71}$ While Botticelli's Crucifixion (1498-1500) (see Figure 2) does not offer a similar inscription, it renders in visual and visceral form the scourge so often promised by Savonarola. Behind the crucified Jesus are fiery brands shooting downward from the skies and the city of Florence, bathed in light and partially protected from tribulation. ${ }^{72}$

\footnotetext{
${ }^{68}$ Nancy Bisaha, Creating East and West: Renaissance Humanists and the Ottoman Turks (Philadelphia: University of Pennsylvania Press, 2006), 41. Bisaha does an excellent job tracing the medieval roots of a sustained interest in Charlemagne in Renaissance Europe, particularly among humanists.

${ }^{69}$ Marsilio Ficino, Apologia contra Savonarolam, in Selected Writings, 355-9.

${ }^{70}$ See, for instance: Rab Hatfield, "Botticelli's Mystic Nativity, Savonarola and the Millennium," Journal of the Warburg and Courtauld Institutes 58 (1995): 89-114.

${ }^{71}$ The translation of the Greek is from Weinstein, "Myth of Florence," 15.

${ }^{72}$ Weinstein, "Myth of Florence," 16-17.
} 


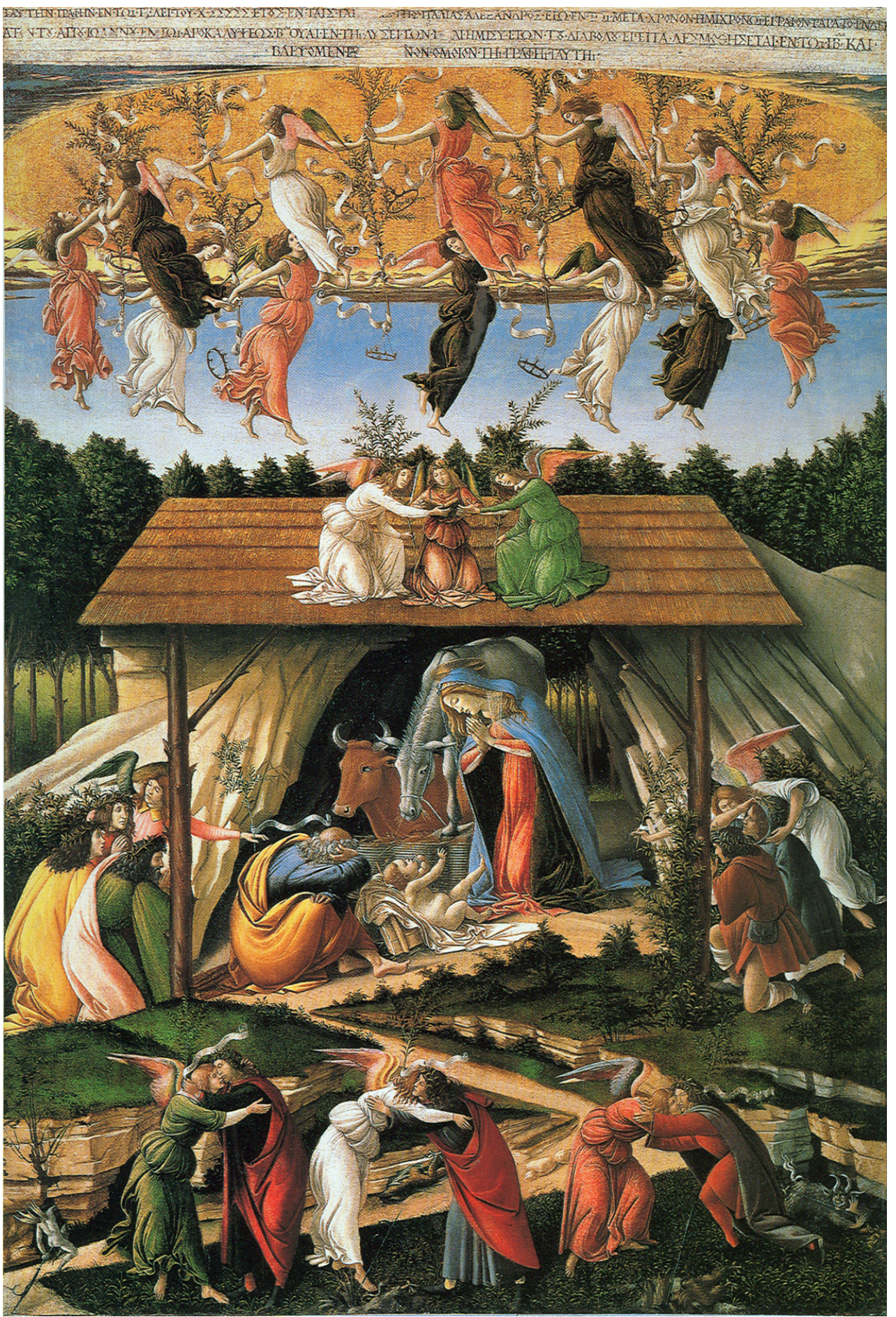

Figure 1: Sandro Botticelli, Mystic Nativity, 1500-1501. The National Gallery, London. 


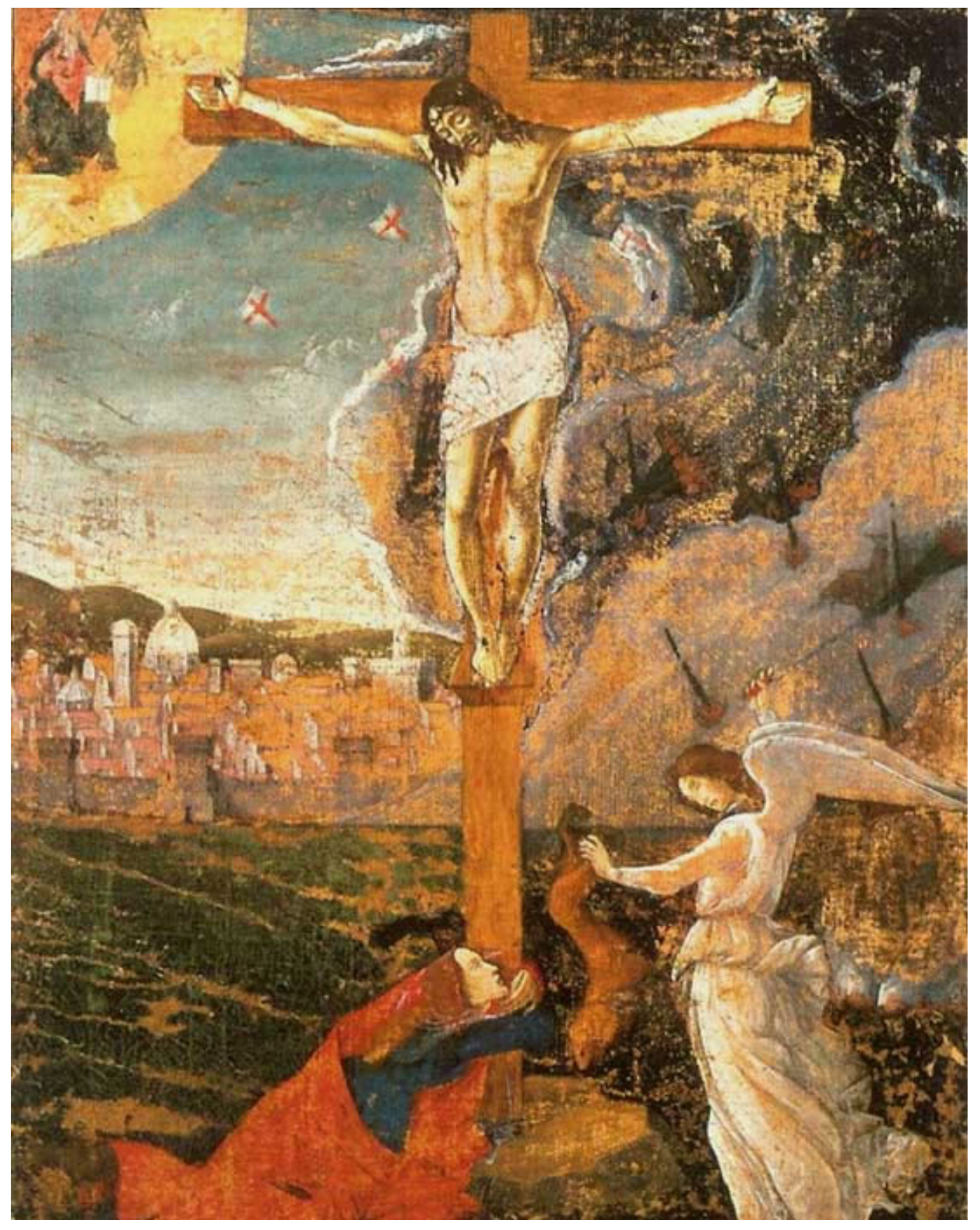

Figure 2: Sandro Botticelli, Crucifixion, 1497-8. Fogg Museum of Art, Harvard University. 
Even more visceral renderings of the apocalyptic imaginary can be found in Signorelli's apocalypse at Orvieto (1499-1502) (Figures 3 and 4). The multi-panel sequence visually interprets the apocalyptic events foretold in Revelation. One panel depicts the Antichrist pausing mid-sermon to receive intimate instructions from the devil. In another panel, winged demons torment the damned before forcing them into the fiery pits of hell. This remarkable sequence blends the typical Renaissance attention to the glory of the human form with shocking divine violence. These images speak to a Renaissance to which scholars give too little attention—one captured by an apocalyptic imaginary that saw totalizing divine violence as a prerequisite for spiritual rebirth.

Savonarola was executed in 1498 by the government which he helped to shape. Accused of false prophecy and even heresy, he was publicly burned alive. ${ }^{73}$ Yet the apocalyptic imaginary to which he gave an enduring voice took on an independent life. Signs of the apocalypse were being spotted everywhere in Italy, from the anxiety about the arrival of the Antichrist in 1500 to apocalyptic interpretations of the sack of Rome in 1527. Savonarola's apocalyptic prophecy imposed a divine order on the crisis and contingency that characterized Florentine politics at the end of sixty years of Medici rule. He held out the promise of an escape for a small elect from the frightening unpredictability of power politics. Savonarola did not offer the repentant complete protection from God's totalizing apocalyptic violence, but rather the promise that their suffering would be made meaningful through an apocalyptic rebirth. Drawing on the hopes and fears of Florentines, Savonarola rendered imaginable that most unimaginable of

\footnotetext{
${ }^{73}$ Savonarola had made a number of enemies in the mid to late 1490 s, not the least of whom was Pope Alexander VI, who excommunicated the friar. In 1498, tensions between Savonarolan and anti-Savonarolan factions in Florence came to a head. Savonarola was arrested and subsequently admitted under torture that his prophecies were false. He was then questioned by Alexander's emissaries and condemned as a heretic before being hanged and burned alive with two of his associates.
} 


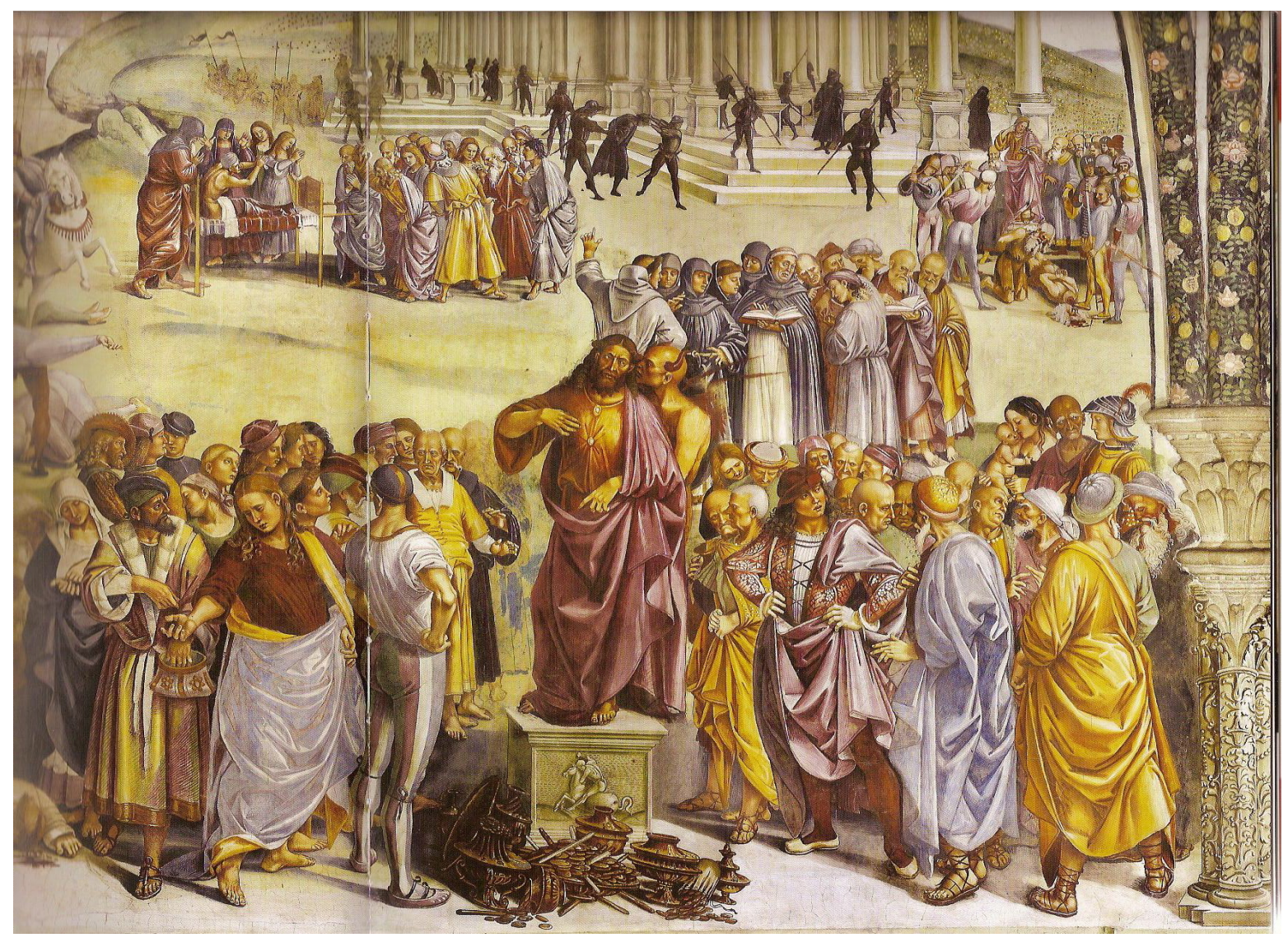

Figure 3: Luca Signorelli, Apocalypse Sequence, 1499-1502. Cappella di San Brizio, Orvieto. 


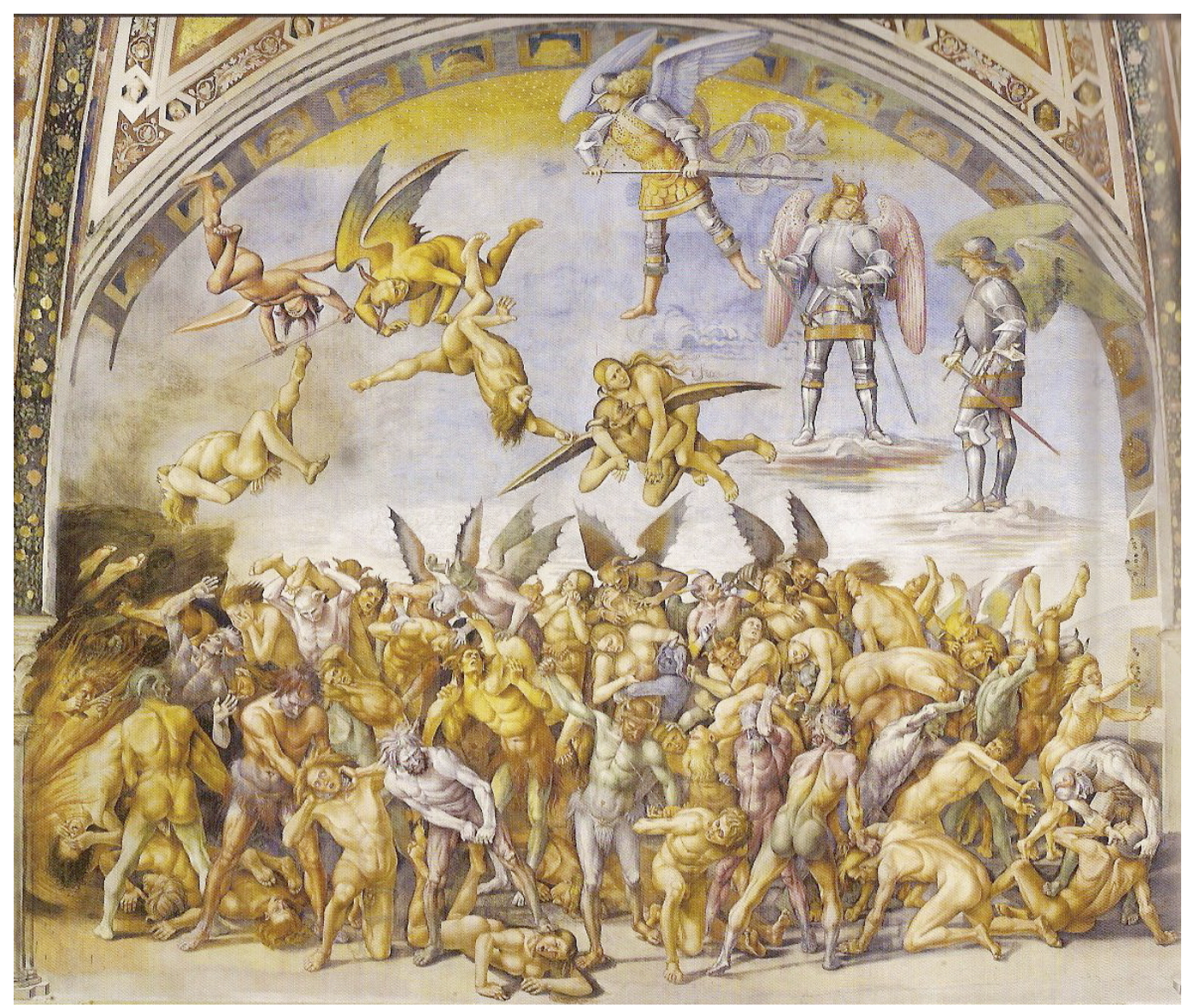

Figure 4: Luca Signorelli, Apocalypse Sequence, 1499-1502. Cappella di San Brizio, Orvieto. 
events - the irruption of God into secular time. In so doing, he channeled an apocalyptic imaginary that would continue to exert its power over Italy long after his death.

\section{Flirting with Apocalypse: Machiavelli's Savonarolan Moment}

In this section of the chapter, I try to demonstrate that this Savonarolan moment of apocalyptic enthusiasm had a profound effect on Machiavelli. Yet perhaps the possibility of such an influence might strike some as strange. Is Machiavelli not the theorist (even celebrator) of naked and violent power politics? Is he not the first truly modern political theorist, an unabashed realist who seeks a clean break from medieval religious statecraft? ${ }^{74}$ Would he not be suspicious of or condescending toward Savonarola's claims that he received knowledge through revelation rather than through sober assessment of political reality?

As long as we maintain these caricatures of these two men, one as a politically impotent and utopian friar and the other as a modern theorist of power, the only possible way to conceptualize Machiavelli's engagement with Savonarola is to see it as dismissive and even contemptuous. ${ }^{75}$ There is textual evidence that can be marshaled to support such an interpretation, but it is by no means unambiguous. By revisiting what appear to be the two

\footnotetext{
${ }^{74}$ This claim is made by a variety of political theorists, with vastly different intellectual agendas, seeking to construct a grand narrative of the history of political thought. See, for instance: Strauss, Thoughts on Machiavelli (Chicago: University of Chicago Press, 1958); Leo Strauss, "The Three Waves of Modernity," in Hilail Gildin (ed.) An Introduction to Political Philosophy: Ten Essays by Leo Strauss (Detroit: Wayne State University Press, 1989), 81-98; Harvey C. Mansfield, Machiavelli's Virtue (Chicago: University of Chicago Press, 1996); Sheldon S. Wolin, Politics and Vision: Continuity and Innovation in Western Political Thought, expanded edn. (Princeton: Princeton University Press, 2004), 175-213.

${ }^{75}$ Marcia L. Colish offers one of the more bold and interesting versions of this argument (and one that tends less to caricature than some others). Colish claims that, contrary to a widely held scholarly opinion, Machiavelli is not antiChristian. Rather, in every passage in which Machiavelli appears to be making an argument against Christianity, he is actually trying to undermine Savonarola. The reason for this, Colish suggests, is that Machiavelli wanted to strongly defend his own republicanism against the Savonarolan alternative (both of which were themselves alternatives to a version of republicanism espoused by the ottimati. I find Colish's position a difficult one to support, given both the variety of Machiavelli's statements on Savonarola and the depth and complexity of his views on Christianity. See: Colish, "Machiavelli’s Savonarolan Moment," 600-1.
} 
strongest instances of Machiavelli's negative assessment of Savonarola, I aim to open space to consider the way in which the hopes of the friar became the exhortations of the political theorist.

We find Machiavelli's most apparently negative assessment of Savonarola in a letter he wrote to Ricciardo Becchi, the Florentine ambassador to Rome, on March 9, 1498. In June of the previous year, Pope Alexander VI, whom Savonarola had "repeatedly denounced as the embodiment of a corrupt and fallen church," had excommunicated the friar and temporarily silenced him. ${ }^{76}$ However, the defiant Savonarola resumed preaching in February 1498, once again drawing large crowds. Machiavelli attended two of the friar's sermons on Exodus. According to his report, the first of these reassured Savonarola's followers that while they, like the Israelites, were being oppressed, God was on their side and their numbers would multiply. The second suggested that there was an unnamed tyrant in Florence who was persecuting Savonarola and his followers. Machiavelli provides Becchi with an account of the content of these sermons, as well as a description of their effect on the friar's audiences. Machiavelli is particularly concerned with a shift that occurred in Savonarola's sermons-from fear of an unnamed potential tyrant in Florence to sharp criticism of the Pope. This shift, argues Machiavelli, is purely opportunistic. The friar has simply "changed coats" and, in Machiavelli's judgment, he "acts in accordance with the times and colors his lies accordingly." 77 One could see this assessment in an entirely negative light, as a condemnation of the friar's blatant hypocrisy. Yet I think such a judgment is too hasty. Elsewhere, Machiavelli sees an ability to change with the times as a rare virtù. ${ }^{78}$ The ability to "color" one's "lies accordingly," and to do so as successfully as Savonarola has, suggests some skill in cultivating appearances, which is

\footnotetext{
${ }^{76}$ Najemy, History of Florence, 397.

${ }^{77}$ Letter from Niccolò Machiavelli to Ricciardo Becchi, 9 March 1498, in Machiavelli and His Friends: Their Personal Correspondence, trans. James B. Atkinson and David Sices (DeKalb: Northern Illinois University Press, 2004), 10.

${ }^{78}$ This is a recurrent theme in The Prince.
} 
also a virtù that Machiavelli deems praiseworthy. ${ }^{79}$ Furthermore, the detail and analysis that Machiavelli provides in the letter suggests that he takes Savonarola seriously as an important political actor.

At the very least, some might suggest that Machiavelli's assessment reduces Savonarola's prophecy to the status of mere lies. It is certainly true that Machiavelli denies Savonarola's claim to a prophetic status here. In other works, however, he was more restrained. For instance, in the First Decennale (1504), he states simply that Savonarola was "inspired with heavenly virtù." ${ }^{\prime \prime}$ Focusing more on the factional outcomes of Savonarolan rhetoric than on its truth claims, Machiavelli nonetheless accepts the friar's heavenly inspiration as a given. In the Discourses on Livy (1516-1518?), Machiavelli addresses the question more overtly. He recounts that the people of Florence were convinced of Savonarola's prophetic status, believing that the friar spoke with God. Rather than denying this claim, or reducing it to a lie, Machiavelli refrains from judgment. While he notes that there was no evidence to support Savonarola's claim, he also writes that he does not "wish to judge whether it is true or not, because one should speak with reverence of such a man." ${ }^{, 81}$ There is a remarkable echo here of Machiavelli's earlier assessment of Moses in The Prince, whose prophetic status is not up for debate. We must simply admire Moses "for that grace which made him deserving of speaking with God." ${ }^{\prime 2}$ Thus, in Machiavelli's later discussions of Savonarola in The First Decennalle and The Discourses we see a reluctance to pass judgment and an openness to the possibility that his claims to prophecy

\footnotetext{
${ }^{79}$ Niccolò Machiavelli, The Prince, trans. Harvey C. Mansfield (Chicago: University of Chicago Press, 1998), ch. 18, 68-71.

${ }^{80}$ Niccolò Machiavelli, First Decennale, in Chief Works and Others, vol. 3, lines 157-9, 1448. Allan Gilbert translates "virtù" as "vigor" in this passage.

${ }^{81}$ Niccolò Machiavelli, Discourses on Livy, trans. Harvey C. Mansfield and Nathan Tarcov (Chicago: University of Chicago Press, 1998), I.12, 36.

${ }^{82}$ Machiavelli, Prince, ch. 6, 22.
} 
might be more than just "lies." Seen in this light, Machiavelli's apparently negative assessment of Savonarola in the letter to Becchi is more complex than it initially seems.

Fifteen years after his letter to Becchi, Machiavelli considers Savonarola once again in The Prince. Here, Savonarola is the paradigmatic unarmed prophet. While the friar successfully used his powers of prophetic persuasion to establish "new orders" in Florence, he had no recourse to violent force when his persuasive powers expired. While people may be easily persuaded at first, it is "difficult to keep them in that persuasion. And thus things must be ordered in such a mode that when they no longer believe, one can make them believe by force." 83 Unfortunately, Savonarola "had no [way to hold] firm those who had believed nor for making unbelievers believe." ${ }^{84}$ It is certainly possible to see Machiavelli's assessment here as a wholly negative one that suggests a fundamental lack of political acumen on Savonarola's part. Yet, once again, I think Machiavelli's assessment is more complex. Savonarola is in the best of company in this chapter of The Prince, grouped alongside the great founding legislators of myth and history-Moses, Cyrus, Theseus, and Romulus. Machiavelli is recognizing Savonarola as a (re)founder of a state, a role that the Florentine thinker holds in the highest regard. Savonarola's ultimate goal is not in question here. Rather, it is only his mode of action that opens him to criticism. He has no other means of maintaining himself than by keeping the support of the masses, who are by nature variable. ${ }^{85}$ Seen in this way, Machiavelli's famous assessment of Savonarola in The Prince is less a condemnation of the friar's lack of political skill, and more a tribute to what this refounder tried to do and a lamentation of his failure. These reassessments of Machiavelli's most seemingly negative judgments of Savonarola open a space in which we can consider the potentially vital connection between the friar and the political theorist.

\footnotetext{
${ }^{83}$ Machiavelli, Prince, ch. 6, 24.

${ }^{84}$ Machiavelli, Prince, ch. 6, 24. Mansfield translates the passage as "had no mode for holding firm."

${ }^{85}$ Thierry Ménissier, "Prophétie, politique et action selon Machiavel," Les études philosophiques 66 (2003): 305.
} 
This connection is on fullest display in the final chapter of The Prince, "An Exhortation to Seize Italy and to Free Her from the Barbarians." This is a chapter that has posed numerous problems for those wanting to cast Machiavelli solely as an empirical and detached political analyst. The exhortation's passionate and biblical language suggests an author whose apparent pragmatism has been overcome by a strange world of prophetic signs. Machiavelli begins the chapter by explaining that he has now reached a point in the work where he must consider "whether in Italy at present the times have been tending to the honor of a new prince, and whether there is matter to give opportunity [occasione] to someone prudent and virtuoso to introduce a form that would bring honor to him and good to the community of men." 86 The Florentine thinker wastes no time in offering his answer: "it appears to me that so many things are tending to the benefit of a new prince that I do not know what time has ever been more apt for it. ${ }^{\prime 87}$ This time, suggests Machiavelli, is an extraordinary one, an occasione that calls for action. Historically, 1513 was indeed a period of crisis and upheaval in Florentine politics, but perhaps not one of any apparent extraordinary significance. The Medici had been brought back to power in the previous year by some of the city's radical ottimati, aided by Pope Julius and a Spanish army. It was becoming apparent that this was not simply a return to the pre-1494 status quo, but rather "something different, more autocratic, less bound to Florentine political tradition." ${ }^{88}$ Like the period of crisis in which Savonarola wrote, Machiavelli issues his exhortation at a time when the foundations of Florentine domestic politics have been shaken and the city has found itself once again at the mercy of foreign armies. And, like the friar,

\footnotetext{
${ }^{86}$ Machiavelli, The Prince, ch. 26, 101-2. Rather than translating virtù as "virtue" and virtuoso as "virtuous", as Mansfield does in this translation, I prefer to render the words in their original Italian in order to clearly signal their central and contested place in Machiavelli's work.

${ }^{87}$ Machiavelli, The Prince, ch. 26, 102.

${ }^{88}$ Najemy, History of Florence, 414.
} 
Machiavelli turns what might otherwise have been yet another political crisis into an extraordinary moment of rupture that he hopes will inaugurate a radically new future.

Yet it is not just upheaval and uncertainty that make this the most apt time for princely intervention. Rather, it is what Machiavelli casts as the complete degradation of Italy that provides the appropriate occasione for an extraordinary and prophetic act. For the virtù of Moses to be made visible, it was necessary "that the people of Israel be enslaved in Egypt." Similarly, for the virtù of the Italian spirit to be made manifest, it is necessary "that Italy be reduced to the condition in which she is at present, which is more enslaved than the Hebrews, more servile than the Persians, more dispersed than the Athenians, without a head, without order, beaten, despoiled, torn, pillaged, and having endured ruin of very sort." 89 Here, Machiavelli is picking up a theme that he had begun developing in chapter 6, where he explains that Fortune provides virtuoso founders with an occasione for action. For Moses, Cyrus, and Theseus, this occasione consisted in finding their people devastated or dispersed. ${ }^{90}$ In his Exhortation, Machiavelli makes the shocking assertion that the suffering of Italians is even worse than that of the Israelites, Persians, and Athenians. It is an occasione without precedent that demands an extraordinary act.

The nature of this act is both prophetic and apocalyptic. Machiavelli is not merely calling for a great founder here. He is hoping for a redemptive prince, someone to save Italy "from these barbarous cruelties and insults" " entire chapter is suffused with the language of redemption. Like Savonarola, Machiavelli offers various signs from God that the moment for an extraordinary rebirth is at hand. Beyond the 'empirical' signs of Italy's devastation, there are the allegorical signs taken from Exodus: "the

\footnotetext{
${ }^{89}$ Machiavelli, The Prince, ch. 26, 102.

${ }^{90}$ Machiavelli, The Prince, ch. 26, 23.

${ }^{91}$ Machiavelli, The Prince, ch. 26, 102.
} 
sea has opened; a cloud has escorted you along the way; the stone has poured forth water; here manna has rained; everything has concurred in your greatness.. ${ }^{92}$ Not only do these signs indicate the existence of an extraordinary moment, they also suggest that the Italians are a chosen people, the Israelites of the Renaissance. They are an elect people — chosen to suffer so that they could be redeemed.

Lest these signs be dismissed as the accidents of a world governed by contingency, God or Fortuna must provide a prophet to explain them. Savonarola saw himself as a prophet chosen by God to interpret the signs of a coming apocalypse to a Florence undergoing a scourge and eventual rebirth. The friar offered Florentines a narrative that located the crises of the present in a Christian eschatological drama in which suffering would be redeemed in the establishment of a New Jerusalem with Christ as its king. Machiavelli attempts to draw out a prophetic figure capable of a similar interpretive endeavor. He calls for a redemptive prince who is capable of giving meaning to Italy's degradation by locating it within a redemptive eschatology in which violence and suffering are the necessary prerequisites for a collective rebirth. The "barbarous cruelties" that Italy has endured demand both a meaning and an end. It is unbearable, Machiavelli seems to be suggesting, that such suffering be yet another accident of an inscrutable Fortune. It cries out for a prophetic, and ultimately apocalyptic, interpretation.

Yet, similar to Savonarola's prophetic message, the boundary between interpreting and enacting an apocalypse is blurred here. Savonarola confuses the question of apocalyptic agency by casting himself, on the one hand, as merely a messenger who announces events that will be carried out by God and, on the other, as an agent of Florence's sacred transformation. In the final chapter of The Prince, Machiavelli puts God in the role he had assigned to Fortune in the

\footnotetext{
${ }^{92}$ Machiavelli, The Prince, ch. 26, 103. Machiavelli is citing the miracles witnessed by Moses and the Israelites as they made their way to the promised land. Note that Exodus was also a central text for Savonarola.
} 
previous chapters. God signals an occasione for apocalyptic rebirth by offering signs that the present is an extraordinary time. However, "the remainder" the redemptive prince must do himself. "God does not want to do everything, so as not to take free will from us and that part of the glory that falls to us. ${ }^{, 93}$ The redemptive prince must become an agent of the apocalyptic transformation. Machiavelli effectively destroys the line between the prophetic interpreter and the divine actor. The redemptive prince here boldly takes on the role that even Savonarola could never quite leave entirely to God - that of actually carrying out the apocalyptic transformation. His success is guaranteed both by his prophetic ability to persuade others of the truth of his interpretation and by a divine ability to enact the apocalypse.

Just as Savonarola promised spiritual as well as temporal rewards to a chosen Florence, Machiavelli offers his redeemer prince not only divine favor but also unparalleled political power, buttressed by unconditional love and obedience. He concludes: "I cannot express with what love he would be received in all those provinces that have suffered from these floods from outside; with what thirst for revenge, with what obstinate faith, with what piety, with what tears. What doors would be closed to him? What peoples would deny him obedience? What envy would oppose him? What Italian would deny him homage?"94 This is a very important, yet strikingly peculiar, promise. No longer would the support of the masses be variable. Machiavelli offers the prophetic hope of a profound human transformation that would alter the people's very nature. Like the biblical and Savonarolan apocalypses, Machiavelli's revelation ends in a millennium defined by absolute power and absolute love. This love is "a spontaneous submission to the prince's redemptive power: an acknowledgement of, and surrender to, his

\footnotetext{
${ }^{93}$ Machiavelli, The Prince, ch. 26, 103.

${ }^{94}$ Machiavelli, The Prince, ch. 26, 105.
} 
transformative omnipotence. ${ }^{.95}$ In Italy's eschaton, the people thus offer themselves up for a sacred transformation after which the absolute power of the redemptive prince is guaranteed by the absolute love of the radically altered masses. It marks an end to the contingency that defines the political world.

While this apocalyptic exhortation participates in and transforms the rhetoric of the Savonarolan moment, it seems to many to be fundamentally inconsistent with the rest of The Prince. Surely, this is just an emotional outburst from a patriotic Italian. Perhaps it was even added later with the sole purpose of gaining the favor of the newly returned Medici. ${ }^{96}$ Yet, what would it mean to take this exhortation seriously? What might we uncover if we examine it in relation to the preceding chapters? Such an examination reveals that it is not at all peculiar that The Prince should end in such an exhortation. Even more boldly, I might suggest that there hardly seems a way in which The Prince could end in anything other than an apocalypse.

As Machiavelli casts it, the purpose of The Prince is to offer illuminating historical examples and to extract from them meaningful political wisdom, or a set of rules for behavior worthy of imitation or avoidance. ${ }^{97}$ Machiavelli offers his "knowledge of the actions of great men, learned by me from long experience with modern things and a continuous reading of

\footnotetext{
${ }^{95}$ John M. Najemy, Between Friends: Discourses of Power and Desire in the Machiavelli-Vettori Letters of 15131515 (Princeton: Princeton University Press, 1993), 213.

${ }^{96}$ The status of the last chapter of The Prince is a matter of significant debate in Machiavelli scholarship. The most detailed argument for the position that the final chapter of work, along with portions of the sixth chapter, were added later is offered by Mario Martelli. He argues that these sections must have been added in 1518, in an attempt to influence Lorenzo de' Medici who, as some thought, was considering turning Florence into a formal principate. For Martelli, the chapter could only have been written when there was a hope for Italian 'redemption' via a formalization of Medici rule. However, Gennaro Sasso has decisively countered this argument by pointing out that, on Machiavelli's own terms, the time for a redemptive intervention is when Florence and Italy are at their most devastated. This makes the period of upheaval in 1513 a more likely time for Machiavelli to have issued his exhortation than 1518. See: Mario Martelli, "Da Poliziano a Machiavelli: sull'epigramma dell'Occasione e sull'occasione," Interpres 2 (1979): 230-54; Mario Martelli, "La logica provvidenzialistica e il capitolo XXVI del Principe," Interpres 4 (1982): 262-384; Gennaro Sasso, Machiavelli e gli antichi, vol. 2 (Milan: Ricciardo Ricciardi Editore, 1988), 197-276. For a more detailed and nuanced account of the positions in this debate, as well as some original contributions to it, see: Najemy, Between Friends, 177-84.

${ }^{97}$ Albert Russell Ascoli, "Machiavelli's Gift of Counsel," in Machiavelli and the Discourse of Literature, eds. Albert Russell Ascoli and Victoria Kahn (Ithaca: Cornell University Press, 1993), 220.
} 
ancient ones." He suggests that he has "thought out and examined these things with great diligence," filtering them and reducing them "to one small volume." 98 The promise here is therefore of a distillation of historical examples into general rules - a systematic study to render the apparent contingency of history and politics intelligible and useful. Initially, The Prince seems to deliver on this promise. The chapters in the first half of the work are characterized by obsessively neat and contained categories. Principalities are either hereditary or new. They are acquired through virtue, Fortune, or crime. Machiavelli is doing his utmost to keep analytical divisions precise and separate. Similarly, the lessons derived from historical and contemporary examples seem clear and categorical. Would-be conquerors must either eliminate or inhabit republics in order to hold them. "99 "Those who become princes from private individual solely by fortune become so with little trouble, but maintain themselves with much." ${ }^{100}$ In the early chapters of The Prince, Machiavelli is desperately trying to fulfill the work's initial promise to give meaning to history and render the political world intelligible by wrenching lessons from its apparent contingency.

As the work proceeds, however, this intelligibility breaks down. Rules that had previously been extracted from history and expressed with unambiguous clarity are now increasingly qualified. Machiavelli is finding it necessary to complicate generalizations and modify rules. The project of historical and political intelligibility has begun turning back on itself. ${ }^{101}$ Chapter 17 offers an illustrative example. At the heart of the chapter is an apparently unambiguous lesson-it is better for a prince to be feared than loved. Yet, as the chapter moves forward, the rule becomes more and more qualified, and ultimately less clear. After invoking

\footnotetext{
${ }^{98}$ Machiavelli, The Prince, dedicatory letter, 3.

${ }^{99}$ Machiavelli, The Prince, ch. 5, 21.

${ }^{100}$ Machiavelli, The Prince, ch. 7, 25.

${ }^{101}$ Thomas M. Greene, “The End of Discourse in Machiavelli’s 'Prince,"” Yale French Studies 67 (1984): 65.
} 
Cesare Borgia's reputation for cruelty, which brought unity and peace to the Romagna, Machiavelli goes on to suggest that the prince should nonetheless "proceed in a temperate manner with prudence and humanity." ${ }^{\prime 102}$ While the prince should make himself feared, he should do so "in such a way that if he does not acquire love, he escapes hatred." 103 The prince should deploy cruelty, but "he must abstain from the property of others."104 While cruelty toward one's people should be tempered, a prince should not be so limited when dealing with his soldiers. The "inhuman cruelty" of Hannibal should be imitated because it promoted unity and discipline. ${ }^{105}$ Not all of the rhetorical moves that Machiavelli makes in this chapter involve a qualification of its central rule. Yet the number of qualifications is suggestive of the thinker's difficulty in extracting clear guidelines from historical experience. This chapter provides an example of how Machiavelli’s “conceptual clarity becomes more visibly overgrown.",106

We can trace a similar breakdown in Machiavelli's attempt to grapple with the idea of Fortune. As a political theorist, Machiavelli has tried to render the political world intelligible and in so doing has attempted to provide the princely man of action with the knowledge necessary to deploy his virtù to pull order and glory from apparent contingency. In the final chapters of The Prince, Machiavelli turns to a focused consideration of how this might be done. To be sure, he has examined the interplay of virtù and Fortuna in earlier chapters. But, with the exception of chapter 6, which foregrounds themes and ideas developed toward the end of the work, virtù tends to be conceptualized as a kind of "enabling talent"107 and autonomy, while Fortuna is treated as a dependence on others. ${ }^{108}$ Machiavelli's reconsideration of these themes

\footnotetext{
${ }^{102}$ Machiavelli, The Prince, ch. 17, 66. Mansfield translates this passage as "proceed in a temperate mode..."

${ }^{103}$ Machiavelli, The Prince, ch. 17, 67. Mansfield translates this passage as "in such a mode that if..."

${ }^{104}$ Machiavelli, The Prince, ch. 17, 67.

105 Machiavelli, The Prince, ch. 17, 67.

${ }^{106}$ Greene, "The End of Discourse," 65.

${ }^{107}$ Greene, "Discourse on Literature," 59.

${ }^{108}$ For instance, see ch. 7 of The Prince.
} 
begins at the end of chapter 24 , where he argues that princes who have held their principalities for many years "may not accuse fortune when they have lost them afterwards." 109 Such men are not victims of Fortune, but rather of their own laziness. "Never having thought that quiet times could change (which is a common defect of men, not to take account of the storm during the calm), when later the times became adverse, they thought of fleeing and not defending themselves." ${ }^{\prime 10}$ These princes wait in expectation that their people will call them back. While this may be an acceptable course of last resort, a prince should first consider more activist remedies. For, Machiavelli warns, "one should never fall in the belief you could find someone to pick you up. Whether it does not happen or happens, it is not security for you, because that defense was base and did not depend on you. And those defenses alone are good, are certain, and are lasting, that depend on you yourself and on your virtù." 111 Once again, Machiavelli conceptualizes virtù as autonomy. However, he has provided a metaphor for the variation and contingency of Fortune that hardly renders it more intelligible. The effects of Fortune, like a storm, cannot be prevented. One may prepare for them. Yet Machiavelli does not explain how a prince might prepare to confront Fortune's unaccountable variation. Furthermore, his weather analogy suggests a completely impersonal Fortune, totally beyond human influence. ${ }^{112}$

Machiavelli attempts to dismantle this conception of Fortune in the following chapter. He intends to counter the common opinion "that worldly things are so governed by fortune and by God, that men cannot correct them with their prudence." ${ }^{113}$ He admits that he himself has been inclined to this opinion and that it is one that "has been believed more in our times because

\footnotetext{
${ }^{109}$ Machiavelli, The Prince, ch. 24, 97.

${ }^{110}$ Machiavelli, The Prince, ch. 24, 97.

${ }^{111}$ Machiavelli, The Prince, ch. 24, 97.

${ }^{112}$ Hanna Fenichel Pitkin, Fortune is a Woman: Gender and Politics in the Thought of Niccolò Machiavelli, $2^{\text {nd }}$ edn. (Chicago: University of Chicago Press, 1999), 148.

${ }^{113}$ Machiavelli, The Prince, ch. 25, 98.
} 
of the great variability of things which have been seen and are seen every day, beyond human conjecture." 114 Yet, while the sheer variability of events in his own time seems to render the political world unintelligible, Machiavelli proposes to open a space for understanding by making variation itself subject to generalization. His motives for this project, however, do not appear to derive from any sense that such variation is inherently intelligible. Rather, he seeks to preserve autonomy and free will. It is not acceptable that worldly things be governed entirely by Fortune because, if that were true, men would cease to exercise their autonomy. ${ }^{115}$ They might "not sweat much over things" and would surrender themselves to pure chance. ${ }^{116}$ If Fortune is unintelligible, men may fail to act. In order to save the free will and autonomy of men, Machiavelli judges that "it might be true that fortune is arbiter of half of our actions, but also that she leaves the other half, or close to it, for us to govern." ${ }^{117}$ Yet this hypothesis hardly makes fortune more intelligible and thus does not remedy the paralyzing effect of an absence of understanding on the possibility of political action.

Machiavelli then shifts tactics, returning to a conception of Fortune as an impersonal force. This time, however, it is a force subject to human control. He likens Fortune "to one of these violent rivers which, when they become enraged, flood the plains, ruin the trees and the buildings, lift the earth from this part, drop in another; each person flees before them, everyone yields to their impetus without being able to hinder them in any regard." ${ }^{, 18}$ Fortune seems at its most inscrutable and unstoppable when the extraordinary happens and the river floods. However, in quiet times, prudent men may prepare for these extraordinary onslaughts by building dams and dikes. Technological mastery and foresight are the tools for navigating

\footnotetext{
${ }^{114}$ Machiavelli, The Prince, ch. 25, 98.

115 Pitkin, Fortune is a Woman, 149.

${ }^{116}$ Machiavelli, The Prince, ch. 25, 98.

${ }^{117}$ Machiavelli, The Prince, ch. 25, 98.

${ }^{118}$ Machiavelli, The Prince, ch. 25, 98.
} 
fortune. Yet The Prince is laden with examples of prudent leaders who are foiled by Fortune in spite of themselves, or whose careful calculations are rendered meaningless when faced with a bold show of military force. ${ }^{119}$ Once again, Machiavelli has not made Fortune intelligible. He has explained when men should act—during calm times—but he has not adequately answered the question of how they should act.

Machiavelli attempts to answer this lingering question by offering a general rule: a prince must adapt his "mode of proceeding to the qualities of the times." 120 Men have been successful in their confrontations with Fortune by being both bold and cautious, violent and artful, patient and impetuous. Their success depends on how well their chosen course matches the quality of the times. Yet Machiavelli does not explain how we may know which trait matches any given time. One suspects this is something that may only be determined in retrospect, if even then. ${ }^{121}$ In an even more frustrating move, Machiavelli admits that man is fundamentally incapable of varying his nature with the times, "whether because he cannot deviate from what nature inclines him to or also because, when one has always flourished by walking on one path, one cannot be persuaded to depart from it." ${ }^{\text {122 }}$ Were he capable of varying his own nature, a man could vary seamlessly with the times and "his fortune would not change." 123 The importance of this impossible human variability means that the cautious and prudent builder of dams cannot always succeed. ${ }^{124}$ Indeed, here Machiavelli considers the example of Pope Julius II, who was not a cautious man but a bold one. Julius was able to match his actions with the times. However, he succeeded not because he was capable of a super-human variability, but merely because he was

\footnotetext{
${ }^{119}$ Pitkin, Fortune is a Woman, 151.

${ }^{120}$ Machiavelli, The Prince, ch. 25, 99.

${ }^{121}$ Robert Orr, "The Time Motif in Machiavelli," in Machiavelli and the Nature of Political Thought, ed. Martin Fleisher (New York: Atheneum, 1972), 199.

${ }^{122}$ Machiavelli, The Prince, ch. 25, 100.

${ }^{123}$ Machiavelli, The Prince, ch. 25, 100.

${ }^{124}$ Pitkin, Fortune is a Woman, 151.
} 
fortunate enough to die before times changed and he came to ruin. Had times changed while he was alive, "he would never have deviated from those modes to which nature inclined him" and would have come to ruin. ${ }^{125}$ Machiavelli has led himself right back to the opinion he had intended to disprove. ${ }^{126}$ Fortune remains impersonal and unintelligible, leaving men unsure whether their actions will overcome it or lead to political ruin.

Attempting to salvage this endeavor, Machiavelli concludes by personifying Fortune through yet another metaphor. Resorting once again to a general rule, Machiavelli proclaims: "it is better to be impetuous than cautious, because fortune is a woman; and it is necessary, if one wants to hold her down, to beat her and strike her down. And one sees that she lets herself be won more by the impetuous than by those who proceed coldly." 127 The metaphor of Fortune as a woman assigns to variability and contingency a nature that implies a course of action. ${ }^{128}$ Having fixed the nature of Fortune, Machiavelli has leveled the playing field somewhat. Man, with his inflexible nature, is now at less of a disadvantage. Yet the metaphor itself raises profound questions, beyond the usual ones connected to its obvious misogyny. The metaphor does not offer us an intelligible fortune. It merely suggests that brute force may sometimes contain her infinite variety. ${ }^{129}$ Without intelligibility, however, the variability of the world remains mere contingency, contained occasionally by violence but fundamentally unknowable.

Is it, then, a surprise after this agonizing struggle to bring the contingency of the political world within the realm of human understanding that The Prince ends in an apocalyptic exhortation? If Fortune cannot be understood by rules, or calculations, or even metaphors, then even prudent princes have little hope for reliably engaging in effective political action. The

\footnotetext{
${ }^{125}$ Machiavelli, The Prince, ch. 25, 101.

${ }^{126}$ Najemy, Between Friends, 206.

${ }^{127}$ Machiavelli, The Prince, ch. 25, 101.

${ }^{128}$ Najemy, Between Friends, 206.

${ }^{129}$ Najemy, Between Friends, 207.
} 
"great variability of things...beyond human conjecture" 130 in Machiavelli's own times calls, then, not for a prudent prince but for a prophet. Such a man seeks not to understand the apparent contingency of the political world, but to discern in it signs of prophetic importance. What appears to be a crisis arising from the pure variability of Fortune becomes the sign that the occasione has arrived for an apocalyptic rebirth. What appears to be contingency gains meaning and purpose through its location in an apocalyptic narrative that offers the hope of a final escape from Fortune's variability. Machiavelli's apocalyptic solution does not offer the promise that Fortune's variability becomes intelligible, but rather that it is given a meaning and a conclusion in a way that transcends human understanding at the same time as it transforms humanity.

\section{Fear and Longing: An Ambivalent Rejection of the Apocalyptic Imaginary}

The apocalyptic solution for which Machiavelli pleaded at the end of The Prince was one which offered to give suffering a meaning and an end, to transform humanity, and transcend the political condition. However, in his later works and particularly in The Discourses, Machiavelli denies that these goals are possible or desirable. He turns away from his earlier flirtation with the apocalyptic imaginary by embracing a tragic vision of the political world. This tragic vision entails a reassertion of human frailty in the face of a powerful Fortune and a warning about the dangers of political overreaching. Yet, unlike the apocalyptic imaginary, it does not invite a retreat from the political world, but rather a continued engagement with it even in the face of its inevitable decline.

\footnotetext{
${ }^{130}$ Machiavelli, The Prince, ch. 25, p. 98.
} 
Machiavelli is not conventionally seen as a tragic writer. ${ }^{131}$ Yet, in a 1525 letter to Francesco Guicciardini, Machiavelli signs as "Niccolò Machiavelli, historico, comico et tragico." 132 The first two parts of this identification are hardly controversial. In his guise as an historian, Machiavelli wrote several historical works, most notably The Florentine Histories, and his political pieces are suffused with a concern for history. As a comedian, Machiavelli offered the world Mandragola and Clizia, as well as the numerous amusing letters he addressed to his close friends. It is Machiavelli's self-identification as a tragedian that seems unusual, given that he wrote no works that could be seen as tragedies in the conventional sense of the term. ${ }^{133}$ Yet, Machiavelli's life was marked by political upheaval and crisis, conditions he often laments. Just before closing his letter to Guicciardini, Machiavelli writes: "I vent my feelings by accusing the princes who have all done everything they can bring us to this situation." 134 For Roberto Ridolfi, one of Machiavelli's most passionate biographers, Machiavelli is a tragedian who takes contemporary Italy as his subject. ${ }^{135}$ Yet it is not just in his considerations of the present that Machiavelli embraces the tragic. Machiavelli's later political writings, and particularly the Discourses on Livy, are suffused with the "techniques, scenes, and imagery of tragedy—tyrants, reversals of fortune, stunning acts of cruelty, prophetic dreams and visions, bitter laments." ${ }^{136}$ I intend to take seriously the tragic dimension of Machiavelli's work and to consider how this embrace of tragedy allows him to resist the allure of the apocalyptic imaginary.

\footnotetext{
${ }^{131}$ For notable and interesting exceptions, see: Vickie B. Sullivan, "Introduction," in The Comedy and Tragedy of Machiavelli: Essays on the Literary Works, ed. Vickie B. Sullivan (New Haven: Yale University Press, 2000), ixxxi; Ronald L. Martinez, "Tragic Machiavelli," in Comedy and Tragedy of Machiavelli, 102-119; J. Peter Euben, "The Politics of Nostalgia and Theories of Loss," in Vocations of Political Theory, eds. Jason A. Frank and John Tambornino (Minneapolis: University of Minnesota Press, 2000), 73-83; Giorgio Bárberi-Squarotti, La forma tragica del 'Principe' e altri saggi sul Machiavelli (Florence: Olschki, 1966).

${ }_{132}$ Machiavelli et al., Letter to Francesco Guicciardini (after October 21, 1525), in Machiavelli and his Friends, 371.

${ }^{133}$ This point has previously been made by Sullivan, "Introduction," xi.

${ }^{134}$ Machiavelli, Machiavelli and His Friends, 371.

${ }^{135}$ Roberto Ridolfi, The Life of Niccolò Machiavelli, trans. Cecil Grayson (Chicago: University of Chicago Press, 1963), 219.

${ }^{136}$ Martinez, "Tragic Machiavelli," 110.
} 
The tragic form is one that acknowledges the unaccountable variability of political life. It recognizes that efforts to provide stability and order are always and necessarily temporary. ${ }^{137}$ While Machiavelli's project in The Prince had been to render the political world understandable by containing it with categories and general rules, the opening chapters of The Discourses signal a radically different epistemological approach. The Prince had attempted to group political regimes into stable categories-principalities or republics, new principalities or inherited ones, etc. In The Discourses, Machiavelli denies the stability attempted by this earlier approach. There are three types of 'good' regime-principality, aristocracy, and republic. Yet these regimes are inherently unstable and liable to shift into a corresponding 'bad' regime. Each of these regimes is "so similar to the one next to it that they easily leap from one to the other. For the principality easily becomes tyrannical; the aristocrats with ease become a state of the few; the popular without difficulty converted into the licentious." 138 The best political forms are necessarily temporary, "for no remedy can be applied there to prevent it from slipping into its contrary because of the likeness that the virtue and the vice have in this case." 139 Here, Machiavelli demonstrates a disposition toward the flux and variability of the political world —of the potential for forms to slip into their opposites - that is distinctly tragic. Indeed, a central feature of the tragic form is an attention to the way in which virtue, when taken to excess, becomes vice. ${ }^{140}$ This is an approach that remains open to the variability of politics yet still seeks to understand it. However, it is also an approach which, through its very openness, resists attempts to resolve or put an end to the flux that inheres in politics.

\footnotetext{
${ }^{137}$ Richard Ned Lebow, The Tragic Vision of Politics: Ethics, Interests and Orders (Cambridge: Cambridge: Cambridge University Press, 2003), 378.

${ }^{138}$ Machiavelli, Discourses, I.2, 11. Mansfield and Tarcov translate this passage as: "similar to the next one to it so that they..."

${ }^{139}$ Machiavelli, Discourses, I.2, 11.

${ }^{140}$ Lebow, 363. Shakespeare also makes this point with a horticultural analogy in Romeo and Juliet. The friar explains: "Virtue itself turns vice, being misapplied, / And vice sometime by action dignified. / Within the infant rind of this fair flower / Poison hath residence and medicine power" (Act 2, Scene 3, Lines 21-24).
} 
Machiavelli famously develops this idea by drawing on a cyclical conception of political time borrowed from Polybius. Political regimes inevitably become corrupted and collapse in an unending cycle. Here, Machiavelli is proposing an alternative political temporality that avoids apocalypticism's linear teleology and persistent hope for a ruptural 'end.' In this cyclical temporality, degeneration, decay and crisis can no longer be seen as extraordinary and prophetic signs of an imminent apocalypse. Rather, they gain meaning and intelligibility from their place within a cycle whose broadest outlines have been rendered familiar, and even predictable.

However, I do not want to make too much of the idea of Polybian cycles or of the proposed solution of a mixed government, as both are applied at best unevenly in The Discourses and are totally absent from Machiavelli's other later works. ${ }^{141}$ What remains, however, is a broadly cyclical conception of political time. As Machiavelli explains in The Florentine Histories,

In their normal variations, countries generally go from order to disorder then from disorder move back to order, because - since Nature does not allow worldly things to remain fixed-when they come to their utmost perfection and have no further possibility for rising, they must go down. Likewise, when they have gone down and through their defects have reached the lowest possible depths, they necessarily rise, since they cannot go lower. ${ }^{142}$

Indeed, the entire project that Machiavelli embraces in The Discourses, as well as some of his other historical works, is premised on the notion of perennial political problems that recur as old patterns continue to repeat. However fragmentary and partial the resources of the past are, they can be deployed in the present precisely because human nature remains the same and because

\footnotetext{
${ }^{141}$ J.G.A. Pocock rightly notes that Machiavelli "played down the Polybian formula for stability and the Venetian myth of its attainment" and instead embraced the dynamic model offered by Rome. See: J.G.A. Pocock, "'The Onely Politician': Machiavelli, Harrington and Felix Raab," Historical Studies: Australia and New Zealand 12, no. 46 (1966), 277. See also: Pocock, Machiavellian Moment, 189-90.

${ }^{142}$ Machiavelli, The History of Florence, in Chief Works and Others vol. 3, 1232.
} 
"all people, everywhere and always, [have] led similar histories." ${ }^{143}$ In such an understanding of political time, crises that seem extraordinary and potentially apocalyptic are rendered ordinary and perennial. This cyclical conception of time is often taken as evidence of Machiavelli's republicanism. But it is also a sign of his mature realism-his belief that the crises and antagonisms of political life will repeat themselves indefinitely and resist any attempts at final settlement.

The constant in Machiavelli's various musings on political time is the inevitability of decline. The world, explains Machiavelli, is eternal. ${ }^{144}$ But earthly things rise, decline, and eventually die in "a tragic drama played out again and again." 145 The familiar reasons for this inevitable decline have been well-rehearsed by scholars of Machiavelli's republicanism. Citizens lose a sense of their founding virtues and republics become increasingly corrupt over time. ${ }^{146}$ The founding institutions become ossified as a kind of entropy sets in and the republic's political energies become unfocused. ${ }^{147}$ Yet Machiavelli raises a third reason for the inevitability of political decline. While founders should be considered among the most praiseworthy and honorable of men, they tend to become dangerously emboldened by their past success. After having achieved a successful founding, they become "deceived by a false good and a false glory" and "almost all let themselves go, either voluntarily or ignorantly, into the ranks of those who deserve more blame than praise; and though, to their perpetual honor, they are able to make a republic or a kingdom, they turn to tyranny." ${ }^{148}$ Past success, suggests Machiavelli, heightens the potential for future failure and political decline. Here, the cycles of political time are not

\footnotetext{
${ }^{143}$ Edmund E. Jacobitti, "The Classical Heritage in Machiavelli's Histories: Symbol and Poetry as Historical Literature," in The Comedy and Tragedy of Machiavelli, 178. On the fragmentary nature of the past, see: Discourses, I, preface; Discourses II.5.

${ }^{144}$ Machiavelli, Discourses, II.5, 138-9.

145 Jacobitti, "Classical Heritage," 187.

${ }^{146}$ Machiavelli, Discourses, III.1, 209.

${ }^{147}$ Euben, "Politics of Nostalgia," 82.

${ }^{148}$ Machiavelli, Discourses, I.10, 31.
} 
extrinsic and impersonal forces. Rather, they are patterns in which we ourselves are inescapably implicated. Once again, Machiavelli is invoking a tragic sensibility that emphasizes persistent human frailties and points to the dangers of attempting to exceed our limits.

With this tragic sense of the limits to political action Machiavelli reconsiders the figure of the redemptive prince. He considers a situation that is structurally similar to the one he describes at the end of The Prince - a polity that is utterly degraded and devastated. In the language of republicanism, this is a polity whose corruption has become profound, putting it outside the familiar cycles of growth and decline he describes elsewhere in The Discourses. He suggests that the transformation and apocalyptic rebirth that he had hoped and pleaded for at the end of The Prince are simply impossible. He reasons: "where [the matter] is corrupt, well-ordered laws do not help unless indeed they have been put in motion by one individual who with an extreme force ensures their observance so that the matter becomes good. I do not know whether this has ever occurred or whether it is possible." ${ }^{149}$ In light of the final chapter of The Prince, this is a remarkable admission. The redemptive figure Machiavelli had hoped for in that work was extraordinary and unprecedented — a figure that exists outside of history and is able to effect a transformation that has never occurred before and is not ordinarily possible. The transformative re-founder discussed in The Discourses seems similar. He is a charismatic leader who promises to renovate a devastated polity, transform its complacent masses, and innovate new orders "at a stroke." ${ }^{150}$ However, the figure in The Prince is able to perform a miracle that redeems his people's suffering, transforms them, and ushers in a new age. Here in The Discourses, Machiavelli denies the possibly of such a miracle, revealing the promise of a transformative refounder to be both fraudulent and dangerous.

\footnotetext{
${ }^{149}$ Machiavelli, Discourses, I.17, 48.

${ }^{150}$ Machiavelli, Discourses, I.18, 51.
} 
In the mode of rational deliberation rather than apocalyptic hope, Machiavelli considers the possibilities available to a corrupt polity. The only way in which a political rebirth is possible is "through the virtù of one man who is alive [at the time]...As soon as such a one is dead, [the polity] returns to its early habit." ${ }^{, 151}$ Here, the re-founder is merely human and therefore subject to mortality. The rebirth he initiates allows new orders to be sustained, but only as long as he lives to guarantee them. Unable to effect a transformation of the people themselves, the re-founder cannot protect his new polity from decay. While the millennial community hoped for at the end of The Prince was unable to be undermined because absolute power was guaranteed by absolute love, the reborn republic is destined for an eventual decay from which there is no apocalyptic exit.

Shifting from the mode of rational deliberation to normative critique, Machiavelli argues that even if a redemptive and prophetic leader were possible, he would not be the kind of person for whom we should hope longingly. Even if a single re-founder could live an exceptionally long life or could arrange to be succeeded by one who shares his predecessor's virtù and political mission, the polity could only "be reborn with many dangers and much blood." 152 This is a clear allusion to the violence that would be required to effect the kind of transformation longed for at the end of The Prince. In this earlier work, the transformation takes the form of a miracle of spontaneous transformation and submission to the absolute power of a redemptive prophet. Here, however, Machiavelli exposes the bloody work of any transformative endeavor aimed at total and eternal human transformation. Here, the price of an attempted transformation has become too high. Lurking behind Machiavelli's remarks in The Discourses is also a deeper fear that, instead of waiting for an occasione of devastation and suffering, a self-proclaimed redeemer

\footnotetext{
${ }^{151}$ Machiavelli, Discourses, I.17, 48.

${ }^{152}$ Machiavelli, The Discourses, I.17, 48.
} 
might attempt to create this occasione for himself through the use of profound and unimaginable violence. While the redemptive figure in The Prince is not an agent of violence, having come across an already devastated people, the transformative refounder of The Discourses unleashes a violence that may ultimately be irredeemable. Consistent with a tragic mood, Machiavelli confronts us with the limits of political action and the profound dangers we create by trying to exceed them.

Yet Machiavelli's message is certainly not one of retreat from the political world. Rather, the struggle with Fortune and with human limits is the stuff of politics. Machiavelli summarizes this connection between the tragedy of politics and engagement with the world in verse:

That which more than anything else throws kingdoms down from the highest hills is this: that the powerful with their power are never sated.

From this results that they are discontented who have lost, and hatred is stirred up to ruin the conquerors;

whence it comes about that one rises and the other dies; and the one who has risen is ever tortured with new ambition and with fear.

This appetite destroys our states; and the greater wonder is that all recognize this transgression, but no one flees from it. ${ }^{153}$

Seen in this light, the heroes of The Discourses are those who found and refound polities knowing that they will eventually decay. All earthly creations, suggests Machiavelli, have limits to their lives. ${ }^{154}$ Yet, since fortune "proceeds by oblique and unknown ways," it makes little sense to withdraw from the world of politics. While the lives of states and men have limits, the aim should be "to live in a manner that would allow one to live out that limit."155 Machiavelli, in his guise as a tragedian, does not leave us despairing or encourage us to turn away from the world. Rather, like the Florentine thinker himself, who must write about politics or remain

\footnotetext{
${ }^{153}$ Niccolò Machiavelli, The [Golden] Ass, in Allan Gilbert (ed.) Chief Works and Others, vol. 2 (Durham: Duke University Press, 1989), ch. 5.37-46, 762.

${ }^{154}$ Machiavelli, Discourses, III.1, 209.

155 Jacobitti, "Classical Heritage," 180.
} 
silent, ${ }^{156}$ we must engage with the political world even in the face of the limits imposed both by ourselves and by Fortune.

The political world that Machiavelli describes and celebrates in The Discourses and other later works is a turbulent one that resists any attempts to impose an eternal stasis. In the early chapters of The Discourses, Machiavelli makes "a series of decisions against studying the closed, aristocratic, defensive state —Sparta or Venice — which makes stability its only goal, and in favour of studying the dynamic, popular, warlike state — Livian Rome — which opts for liberty, expansion and dominion, even if this choice condemns it to ultimate decline and tyranny.",157 The entire project of The Discourses embraces a model of politics in flux - the constant motion produced by repeated engagements with Fortune and confrontations with other political actors. Against an ideal of an eternal stillness, Machiavelli celebrates a Roman ideal of antagonism and struggle. The "tumults between the nobles and the plebs," for instance, "were the first cause of keeping Rome free."158 It is also an ideal that is explicitly anti-apocalyptic insofar as it eschews the promise of order, unity and quiet offered by a final exit from the tumult and antagonism of the political condition.

Yet Machiavelli's embrace of a fluid politics is haunted by the lingering persistence of the apocalyptic imaginary. I suggest that this persistence manifests itself in the desire to put an end to the flux and struggle of politics by establishing an everlasting republic. Like the apocalyptic and redemptive 'end' envisioned at the end of The Prince, the everlasting republic would mark the eternal culmination of the movement that characterizes the political world. For the most part, Machiavelli eschews a redemptive and apocalyptic end to politics in The Discourses. He argues that there are no certain remedies for political disorders and that "it

\footnotetext{
${ }^{156}$ Machiavelli, Letter to Francesco Vettori (April 9, 1513), in Machiavelli and His Friends, 225.

${ }^{157}$ Pocock, “Onely Politician,” 277. See also: Machiavelli, Discourses, I.1, 2, 5, 6.

${ }^{158}$ Machiavelli, Discourses, I.4, 16.
} 
follows that it is impossible to order a perpetual republic, because its ruin is caused through a thousand unexpected ways." 159 This is consistent with Machiavelli's insistence on the inevitable decline of states and the constant flux and struggle that inheres in the political condition. Yet he simply cannot fully abandon the hope of a ruptural and extraordinary figure who "with his example might renew the laws, and not only restrain [the republic] from running to ruin but pull it back [such that] it would be perpetual." ${ }^{.160}$ Like the Savonarolan apocalyptic imaginary, the hope for an everlasting republic envisions an end that is achieved through a backward movement in time to a simpler and uncorrupted period that can be held in stasis eternally. This halting of the motion of Fortune would, if possible, be "the true political way of life and the true quiet of a city." 161 Given Machiavelli's openness to a politics in motion, animated by struggle and discord, the hope for a perpetual republic characterized above all by 'quiet' is troubling. It resonates eerily and closely with St. Augustine's famous description of the eschatological City of God as a place in which "we shall have the leisure to be still."162 This haunting eschatological hope reveals a lingering ambivalence in Machiavelli's rejection of apocalypse and perhaps an implicit admission that even the tragedian and the realist cannot fully extinguish the desire to escape from politics.

\section{Conclusion}

In this chapter, I have offered a reading of Machiavelli that challenges some of the dominant interpretations of the Florentine thinker in the history of political thought, particularly

\footnotetext{
${ }^{159}$ Machiavelli, Discourses, III.17, 257.

${ }^{160}$ Machiavelli, Discourses, III.22, 266.

${ }^{161}$ Machiavelli, Discourses, I.6, 23.

${ }^{162}$ As quoted in: Paul R. Wright, "Machiavelli's City of God: Civic Humanism and Augustinian Terror," in Augustine and Politics, eds. John Doody, Kevin L. Hughes, and Kim Paffenroth (Lanham: Lexington Books, 2005), 325. I am indebted to Wright's interesting chapter for first prompting me to think about the eschatological dimensions of Machiavelli's hope for a perpetual republic.
} 
those that treat him as a modern political realist. However, my aim here has not been to contest Machiavelli's identification as a realist, but rather to offer a more complex and nuanced account of the development of his realism in response to the apocalyptic imaginary. This account has several implications for Machiavelli's identification as a realist. First, many are inclined to treat The Prince as the primary locus of Machiavelli's realism and to see The Discourses as an exclusively republican work. However, I have offered a reading of The Prince that emphasizes the utopian and apocalyptic character of the concluding chapter of the work. The Prince must culminate in an apocalyptic exhortation because the rest of the work has failed to achieve the goal of a narrow and underdeveloped political realism - to subject the variability of politics to princely control by containing it with categories and general rules. I find a much more developed and complex realism in Machiavelli's later works, and especially The Discourses, which are infused with a tragic sensibility that emphasizes the real limits to political action and the dangers we create by trying to exceed them. Importantly, while this may be a tragic realism, it is not one that prescribes withdrawal from the world, but rather continued engagement with it. Second, the reading that I have offered here suggests that Machiavelli's realism is deeply contextual. It only fully develops through an attempt to reject the apocalyptic imaginary. Importantly, however, this is not simply an engagement between Machiavelli ('the realist') and Savonarola and his followers ('the apocalypticists'). It is also a struggle that is internal to Machiavelli's own work. The complex and tragic realism that Machiavelli eventually embraces emerges only after an engagement with the apocalyptic imaginary.

Third, the interpretation I have offered here complicates attempts to cast Machiavelli as a modern realist — a thinker whose commitment to exploring the effectual truths of power politics marks his work as a definitive break from the political thought of medieval Christianity. 
Machiavelli's engagement with political theology in general, and the apocalyptic imaginary in particular, necessarily complicates any attempt to place him firmly on either side of a premodern/modern divide. Finally, and perhaps most importantly, I have pointed to lingering questions about the adequacy of tragic realism as a response to the apocalyptic imaginary. While Machiavelli's turn toward a robustly tragic sensibility in his later work represents an attempt to turn away from the apocalyptic imaginary and its fantasies of a final solution to the contingency of political life, this rejection is incomplete. The Discourses are haunted by an eschatological hope for a perpetual republic. The apocalyptic imaginary is not easily purged. As I explore in the following chapter, Thomas Hobbes will opt not for a strategy of purging the apocalyptic imaginary but rather of subversively integrating it into the very foundations of his political thought. 


\section{CHAPTER FOUR}

\section{THOMAS HOBBES: "FEIGNING THE WORLD TO BE ANNIHILATED"}

Recalling the circumstances of his birth, Thomas Hobbes wrote that his mother "brought twins to birth, myself and fear at the same time." His premature birth on April 5, 1588 was caused, Hobbes claimed, by rumors of an approaching Spanish Armada that "was bringing the day of doom to our race." These rumors had been circulating for several months and the English awaited the Spanish fleet with a sense of utter dread. But there were other reasons to expect "the day of doom." The year 1588 had been the focus of apocalyptic expectation and terror for over a century. One prominent fifteenth-century prediction expected that the year would bring "with it woe enough. If this year, total catastrophe does not befall, if land and sea do not collapse in total ruin, yet will the whole world suffer upheavals, empires will dwindle and from everywhere will be great lamentation." ${ }^{2}$ During the course of Hobbes' life, there would be an explosion of apocalyptic prophecy that combined fears of the imminent end of the known world with hopes for a radically new future. The chaos and violence of the English Civil War only seemed to confirm these prophetic revelations and there emerged a widespread expectation that God would irrupt into secular history to save the elect and condemn the damned.

In this chapter, I argue that this apocalyptic imaginary shaped Hobbes' later work, and particularly Leviathan. Yet, while a substantial amount of scholarship has grappled with the English thinker's understanding of the political implications of religion and his accounts of the origins of the civil war, Hobbes' engagement with apocalypticism remains profoundly

\footnotetext{
${ }^{1}$ As quoted in Arnold A. Rogow, Radical in the Service of Reaction (New York: W.W. Norton, 1986), 17.

${ }^{2}$ Garrett Mattingly, The Armada (Boston: Mariner/Houghton Mifflin, 2005), 176. There were numerous similar prophecies circulating at the time of the Armada. See: Mattingly, The Armada, 172-86. Francis Bacon mentions the quoted prophecy, along with others concerning 1588, in his brief essay "On Prophecies." See: Francis Bacon, Bacon's Essays, ed. F.G. Selby (London: MacMillan and Co., 1889), 95-6.
} 
underexplored. ${ }^{3}$ I argue here that the radical apocalyptic imaginary let loose during the civil war is a central preoccupation of Hobbes' work. While Christian eschatology had initially been deployed as a legitimating tool by kings and church authorities, the apocalyptic imaginary escaped this effort at sovereign control and was suddenly abroad in the land. Hobbes responds to this threat not by condemning the apocalyptic imaginary, but by trying to put it back in the service of sovereign power. He fights apocalypse with apocalypse. Hobbes pursues two paths in his project—one that is overtly Christian and another that is seemingly secular. His theological argument offers a de-radicalized Christian eschatology in which the sovereign is the only authority capable of proclaiming the apocalypse. Hobbes' political argument stages a secular apocalypse, in which the terror and chaos of the state of nature are the preconditions for a kingdom ruled by a mortal God. In pursuing these two paths, Hobbes does not escape the apocalyptic imaginary, but rather redeploys it and tries to return it safely into sovereign hands.

This chapter proceeds in three parts. First, I begin by tracing the evolution of the apocalyptic imaginary from the late sixteenth century to the English Civil War, with a particular focus on its relationship to sovereign power. Second, I outline Hobbes' theological response to the apocalyptic imaginary. Here I raise questions about the value of a response to Christian eschatology that does not engage with the capacity of apocalypticism to captivate the imagination and provoke belief. Third, I argue that Hobbes' seemingly secular response to the anarchic potential of apocalypticism is more successful because it works on an imaginistic register, offering a vivid and frightening picture of an alternative eschaton.

\footnotetext{
${ }^{3}$ For three notable exceptions, see: J.G.A Pocock, "Time, History and Eschatology in the Thought of Thomas Hobbes," in The Diversity of History: Essays in honour of Sir Herbert Butterfield, eds. J.H. Elliott and H.G. Koenigsberger (Ithaca: Cornell University Press, 1970), 149-98; A.P. Martinich, The Two Gods of Leviathan: Thomas Hobbes on Religion and Politics (Cambridge: Cambridge University Press, 1992), esp. 247-68; Kinch Hoekstra, "Disarming the Prophets: Thomas Hobbes and Predictive Power," Rivista di storia della filosofia 21, no. 1 (2004): esp. 100-109.
} 


\section{The English Apocalyptic Imaginary}

The apocalyptic imaginary that captivated England from the Reformation through the civil war drew on a rich theological tradition. Other scholars have captured this richness in fuller detail than I am able to provide here. ${ }^{4}$ I focus on three of the most important and influential theological sources for the apocalyptic imaginary that would come to dominate Hobbes' world: John Bale's Image of Both Churches (1547) ${ }^{5}$, John Foxe's Acts and Monuments $(1563)^{6}$, and the Geneva translation of the Bible $(1560,1599) .^{7}$ The choice of these three works is far from arbitrary. Historians studying sixteenth and seventeenth century English apocalypticism tend to agree that Bale, Foxe, and the translators and annotators of the Geneva Bible developed an interpretive tradition that would provide the basis for the radical apocalyptic polemics of the seventeenth century. ${ }^{8}$ In addition, these writers came into frequent contact with one another and with theologians and religious dissidents on the Continent, building upon and integrating one another's ideas into a self-consciously new Protestant apocalyptic tradition. ${ }^{9}$ Together, these works articulated a uniquely Protestant reading of the apocalypse that would take on a life of its own in the violence and hopes of the English Civil War.

\footnotetext{
${ }^{4}$ For more detailed accounts, see: Paul Christianson, Reformers and Babylon: English Apocalyptic Visions From the Reformation to the Eve of the Civil War (Toronto: University of Toronto Press, 1978), 13-92; Katharine R. Firth, The Apocalyptic Tradition in Reformation Britain (Oxford: Oxford University Press, 1979); Bernard Capp, “The Political Dimension of Apocalyptic Thought," in The Apocalypse in English Renaissance Thought and Literature: Patterns, Antecedents and Repercussions, eds. C.A. Patrides and Joseph Wittreich (Ithaca: Cornell University Press, 1984), 93-124; Crawford Gribben, The Puritan Millennium: Literature and Theology 1550-1682 (Dublin: Four Courts Press, 2000a), 26-79.

${ }^{5}$ Bale published the work in three parts. The first appeared in 1541, the second in 1545, and the third in 1547.

${ }^{6}$ Foxe published the first edition of Acts and Monuments, in Latin, in Basel in 1559. The first English edition, which contained substantial expansions from the Latin version, was published in 1563. Foxe published three subsequent English editions in his lifetime, with varying degrees of revision.

${ }^{7}$ There were several versions of the Geneva translation. The first full version appeared in 1560, but was not published in England until 1575/6. In 1599, a new version appeared with Franciscus Junius' newly translated notes on Revelation. In this chapter, I draw on both the 1560 and 1599 editions.

${ }^{8}$ See: Christianson, Reformers and Babylon, 13-46; Gribben, Puritan Millennium, 26-79; Firth, Apocalyptic Tradition, 32-149.

${ }^{9}$ Large parts of Bale's "apocalyptic framework" were absorbed into Foxe's Acts and Monuments and the annotations in the Geneva Bible. See: Christianson, Reformers and Babylon, 36.
} 
Appropriately enough, these apocalyptic writers all wrote in exile. John Bale fled to Flanders when his powerful protector, Thomas Cromwell, fell out of favor with King Henry VIII in 1540. He returned briefly with the accession of King Edward VI, but like John Foxe and the translators and annotators of the Geneva Bible he was forced into exile once again with the accession of the violently pro-Catholic Queen Mary in 1553. Like other Marian exiles, Bale, Foxe, and those who worked on the Geneva translation, fled to Protestant cities on the Continent. By virtue of their exile, they were engaged in an ancient apocalyptic tradition. As Crawford Gribben explains, "apocalyptic interest always seemed to thrive when the godly were both persecuted and geographically estranged. The place of exile, like the Biblical wilderness, was a topography loaded with spiritual significance. Daniel had received his eschatological prophecy while in Babylonian exile, and John had documented Revelation while in banishment." ${ }^{, 10}$ Irish bishop John Bale makes this connection explicit in the preface to his work, The Image of Both Churches. He notes that Revelation was written in exile, and then continues: "In exile are the powers thereof most earnestly proved of them that have faith...[F]or nought is it not therefore, that [God] hath exiled a certain number of believing brethren of the realms of England; of which afflicted family my faith is that I am one."11 Together, these exiles would help forge an English apocalyptic tradition informed by their persecution at home and their connections to a vibrant Protestant community on the Continent. ${ }^{12}$

While the writings of the Marian exiles would soon shape increasingly radical Puritan movements in England, the intentions of their authors were far from revolutionary. The

\footnotetext{
${ }^{10}$ Gribben, Puritan Millennium, 57.

11 John Bale, as quoted in Christianson, Reformers and Babylon, 14.

${ }^{12}$ Katharine R. Firth argues: "For the development of the apocalyptic tradition in Britain no six years were more important than those from 1553 to 1559 . The period of the Marian exile, during which some eight hundred persons gathered in a few Protestant cities on the continent, was marked by close association and co-operation between the exiles and scholars from all over the Protestant world." See: Firth, The Apocalyptic Tradition, 69.
} 
European Protestants with whom the Marian exiles associated were deeply wary of the destabilizing potential of apocalyptic hopes. Twenty years earlier, the German town of Münster had been the site of an Anabaptist apocalyptic revolt, in which radicals proclaimed the town to be the New Jerusalem and attempted to create a proto-socialist theocracy. Besieged by Catholic forces and cut off from the outside world, the town succumbed to famine and cannibalism. Those who survived eventually surrendered in exchange for the offer of safe conduct, but were instead brutally massacred and their corpses exhibited in cages as a lesson to others attracted to the antinomian messages of Revelation. ${ }^{13}$ To the Continental Protestants of the $1550 \mathrm{~s}$ and the Marian exiles who dwelt among them, Münster served as a powerful reminder of the destabilizing potential of the apocalyptic imaginary and the dangers of a "totally unlegislated reading" of Scripture. ${ }^{14}$ Protestant theology would now have to direct itself with equal vigor toward "the twin threats of the totalitarianism of Rome and the danger of sectarian frenzy."15 The work of the Marian exiles is centrally concerned with these twin threats.

John Bale's Image of Both Churches offers a sophisticated theological response that attempts to both condemn the Catholic Church and to close off the destabilizing potential of the apocalypse. Written before the period of the Marian exile, Bale's apocalyptic understanding of history had a profound influence on Foxe's Acts and Monuments and the translations and annotations in the Geneva Bible. Borrowing from Augustine's conception of two cities, Bale reads Revelation as a prophecy of the unfolding of Christianity. To Bale, the final book of the Bible describes the parallel development and opposition of two churches - the "true Christian church...the meek spouse of the Lamb without spot...and the sinful synagogue of Satan."16

\footnotetext{
${ }^{13}$ Gribben, Puritan Millennium, 34-5.

${ }^{14}$ Gribben, Puritan Millennium, 67.

${ }^{15}$ Gribben, Puritan Millennium, 35.

${ }^{16}$ John Bale, as quoted in Gribben, Puritan Millennium, 37.
} 
Bale's reading identifies his Protestant contemporaries with the persecuted elect of the "true" church. In so doing, he gives Protestants a past that stretches back to the early church. The Church establishment in Rome is the false church, and therefore among the forces of Antichrist. As Paul Christianson explains, "By applying the idea of the two churches, Bale stood history on its head. The church establishment of the middle ages, headed by the papacy, became the vassals of antichrist, while many hounded as heretics in the same period became the small, pure, persecuted elect of the true church."17

Yet, while Bale's historical reading of Revelation provided theological fodder for the contemporary struggles between Protestants and Rome, he does not offer a call to apocalyptic action. As we shall see, many of his Protestant contemporaries pinned their hopes for apocalyptic transformation on an established political authority — a godly prince able to carry out the events prophesied in Revelation by ending the persecution of the elect and doing battle with the forces of Antichrist. For Bale, however, kings and princes are incapable of such divine tasks. God has not given kings the power "to subdue these beasts. Only is it reserved to the victory of his living word." 18 The agents of God are the persecuted, the oppressed, and those who preach the divine message. Yet Bale is careful to avoid the kinds of destabilizing doctrines that might fuel politically radical ambitions. Following Augustine, he offers no immediate hope for a glorious millennium and is cautious and vague when addressing possible futures prophesied in Revelation. ${ }^{19}$ His commentary on the portions of Revelation describing the New Jerusalem simply paraphrases the Biblical text and avoids drawing almost any connection to the plight of

\footnotetext{
${ }^{17}$ Christianson, Reformers and Babylon, 15.

18 John Bale, as quoted in Christianson, Reformers and Babylon, 19.

${ }^{19}$ Gribben, Puritan Millennium, 37-8; Firth, Apocalyptic Tradition, 56.
} 
Protestant reformers. ${ }^{20}$ Ultimately, his work provided Protestants with an eschatological history, but did not urge them toward a prophetic future.

Like Bale, Foxe focuses his reading of Revelation on the past and present. Acts and Monuments, also known as The Book of Martyrs, blends an eschatological reading of history with an older genre describing the lives of saints. Deploying Bale's notion of two churches, Foxe catalogues and details the persecution of the elect in an historical eschatology that links the Marian exiles back to the apostles in an unbroken trail of blood. ${ }^{21}$ The elect are identified by their suffering and the forces of Antichrist are marked by their eagerness to persecute. ${ }^{22}$ Yet, while their persecution and martyrdom give members of the true church a place in the apocalyptic drama, Foxe does not encourage any direct action on their part. Political agitation and subversion are vices practiced by papal supporters: "What kings have been deposed, and emperors stripped from their imperial seat, and all because they would not stoop and bend to the image of the beast, that is, to the majesty and title of Rome."23 To the extent that the elect have an active role to play in the apocalypse, it is through their leaders. In the 1563 edition of Acts and Monuments, Foxe casts Queen Elizabeth as a new Constantine, a godly ruler who ends the persecution of the elect and "confound[s] the dark and false-valorized kingdom of Antichrist."24 The work's dedication to Elizabeth makes this connection clear. In the opening lines of the dedication, the $\mathrm{C}$ in 'Constantine' is illustrated with a picture of the Queen triumphing over the body of the Pope (see figure 5). Just as Constantine ended the persecution of the early church, Elizabeth will stop the suffering of Protestants. The dedication in the 1570 edition of the book

\footnotetext{
${ }^{20}$ Christianson, Reformers and Babylon, 18.

${ }^{21}$ Gribben, Puritan Millennium, 59; Richard Helgerson, Forms of Nationhood: The Elizabethan Writing of England (Chicago: University of Chicago Press, 1992), 256.

${ }^{22}$ Helgerson, Forms of Nationhood, 259.

${ }^{23}$ John Foxe, as quoted in Capp, "The Political Dimension," 94.

${ }^{24}$ John Foxe, as quoted in Christopher Hill, Antichrist in Seventeenth-Century England (London: Verso, 1971$), 14$.
} 


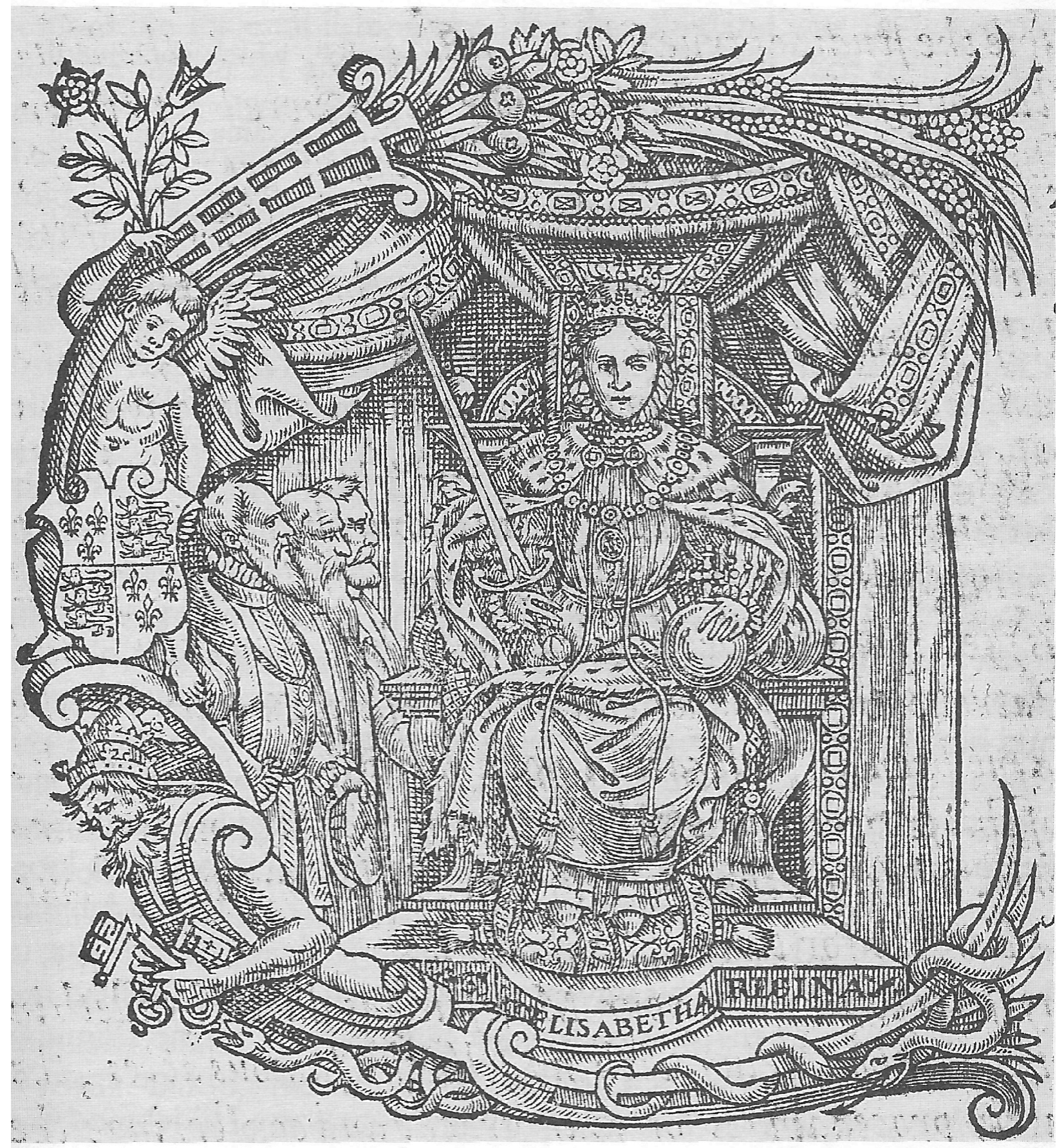

Figure 5: Illustration in the ' $\mathrm{C}$ ' from the dedication of the 1563 edition of John Foxe's Acts and Monuments, 1653. Henry E. Huntington Library, San Marino. 
discusses Christ, rather than Constantine. But the $\mathrm{C}$ in 'Christ' bears the same image of Elizabeth. $^{25}$ Foxe thus builds on Bale's framework to develop a Protestant eschatological identity grounded in history and prophecy, while only offering the elect an active role in the apocalypse through the actions of their godly sovereign.

The Geneva Bible further develops Bale's Protestant apocalyptic theology. This clear and forceful translation was one of the most enduring achievements of the Marian exiles. Rich with detailed annotations, cross-references, indices, woodcut illustrations, and maps of the holy land, it was a mass-produced translation that provided its English readers with the world's first study bible. It gained official status in Scotland, where a 1579 Act of Parliament required that "every substantial householder [be] required to purchase a copy." "26 Even without official recognition, "the Geneva Bible became the Bible of Elizabethan England." 27 It was Shakespeare's bible and that of many of other Elizabethan and Jacobean authors. ${ }^{28}$ It was also one of the bibles taken to America on the Mayflower and the translation became wildly popular in the colonies. ${ }^{29}$ And when Oliver Cromwell's Parliamentarian troops marched into battle, they did so with a Soldiers Pocket Bible comprised of verses taken from the Geneva translation. ${ }^{30}$

Influenced by the ideas of Bale and Foxe, the Geneva Bible has an overt anti-Catholic and apocalyptic agenda. While Antichrist plays a small role in the bible and is mentioned in only three passages ${ }^{31}$, the translators of the Geneva version chose to capitalize "Antichrist." This decision was not maintained in the Authorized (King James) Version, a fact that hints at the

\footnotetext{
${ }^{25}$ Frances Amelia Yates, Astraea: The Imperial Theme in the Sixteenth Century (Harmondsworth: Penguin, 1977), 42.

${ }^{26}$ Maurice S. Betteridge, "The Bitter Notes: The Geneva Bible and Its Annotations," The Sixteenth Century Journal 14, no.1 (1983): 44.

${ }^{27}$ Betteridge, "The Bitter Notes," 44.

${ }^{28}$ David Daniell, The Bible in English: Its History and Influence (New Haven: Yale University Press, 2003), 295.

${ }^{29}$ Betteridge, "The Bitter Notes," 53.

${ }^{30}$ Daniell, The Bible in English, 295.

${ }^{31} 1$ John 2:18, 22; 1 John 4:3; and 2 John 7.
} 
Geneva translation's "more polemical apocalyptic agenda." ${ }^{32}$ The annotations further support this assessment. "Antichrist" is identified with "the man of sin" and the "son of perdition" of 2 Thessalonians 2:3. This antichristian adversary is then identified with the papacy and the Pope with the second beast in Revelation 13. The second beast inherits the powers of the first, which the notes identify as the Roman Empire. The Pope "is the head both of the tyrannical Empire, and also of the false prophets." He "exercises a most wicked and most insolent tyranny over the persons of men...and over their goods and actions. ${ }^{, 33}$ The papacy was part of a chain of antichristian forces, for Antichrist "comprehendeth the whole succession of the persecutors of the church." He "shall not reign without the Church, but in the very bosom of the Church.",34 Yet, like Bale and Foxe, the Geneva Bible attempts to avoid encouraging the kind of Protestant enthusiasm that had been so disastrous at Münster. Indeed, the Bible's marginal annotations were meant to "offer the interpretive guidelines required by those protestants concerned to support the social and religious status quo." ${ }^{35}$ The destruction of Antichrist would not occur through the spontaneous action of individual Protestants, but rather would be exercised through existing channels of sovereign power. The distinctly eschatological preface to the 1560 Geneva Bible was addressed to Queen Elizabeth. One of the notes on Revelation explains that "Kings and Princes (contrary to that wicked opinion of the Anabaptists) are partakers of the heavenly glory, if they rule in fear of the Lord. ${ }^{36}$ While the Geneva Bible claims Scriptural authority for the Protestant cause, it does not challenge sovereign power.

\footnotetext{
${ }^{32}$ Gribben, Puritan Millennium, 28.

331599 Geneva Bible, note on Revelation 13: 12-16.

341599 Geneva Bible, note on 2 Thessalonians 2: 3-4.

${ }^{35}$ Gribben, Puritan Millennium, 67. Nevertheless, the Church of England and King James recognized enough antimonarchical exegesis in the Geneva translation to justify commissioning an Authorized Version to replace it. This move did not decrease the popularity of the Geneva Bible, which was still in widespread use during the English Civil War.

${ }^{36} 1560$ Geneva Bible, note on Revelation 21:24. As Crawford Gribben explains, "this confirmation of England's establishment would find fewer echoes in succeeding editions of puritan scriptures." This shift is part of a larger
} 
While Bale, Foxe, and the translators and annotators of the Geneva Bible had attempted to avoid encouraging Protestant enthusiasm, their works would form the theological basis for the Puritan apocalypticism of the English Civil War. This fact confronts historians with a bit of a puzzle. How did the politically moderate Protestant apocalypticism of the sixteenth century become the radical apocalypticism of the seventeenth century? In order to understand how this happened, we must trace three important shifts in English apocalypticism that occurred between the reigns of Queen Elizabeth I (1558-1603) and King Charles I (1625-1649). First, England gained a special role in the apocalyptic drama. For Bale and Foxe, the true church was universal and the elect were spread throughout the world. ${ }^{37}$ Both drew substantial material from English history, reading the experiences of the country's reformers and Protestants alongside Revelation. However, they did not single England out for a special role in any apocalyptic transformation. ${ }^{38}$ This special status developed in the aftermath of England's defeat of the Spanish Armada in 1588 , after which the country was increasingly cast as an elect nation chosen by God to take an active role in the apocalyptic drama. ${ }^{39}$ The failure of the Gunpowder Plot in 1605 was taken as a further sign that England was under divine protection. ${ }^{40}$ This special role for England would be an overtly activist one. As Bernard Capp explains, "English Protestants were no longer merely

transformation in English apocalypticism that I explore in the following pages. See: Crawford Gribben, "Deconstructing the Geneva Bible: The Search for a Puritan Poetic," Literature and Theology 14, no. 1 (2000): 5.

${ }^{37}$ Capp, "The Political Dimension," 96.

${ }^{38}$ William Haller argues that Foxe did identify England as an elect nation. See: William Haller, Foxe's First Book of Martyrs and the Elect Nation (London: Jonathan Cape, 1963). Katharine Firth, among others, has convincingly criticized this thesis. See: Firth, The Apocalyptic Tradition, 107-8. It is worth noting, however, that Foxe's work was added to substantially over time and later editions did incorporate a stronger role for England. Also, as Bernard Capp has explained, it is worth remembering that the focus on English examples in the work of both Foxe and Bale had the effect of appearing to confirm England's importance in the apocalyptic drama. See: Capp, "The Political Dimension," 96.

${ }^{39}$ Capp, "The Political Dimension," 98.

${ }^{40}$ Christianson, Reformers and Babylon, 108. 
preachers spreading the Gospel or martyrs suffering patiently" but an army "which would throw down Babylon."41

At the same time, there was a second shift in the agent of the apocalyptic transformation. For Bale and Foxe, the principal actors in the apocalyptic drama are martyrs - the persecuted and the oppressed who belong to the true church. But they play a passive role. To the extent that early Protestant apocalyptics envision any kind of active agency, it is in the role of a "godly prince" who will fight the forces of Antichrist and end the persecution of the true church. This is the role that Foxe and the translators and annotators of the Geneva Bible assign to Queen Elizabeth I. ${ }^{42}$ When James I succeeded Elizabeth, he became the focus of similar apocalyptic hopes. This is understandable, given that James had written an extensive commentary on Revelation, identifying the pope as Antichrist and prophesying the imminent overthrow of Catholic nations. ${ }^{43}$ James I seemed to have all the right Protestant apocalyptic credentials. Yet the political decisions he made during his reign did little to satisfy radical apocalyptic hopes. He made peace with Spain, he refused to intervene on the Protestant side in the Thirty Years War,

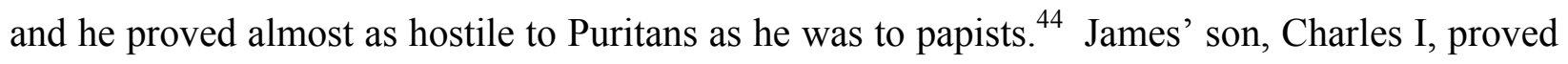
even less satisfactory as a candidate for the "godly prince." He married a Catholic and supported the Arminian ${ }^{45}$ party in the Church, which promoted religious ceremonies widely condemned as "popish." He was also openly hostile to the identification of the papacy with Antichrist. ${ }^{46}$ With their hopes of a "godly prince" dashed, radical Protestants in England began to focus on

\footnotetext{
${ }^{41}$ Capp, "The Political Dimension," 98.

${ }^{42}$ A caveat is in order here. Bernard Capp reminds us that while "most Protestant writers saw Elizabeth as having a major, distinctive or even unique position in the Church's history...they stopped short of ascribing a messianic role to her." See: Capp, "The Political Dimension," 96.

${ }^{43}$ Capp, "The Political Dimension," 102.

${ }^{44}$ Capp, "The Political Dimension," 103.

${ }^{45}$ Arminians differed from Calvinists in their views regarding predestination. Calvinists tended to view Arminians as dangerously similar to Catholics. Under Charles I, many Arminians rose to prominent positions in the Church and the state.

${ }^{46}$ Capp, "The Political Dimension," 104.
} 
Parliament, or even the community of believers at large, as agents of apocalyptic transformation. ${ }^{47}$ The alliance between apocalyptic hope and sovereign power had dissolved.

Finally, and perhaps most importantly, there was a shift in the location of Antichrist. Bale, Foxe, and the translators and annotators of the Geneva Bible had all associated the pope and the institution of the papacy with Antichrist. By Elizabeth's reign, these links had become even more overt. It was entirely respectable to argue that the pope himself was Antichrist. This identification served the interests of sovereign power, unifying England against a common papal enemy - Spain. Before he succeeded Elizabeth, James had written a commentary on Revelation in which he clearly asserted that the pope was Antichrist. ${ }^{48}$ He viewed papal attempts to meddle in the secular jurisdiction of princes as particularly anti-Christian and as a threat to sovereign power. ${ }^{49}$ Yet, during his reign, James seems to have become increasingly aware of the politically destabilizing effects of identifying the pope with Antichrist. It was hard to argue against those who criticized James' peace with Spain and failure to intervene on behalf of Protestants abroad, as these critics were merely seeking action against the Roman Antichrist. ${ }^{50}$ Perhaps for this reason, James backed down from his earlier views. ${ }^{51}$

The more radical implications of this identification emerged under Charles I. The Church of England under Archbishop Laud and the Arminians was widely seen by its Puritan opponents as "popish" and sympathetic to the Catholic Church. Since the pope was Antichrist, argued

\footnotetext{
${ }^{47}$ Capp, "The Political Dimension," 105; Gribben, Puritan Millennium, 45. This shift is on full display in William Prynne's thought. See: Christianson, Reformers and Babylon, 192.

${ }^{48}$ A Fruitful Meditation, Containing a Plaine and Easie Exposition, or laying open of the VII VIII. IX. and X. Verses of the 20. Chapter of the Revelation, in forme and manner of a Sermon (1588).

${ }^{49}$ Hill, The Antichrist, 65.

${ }^{50}$ Hoekstra, "Disarming the Prophets," 101. Capp points out that Elizabeth I came to have similar problems. See: Capp, "The Political Dimension," 99.

${ }^{51}$ Hill, The Antichrist, $34-5$.
} 
some Puritans, so too must be his agents in England. ${ }^{52}$ The "hatred traditionally directed outwards towards the pope or Hapsburgs was now turned inwards." ${ }^{53}$ Realizing that the identification of the pope with Antichrist had become destabilizing, Laud and the Church of England backed away from this doctrine. The Laudians also censored works that espoused this identification, editing out the relevant passages or refusing to publish them entirely. ${ }^{54}$ These efforts proved unsuccessful and the identification of the bishops of the Church of England with Antichrist soon bled into politics. Charles I, as head of the Church of England and a king with a Catholic wife, was increasingly seen as antichristian. No longer safely abroad, Antichrist was now at home. Sovereign power had been undermined and disobedience had become a religious duty. $^{55}$

While this apocalyptic message circulated among learned students of Scripture, these ideas were also able to penetrate the popular and political consciousness in Britain. With the breakdown of censorship in 1641, there was an explosion of apocalyptic prophecy, distributed mainly as pamphlets widely available to the masses. ${ }^{56}$ From late 1640 onwards, apocalyptic preachers also had the ear of Parliament. After a series of invited sermons, the House of Commons began an official program of monthly fast sermons in 1642. Most of those who preached before Parliament offered an apocalyptic interpretation of England's recent political and religious unrest. ${ }^{57}$ Stephen Marshall, a nonconformist churchman who preached to Parliament on several occasions, was particularly forceful in this interpretation. In a sermon

\footnotetext{
${ }^{52}$ Christopher Hill quotes an anonymous tract with a note that adds up the values of VVILL LAUD to 666 and adds: "I am the Beast. Count it who can / This is the number. I am the man." As quoted in Hill, The Antichrist, 68.

${ }^{53}$ Capp, "The Political Dimension," 107.

${ }_{55}^{54}$ Hoekstra, "Disarming the Prophets," 102; Hill, The Antichrist, 37.

${ }_{56}^{55}$ Hoekstra, "Disarming the Prophets," 101.

${ }^{56}$ Hoekstra, "Disarming the Prophets," 99.

${ }^{57}$ Paul Christianson notes: "Of the nineteen sermons preached to the Commons between November 1640 and January 1642, only three failed to present this apocalyptic interpretation of the 1630s." See: Christianson, Reformers and Babylon, 184, fn. 16.
} 
commemorating the accession of Queen Elizabeth I, Marshall argued that the Laudians were in league with Satan, who "knows his time is short" and therefore "stirs up all his instruments."58 Dangerous times lay ahead: "Little quiet I fear is to be expected in Christendom, till the beast his kingdom be ruined." 59 In a later sermon, Marshall urged Parliament and godly men to be unflinching in their use of divine violence. Drawing on the language and images of Psalm 137, he argued: "If this work be to avenge God's church against Babylon, he is a blessed man that takes and dashes the little ones against the stones. ${ }^{, 60}$ Parliament regularly invited preachers like Marshall, officially thanked them, and often published their sermons. ${ }^{61}$ It is therefore clear that Parliament welcomed this particular brand of apocalypticism.

Marshall's ideas were widely disseminated as fodder for the Parliamentarian cause. Edward Symmons, a royalist chaplain, begins his response to Stephen Marshall's apocalypticism with a description of an encounter with two Parliamentary prisoners in Shrewsbury in the spring of 1644. The chaplain's account of this exchange is worth quoting at length:

and questioning them about their taking up of Armes against their Soveraigne, they answered me, that they took up Armes against Antichrist, and Popery; for (said they) 'tis prophesied in the Revelation, that the Whore of Babylon shall be destroyed with fire and sword, and what doe you know, but this is the time of her ruine, and that we are the men that must help to pull her downe. I answered that the Revelation tells us, that 'tis the worke of Kings...to pull downe the whore of Babylon, to hate her, to make her naked, and to burne her with fire. But as for them, they (in my apprehension) laboured to keep up the whore of Babilon, that shee might not fall, by their endeavouring to pull downe Kings, who were appointed of God to pull downe her: they replyed, that 'tis said in the Revelation, that the People, the Multitude and Nations should also pull her downe: but I reading the verse out of one of their Bibles, shewed them their mistake, that the People, Multitude and Nations...were those whom the Whore did sit upon, and as it were did brood under her, that is, shee did rule over them, had them under their

\footnotetext{
${ }^{58}$ As quoted in Christianson, Reformers and Babylon, 185.

${ }^{59}$ As quoted in Christianson, Reformers and Babylon, 185.

${ }^{60}$ As quoted in Hill, The Antichrist, 81. The excerpt is from a 1642 sermon on Judges 5:23.

${ }^{61}$ Christianson, Reformers and Babylon, 183, Hoekstra, "Disarming the Prophets," 103; Capp, "The Political Dimension," 109.
} 
obedience, insomuch that they might rather be said to submit unto her, then to pull her downe. ${ }^{62}$

The prisoners then asked whether Symmons believed that kings can pull down the Whore of Babylon without the help of their subjects. Symmons answered: "no, nor yet the People without their Kings, who are appointed of God, to lead them thereunto, and in whole power alone it is, to Authorize people to be active and assistant in such a businesse." The chaplain went on to explain that the prisoners were mistaken in their belief that Popery was the Whore of Babylon. For, the Antichrist and the Whore "dwelt at Rome, and not here in England: and it was the very Roman seat or City which was to be so abolished." The prisoners replied "that all the true godly Divines in England (amongst them they named in speciall M. Marshall) were of the opinion, that Antichrist was here in England as well as at Rome, and the Bishops were Antichrist, and all that did endeavour to support them... and therefore they thought they were bound in conscience to fight against them."63 This exchange clearly indicates that the apocalypticism of Parliamentary preachers like Stephen Marshall had penetrated the popular consciousness and was being overtly deployed as a challenge to sovereign power.

The political use of apocalyptic ideas persisted throughout the English Civil War, as those on both sides justified their actions with reference to Revelation. Groups like the Diggers and the Levellers drew on the hopes of the apocalyptic tradition for a millennial and egalitarian future. The Fifth Monarchists were convinced that the end-times were at hand and that they would rule with Jesus in his millennial kingdom. Several Fifth Monarchists were judges at the trial of King Charles I and ultimately signed his death warrant. There is some debate about

\footnotetext{
${ }^{62}$ Edward Symmons, Scripture vindicated from the mis-apprehensions, mis-interpretations, and mis-applications of Mr. Stephen Marshall (Oxford: Leonard Lichfield, 1645), preface [electronic reproduction].

${ }^{63}$ Symmons, Scripture vindicated, preface.
} 
whether Oliver Cromwell shared the apocalyptic zeal of groups like the Fifth Monarchists. ${ }^{64}$ However, it is clear that he often closely surrounded himself with apocalypticists. Cromwell's 1649 campaign to suppress Irish Royalists was widely interpreted in apocalyptic terms. John Owen, Cromwell's friend and chaplain on this campaign, saw the Irish as the "sworn vassals of the man of sin" and "followers of the beast." 65 Cromwell himself frequently drew upon the apocalyptic imaginary in his public addresses. In a speech to the Barebones Parliament, he conveyed a sense of expectation: "Indeed I do think something is at the door. We are at the threshold...[Y] ou are at the edge of promises and prophecies.",66

Later, when Cromwell's power was formalized in the Protectorate, he would once again draw on the apocalyptic imaginary - this time to dash the millennial hopes of groups like the Diggers and the Levellers. At the opening of Parliament under the Protectorate, Cromwell quoted St. Paul's warning to Timothy: "In the last days perilous times should come, for men should be lovers of their own selves, covetous, boasters, proud, blasphemers, disobedient to parents, unthankful, \&c." He continued: "And surely it may well be feared these are our times. For when men forget all rules of law and nature...these are sad tokens of our time." ${ }^{67}$ In the end, however, Cromwell himself would be the victim of apocalyptic condemnation. The Fifth Monarchists, who had once been Cromwell's allies but were outraged by the creation of the Protectorate, eventually condemned the Lord Protector as the Beast of Revelation and actively sought to undermine his power. ${ }^{68}$ Once again, the apocalyptic imaginary refused to remain safely in sovereign hands.

\footnotetext{
${ }^{64}$ Christopher Hill, The Experience of Defeat: Milton and Some Contemporaries (New York: Viking, 1984$), 186$.

65 John Owen, as quoted in Gribben (2000a), 151.

${ }^{66}$ Oliver Cromwell, Speech to the Nominated Parliament (July 4, 1653), in The Speeches of Oliver Cromwell, ed. Ivan Roots (London: J.M. Dent and Sons, 1989), 25.

${ }^{67}$ Oliver Cromwell, Speech in the Painted Chamber to the Parliament (September 4, 1654), in The Speeches, 31.

${ }^{68}$ Capp, "The Political Dimension," 115-6.
} 


\section{Hobbes' Theological Project}

As the religious and political conflicts of the English Civil War intensified, Thomas Hobbes' political works became increasingly concerned with the challenge that these radical apocalyptic ideas posed for political order. ${ }^{69}$ At the most general level, the trajectory of Hobbes' thought during the English Civil War suggests a growing concern with the conflict between secular and religious authority. Hobbes circulated The Elements of Law, Natural and Politic on May 9, 1640, just four days after Charles I dissolved the Short Parliament. ${ }^{70}$ Only two of the work's twenty-nine chapters deal with the conflict between ecclesiastical and civil authority. ${ }^{71}$ Following a series of unsuccessful campaigns in Scotland, Charles I was forced to call The Long Parliament in November 1640. As some members of Parliament began denouncing monarchical books, Hobbes started to fear for his safety. After all, he had defended absolute sovereignty in The Elements of Law. In late November or early December 1640, Hobbes fled to Paris. There, he worked on De Cive, his next major work of political philosophy, which he published in 1642. Here, four of the eighteen chapters deal with religious matters and they are grouped in their own

\footnotetext{
${ }^{69}$ In making this argument, I am suggesting that Hobbes' argument and the rhetorical choices he makes when presenting it can only be fully understood when one takes his historical context in general and its apocalyptic elements in particular into account. This move marks an implicit rejection of an influential and ahistorical approach that focuses almost exclusively on the logical consistency and applicability of Hobbes' argument. See, for instance: David Gauthier, The Logic of Leviathan (Oxford: Clarendon, 1969). While work like Gauthier's is undoubtedly valuable, this ahistorical approach fails to recognize that the very manner in which Hobbes makes his argument and the meanings he assigns to his words are impossible to fully understand in the absence of a broader contextual understanding. Significantly, even while Hobbes himself was drawn to the ahistorical purity of abstract reasoning, he acknowledges the difficulty of determining "the opinion and meaning of those men that are gone from us long ago, and have left us no other signification therefore than their books, which cannot possibly be understood without history, to discover those aforementioned circumstances." See: Thomas Hobbes, English Works of Thomas Hobbes, vol. 4, ed. William Molesworth (London: Longman, Brown, Green, and Longmans, 1839), 75.

${ }^{70}$ This is the date in the dedication to Elements of Law. See: A.P. Martinich, Hobbes: A Biography (Cambridge: Cambridge University Press, 1999), 122.

${ }^{71}$ The chapters are Chapter 25: "That Subjects are not Bound to Follow Their Private Judgments in Controversies of Religion" and Chapter 26: "That Subjects are not Bound to Follow the Judgment of any Authorities in Controversies of Religion which is not Dependent on the Sovereign Power."
} 
section at the end of the work. Yet, as David Johnston rightly notes, "Scriptural and religious questions remained a distinctly subordinate subject in Hobbes' work." 72

This would soon change. Hobbes monitored events in England very closely during his exile. A little more than eight years into his stay in Paris, he would have received news of the execution of Charles I on January 30, 1649. Some scholars suggest that Hobbes began work on Leviathan earlier that month. ${ }^{73}$ The book was published in 1651 and contains his most extended treatment of Scriptural and religious matters. He includes a completely new chapter on religion, which he positions at the end of his account of human nature and before his description of the state of nature, which forms the basis for his theory of the origins of the commonwealth. ${ }^{74}$ The final two parts of Leviathan - "Of a Christian Commonwealth" and "Of the Kingdom of Darkness"- deal, respectively, with Scriptural interpretation and Scriptural error. These two parts occupy as much space as the first two parts on human nature and the commonwealth. Thus, as Johnston summarizes, "Scriptural and religious questions occupy more space in Leviathan than any other topic discussed in the work, including Hobbes's theory of the commonwealth itself." ${ }^{, 75}$ It is reasonable to suggest that the importance that Hobbes places on religious questions in Leviathan, and in later works like Behemoth $(1668 / 1681)^{76}$, stemmed from his realization of the central role that theological disputes played in the English Civil War.

However, Leviathan is not only Hobbes' most theological work, it is also his most eschatological. As I discuss below, he devotes substantial space to undermining the appeal of prophecy, explaining the error of the belief that the Pope is Antichrist, and de-radicalizing the

\footnotetext{
${ }^{72}$ David Johnston, The Rhetoric of Leviathan: Thomas Hobbes and the Politics of Cultural Transformation (Princeton: Princeton University Press, 1986), 114.

${ }^{73}$ Martinich, Hobbes, 213.

${ }^{74}$ Johnston, Rhetoric of Leviathan, 114.

${ }^{75}$ Johnston, Rhetoric of Leviathan, 115.

${ }^{76}$ Hobbes completed Behemoth, Or the Long Parliament in 1668, but it was not published until 1681, two years after Hobbes' death.
} 
Puritan apocalypse. While De Cive contains a chapter on Christ's kingdom on earth, Leviathan offers a much more detailed and sustained examination of Christian eschatology. This might seem to pose a problem for Hobbes scholars. As J.G.A. Pocock notes: "If we conclude that Hobbes's interest in eschatology increased between 1642 and 1651, this must have occurred during his residence in Paris, in a milieu not usually considered eschatologically-minded., ${ }^{, 77}$ Why, then, does Hobbes write his most theological and eschatological work in Paris, surrounded by intellectuals and rationalists? There are two related responses to this question. First, the character of the civil war had changed between 1642 and 1651 . The war did not begin in earnest until 1642. Hobbes may still have hoped that the King could survive this challenge. By 1651, the King had been executed, an event that shocked Royalists and moderates alike. The theological and apocalyptic arguments that had been made by Parliamentarians and their supporters demanded a response. In addition, as Pocock himself notes, by the time Hobbes published Leviathan in 1651, "the collision between private inspiration and the authority of the civil magistrate had become a staple of political debate. The far greater attention paid to apocalyptic in Leviathan than in De Cive may perhaps be a consequence of this. ${ }^{, 78}$ Second, one must not ignore the importance of Hobbes' exile from England. He followed the events of the war closely from Paris, sometimes offering written commentary on them. ${ }^{79}$ Growing increasingly uncomfortable and anxious in France, he watched as the situation in England continued to deteriorate. He was caught between a home to which he felt he could not return and an adopted country that was increasingly targeting those who, like him, were critical of Catholicism. The fact that he wrote his most eschatological work in exile puts Hobbes in the

\footnotetext{
${ }^{77}$ J.G.A Pocock, "Time, History and Eschatology," 173, fn. 41. I would like to thank Joshua Foa Deinstag for first alerting me to this concern.

${ }_{78}^{78}$ Pocock, "Time, History and Eschatology," 180.

${ }^{79}$ For instance, Hobbes read and responded to an April 1641 petition to abolish the episcopacy. See: Martinich, Hobbes, 171.
} 
best apocalyptic company — alongside Daniel, John of Patmos, and the Marian exiles, whose work while abroad was motivated by political developments at home.

Hobbes' response to the apocalypticism of the English Civil War is idiosyncratic and complex. He combats the politically destabilizing potential of the apocalyptic imaginary not by trying to escape it or condemn it but by attempting to put it back in the service of sovereign power. ${ }^{80}$ Hobbes pursues two paths to this end-one that is overtly theological and another that is seemingly secular. This section of the chapter traces the first path, while the next explores the second. In examining Hobbes' theological response to the apocalyptic imaginary, I argue that he denounces apocalypse with apocalypse. He condemns the radical Puritan apocalypse as false and reveals a "true" apocalypse that has been safely returned into sovereign hands. ${ }^{81}$ Hobbes does this by attacking false prophets, narrowing the definition of Antichrist, and offering an alternative Christian eschatology. ${ }^{82}$ Yet, with each of these moves, the radical apocalyptic imaginary seems to escape Hobbes' attempt to control and subdue it. This hardly seems surprising, given that throughout the civil war and afterward, the apocalyptic imaginary had tended to resist and escape efforts at sovereign control.

\footnotetext{
${ }^{80}$ By his own principles, Hobbes is not in a position to reject the apocalypse entirely. Those claiming that the end times were imminent during the English Civil War drew support for these prophetic assertions from Revelation. One possible route to deflating these claims might have been to challenge the canonicity of Revelation. Erasmus had done this by denying that John the Evangelist wrote Revelation. However, this route is not available to Hobbes, for whom matters of canonicity are determined by the sovereign. Hobbes' sovereign had pronounced on this matter. Revelation was conical. This may be one reason why Hobbes is compelled to fight apocalypse with apocalypse. See: Hoekstra, "Disarming the Prophets,"109, fn. 60.

${ }^{81}$ This move of denouncing false apocalypses is, for Derrida, one of the defining features of the apocalyptic tone. After pointing to the focus in Revelation on identifying and testing false apostles and envoys, he asks: "Shall we thus continue in the best apocalyptic tradition to denounce false apocalypses?" See: Jacques Derrida, "Of an Apocalyptic Tone Newly Adopted in Philosophy," in Derrida and Negative Theology, eds. Harold Coward and Toby Foshay. (Albany: State University of New York Press, 1992), 59.

${ }^{82}$ In pursuing this line of argument, I am suggesting, along the lines of J.G.A. Pocock, that Hobbes' eschatological argument in the last two books of Leviathan is worthy of serious attention from political theorists. When Pocock first published his analysis of Hobbes' eschatology, very little work had been done in this area. Pocock summarizes the scholarship as follows: "The two books in which Hobbes expounds Christian faith and its sacred history are almost exactly equal in length to Books I and II [of Leviathan]; yet the attitude of far too many scholars towards them has traditionally been, first, that they aren't really there, second, that Hobbes didn't really mean them." See: Pocock, "Time, History and Eschatology," 161-2. This situation is now being remedied in the Hobbes scholarship, but more slowly than one might have hoped.
} 
As we have seen, the breakdown of censorship in 1641 led to the explosion of apocalyptic prophecy in England. Distributed as pamphlets, these prophecies became widely available to the masses. In addition, Parliament opened its doors to apocalyptic preachers who prophesied and encouraged an unrestrained outpouring of divine violence in preparation for a new millennium.

While Hobbes identified these developments as threats to political order, he certainly understood the appeal of prophecy. For him, the roots of religious belief lie in man's Promethean condition, his inescapable tendency to look "too far before him, in the care of future time" and therefore to have "his heart all the day long gnawed on by fear of death, poverty, or other calamity." ${ }^{\prime 83}$ Hobbes will go on to argue that this same anxiety about the future can be harnessed to get men to accept an absolute sovereign. ${ }^{84}$ But it can also bring them under the power of selfproclaimed prophets offering a compelling interpretation of the crises of the present and a captivating vision for a new future. In Hobbes' time, these prophets claimed divine inspiration from God or special insight into Scripture to authorize their claims. The performance of this divine inspiration carried special appeal. The radical Puritan preachers, Hobbes explains, "used the Scripture phrase (whether understood by the people or not), as no tragedian in the world could have acted the part of a right godly man better than these did." ${ }^{25}$ They feigned divine inspiration, giving their sermons the appearance of spontaneity, as if they had in that very moment been "dictated by the spirit of God within them." ${ }^{86}$ The prophets and preachers of

\footnotetext{
${ }^{83}$ Thomas Hobbes, Leviathan, ed. Edwin Curley (Indianapolis: Hackett Publishing Company, 1994), book I, chapter 12, paragraph 5, page 64. Future references to Leviathan will take the following form: I.12.5, 64 .

${ }^{84}$ Stephen Holmes put its well: "If the yet unreal future had no causal power, human beings could never be moved by threats of punishment or fear of violent death." See: Stephen Holmes, "Introduction," in Behemoth or the Long Parliament (Chicago: Chicago University Press, 1990), xiv.

${ }^{85}$ Thomas Hobbes, Behemoth or the Long Parliament (Chicago: Chicago University Press, 1990), dialogue I, page 24. Future references to Behemoth will take the following form: I, 24.

${ }^{86}$ Hobbes, Behemoth, I, 25.
} 
Hobbes' day appealed to a human anxiety about the future and offered an apocalyptic vision of the time to come. ${ }^{87}$

For Hobbes, the problem here concerns divided allegiance. Both the prophet and the sovereign appeal to our anxiety about the future. When what they each ask of us is contradictory, the decision about whom to obey could then rest on whose vision of the future is more compelling. As Stephen Holmes explains, "the struggle for sovereignty is fought on a battlefield of wholly unreal imaginings or rationally unjustifiable assumptions about the future. Whoever controls the future (or the idea people have of the future) has unstoppable power." ${ }^{, 88}$ Because the prophet can offer us a different and perhaps more compelling vision of the future than the one our sovereign provides, the former can undermine civil sovereignty by dividing our allegiances. For Hobbes, "the most frequent pretext for sedition and civil war, in Christian commonwealths, hath a long time proceeded from a difficulty, not yet sufficiently resolved, of obeying at once both God and man... when their commandments are contrary to one another." 89 The claim of the prophet to speak in God's name allies him with the divine and reduces the sovereign to the status of a mere "man." This problem is made worse by our inability or unwillingness to question those who claim to speak in God's name. Dazzled by a prophetic

\footnotetext{
${ }^{87}$ For Hobbes, the fault here does not lie entirely with self-proclaimed prophets and their cunning uses of rhetoric, but also with fundamental tendencies of human nature. This marks an important shift for Hobbes. In his earlier work, The Elements of Law, he crafted a strong opposition between reason and rhetoric and attributed man's outbursts of irrationality to shrewd rhetoricians. "And such is the power of eloquence," explains Hobbes, "as many times a man is made to believe thereby, that he sensibly feeleth smart and damage, when he feeleth none, and to enter into rage and indignation, without any other cause, than what is in the words and passion of the speaker." [Thomas Hobbes, The Elements of Law, Book II, Chapter 8, Para 14, electronic edition]. However, by the time Hobbes comes to consider the problem of prophecy in Leviathan, the use of rhetoric is not the only, or even the primary, culprit for man's irrationality. The main source of irrationality is the power of superstitious and magical beliefs. While they can manipulate such beliefs, rhetoricians do not create them. Rather, these beliefs emerge from a basic human fear of the unknown. "Ignorance of natural causes disposeth a man to credulity, so as to believe many times impossibilities." This ignorance of natural causes, along with men's failure to remedy it, instills a fear "of what it is that hath the power to do them much good or harm [and they] are inclined to suppose and feign unto themselves several kinds of powers invisible, and stand in awe of their own imaginations" [Hobbes, Leviathan, I.11.23-25, 62]. This analysis is drawn from Johnston, Rhetoric of Leviathan, 60-1, 106-8.

${ }^{88}$ Holmes, "Introduction," xiv.

${ }^{89}$ Hobbes, Leviathan, III.43.1, 397.
} 
vision of the future, men may fail to identify the "many false prophets...that seek reputation with the people by fantastical and false doctrines, and by such reputation...govern them for their private benefit." ${ }^{90}$ Their anxiety about the future and their reverence toward those who claim to speak in God's name leads men astray, away from the proper obedience owed to their sovereign and toward rebellion and civil war.

Hobbes' solution to this problem is to identify those who claim to speak in the name of God against the sovereign as "false prophets." In making this denouncement, Hobbes has aligned himself with a rich Christian apocalyptic tradition of identifying false prophets announcing the imminent end of the known world. ${ }^{91}$ Consistent with this tradition, Hobbes demands that we test those who claim to be prophets. Anyone claiming to speak in the name of God is "worthy to be suspected of ambition and imposture, and consequently, ought to be examined and tried by every man before he yield them obedience. ${ }^{, 92}$ Hobbes first asks men to use their reason to assess what the prophet is telling them and whether this should command belief or adherence. To those prophets who claim that God has spoken to them through Scripture, Hobbes responds that this is no different than the manner in which God speaks to "all other Christian men. ${ }^{93}$ The prophet claiming inspiration from Scripture can therefore have no special status or authority. To the prophet claiming divine inspiration through a dream, Hobbes wryly responds: "to say he hath spoken to him in a dream is no more than to say he dreamed that God spake to him, which is not of force to win belief." 94 A prophet who claims to have had

\footnotetext{
${ }^{90}$ Hobbes, Leviathan, III.43.1, 397.

${ }^{91}$ Chapters 2 and 3 of Revelation deal with false prophets and a duty of perseverance. Similarly, the "miniapocalypse' in Matthew warns that "many shall come in my name, saying, I am Christ; and shall deceive many" and "many false prophets shall rise, and shall deceive many" $(24: 5,11)$.

${ }^{92}$ Hobbes, Leviathan, III.36.19, 290.

${ }^{93}$ Hobbes, Leviathan, III.32.6, 247.

${ }^{94}$ Hobbes, Leviathan, III.32.6, 247.
} 
waking visions may do so because he has failed to observe "his own slumbering." 95 Similarly, the prophet's claim of supernatural inspiration may merely amount to "an ardent desire to speak, or some strong opinion of himself, for which he can allege no natural and sufficient reason." 96

Not confident in man's capacity to rationally assess prophetic claims, Hobbes offers a more concrete test for identifying false prophets. He argues that Scripture provides "two marks by which together, not asunder, a true prophet is to be known. One is the doing of miracles; the other is not teaching any other religion than that which is already established." 97 In line with the contemporary doctrine of the Church of England, Hobbes declares that miracles no longer happen. They ceased because belief in miracles was not necessary for salvation after the work of Jesus and Scripture was finished. The Bible supplies the place of miracles and recompenses "the want of all other prophecy, and from which, by wise and learned interpretation and careful ratiocination, all rules and precepts necessary to the knowledge of our duty both to God and man, without enthusiasm or supernatural inspiration, may be easily deduced." 98 The cessation of miracles alone means that no self-proclaimed prophet can meet Hobbes' test, as the two marks of prophethood must both be present. Nevertheless, Hobbes also addresses the second mark of a prophet-his consistency with established religious doctrine. The responsibility for establishing

\footnotetext{
${ }^{95}$ Hobbes, Leviathan, III.32.6, 247.

${ }^{96}$ Hobbes, Leviathan, III.32.6, 247.

${ }^{97}$ Hobbes, Leviathan, III.32.7, 247-8. Hobbes draws these criteria from Deuteronomy 13:1-5: "If there arise among you a prophet, or a dreamer of dreams, and giveth thee a sign or a wonder, And the sign or the wonder come to pass, whereof he spake unto thee, saying, Let us go after other gods, which thou hast not known, and let us serve them; Thou shalt not hearken unto the words of that prophet, or that dreamer of dreams: for the LORD your God proveth you, to know whether ye love the LORD your God with all your heart and with all your soul. Ye shall walk after the LORD your God, and fear him, and keep his commandments, and obey his voice, and ye shall serve him, and cleave unto him. And that prophet, or that dreamer of dreams, shall be put to death; because he hath spoken to turn you away from the LORD your God, which brought you out of the land of Egypt, and redeemed you out of the house of bondage, to thrust thee out of the way which the LORD thy God commanded thee to walk in. So shalt thou put the evil away from the midst of thee."

${ }^{98}$ Hobbes, Leviathan, III.32.8, 249. For a discussion of the cessation of miracles as Church of England doctrine and the debates among Protestants about this doctrine, see: Jane Shaw, Miracles in Enlightenment England (New Haven: Yale University Press, 2006), 21-50.
} 
and defending doctrine rests entirely with the sovereign. Like Moses, the sovereign of a Christian commonwealth is the sole interpreter of God's commands:

no man ought in the interpretation of the Scripture to proceed further than the bounds which are set by their several sovereigns. For the Scriptures, since God now speaketh in them, are the Mount Sinai, the bounds whereof are the laws of them that represent God's person on earth. To look upon them, and therein to behold the wondrous works of God, and learn to fear them, is allowed; but to interpret them, that is to pry into what God saith to him whom he appointeth to govern under him, and make themselves judges whether he govern as God commandeth him or not, is to transgress the bounds God hath set us, and to gaze upon God irreverently. ${ }^{99}$

Thus, those who claim prophetic status while attempting to subvert the religious interpretation established by the sovereign must necessarily be false prophets.

This attempt to eliminate the subversive potential of prophecy would, if successful, go some way towards undermining the radical and antinomian potential of the apocalyptic imaginary. Those claiming the status of apocalyptic prophets must, on Hobbes' criteria, be false prophets. But Hobbes' method here rests uneasily with this own diagnosis of the religious unrest of the English Civil War. His argument about false prophets relies on man's ability to rationally assess prophetic claims or, barring that, to simply accept that miracles have now ceased and that his sovereign is the only legitimate interpreter of Scripture. This kind of blind obedience is itself rational, if we agree with Hobbes that the sovereign is the only entity capable of rescuing man from the state of nature and a constant fear of violent death. Yet the godly men of the civil war succeeded, according to Hobbes, because they appealed not to reason but to the imagination. Drawing on man's anxiety toward the future, they offered a captivating apocalyptic interpretation of the crises of the present and the promises of the time to come. And they captivated by virtue of their performance, their ability to play the part of the godly man and to enact moments of divine inspiration. These performances were so convincing that their content

\footnotetext{
${ }^{99}$ Hobbes, Leviathan, III.40.7, 321.
} 
became less important than their source. Hobbes explains, "I think that neither the preaching of friars nor monks, nor of parochial priests, tended to teach men what, but whom to believe. For the power of the mighty hath no foundation but in the opinion and belief of the people."100 The basis for authority, then, "is not coercion of the body but captivation of the mind." wondering whether Hobbes' denouncement of false prophets and tests for the assessment of prophetic claims can adequately deal with the real threat of radical apocalyptic prophecy-its capacity to captivate the imagination and provoke belief.

Having attempted to undermine prophetic claims, Hobbes directs his attention to the particular content of the prophecies that helped animate the civil war. In the lead up to the civil war, the doctrine that the pope was Antichrist had gained wide mainstream acceptance. This became a particular problem for England when Archbishop Laud and his followers initiated reforms that were seen by many as undoing the work of the Reformation and bringing the Church of England closer to the Roman Catholic Church. If the pope and the papacy were Antichrist and the Church of England had become "popish," then the agents of Antichrist must be in England. With the dissolution of censorship and rising religious tensions, "the explosive accusation of antichristianity could be levelled against anything one disliked, so it was necessary to pin [the accusation] down as something politically harmless." ${ }^{102}$ This is precisely what Hobbes attempts to do.

\footnotetext{
${ }^{100}$ Hobbes, Behemoth, I, 16. As Stephen Holmes points out, this statement raises important questions about the centrality of rational self-interest and self-preservation in Hobbes' political theory. The account of human motivation in Behemoth, as well as in the last two books of Leviathan, raises serious questions about what Hobbes takes to be the true foundation of political authority. Holmes: "Human behavior, no matter how self-interested, remains unpredictable because it is guided partly by assessments of the future, assessments that, in turn, result from irrational traits of the mind (naïve trust in prognostications, a gloomy disposition, etc.), not from the calculations of a rational maximizer." See Holmes, "Introduction," xv.

${ }^{101}$ Holmes, "Introduction," xi.

${ }^{102}$ Hoekstra, "Disarming the Prophets," 107.
} 
He addresses this question in a lengthy chapter of Leviathan that responds to the arguments of Cardinal Bellarmine, a prominent defender of the authority of the pope in secular matters. Most of the chapter deals with Bellarmine's individual claims and reasserts and develops Hobbes' argument that ecclesiastical power does not extend to secular matters. However, when he reaches the point in Bellarmine's argument where the cardinal deals with the question of whether the pope is Antichrist, Hobbes becomes conciliatory. "For my part," he explains, "I see no argument that proves he is so, in that sense the Scripture useth the name, nor will I take any argument from the quality of Antichrist to contradict the authority he exerciseth, or hath heretofore exercised in the dominions of any other prince or state." 103 While Hobbes aggressively defends the jurisdiction of civil sovereigns against papal interference, he will not base his argument on an identification of the pope with Antichrist. Hobbes then makes an additional move to render Antichrist politically impotent. Appealing to Scripture, he argues that Antichrist must possess two characteristics: "one, that he denieth Jesus to be the Christ; and another that he professeth himself to be Christ." ${ }^{\prime 104}$ From these two attributes of Antichrist, a third follows: "he must also be an adversary of Jesus the true Christ, which is another usual signification of the word Antichrist."

Clearly, then, the Pope cannot be Antichrist, as he does not claim to be Christ, nor does he deny that Jesus is the Christ. While the pope is illegitimately usurping the power of Christian kings, "he doth it not as Christ, but as for Christ, wherein there is nothing of The Antichrist." 106 Hobbes' narrowing of the definition of Antichrist does not only exclude the pope. It also

\footnotetext{
${ }^{103}$ Hobbes, Leviathan, III.42.87, 376-77.

${ }^{104}$ Hobbes, Leviathan, III.42.88, 377. Hobbes bases the first characteristic on a passage from 1 John: "Every Spirit that confesseth not that Jesus Christ is come in the flesh, is not of God; and this is the spirit of Antichrist" (4:3). He bases the second characteristic on two passages from Matthew: "Many shall come in my name, saying, I am Christ" (24:5) and "If any man shall say unto you, lo! here is Christ, there is Christ, believe it not" (24:23).

${ }^{105}$ Hobbes, Leviathan, III.42.88, 377. Emphasis in original.

${ }^{106}$ Hobbes, Leviathan, III.42.88, 378. Emphasis in original.
} 
excludes Archbishop Laud, the episcopacy of the Church of England, the royalists, and the parliamentarians, none of whom claimed to be Christ or denied that Jesus is the Christ. The requirement that Antichrist claim to be Christ further excludes the non-Christians historically identified as Antichrist, like Muslims or "Turks." Hobbes thus excludes "almost any conceivable Christian or non-Christian" from the category of Antichrist. ${ }^{107}$ The true Antichrist will come at the end of days, "but that tribulation is not yet come."108 We will know when it does because we will witness "such tribulation as was not [seen] since the beginning of the world," followed by "a darkening of the sun and moon, a falling of the stars, and a concussion of the heavens, and the glorious coming again of our Saviour in the clouds." 109 And if we should be in any doubt about this, we must always remember that our sovereign is the only legitimate interpreter of Scripture. Thus, the king himself has the authority "to determine whether or not he [himself] is the Antichrist predicted in the New Testament. And one could expect the stars to fall well before he would give an affirmative answer to this question." ${ }^{110}$ With this, Hobbes appears to conclude that the matter is closed. Antichrist has successfully been divested of its subversive potential.

Once again Hobbes has offered a rational argument in order to render politically impotent a figure that captures the imagination. Accusations that the pope or the Laudian Church or Cromwell was Antichrist did not work at the level of rational persuasion. Rather, they captivated people by drawing on an apocalyptic imaginary that envisioned a final and bloody struggle between the forces of good and evil. Hobbes' attempt to suck the subversive power from Antichrist is subject to the same criticism as his arguments about false prophecy-it does not

\footnotetext{
${ }^{107}$ Hoekstra, "Disarming the Prophets," 108.

${ }^{108}$ Hobbes, Leviathan, III.42.88, 378.

${ }^{109}$ Hobbes, Leviathan, III.42.88, 378.

${ }^{110}$ Hoekstra, "Disarming the Prophets," 109.
} 
adequately acknowledge the imaginative bases of religious conviction. The accusation that the pope was Antichrist did not take the form of an argument. Rather, it relied on a series of imagistic associations. In the annotations to the Geneva Bible, the first Beast in Revelation 13 is the Roman Empire, the "Whore of Babylon." The second Beast, who "exerciseth all the power of the first beast before him," ${ }^{111}$ is then the Roman Catholic Church. It is hard to know how Hobbes expected an argument about the nature of Antichrist to undermine the captivating images at work in the apocalyptic imaginary. Indeed, even Hobbes himself is captivated by the image of the Catholic Church swallowing up the authority of the Roman Empire. For, as he famously declares, "the Papacy is no other than the ghost of the deceased Roman empire, sitting crowned upon the grave thereof. For so did the Papacy start up on a sudden out of the ruins of that heathen power." ${ }^{\prime 12}$ It is precisely this imaginative association that lay at the root of the claims that the pope was Antichrist. Despite his argument that the pope cannot possibly be Antichrist, it seems that Hobbes too is captivated by the imagery of the apocalypse. In the throes of this captivation, he offers us one of the most enduring images from Leviathan, and one that is all the more memorable for the fact that it is embedded in a theological argument that is largely devoid of appeals to the imagination.

Hobbes' final theological response to apocalypticism takes the form of an alternative Christian eschatology that has been divested of its subversive potential. Two features of this alternative eschatology are particularly important for our analysis here. First, Hobbes attempts to undermine claims that the apocalypse is imminent. Before and during the English Civil War, many apocalyptic prophets had claimed that England was experiencing the end of days foretold

\footnotetext{
${ }^{111}$ Revelation 13:12 and Geneva Bible (1599), notes on Revelation 13:12.

${ }^{112}$ Hobbes, Leviathan, IV.47.21, 483. Pocock calls this "a superb historical image and a piece of secularized apocalyptic - the new Babylon arisen in place of the old and sitting upon seven hills." See: Pocock, "Time, History and Eschatology," 194.
} 
in Revelation. This lent a sense of divine urgency and importance to England's struggles and was often used to lend the violence of war a sacred legitimacy. Those who might have been unwilling to challenge sovereign power under "normal" circumstances were enticed to rebellion by a belief that they were participating in a final battle, after which there would be peace in a New Jerusalem. Hobbes responds to this belief in an imminent apocalypse by condemning it as blatantly false. He explains that the "second coming, not yet being, the kingdom of God is not yet come, and we are not now under any other kings by pact, but our civil sovereigns." ${ }^{" 13}$ As Hobbes tells us, we will know when the apocalypse begins because the sun and moon will darken and the stars will fall. It is not in our power to hasten or predict the arrival of the last days. Drawing on Scripture, Hobbes summarizes Christ's position: "my kingdom is not yet come, nor shall you foreknow when it shall come; for it shall come as a thief in the night."114 In making this argument, Hobbes is adopting a conservative eschatology that is similar to that of St. Augustine. In colloquial terms, the argument amounts to this: the apocalypse will come, but we can never understand it to be happening here and now.

Hobbes' second move in offering an alternative eschatology is more original. Apocalyptic prophets and godly men held sway during Hobbes' time not only because they held out the hope for a millennial future but also because they wielded the threat of eternal damnation. Failure to participate in the battles of the last days would ensure one a place in the fiery depths of hell. This was indeed a menacing threat. For his part, the only viable threat the sovereign can make is to punish disobedience with death. The clear imbalance in the power of these two threats is politically destabilizing. When the dictates of those threatening eternal damnation conflict with those of the sovereign, who can only threaten death, it is clear whose demands will

\footnotetext{
${ }^{113}$ Hobbes, Leviathan, IV.44.4, 413.

${ }^{114}$ Hobbes, Leviathan, IV.44.18, 422. Hobbes echoes Paul (1 Thess. 5:2) here.
} 
triumph. "For no man can serve two masters; nor is he less, but rather more a master, whom we believe we are to obey for fear of damnation, than he whom we obey for fear of temporal death." 115 Hobbes recognizes that this imbalance of threat lies at the origins of the political chaos of the civil war. He notes: "as much as eternal torture is more terrible than death, so much they would fear the clergy more than the King." $" 116$ Indeed, there is hardly anything that could be more damaging to sovereignty than that "men should, by the apprehension of everlasting torments, be deterred from obeying their princes." ${ }^{117}$

It is difficult to overestimate the importance of this problem for Hobbes' political argument. The fear of death is the primary passion inclining men to peace and therefore to the acceptance of sovereign authority. ${ }^{118}$ For Hobbes, this passion is so fundamentally legitimate and reasonable that it can totally excuse those who violate the laws of the sovereign "by the terror of present death... because no law can oblige a man to abandon his own preservation."119 Fear of death is therefore the basis of Hobbes' political argument about the grounds and reach of sovereign power "and of his view of the irreducible liberty of subjects." 120 The problem is that death is not the only object of human fear. Hobbes explains: "The passion to be reckoned upon is fear; whereof there be two very general objects: one, the power of spirits invisible; the other, the power of those men they shall therein offend." In this passage and elsewhere in Leviathan,

\footnotetext{
${ }^{115}$ Thomas Hobbes, De Cive, in Man and Citizen, ed. Bernard Gert (Indianapolis: Hackett, 1991), chapter 6, section 11, page 179. Future references to De Cive will take the following form: 6.11, 179.

${ }^{116}$ Hobbes, Behemoth, I, 14-5. Here, Hobbes echoes the advice of Matthew 10:28: "And fear not them which kill the body, but are not able to kill the soul: but rather fear him which is able to destroy both soul and body in hell."

${ }^{117}$ Hobbes, De Cive, 12.5, 248. This is echoed in Leviathan: "The maintenance of civil society depending on justice, and justice on the power of life and death (and other less rewards and punishments) residing in them that have the sovereignty of the commonwealth, it is impossible a commonwealth should stand where any other than a sovereign hath a power of giving greater rewards than life, and of inflicting greater punishments than death." See: Hobbes, Leviathan, III.38.1, 301.

${ }^{118}$ Hobbes, Leviathan, I.13.14, 78. I borrow much of the analysis in this paragraph from Johnston, 98-101.

${ }^{119}$ Hobbes, Leviathan, II.27.25, 198.

${ }^{120}$ Johnston, Rhetoric of Leviathan, 101.
} 
Hobbes treats the latter as "the greater fear." ${ }^{121}$ However, when he comes to consider the forces that threaten a commonwealth, he admits that the fear of spirits may in fact be the greater fear. When civil and spiritual powers come into conflict, the former will draw more people because the civil authority is "more visible" and stands "in the clearer light of natural reason." Yet the spiritual power may still attract "a party sufficient to trouble, and sometimes to destroy a commonwealth" because "the fear of darkness and ghosts is greater than other fears." 122 This is a remarkable admission. It calls into question the behavioral basis of Hobbes' account of sovereign power. It suggests a fundamental disjunction between men as they are-fearful of invisible things, like the fiery pits of hell—and men as they should be, according to Hobbes' political theory—rational, egoistic beings who are primarily motivated by a fear of death.

Hobbes responds to the problem of the fear of eternal damnation by offering an alternative account of the Day of Judgment that denies the possibility of hell and everlasting torment. According to Hobbes, we will all die a corporeal death. Upon Christ's return to earth, our bodies will be resurrected and we will be judged. The righteous "shall have their bodies suddenly changed, and made spiritual and immortal." ${ }^{23}$ However, the sinners will not be subjected to eternal torments. Their punishment is simply that they undergo a second death. Hobbes cites those passages of the Bible that refer to unquenchable fire, weeping, and gnashing of teeth, but concludes that the pain mentioned there is metaphorical. It is a metaphor "for a grief and discontent of mind, from the sight of that eternal felicity in others which they themselves through their own incredulity and disobedience have lost." ${ }^{, 24}$ Upon witnessing the felicity of the elect, each wicked man will suffer a second death "after which he shall die no

\footnotetext{
${ }^{121}$ Hobbes, Leviathan, I.14.31, 88.

${ }^{122}$ Hobbes, Leviathan, II.29.15, 216.

${ }^{123}$ Hobbes, Leviathan, IV.44.27, 427.

${ }^{124}$ Hobbes, Leviathan, III.38.14, 309.
} 
more." ${ }^{, 25}$ It is inconceivable, Hobbes adds later, that a merciful God "should punish men's transgressions without any end of time, and with all the extremity of torture that men can imagine, and more."126

This still leaves Hobbes with the challenge of dealing with those parts of the Bible that suggest that the fires and torments are everlasting. He responds that they are endless because there will be a perpetual supply of the damned: "For the wicked, being left in the estate they were in after Adam's sin, may at the resurrection live as they did, marry, and give in marriage, and have gross and corruptible bodies... and consequently may engender perpetually, after the resurrection as they did before." The children of the damned "are not worthy to be counted amongst them that shall obtain the next world, and an absolute resurrection from the dead; but only a short time, as inmates of that world, and to the end only to receive condign punishment for their contumacy." 127 The punishment and torment of a second death will last, "by the succession of sinners thereunto, as long as the kind of man by propagation shall endure, which is eternally." ${ }^{28}$ In short, Biblical references to everlasting torments are not meant to suggest that such punishment is everlasting for any particular person, but rather that the generations of the damned will be perpetually replenished. In promising us merely a second death, rather than everlasting torment, Hobbes thus attempts to remove the threat of eternal damnation from the arsenal of those who urge us to act against our sovereign in the name of faith.

Once again, Hobbes gives reasons and arguments to counteract a threat that plays on the imagination and draws on our deepest fears about endless torture. He presents some of the most terrifying imagery of the Christian bible and then asks his reader to rationally assess the degree

\footnotetext{
${ }^{125}$ Hobbes, Leviathan, III.38.14, 309.

${ }^{126}$ Hobbes, Leviathan, IV.44.26, 426.

${ }^{127}$ Hobbes, Leviathan, IV.44.29, 428.

${ }^{128}$ Hobbes, Leviathan, IV.44.29, 429.
} 
to which those images logically square with the existence of a merciful God. Even if we grant that Hobbes' attempt to eliminate hell from the Christian account of the Last Days has been successful, at best he has only leveled the playing field between prophets and preachers, on the one hand, and the civil sovereign, on the other. Both are capable of threatening death in exchange for disobedience. Hobbes is thus back in a position which he has consistently tried to avoid - one in which the godly and the sovereign can make equal claims upon us. And given the choice between an ordinary death at the hands of one's sovereign and a second death in the sight of an enthroned and judging Christ and his elect, the former may still be vastly preferable to the latter. If one adds to this the utter hopelessness of the knowledge that, once damned, one will beget children who will likewise be "doomed to perish utterly without help from the God who visibly and humanly reigns over them," ${ }^{129}$ death at the hands of one's sovereign may be a welcome fate. $^{130}$

Thus, Hobbes' attempt to offer an alternative Christian eschatology to counteract the radical apocalyptic imaginary is problematic on Hobbes' own terms. The apocalyptic prophets of the English Civil War had offered visions that captivated the imagination, eliciting the deepest fears of their audiences in order to provoke belief. Hobbes offers arguments to combat captivation, reasons to undermine fear, and Scriptural analysis to counter belief. At every move, the apocalyptic imaginary seems to escape his efforts to control and subdue it. In his theological arguments, Hobbes is never quite able to overcome apocalypticism's capacity to captivate the imagination.

\footnotetext{
${ }^{129}$ Pocock, "Time, History and Eschatology," 175.

${ }^{130}$ Hobbes himself seems to have realized that the sexuality of the damned undermined his attempt to offer a more humane account of hell. The 1668 Latin Leviathan omits references to the sexuality of the damned. A.P. Martinich suggests that Hobbes' account of the endless regeneration of the damned "was undoubtedly an unfortunate view. What started off as a humane reinterpretation of hellfire went seriously wrong. There is not enough difference between the eternal suffering of some people and the finite but intense suffering of an infinite number of people. Hobbes eventually came to see that his views about eternal flames were not acceptable." See: Martinich, Hobbes, 251.
} 
This criticism may strike some as unfair. ${ }^{131}$ If Hobbes intended that his theological argument be read by learned students of Scripture and intellectuals, then surely his strategy of offering Scripturally based arguments is a reasonable one. After all, these are not the "simple people" who are regularly abused by "crafty ambitious persons" wielding prognostications and false prophecies. ${ }^{132}$ They are those who have overcome their "superstitious fear of spirits" and "powers invisible." $" 133$ However, it is not at all clear that Hobbes had such a restricted view of the audience of Leviathan. There are certainly moments in this text where Hobbes seems to suggest that he intends the work to be read by a very select audience - sovereigns or university men. ${ }^{134}$ Yet the fact that the work was published in English and distributed widely points to Hobbes' effort to expand his audience. He did not have The Elements of Law printed, but rather circulated it among his friends. Hobbes did have De Cive printed, but circulated it only among a small group of international scholars. Both pieces were printed in Latin-a decision that opened Hobbes' work to international scrutiny, but that limited the size of his audience substantially. Leviathan seems aimed a broader audience — the English reading public.

However, Hobbes gives important indications that while the audience of the text of Leviathan may be limited to the reading public, the intended audience for the book's philosophy is even larger. Because they are either too busy or too lazy to engage in "deep meditation...in the matter of natural justice," most men "receive the notions of their duty chiefly from divines in

\footnotetext{
${ }^{131}$ I would like to thank Dwight Allman and Matthew Evangelista for raising the questions to which I attempt to respond in the following three paragraphs.

${ }_{132}^{132}$ Hobbes, Leviathan, I.2.8, 11.

${ }^{133}$ Hobbes, Leviathan, I.2.8, 11; II.11.26, 62.

${ }^{134}$ For an argument that Hobbes wrote Leviathan for sovereigns or potential sovereigns, see: Gary Shapiro, "Reading and Writing in the Text of Hobbes's Leviathan," Journal of the History of Philosophy, 18, no. 2 (1980): 151. For an argument that Hobbes wrote Leviathan for the purpose of having the book taught in universities, see: Tracy Strong, "How to Write Scripture: Words, Authority, and Politics in Thomas Hobbes," Critical Inquiry, 20, no. 1 (1993): 131, 159. For an assessment of these arguments, among others, see: Geoffrey M. Vaughan, "The Audience of Leviathan and the Audience of Hobbes's Political Philosophy," History of Political Thought 22, no. 3 (2001): 448-471. My analysis in the following three paragraphs draws heavily on that of Vaughan.
} 
the pulpit, and partly from such of their neighbours or familiar acquaintance as having the faculty of discoursing readily and plausibly seem wiser and better learned in such cases of law and conscience than themselves." "135 The goal of Leviathan is to provide the "wiser and better learned" the tools with which to acquaint others with their duties. At the end of Leviathan, Hobbes reflects that his doctrine might profitably be "taught in the Universities," which "are the fountains of civil and moral doctrine, from whence the preachers and the gentry, drawing such water as they find, use to sprinkle the same (from both the pulpit and in their conversation) upon the people."136 These remarks suggest that while the audience for the text of Leviathan was limited to the reading public, the intended audience for Hobbes' ideas was much larger.

This expanded conception of Hobbes' audience explains many of the particular features of Leviathan - its rhetorical qualities ${ }^{137}$, its memorable title and frontispiece, and its powerful use of imagery, particularly in the first two books. Hobbes is providing his readers with ways to communicate his ideas to the masses, who have neither the time nor the inclination to increase

\footnotetext{
${ }^{135}$ Hobbes, Leviathan, II.30.14, 225.

${ }^{136}$ Hobbes, Leviathan, Review and Conclusion, para. 16, 496.

${ }^{137}$ Hobbes' use of rhetoric in Leviathan has received substantial scholarly attention. For many of these scholars, Leviathan marks a shift in Hobbes' style from his earlier, more "scientific" works like Elements of Law and De Cive. While Leviathan contains some of Hobbes' most memorable denunciations of rhetoric, it also deploys rhetorical techniques like metaphor much more freely and comfortably than his earlier works. David Johnston argues that Hobbes intended Leviathan as a political act designed to initiate a "cultural transformation through which Hobbes hoped to lay the foundations required for any truly rational polity to come into being" (xx). Hobbes deploys his early humanist education in rhetoric because he has come to understand the power of public opinion and has come to consider rationality as something that is artificial, rather than natural. See: Johnston, Rhetoric of Leviathan, 66-133. Quentin Skinner argues, along somewhat similar lines, that Elements of Law and De Cive mark a "scientific" phase in Hobbes' writing during which he was confident that rational argument alone could be persuasive. However, by the time he wrote Leviathan, Hobbes was convinced that reason could do little without rhetoric. Thus, for Skinner, "Leviathan constitutes a belated but magnificent contribution to the Renaissance art of eloquence." See: Quentin Skinner, Reason and Rhetoric in the Philosophy of Thomas Hobbes (Cambridge: Cambridge University Press, 1997), 4. Bryan Garsten offers a useful and persuasive critique of Skinner's position. Garsten notes that "the mere presence of rhetorical tropes and tricks in Leviathan does not by itself suggest that Hobbes reconsidered the opposition to rhetoric that he articulated in Elements and De Cive" (29). Rather, Hobbes remained hostile to what he saw as the central purpose of rhetoric - to generate controversy. For Garsten, Hobbes' uses of rhetoric in Leviathan "are best understood as an attack on the...rhetorical tradition rather than a return to it" (31). See: Bryan Garsten, Saving Persuasion: A Defense of Rhetoric and Judgment (Cambridge: Harvard University Press, 2006), 25-54.
} 
their rational capacity "by study and industry."138 He must therefore provide the tools to evoke their passions. For, as he noted in an earlier work, "not truth, but image, maketh passion.",139 And Leviathan, as we shall see, is a work suffused in imagery. This is what makes it all the more surprising and disappointing that when he attempts a theological response to the apocalyptic imaginary, Hobbes relies for the most part on dry, scriptural argument. ${ }^{140} \mathrm{He}$ fails to adequately confront apocalypticism on the battleground of the imagination.

\section{Hobbes' Secular Apocalypse}

However, Hobbes employs a second strategy in his engagement with the apocalyptic imaginary that $I$ think is at once more successful and more daring. He offers a captivating secular apocalypse in which the terror of chaos is the prerequisite for a peaceful and orderly commonwealth. As I argue below, both the specific imagery and the structural and narrative features of Hobbes' argument draw on the apocalyptic imaginary of seventeenth-century England. Hobbes' innovation was to put this antinomian imaginary to new use by redeploying it in the service of sovereign power. ${ }^{141}$

\footnotetext{
${ }^{138}$ Hobbes, Leviathan, I.3.11, 14. This marks a shift in Hobbes' political thought. In earlier works, like The Elements of Law, Hobbes treats reason as a natural human faculty. In Leviathan, he suggests that reason, unlike prudence, is acquired and artificial. For an analysis of this transition, see: Johnston, Rhetoric of Leviathan, 94-98. I discuss these views toward the end of this chapter.

${ }^{139}$ Hobbes, Elements, I.13.7.

${ }^{140}$ There are two notable exceptions - the points at which Hobbes refers, almost in the same breath, to the Roman Catholic Church as analogous to the "kingdom of fairies" and to the Papacy as "no other than the ghost of the deceased Roman empire, sitting crowned upon the grave thereof." See: Hobbes, Leviathan, IV.47.21, 482-483. However, for the most part, the theological response to the apocalyptic imaginary in the last two books of Leviathan relies heavily on Scriptural argument, rather than compelling imagery.

${ }^{141}$ While it is not possible to make any firm claims about Hobbes' intention in using the apocalyptic imagery in the way that he does, I think it is certainly plausible to suggest that his response to apocalypticism is part of a larger rhetorical strategy not "of criticism and rejection but rather of subversive reintegration." This is the argument that Franck Lessay makes about Hobbes' use of covenant theology. See: Franck Lessay, "Hobbes's Covenant Theology and Its Political Implications," in The Cambridge Companion to Hobbes's Leviathan, ed. Patricia Springborg (Cambridge: Cambridge University Press, 2007), 258. A similar argument could be made about Hobbes' idiosyncratic appropriation of the image of Leviathan, the biblical symbol of primeval chaos, as a secular symbol of political order.
} 
Philosophy begins, Hobbes argues, with "feigning the world to be annihilated." ${ }^{142}$ This imagined destruction of the world is an act of mental "privation" that allows Hobbes to construct his scientific arguments from the ground up. On the surface, this may seem like an uncomplicated example of Hobbes' devotion to the scientific method as a basis for philosophical reflection. Yet he does not leave it at that. He applies this method to his political project. He begins by drawing a comparison between states and mechanical objects. In order to understand how a watch, or a small engine, or a wheel works, "it must be taken insunder and viewed in parts." Similarly, in order "to make a more curious search into the rights of states and the duties of subjects, it is necessary not to take them insunder, but yet that they be so considered as if they were dissolved. ${ }^{143}$ Of course, Hobbes does not want to advocate the destruction of states in the name of philosophical inquiry. We must not take the state "insunder," but we should imagine that it has already been annihilated.

The political uses of this apocalyptic method become clearer in Hobbes' account of the state of nature - the condition in which men find themselves in the absence of government. Hobbes' classic description of the state of nature merits a close examination:

Whatsoever therefore is consequent to a time of war, where every man is enemy of every man, the same is consequent to the time wherein men live without other security than what their own strength and their own invention shall furnish them withal. In such condition there is no place for industry, because the fruit thereof is uncertain, and consequently, no culture of the earth, no navigation, nor use of the commodities that may be imported by sea, no commodious building, no instruments of moving and removing such things as require much force, no knowledge of the face of the earth, no account of time, no arts, no letters, no society, and which is worst of all, continued fear and danger of violent death, and the life of man, solitary, poor, nasty, brutish, and short. ${ }^{144}$

\footnotetext{
${ }^{142}$ Thomas Hobbes, The English Works of Thomas Hobbes, vol. 1, ed. Sir William Molesworth (London: Bohn, 1839), 91.

${ }^{143}$ Hobbes, De Cive, preface, 98.

${ }^{144}$ Hobbes, Leviathan, I.13.9, 76.
} 
Here, Hobbes' annihilating imagination is in full play. From a philosophical standpoint, the state of nature is the void - a condition of nothingness that will form the basis for Hobbes' construction of the Leviathan state. In a political ontology, "order had been the equivalent of being, anarchy the political synonym for non-being." ${ }^{145}$ Hobbes is describing a condition of nonexistence of the type that follows the political destruction brought about by war.

Like the threatened apocalypse that haunted his life and work, Hobbes' state of nature is a chaotic and terrifying moment in which all mankind is driven by a "perpetual and restless desire of power after power, that ceaseth only in death." ${ }^{, 146}$ It is a violent rupture in the apparent temporal continuity of history-a war in which there is "no account of time." If the Biblical apocalypse is the rupture between the saeculum and the eternity of Christ's kingdom, then Hobbes' state of nature is the rupture between the life of a political order that has dissolved and the creation of the Leviathan state. ${ }^{147}$ The state of nature is thus an imagined catastrophe that is the precondition for a new world order. In describing this state, Hobbes performs an apocalyptic "uncreation." All the markers of life in a commonwealth are called to mind only then to be annihilated-“no place for industry," "no navigation," "no commodious living," "no letters, no society." As Mark Houlahan astutely observes, "the stabbing, anaphoric clauses, all predicated from 'there is no,' mime the uncreation they describe. The effect is paradoxical...that which is described and then negated is powerfully present, only to vanish at the behest of the narrative

\footnotetext{
${ }^{145}$ Sheldon S. Wolin, Politics and Vision: Continuity and Innovation in Western Political Thought, Expanded Edition (Princeton: Princeton University Press, 2004), 218.

${ }^{146}$ Hobbes, Leviathan, I.11.2, 58.

${ }^{147}$ I tend to agree with Sheldon Wolin, who argues that "the political order was not a condition without precedent, but a prior condition once enjoyed, but then lost, and must now be recaptured." The state of nature is a "recurrent human possibility," the ever-present threat of a "relapse." See: Wolin, Politics and Vision, 236-7. This reading makes sense, I think, in light of the connections that Hobbes draws between the state of nature and the experience of civil war.
} 
voice."148 The focus of Hobbes' frightening account is the annihilation of the commonwealth, rather than the condition of natural man. The destruction of man's creations signals a kind of devastation that far exceeds mere barbarism.

Hobbes could not confine his apocalypse to the imagination. His account of uncreation had its foundation in the realities of the civil war. He makes this connection clear. In responding to the potential criticism that his description of the state of nature has no foundation in experience, Hobbes responds: "it may be perceived what manner of life there would be where there were no common power to fear, by the manner of life which men that have formerly lived under a peaceful government use to degenerate into, a civil war."149 A similar though more compelling association of the state of nature and civil war is embedded in an argument about the dangers of not taking one's own "Christian sovereign for God's prophet." Men who fail to do this, argues Hobbes, are liable to be bewitched into rebellion "and by this means destroying all laws, both divine and human, reduce all order, government, and society to the first chaos of violence and civil war." "150 Hobbes' account of the English Civil War in Behemoth echoes these frightening associations. However, perhaps the most terrifying account of war as a radical form of uncreation is in Hobbes' 1629 translation of Thucydides' History of the Peloponnesian War:

But as this war, it both lasted long, and the harm it did to Greece was such, as like in the like space had never been seen before. For neither had there been so many cities expunged and made desolate, what by the barbarians and what by the Greeks warring against one another...nor so much banishing and slaughter, some by war, some by sedition, as was in this. And those things which concerning former time there went a fame of, but in fact rarely confirmed, were now made credible: as earthquakes, general to the greatest part of the world, and most violent withal: eclipses of the sun, oftener than is reported of any former time: great droughts in some places, and thereby famine: and that which did none of the

\footnotetext{
${ }^{148}$ Mark Houlahan. "Leviathan (1651): Thomas Hobbes and Protestant Apocalypse," 1650-1850: Ideas, Aesthetics, and Inquiries in the Early Modern Era, vol. 2, ed. Kevin L. Cope (New York: AMS Press, 1996), 104-5.

${ }^{149}$ Hobbes, Leviathan, I.13.11, 77.

${ }^{150}$ Hobbes, Leviathan, III.36.19, 293.
} 
least hurt, but destroyed also its past, the plague. All these evils entered together with this war. ${ }^{151}$

Hobbes' translation gives this account of the world-annihilating catastrophe of war a vividness that is rarely matched. While one cannot attribute this imagery directly to Hobbes, I think that it is reasonable to conclude that his translation of Thucydides provided him with a vocabulary with which to both imagine and describe an apocalyptic moment of uncreation.

Yet from the ashes of the annihilated commonwealth the people create the Leviathan sovereign, an absolute authority who promises to prevent a relapse into apocalyptic chaos. There are at least two ways to understand the figure of the Leviathan in light of Hobbes' ruptural account of the state of nature. The first is to see this mythological figure as an entity capable of restraining or holding back apocalyptic violence. The second is to see the Leviathan state as the fulfillment of Hobbes' apocalypse, or the secular equivalent of the Kingdom of Christ. I will explore each of these alternatives in turn.

Following some insights first made by Carl Schmitt, some scholars have argued that Hobbes' Leviathan is a secularized katéchon - a figure that restrains the Antichrist and holds back the apocalypse. ${ }^{152}$ As we saw in Chapter 2, the Scriptural basis for the katéchon is in Paul's second letter to the Thessalonians. In his previous letter, Paul had emphasized that Christ's return to the world would be sudden and unexpected, "like a thief in the night."153 Paul's second letter suggests that the Thessalonians had mistaken suddenness for imminence and were

\footnotetext{
${ }^{151}$ Thomas Hobbes, Hobbes's Thucydides, ed. Richard Schlatter (New Brunswick: Rutgers University Press, 1975), 41. Mark Houlahan's work first directed me to see this passage in an apocalyptic context. See: Houlahan, "Hobbes and the Protestant Apocalypse," 102-3.

${ }^{152}$ Wolfgang Palaver, "Hobbes and the Katéchon: The Secularization of Sacrificial Christianity," Contagion: Journal of Violence, Mimesis and Culture 2 (1995): 57-74; Jürgen Moltmann, "Covenant or Leviathan? Political Theology for Modern Times," Scottish Journal of Theology 47 (1994): 30; Tracy B. Strong, "Forward: Carl Schmitt and Thomas Hobbes: Myth and Politics," in Carl Schmitt, The Leviathan in the State Theory of Thomas Hobbes: Meaning and Failure of a Political Symbol, trans. George Schwab and Erna Hilfstein (Chicago: University of Chicago Press, 2008), xxiii-xxvi.

153 1 Thess. 5:2.
} 
expecting Christ's return at any moment, leading to some disorder in the community. Paul assures them that the final days are not at hand. Christ's return will be preceded by events that have not yet happened. Jesus will come only after there had been a "falling away" during which the "lawless one" will reveal himself by sitting in the temple of God and "declaring himself to be God."154 Yet, as Paul writes, the "lawless one" remains restrained: "And you know what is now restraining him, so that he may be revealed when his time comes."155 Paul continues: "The mystery of lawlessness is already at work, but only until the one who now restrains it is removed. And then the lawless one will be revealed, whom the Lord Jesus will destroy with the breath of his mouth, annihilating him by the manifestation of his coming." "156 The Greek word for the "one who restrains" is katéchon, or restrainer. If we take the "man of sin" to be Antichrist, then the katéchon is the force restraining Antichrist and, by extension, the arrival of the apocalypse. For, the apocalypse cannot arrive until the Antichrist is loosed.

Historically, the restrainer has often been identified with sovereign and imperial power. For instance, Christian theologians Hippolytus (170-263) and Tertullian (160-220) identify the katéchon with the Roman Empire. The identification of sovereign power with the mysterious restrainer appealed to Schmitt, who sympathized with what he took to be Hobbes' attempt to restrain the apocalyptic promise and antinomian danger of Christian belief. For Schmitt, the Leviathan sovereign performs the same function as Paul's mysterious "restrainer." In a rather idiosyncratic comparison, Schmitt likens the Hobbesian sovereign to Dostoevsky's Grand Inquisitor, who arrests the returned Jesus for threatening the order and stability that has been achieved by offering men happiness in exchange for their freedom. Both the Leviathan and the

\footnotetext{
${ }^{154} 2$ Thess. $2: 3-8$.

1552 Thess. 2:6.

${ }^{156} 2$ Thessalonians 2:7-8. I've used the American Standard Version for this passage.
} 
Grand Inquisitor seek to prevent the radical disorder that would come with the Second Coming of Jesus without doing away with Christianity altogether. Thus, for Schmitt:

Hobbes articulated and provided scientific reason for what the Grand Inquisitor did: to make the effect of Christ harmless in the social and political sphere; to deanarchize Christianity but to leave it at the same time some kind of legitimating effect in the background and in any case not to do without it. A clever tactician gives up nothing, at least as long as it is not totally useless. Christianity was not yet spent. Therefore, we may ask ourselves: who is closer to Dostoevsky's Grand Inquisitor: the Roman Church or Thomas Hobbes's sovereign? ${ }^{157}$

The sovereign does not merely restrain the forces of chaos, but holds back the arrival of Christ on earth. ${ }^{158}$ The radical apocalyptic imaginary is an anarchic and destabilizing force that must be kept in check by sovereign power. It if were to be let loose, we would experience a reversion to primordial chaos.

As we have seen in the foregoing analysis, Hobbes certainly offers some support for this interpretation, particularly if we accept the connections between anarchy, civil war, and the apocalypse. For Hobbes, the civil war was anarchic because of the proliferation of private interpretation and judgment. Private judgments about the nature of justice and injustice, good and evil proliferated. In the state of nature, "nothing can be unjust. The notions of right and wrong, justice and injustice, have there no place. Where there is no common power, there is no law; where there is no law, no injustice. Force and fraud are the cardinal virtues."159 The sovereign puts an end to this ethical and linguistic anarchy by stabilizing values and language through positive law. Similarly, Hobbes locates the roots of England's civil war in a proliferation of private interpretations of Scripture made possible by the translation of the Bible

\footnotetext{
${ }^{157}$ Carl Schmitt, Glossarium. Aufzeichnungen der Jahre 1947-1951, as quoted and translated in Palaver, "Hobbes and the Katéchon," 67-8.

${ }_{158}$ Palaver, "Hobbes and the Katéchon," 68.

${ }^{159}$ Hobbes, Leviathan, I.13.13, 78.
} 
into the vernacular. ${ }^{160}$ Now the potentially radical and anarchic message of Christ was available for interpretation by anyone. In response to this threat, Hobbes invests in his Leviathan the sole authority for the interpretation of Scripture. Finally, it is clear that Hobbes sees a dangerous anarchic potential in claims to prophetic inspiration. This problem has become so acute, he explains, "that the number of apostates from natural reason is almost become infinite." $\mathrm{He}$ continues by arguing that the opinion that faith is acquired through inspiration "sprang from sickbrained men, who having gotten good store of holy words by frequent reading of the Scriptures, made such a connexion of them usually in their preaching, that their sermons, signifying just nothing, yet to unlearned men seemed most divine. For he whose nonsense appears to be a divine speech, must necessarily seem to be inspired from above." ${ }^{\prime 61}$ In order to thwart the potentially dangerous effects of such "nonsense," Hobbes demands that we accept our sovereign as our only prophet. ${ }^{162}$ In all of these ways, Hobbes' sovereign moves to restrain the anarchic and antinomian features of Christianity.

However, while I think this Schmittian account offers a compelling reading of the political and theological characteristics of Hobbes' sovereign, it misses the way in which the Leviathan must participate in a secular apocalypse in order to hold back its Christian counterpart. In so doing, the sovereign becomes not just the mortal God, but also the mortal Christ, establishing a secular kingdom on earth. Because it is so focused on the anarchic and dangerous character of the state of nature, the Schmittian reading fails to recognize how the apocalyptic violence of civil war provides the preconditions for Hobbes' secular millennial kingdom. For, as terrifying as the state of nature or civil war is, it offers the opportunity for an

\footnotetext{
${ }^{160}$ Hobbes, Behemoth, I, 21-2.

${ }^{161}$ Hobbes, De Cive, 12.6, 249.

${ }^{162}$ Hobbes, Leviathan, III.36.19, 293.
} 
act of profound political creativity - the construction of an enduring commonwealth from the fear and emptiness of apocalyptic anarchy.

We can grasp how Hobbes' Leviathan state can be seen as a secularized millennial kingdom by comparing his accounts of civil sovereignty and the Kingdom of Christ. Before embarking on the comparison, however, it is worth noting some important differences between Hobbes' secular and sacred kingdoms. Hobbes' sovereign is forced to deal with men as they are, rather than men "as they should be." 163 Those ruled by Hobbes' Leviathan are fearful, acquisitive, and sinful, while those in Christ's millennial kingdom have been saved and are secure from sin. Thus, while the secular state is governed by enforceable laws, Christ's kingdom has no need for law. ${ }^{164}$ Nevertheless, there are striking similarities between Hobbes' accounts of the secular and sacred kingdoms. For instance, both have a single locus of authority. In the millennial kingdom, Christ rules both in his spiritual and political capacities. Hobbes is clear that Christ's kingdom, like the Jewish Kingdom of God that existed before it, will be a civil kingdom on earth. ${ }^{165}$ The first Kingdom of God was created by a covenant between the people of Israel and God, was "cast off in the election of Saul," and will be restored by Christ at the Day of Judgment. ${ }^{166}$ Sovereignty in both the secular and sacred kingdoms is unified and not participatory. In the secular kingdom, the sovereign acts as the sole judge and author of laws. ${ }^{167}$ Similarly, Christ acts as the sole judge in his sacred kingdom, passing judgment on all of

\footnotetext{
${ }^{163}$ Hobbes makes this distinction in his assessment of why the Jewish Kingdom of God was unsuccessful. "For there God reigns indeed, where his laws are obeyed not for fear of men, but for fear of himself. And truly, if men were such as they should be, this were an excellent state of civil government; but as men are, there is a coercive power (in which I comprehend both right and might) necessary to rule them." See: Hobbes, De Cive, 16.15, 323. I draw my analysis in these two paragraphs largely from Joel Schwartz, "Hobbes and the Two Kingdoms of God," Polity 18, no. 1 (1985): 7-24.

${ }^{164}$ Hobbes, De Cive, 17.8, 340.

${ }^{165}$ Hobbes, Leviathan, III.35.

${ }^{166}$ Hobbes, Leviathan, III.35.13, 276.

${ }^{167}$ Hobbes, Leviathan, II.18.6, 112.
} 
humanity in a ritual that fuses absolute grace and absolute power. He "shall judge the world, and conquer his adversaries, and make a spiritual commonwealth." 168

Perhaps most importantly, both the secular and sacred sovereigns carry out a fundamental transformation of humanity. Christ grants immortality to the faithful by transforming their natural and mortal bodies into spiritual and immortal bodies. ${ }^{169}$ For Hobbes, this transformation from mortal to immortal bodies is the essence of salvation. He reasons: "because man was created in a condition immortal, not subject to corruption... and fell from that happiness by the sin of Adam, it followeth that to be saved from sin is to be saved from all the evil and calamities that $\sin$ hath brought upon us. And therefore, in the Holy Scripture remission of sin, and salvation from death and misery, is the same thing." ${ }^{170}$ Through the sin of Adam humanity lost its immortality. The act of salvation and redemption is therefore the restoration of immortality to the saved. While the Leviathan state cannot save men from eventual death or redemption from $\sin$, the provision and enforcement of laws by the sovereign go some way in protecting them from the senseless and premature deaths that occur in the absence of civil authority. The state of nature is fraught with dangers. Christ cannot offer any kind of redemption or salvation here and now because he will not be an earthly sovereign until he comes again. Thus, in the saeculum, the sovereign is the only redeemer. He can save men from possible death in this life, offering a temporary salvation. The value of this worldly salvation should not be underestimated. As A.P. Martinich explains, 'since 'life' and 'death' are meant literally when Hobbes applies them in both his political and religious discussions, salvation here and now is every bit as precious to humans as salvation at the Second Coming will be then."171

\footnotetext{
${ }^{168}$ Hobbes, Leviathan, III.42.128, 394.

${ }^{169}$ Hobbes, Leviathan, III.42.128, 394.

${ }^{170}$ Hobbes, Leviathan, III.38.15, 310.

${ }^{171}$ Martinich, Two Gods of Leviathan, 272.
} 
Perhaps most impressively, the Leviathan is able to draw on man's anxiety about the future to transform rebellious and anarchic beings into obedient subjects. ${ }^{172}$ These subjects reduce their wills "unto one will," that of a mortal God who through sheer terror "is enabled to conform the wills of them all to peace." Leviathan, Hobbes was not at all confident that one could rely on men's rational capacities and their natural fear of death to lead them toward peace. In earlier works like The Elements of Law, Hobbes had treated reason as a natural human faculty. However, in Leviathan he suggests that reason is acquired and artificial. Beyond prudence, there is "no other act of man's mind...naturally planted in him so as to need no other thing to the exercise of it but to be born a man." Other faculties, like reason, must be "acquired and increased by study and industry."174 One cannot then rely on reason to incline men toward peace and the acceptance of an absolute sovereign. Similarly, as I discussed earlier in the chapter, Hobbes is not entirely confident that the fear of death can be relied upon for this purpose either. While he seems to want to suggest that the fear of death is our most basic and reliable fear, he worries that "the fear of darkness and ghosts is greater than other fears." ${ }^{175}$ In order to produce a lasting secular peace, the sovereign, as a mortal God, must therefore terrify man and hold him in awe. Through his power over both secular punishments and Scriptural interpretation, he must turn his subjects into the kinds of men that imagine no rewards greater than life and no punishments worse than death. In short, he must turn them into the kind of men who could rationally accept an absolute sovereign. ${ }^{176}$ This is a

\footnotetext{
172 Schwartz, "Two Kingdoms of God," 21-23.

${ }^{173}$ Hobbes, Leviathan, II.17.13, 109.

${ }^{174}$ Hobbes, Leviathan, I.3.11, 14.

${ }^{175}$ Hobbes, Leviathan, II.29.15, 216.

${ }^{176}$ There is an authorization problem here. According to Hobbes' account of the origins of sovereign power, men consent to an absolute sovereign because as rational beings who are fearful of death they see it as the only way to avoid the violence of the state of nature. However, at numerous points in Leviathan, Hobbes seems to suggest that we are not naturally rational and that some of us may have fears greater than death. It is only through learning and a correct interpretation of Scripture, which remove the possibility of fears greater than death, that we can be made into
} 
transformation of theological proportions. ${ }^{177}$ Hobbes even holds out the possibility that there may be a way to make this secular kingdom, like the Kingdom of Christ, "everlasting."178 Thus, while Hobbes' state, as katéchon, may indeed hold back the anarchic potential of the Christian apocalypse, it can only do so by first participating in a secular apocalypse of its own.

The analogy between Hobbes' account of Christ's kingdom and that of the secular state extends beyond the text of Leviathan. In an admittedly speculative move, I would like to suggest that there are distinctively Christic features in the Leviathan represented in Hobbes' famous frontispiece (see figure 6). ${ }^{179}$ The picture depicts a large figure wearing a crown, holding a sword in his right hand and a crosier in his left. These items are not placed in opposition to one

the kinds of beings capable of consenting to a sovereign. Yet, for Hobbes, neither this kind of learning nor the imposition of a particular Scriptural interpretation can occur in the absence of the peace guaranteed by a sovereign. Thus, in order to consent to a sovereign, we would have to already be the subjects of a sovereign. Whether or not this poses a fundamental problem for Hobbes' social contract theory depends on one's assessment of the importance the theorist places on consent. My sense is that consent is not as important to Hobbes as it is to other social contract theorists, like John Locke and Jean-Jacques Rousseau.

${ }^{177}$ David Johnston argues that Hobbes' "recognition of the pervasiveness of ignorance and the power of superstitious beliefs" did not lead Hobbes to argue that sovereign power must rest on myths, beliefs, and illusions. As Johnston explains, "Hobbes did not argue that the real power of a sovereign over the lives (and deaths) of his subjects should be supplemented by the kind of awe that derives from belief in the supernatural." See: Johnston, Rhetoric of Leviathan, 110-111. I think Johnston is right. Hobbes does not make this argument. However, as a student of Hobbes' rhetoric, it is surprising that Johnston does not consider that this may be something that Hobbes does not have to argue. The metaphors and images associated with the sovereign-the "Mortal God," the Leviathan - as well as the fabulously evocative frontispiece to the work may make this point in ways that exceed the possibilities of any kind of argument.

${ }^{178}$ Hobbes, Leviathan, II.30.5, 221.

${ }^{179}$ There are two frontispieces of Leviathan - the more familiar engraved image in the 1651 printed edition of the work and the hand-drawn image in the manuscript copy. Vaughan summarizes the differences between the two as follows: "In the printed version the people making up the body of Leviathan are shown almost in full and all have their eyes fixed upon the face of the mortal god. In the penned version the body of Leviathan is made of faces looking out in the same direction as the head. There are also some differences in the face of Leviathan between the two copies... and a quotation from Job is inserted into the printed version. Some minor discrepancies exist within the landscapes and among the buildings of the city in the foreground. The general impression however, is very much the same." See: Vaughan, "Audience of Leviathan," 466. Despite the similarity in the "general impression," it is worth emphasizing the importance of the orientations of the people who make up the Leviathan's body. Keith Brown, who has offered one of the most detailed analyses of the frontispiece image, suggests that the manuscript version in which the people are looking outwards seems "much better to express the more traditional view...that in his book Hobbes is trying to get as close as possible to asserting that what is done by the sovereign in his official capacity is, quite literally, also done by his subjects." See: Keith Brown, "Thomas Hobbes and the Title-page of Leviathan," Philosophy 55, no. 213 (1980): 411. See also: Keith Brown, "The artist of the Leviathan title-page," British Library Journal 4, no. 1 (1978): 24-36. Given that the manuscript frontispiece predates the 1651 printed frontispiece, Brown and others argue that the earlier version of the image was likely the one over which Hobbes himself had the most input. 


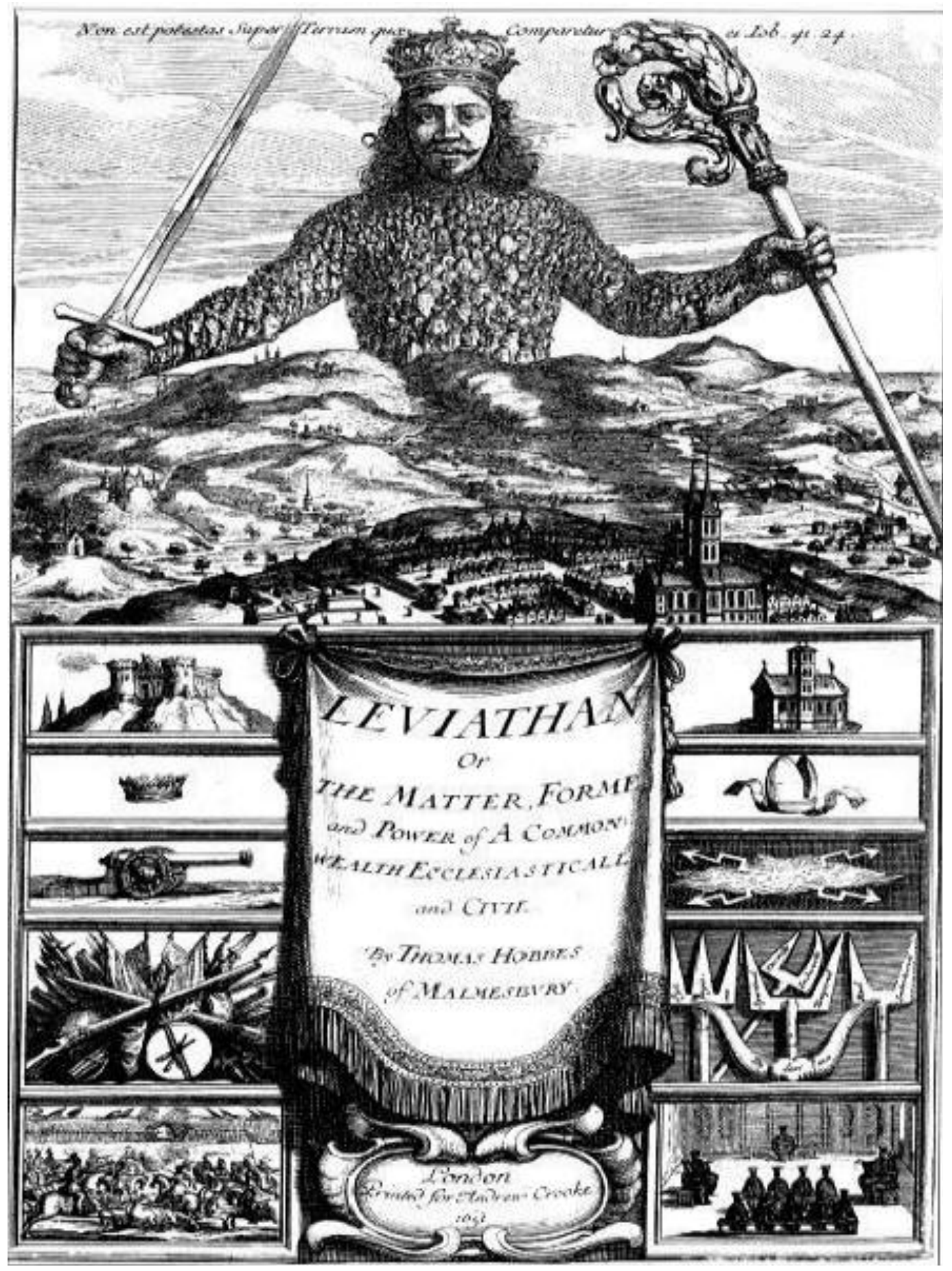

Figure 6: Frontispiece of Leviathan, 'Head' edition, 1651. 
another, "but are pointed in such a way that they would converge above Leviathan's head if they were extended." ${ }^{, 180}$ His body consists of numerous smaller people. In the engraved frontispiece that accompanies the 1651 printed edition of Leviathan, these people are all looking toward the head of the mortal god. The figure dominates a landscape dotted with fortresses, churches, and orderly rows of houses. While the picture draws the eye upward toward the Leviathan, there are some detailed illustrations in the lower half of the image. Opposite panels lie under the sword and the crosier, offering visual representations of secular and religious authority. Looking from left to right and top to bottom, the images are: a castle and a church; a crown and a miter; a cannon and a thundercloud; the weapons of war and the "weapons of intellectual disputation, as it is practiced in the clergy-dominated universities" ${ }^{\prime 181}$; and a battle and a curial assembly. ${ }^{182}$ While scholars disagree about the degree to which Hobbes himself had input into the image, most acknowledge that the frontispiece conveys the general thrust of his argument and especially to the fusion of secular and religious authority in the person of the sovereign. The most pronounced disagreements concern the question of whose face that of the Leviathan might be modeled upon. Scholars have guessed that the face is meant to resemble that of Charles I, Oliver Cromwell, Charles II, or even Hobbes himself. ${ }^{183}$

Yet, given that the image represents the fusion of secular and religious authority, is it not also possible that the figure has the bearing and manner of Christ? As A.P. Martinich suggests, "the size of Leviathan is consonant with a divine figure. His two outstretched arms indicate both divine, or quasi-divine, judicial judgment and universal jurisdiction." Furthermore, the

\footnotetext{
${ }^{180}$ Martinich, Two Gods of Leviathan," 363.

${ }^{181}$ Martinich, Two Gods of Leviathan, 366.

${ }^{182}$ Martinich, Two Gods of Leviathan, 364-6; Vaughan, “Audience of Leviathan, 466.

${ }^{183}$ For reviews and evaluations of these possibilities, see: Martinich, Two Gods of Leviathan, 362-363; Vaughan, "Audience of Leviathan," 467-9; M.M. Goldsmith, "Hobbes's Ambiguous Politics," History of Political Thought 11 , no. 4 (1990): 654-73.
} 
Leviathan is in a pose that is similar to that of Christ in many Renaissance paintings. ${ }^{184}$ Martinich does not pursue this line of visual association, but one may do so in at least a tentative manner by examining a selection of works by Anthony Van Dyck, England's leading court painter during the reign of Charles I. Van Dyck painted numerous portraits of Charles I (see figures 7 and 8 for two prominent examples), many of them in which the king is shown either wielding or wearing the symbols of secular power. In none of these paintings is England's sovereign shown with his arms open, in the manner of Leviathan. One hand is often on the king's hip, while the other holds a sword or rests elegantly at his side. In fact, it is difficult to find any Renaissance image of a sovereign with his arms open. Yet this open-armed pose had been a standard one for images of a judging or healing Christ since the medieval period. Van Dyck's own Christ Healing the Paralytic (see figure 9) offers a typical Renaissance example of the open-armed pose. However, Gislebertus' medieval Last Judgment (see Figure 10) provides the most striking visual comparison with Hobbes' frontispiece. Like Leviathan, Christ is portrayed here as a giant towering over his subjects. ${ }^{185}$ The text carved into lintel could just as easily be applied to the secular reign of the Leviathan sovereign: "That here the horror terrifies horror, those bonded to earthly error."186

\footnotetext{
${ }^{184}$ Martinich, Two Gods of Leviathan, 363.

${ }^{185}$ Horst Bredekamp is, to my knowledge, the first scholar to make the visual association between Hobbes' frontispiece and this image of Christ. See: Hors Bredekamp, "Thomas Hobbes's Visual Strategies," in The Cambridge Companion to Hobbes's Leviathan, ed. Patricia Springborg (Cambridge: Cambridge University Press, 2007), 50 .

${ }^{186}$ As translated in Bredekamp, "Hobbes’s Visual Strategies," 51.
} 


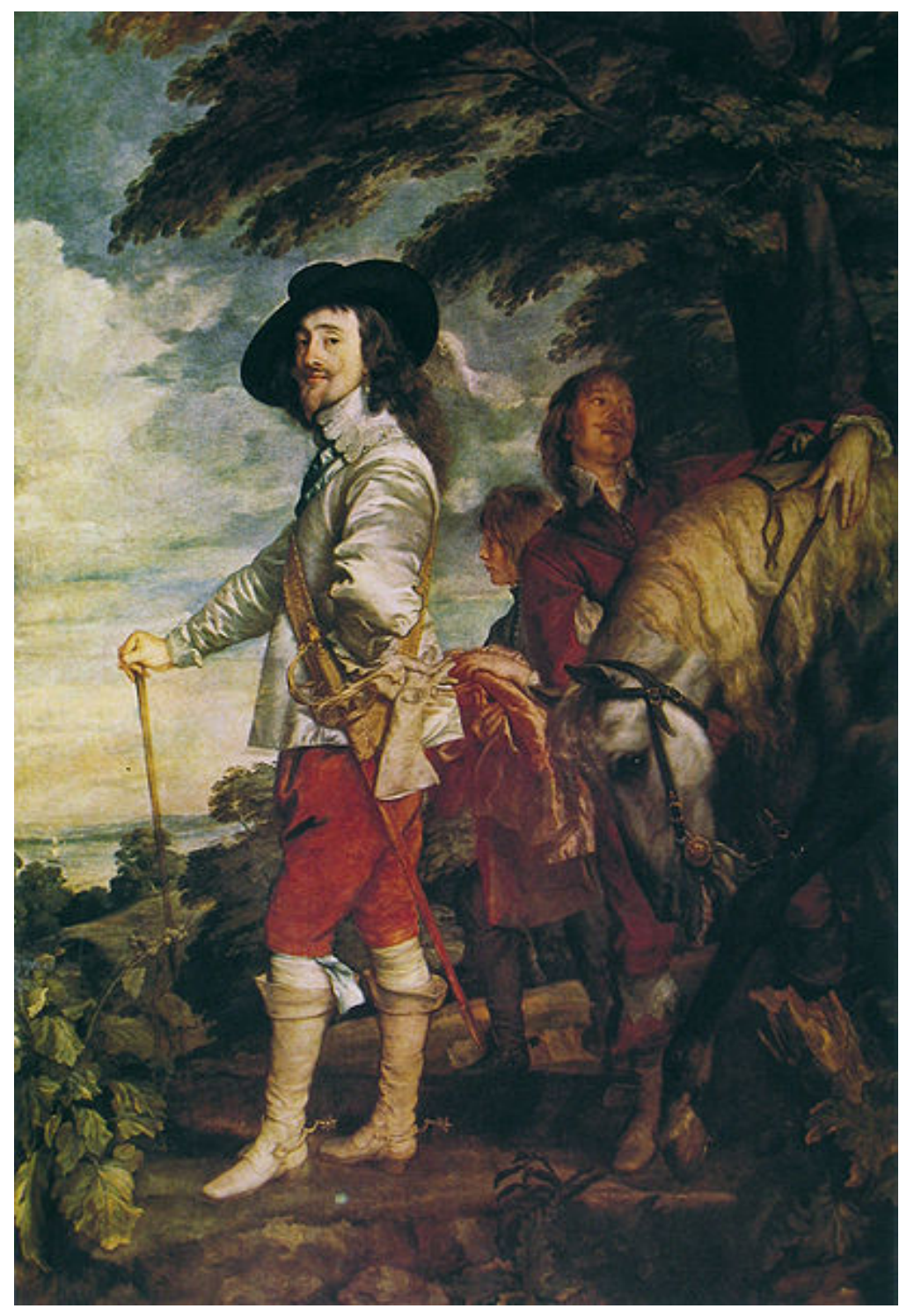

Figure 7: Anthony Van Dyck, King Charles I, ca. 1635. Musée du Louvre, Paris. 


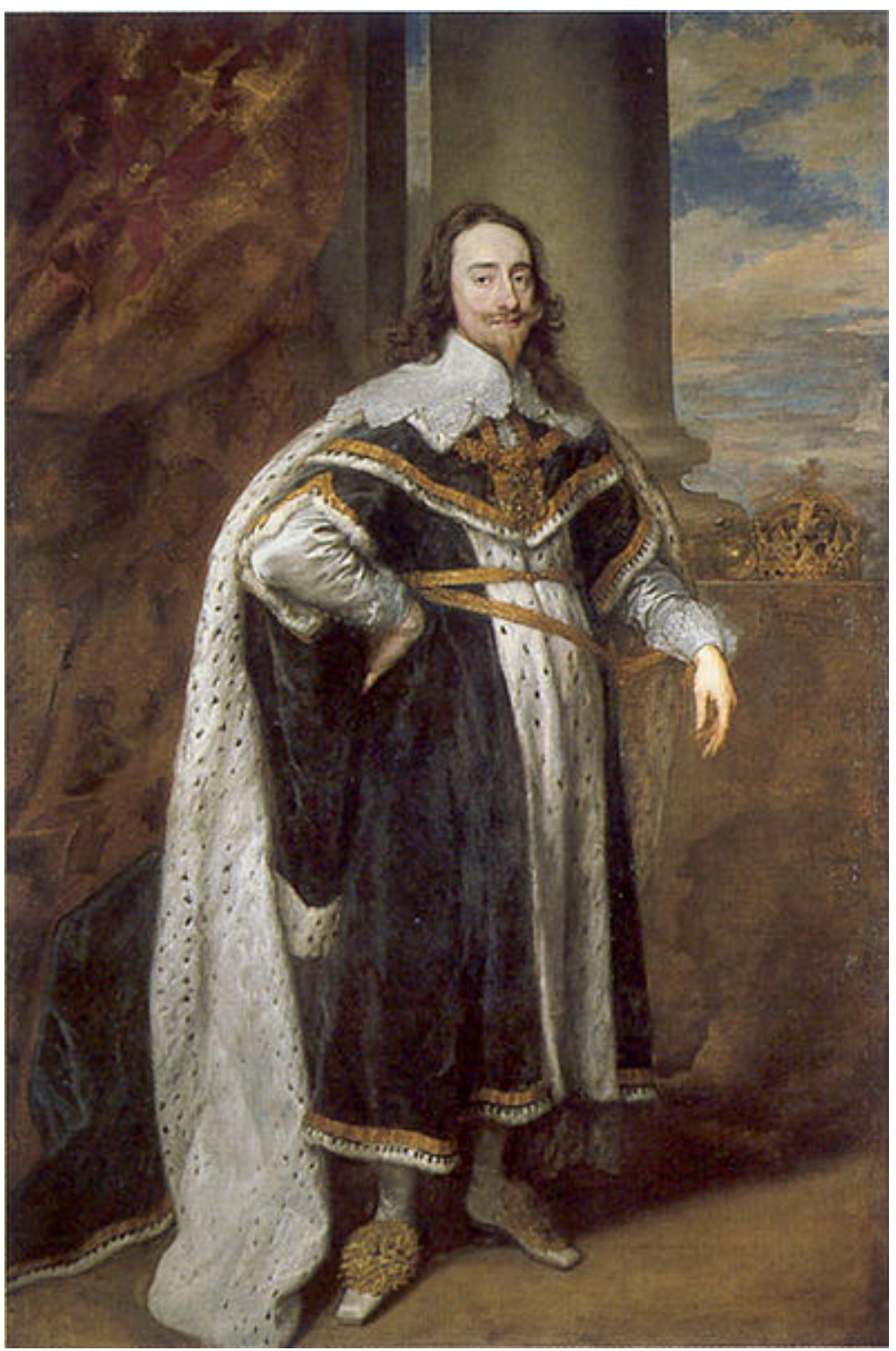

Figure 8: Anthony Van Dyck, Charles I, King of England, 1636. Windsor Castle, Windsor. 


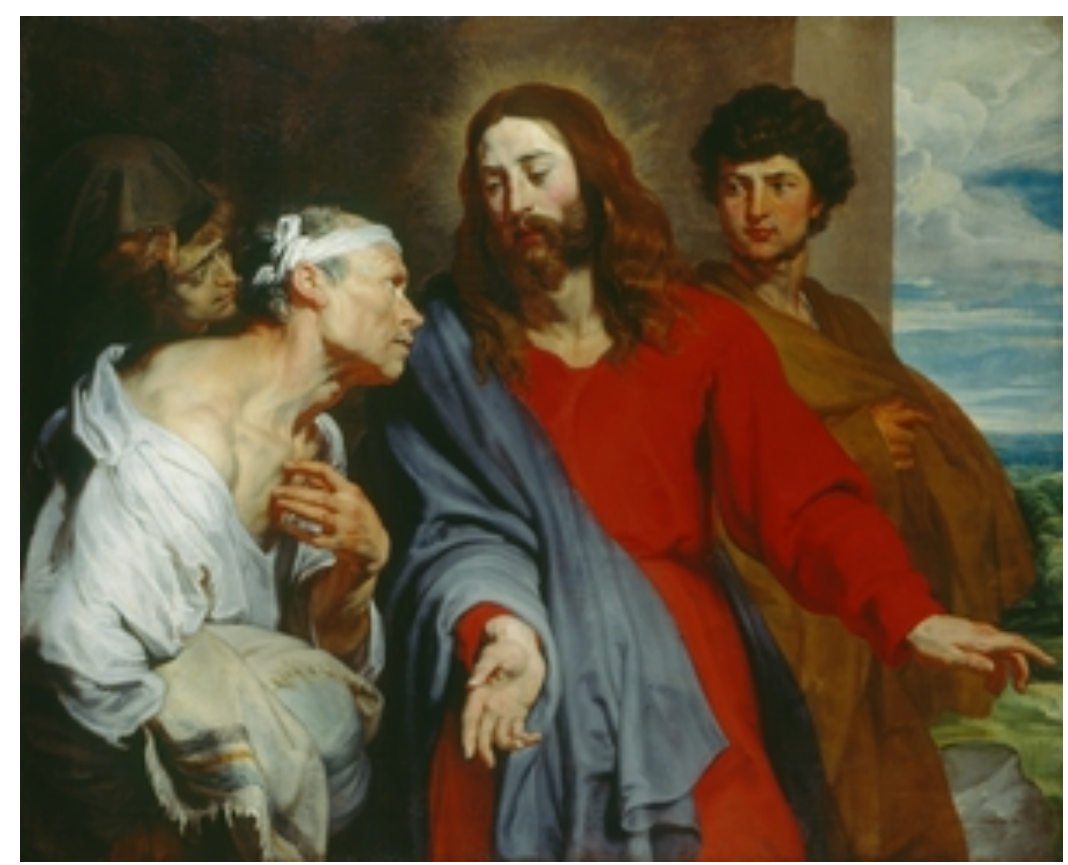

Figure 9: Anthony Van Dyck, Christ Healing the Paralytic, 1619. British Royal Collection. 


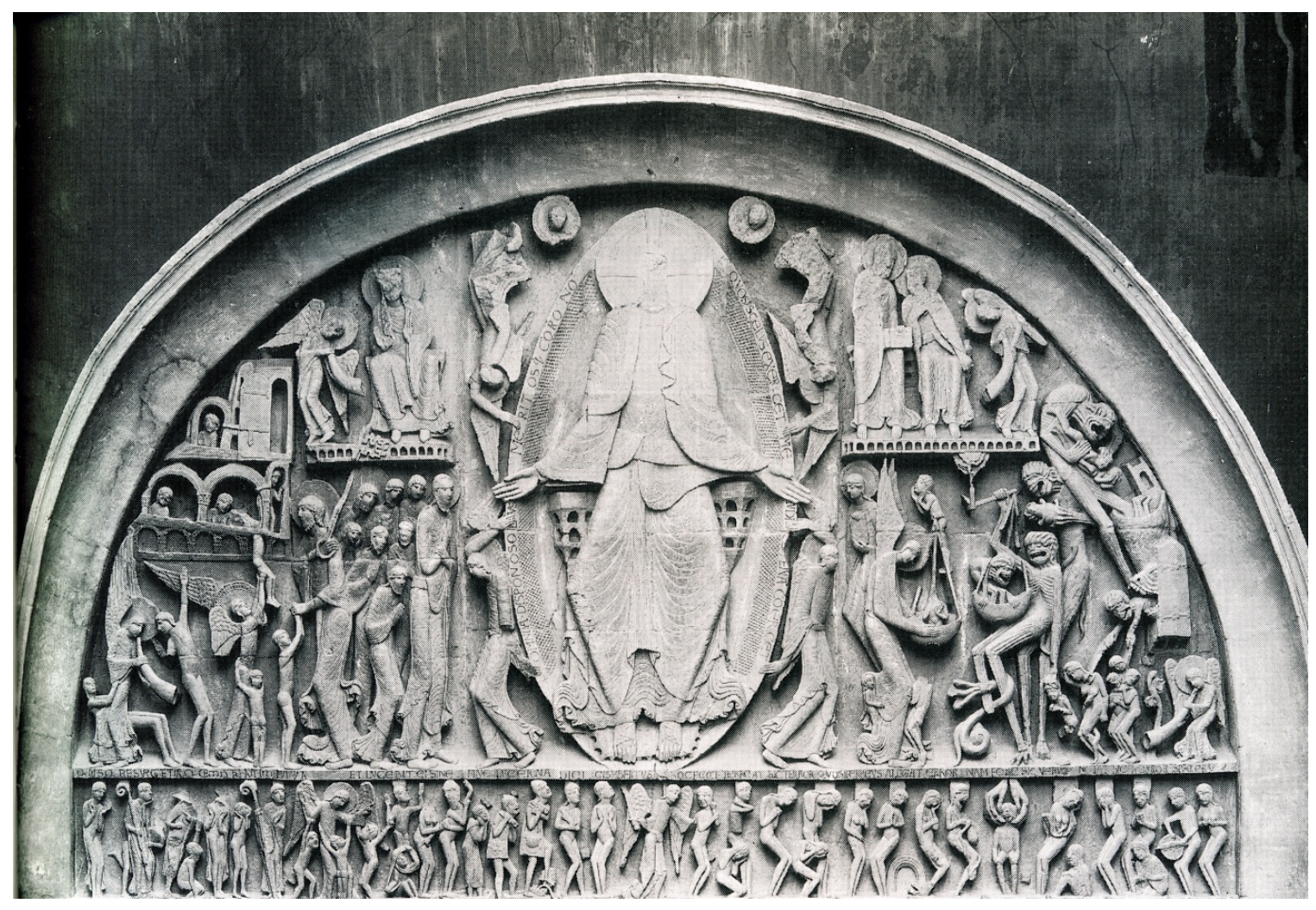

Figure 10: Gislebertus, The Last Judgment, 1130-1135. Autun Cathedral, Autun. 
My suggestion here is not that the image of Leviathan is meant to be a clear representation of Christ, but rather that the figure partakes of both the secular and the Christic. It is clear that Hobbes himself thought that his own sovereign, Charles I, was a Christ-like figure:

For in a discourse of our present civil war, what could seem more impertinent than to ask (as one did) what was the value of a Roman penny? Yet the coherence to me was manifest enough. For the thought of the war introduced the thought of delivering up the king to his enemies; the thought of that brought in the thought of the delivering up of Christ; and that again the thought of the 30 pence which was the price of that treason. ${ }^{187}$

And, as we have seen, there are close connections for Hobbes between the secular kingdom and the kingdom of Christ - both emerge from apocalyptic terror and violence and both begin with a fundamental transformation of humanity. The figure that looms over the landscape of the frontispiece will, like Christ, preside over a kingdom of peace on this earth.

\section{Conclusion}

In this chapter, I have argued that Hobbes, like Machiavelli, developed his political thought in an environment marked by widespread fears and hopes about the end of the world. Unlike Machiavelli, Hobbes does not turn away from the apocalyptic imaginary and embrace a tragic sensibility. Rather, he fights apocalypse with apocalypse. In his theological argument, he offers a de-radicalized Christian eschatology aimed at returning the apocalypse safely into sovereign hands. I argue that his efforts here are less successful because he fails to engage the apocalypse as an imaginary. However, Hobbes' political argument relies on a secularized rendering of the themes from the apocalypse that engages the imagination with rich visual and rhetorical strategies. In short, in his political argument, Hobbes is able to confront the apocalypse on the battleground of the imagination. The account I have offered here therefore

\footnotetext{
${ }^{187}$ Hobbes, Leviathan, I.3.3, 12.
} 
differs from those who read his political argument ahistorically as merely an abstract account of the normative foundations of sovereignty. Such a reading fails to account for the ways in which Hobbes' argument relies not only on the persuasive force of a logical thought experiment but also on the power of apocalyptic narratives and imagery to provoke belief.

This reading of Hobbes has several implications for his identification as a political realist. First, as is the case with Machiavelli, Hobbes' realism is deeply contextual. Leviathan is often taken to be Hobbes' most politically realist work. Its pessimistic account of human nature, its commitment to a scientific approach to understanding the political world as it is, and its attention to the importance of power all seem to support this classification. It is important, however, that this work only develops in response to a civil war rife with apocalypticism. Only by considering this context can we understand why half of Leviathan is devoted to the assessment of theological arguments. This engagement with theology suggests that Hobbes is a more interesting and complex realist than caricatures of him suggest. He recognizes that power has both material and ideational, or in this case theological, foundations. For the project of a peaceful political order to succeed, one must engage both the struggle for material power and the battle over "powers invisible."

Second, the analysis in this chapter suggests that there is a powerful normative core at the root of Hobbes' realism. His pessimistic account of man as self-interested, egoistic, and fearful of death is seriously challenged by the hold that the apocalyptic imaginary and other "powers invisible" held over the minds of many of Hobbes' contemporaries. At numerous points in Leviathan, Hobbes worries that the influence of prophets and preachers may engender a belief in rewards greater than life and punishments worse than death. The task of Leviathan, then, is not to describe men as they are but to offer a vision of what they should be and a strategy for their 
transformation. For it is only egoistic, self-interested men who fear death who will consent to an absolute sovereign promising worldly peace. Thus, contrary to conventional readings of his argument, Hobbes does not assume the existence of egoistic, self-interested men. He aims to create them. ${ }^{188}$

Finally, Hobbes' engagement with the apocalyptic imaginary suggests that there may be a rhetorically pragmatic character to his realism. He recognizes that the apocalyptic imaginary captivates people, often holding them back from being the kinds of egoistic, self-interested beings that can be made to accept a sovereign. Instead of rejecting the apocalyptic imaginary, as Machiavelli does, Hobbes redeploys it. In fighting apocalypse with apocalypse, he uses the ideational tools of his enemies against them. Both the imagery and the narrative structure of his secular political argument appropriate elements of the seventeenth-century English apocalyptic imaginary. Understood in this way, the political argument of Leviathan is not merely an abstract account of the normative basis of sovereign power meant to persuade through careful reasoning. It is also an attempt to subvert the apocalyptic imaginary from within by appropriating its imagery and narrative structure to provoke belief in a secular sovereign. Yet there are important questions about the degree to which this strategy could be effective in combating the apocalyptic imaginary. After all, the experience of Hobbes' own time suggests that the apocalyptic imaginary consistently escapes efforts at sovereign control. More importantly for the development of Hobbes' thought, his redeployment of the apocalyptic imaginary coincides with this most pronounced abandonment of the realist commitment to take man as one finds him. Instead, Hobbes offers the utopian promise that humanity may be transformed through an encounter with a monstrous Leviathan sovereign capable of eliciting the kinds of fears required

\footnotetext{
${ }^{188}$ Michael Williams puts the point similarly (though to somewhat different ends) in: The Realist Tradition and the Limits of International Relations (Cambridge: Cambridge University Press, 2005), 14.
} 
for an enduring earthly peace. In fighting the apocalypse with apocalypse, Hobbes succumbs to one of its most radical hopes. In the next chapter, I will argue that Hans Morgenthau's later work betrays a similar abandonment of realist principles. 


\section{CHAPTER FIVE}

\section{HANS MORGENTHAU AND THE POSTWAR APOCALYPTIC IMAGINARY}

The previous two chapters traced the responses of Niccolò Machiavelli and Thomas Hobbes to outbreaks of apocalypticism in their respective times. I argued that while Machiavelli is initially captivated by the apocalyptic imaginary, he later turns away from it and adopts instead a robustly tragic sensibility. Hobbes takes an entirely different approach. Rather than turning away from the apocalyptic imaginary, he redeploys it in the service of sovereign power. He fights apocalypse with apocalypse. In this chapter, I will argue that Hans Morgenthau does both.

Writing in the shadow of the Nazis, the Holocaust, and the atomic bomb, Morgenthau's political realism was shaped by a context that initially seems radically different than the Christian apocalyptic movements to which Machiavelli and Hobbes were responding. However, using the political theological approach outlined in Chapter 1, I will argue that the way in which these events were imagined is at crucial points analogous to the religious apocalyptic beliefs of the Italian Renaissance and the English Civil War. From the Nazi belief in a millennial Reich to the redemptive hopes that nuclear war could usher in a new world of peace and prosperity, the Judeo-Christian apocalypse insinuated itself into the seemingly secular ideas and images of the twentieth century. Morgenthau's postwar work is centrally concerned with the dangers of this secular apocalyptic imaginary. From the late 1940s to the early 1960 s, his work takes aim at the eschatological hopes of contemporary political religions. While the memory of Nazism looms large during this period, Morgenthau's primary target is liberal internationalism. In its most aggressive form, this secular religion sees a decisive battle against the forces of tyranny as the necessary prerequisite for a permanent democratic peace. Morgenthau's response to the liberal apocalyptic imaginary is a turn to tragedy. Like Machiavelli, he opposes the apocalyptic longing 
for the violent birth of a new world with a tragic insistence on the inescapable and undecided struggle of politics. However, in the early 1960s, in the shadow of the terrifying prospect of thermonuclear war, Morgenthau turns away from tragedy and adopts the Hobbesian strategy of fighting apocalypse with apocalypse. Against dangerously optimistic scenarios of nuclear war, he offers a terrifying account of an apocalypse without worldly redemption. Faced with the novel threat of nuclear annihilation, he seems to conclude that tragedy is not enough. We must constantly imagine the apocalypse in order to prevent it.

This chapter proceeds in three parts. First, I sketch the contours of the postwar apocalyptic imaginary, with a particular focus on the ways in which elements of the JudeoChristian apocalypse were secularized in the narratives and images of Nazism, the Holocaust, and nuclear era. Second, I outline Morgenthau's critique of the apocalyptic longings of liberal internationalism and the dangers that he diagnoses in a postwar world dominated by crusading political religions with the means to wage total war. I then trace his turn to tragedy as a counterapocalyptic worldview. Third, I argue that Morgenthau eventually finds this tragic worldview inadequate for confronting the novel dangers of a nuclear world. Instead, he strategically redeploys the apocalyptic imaginary to cultivate the existential fear required to prevent nuclear annihilation.

\section{'For Us, Time Stopped': The Postwar Apocalyptic Imaginary}

On January 8, 1918, ten months before the end of World War I, Woodrow Wilson made an eschatological promise to Americans and the world. This war would be the "final and culminating war for human liberty." He had already told Americans that they would be put to

\footnotetext{
${ }^{1}$ Woodrow Wilson, Address to Joint Session of Congress (January 8, 1918), accessed February 25, 2011, http://wwi.lib.byu.edu/index.php/President_Wilson's_Fourteen_Points
} 
the test in a battle to make "the world safe for democracy." A new world would be born not of slow and progressive change, but of "fiery trial and sacrifice" in "the most terrible and disastrous of all wars"- a war for "civilization itself.", In imagining the Great War in these terms, Wilson cast it as a violent rupture in the temporal continuity of history, the terrible prerequisite for a new world order. Given the staggering number of casualties and the horrifying realities of trench warfare and poison gas, this apocalyptic narrative might have comforted those looking for some purpose and promise in a war that seemed absurd.

Yet, even before the memories of gangrene, gas clouds, and corpses rotting in "no man's land" could fade, the world was witnessing a second war, and one that would fundamentally transform the twentieth-century apocalyptic imaginary. The numbers alone seem to take on apocalyptic proportions: over 60 million total deaths, including six million European Jews and millions of others killed in the Nazi genocide and final death tolls of 135,000 and 50,000 in Hiroshima and Nagasaki, respectively. Yet it is the images, rather than the numbers, that would come to dominate collective visions of the end times-Hitler's rallies, the mass graves at Auschwitz, and the atomic bomb clouds over Hiroshima and Nagasaki. As a German Jew who left his country in 1932 and emigrated to the United States in time to witness the birth of a nuclear age, Morgenthau struggled to envision the prospects for order and survival in a world in which the apocalypse loomed not only as an imminent future but also as an experience that had been lived in the concentration camps and the burning remains of annihilated cities. In this section of the chapter, I focus on the apocalyptic dimensions of Nazism, the mass exterminations of the Holocaust, and the development and deployment of the atomic bomb, all of which created a constellation of narratives and images that would haunt Morgenthau's work.

\footnotetext{
${ }^{2}$ Woodrow Wilson, Address to Congress (April 2, 1917), accessed February 25, 2011, http://wwi.lib.byu.edu/index.php/Wilson's_War_Message_to_Congress
} 
At the heart of Nazism lay an apocalyptic myth centered on a millenarian account of time that cast the present as a moment of both catastrophe and promise. ${ }^{3}$ History had reached a turning point that would lead either to salvation for some or the annihilation of all. Hitler's mentor, Dietrich Eckart, announced in 1919:

Signs and wonder are seen-from the flood a new world will be born. These Pharisees however whine about wretched nest eggs! It's not simply a question of our collapse - it's a question of our Golgotha! Salvation is to befall our Germany, not misery and poverty. No other people on Earth are so thoroughly capable of fulfilling the Third Reich than ours! Veni Creator spiritus! ${ }^{4}$

This conception of a "Third Reich" as a final and millennial age has its roots in an idiosyncratic appropriation of the writings of Joachim of Fiore, the twelfth-century Calabrian abbot whose apocalyptic theology had influenced Savonarola, among others. ${ }^{5}$ Joachim proposed a tripartite division of history into three ages, or statuses. The third status would begin at the end times, during which a spiritual elect would defeat Antichrist and usher in a final age in which humanity would be transformed. Historians of ideas have proposed that the Nazis might have become aware of Joachim's thought through the secular appropriations of it in the work of Gutthold

\footnotetext{
${ }^{3}$ In making the argument that Nazism relied on apocalyptic narratives and images, I am drawing on and echoing the arguments made by: James M. Rhodes, The Hitler Movement: A Modern Millenarian Revolution (Stanford: Hoover Institution Press, 1980); Robert Wistrich, Hitler's Apocalypse: Jews and the Nazi Legacy (New York: St. Martin's Press, 1985); Thomas Flanagan, “The Third Reich: Origins of a Millenarian Symbol," History of European Ideas 8, no. 4 (1987): 283-295; David Redles, Hitler's Millennial Reich: Apocalyptic Belief and the Search for Salvation (New York: New York University Press, 2005); David Redles, "Nazi End Times: The Third Reich as Millennial Reich," in End of Days: Essays on the Apocalypse from Antiquity to Modernity, ed. Karolyn Kinane and Michael A. Ryan (Jefferson: McFarland and Company, 2009), 173-196. These works elaborate on a set of fragmentary and largely intuitional arguments offered by: Eric Voegelin, The New Science of Politics: An Introduction (Chicago: University of Chicago Press, 1952), 110-27; Norman Cohn, The Pursuit of the Millennium: Revolutionary Messianism in Medieval and Reformation Europe and Its Bearing on Modern Totalitarian Movements, $2^{\text {nd }}$ edition (New York: Harper Torchbooks, 1961), 308-11; Michael Barkun, Disaster and the Millennium (New Haven: Yale University Press, 1974), 192-4.

${ }^{4}$ Dietrich Eckart, as quoted in Redles, "Nazi End Times," 173. Veni Creator spiritus (Come Creator spirit) is a Catholic chant generally reserved for special Church occasions. However, as David Redles explains, "seen from the perspective of Joachite millennialism...the descent of Holy Spirit upon the Earth takes on a more nuanced meaning. 'Golgotha' [is] where the Romans purportedly crucified Jesus. For an anti-Semite like Eckart, however, the linkage of liberation from 'the curse of gold' to the crucifixion is a blaming of Jews for both Germany's economic woes and the death of Jesus." Redles, "Nazi End Times," 189 (n1).

${ }^{5}$ It is worth stressing that Nazism is in no way a natural or logical evolution of Joachim's thought. While protoNazi and Nazi thinkers drew upon Joachim's notion of a third status (i.e. age of the spirit) in their conceptualization of a Third Reich, it should be noted that Joachim never meant "status" to refer to any kind of political entity.
} 
Lessing and strands of German Idealism, ${ }^{6}$ as well as through Henrik Ibsen's Emperor and Galilean (1873), which includes a memorable discussion of a coming 'Third Empire' in which Emperor and God will be one. ${ }^{7}$ These ideas were transformed into a distinctly Nazi understanding of history by Dietrich Eckart and Otto Strasser and through the appropriation of Arthur Moeller van den Bruck's Das Dritte Reich (1923), which argued for the replacement of the Weimar Republic with a Third Reich. According to Moeller van den Bruck, humanity would have to be transformed to "make good again what we have made so bad." themselves ushering in a new age.

Knowledge of this apocalyptic vision came through experiences of conversion and revelation. Alfred Rosenberg, one of the most powerful authors of Nazi ideology, described this experience: "There comes a moment for anyone who is truly searching when, out of thinking and fighting, suddenly an experience arises. From this moment on, the present, past and the outlook of the future appear to him in an entirely different light than before." 9 For Hitler and Herman Göring, the source of these revelations was a racial identity that called them to an eschatological mission..$^{10}$ Nazi organizational reformer Gregor Strasser suggested that this revelation was also a collective experience of turning vague feelings into certain knowledge:

More and more the unclear feeling of young Germans in all camps is becoming a clear realization, that the confusion, the decay of the preceding political, economic, and cultural 'order' is only the visible expression of one of the most thoroughgoing reformations, of the revolutionary stirrings of a new world view...on August 1, 1914, a revolution broke out which, with the most serious

\footnotetext{
${ }^{6}$ Flanagan, "The Third Reich," 285.

7 "JULIAN: Emperor-god; --god-emperor. Emperor in the kingdom of the spirit,--and god in that of the flesh. MAXIMUS: That is the third empire, Julian! JULIAN: Yes, Maximus, that is the third empire. MAXIMUS: In that empire the present watchword of revolt will be realised." Henrik Ibsen, Emperor and Galilean: A World-Historic Drama, ed. William Archer (New York: Scribner and Welford, 1890), 274 (Act III). See also: Redles, "Nazi End Times," 174-5; Flanagan, "The Third Reich," 285-6; Steven F. Sage, Ibsen and Hitler: The Playwright, the Plagiarist, and the Plot for the Third Reich (New York: Basic Books, 2009).

${ }^{8}$ Dietrich Eckart, Das Dritte Reich, as quoted in Redles, "Nazi End Times," 180.

${ }_{9}^{9}$ Alfred Rosenberg, The Volkish Conception of the State (1923), as quoted in Redles, Hitler's Millennial Reich, 77.

${ }^{10}$ Rhodes, Hitler Movement, 39.
} 
convulsions and struggles - of which the World War was only the necessary beginning-will bring forth a new world. ${ }^{11}$

These "convulsions and struggles" were both an impetus to collective revelation and a sign of election. Hitler had claimed in Mein Kampf that Germany had been singled out as a particular target. The German defeat in 1918 was "but the deserved chastisement of eternal retribution." If Germans responded to this chastisement with reform and struggle, it could become "the inspiration of a great future resurrection."12 The German "people" had been chosen to receive a revelation, undergo a terrible retribution, and usher in a new age.

However, this new age had to be inaugurated by an apocalyptic battle between good and evil. While Nazis agreed that Jews were the cause of this evil, they could not agree why. Hitler argued that Jews could not be considered human "in the sense of being an image of God." They were instead "the image of the devil."13 He hypothesized that Jews were once "veritable devils" but had taken on human form over time. ${ }^{14}$ Other Nazis simply thought Jews behaved in an evil way. Regardless of these disagreements, Nazis were agreed that the source of this evil had to be eliminated. If they were successful, this war would give birth to a new world. Yet as Hitler told an audience in 1925, the stakes were high: "As we banded together in this new movement, we made it clear to ourselves that in this contest there are only two possibilities: Either the enemy will walk over our corpses, or we will walk over his."15 By 1943, Heinrich Himmler, Reichsführer of the Schutzstaffel, sensed that he had to remind his subordinates of their mission. He argued that while many Germans seemed to support Jewish extermination on principle, "each

\footnotetext{
${ }^{11}$ Gregor Strasser, Kampf um Deutschland (1932), as quoted in Rhodes, Hitler Movement, 59.

12 Adolf Hitler, Mein Kampf (1925/6), as quoted from the 1943 Ralph Mannheim translation in Rhodes, Hitler Movement, 60. Note the absence of agency here. Unlike overtly religious forms of apocalypticism in which God singles out particular people or groups for chastisement, Hitler does not identify a selective agent. The implication is that "fate" or "history" has singled out Germany.

${ }^{13}$ Hitler, Mein Kampf, as quoted from the 1943 Mannheim translation in Wistrich, Hitler's Apocalypse, 30.

${ }^{14}$ Hitler, Mein Kampf, as quoted from the 1943 Mannheim translation in Rhodes, Hitler Movement, 45.

${ }^{15}$ As quoted in Rhodes, Hitler Movement, 64.
} 
of them has his 'decent' Jew" whom he thought should be exempt. He continued: "Not one of all those who talk this way has witnessed it...Most of you know what it means when a hundred corpses are lying side by side, or five hundred, or a thousand...We had the moral right, we had the duty to our people, to destroy this people which wanted to destroy us." ${ }^{" 16}$ Upon the success of this extermination effort depended the creation of a new world and the salvation and redemption of the Volk. $^{17}$ In sum, while its aspirations for a racially-based program of extermination are unique, Nazism shared with the apocalyptic movements of late fifteenth-century Florence and seventeenth-century England a narrative of the present as an extraordinary moment of both catastrophe and promise that would usher in a new age.

While the Nazi millennium failed to come, Hitler's program of extermination did succeed in creating what was for many a lived apocalypse. Histories of apocalypticism tend to offer ample coverage of the eschatological narratives of Nazism and the development and deployment of the atomic bomb, while neglecting to consider the ways in which the Holocaust helped shape the twentieth-century apocalyptic imaginary. There are at least two problems with this neglect. First, it fails to recognize that the apocalypse was the lens through which some survivors and Jewish thinkers came to understand the Holocaust. I take Elie Wiesel's thoughtful and troubling essay, "A Vision of the Apocalypse," as illustrative of such an interpretation. ${ }^{18}$ Wiesel explains:

\footnotetext{
${ }^{16}$ As quoted in Rhodes, Hitler Movement, 56. Himmler is making a rhetorical move here that Hannah Arendt diagnoses as an attempt to overcome the animal pity one feels for others in the face of physical suffering. This move consists "in turning these instincts around, as it were, in directing them toward the self. So that instead of saying: What horrible things I did to people!, the murderers would be able to say: What horrible things I had to watch in the pursuance of my duties, how heavily the task weighted upon my shoulders!" See: Hannah Arendt, Eichmann in Jerusalem: A Report on the Banality of Evil (New York: Penguin, 1977), 106.

${ }^{17}$ Like other apocalyptic movements, Nazism did not offer a coherent account of the world to come. Some seemed to have thought that Germans would transform into divine beings. Others expected an immanent, worldly immortality through the eternal salvation of the Volk. For most, the world to come was likely more mundane, though still mythical - a reconstructed Germany that would be protected from future disasters. The common thread in these visions was the transformation of humanity and the founding of a new society, from which Jews and German dissenters had been purged. See: Rhodes, Hitler Movement, 77-82.

${ }^{18}$ I want to stress two things here. First, Wiesel's essay is illustrative, but by no means representative, of an apocalyptic reading of the Holocaust. In this instance, I do not think any reading could be cast as representative.
} 
"To the extent that my contemporaries believe in the Apocalypse, they refer to the one they lived through. They speak of memory more than vision." ${ }^{19}$ For him, the calm slaughter of thousands of Jews in a single day, doctors separating potential experimental subjects from those destined for the gas chambers, and lawyers crafting the Final Solution at the Wannsee Conference mark a fundamental shift in the apocalyptic imaginary. The apocalypse is "no longer great beasts spewing forth flames, or horsemen ushering in destruction, or homes ransacked and collapsing in an earthquake imparting to History a hallucinatory, fiery end." Rather, it is "a spacious and welllighted office, well-bred technocrats, efficient secretaries. It is government employees working together with or without passion, with or without conviction, first to imagine, then to bring about, Auschwitz. ${ }^{20}$ This is an apocalypse devoid of divine or Satanic agency. It is carried out by calm, cultured professionals who "had all read Goethe and admired Schiller."21

Yet this account of the experience at Auschwitz shares more with older religious apocalypses than Wiesel admits. Both are ruptures in the temporal continuity of history. For Wiesel, even as Auschwitz negates history, it "represents a kind of aberration and culmination of History. Everything brings us back to it. Illuminated by its flames, the present appears more understandable. ${ }^{22}$ It is the culmination of a history of anti-Semitism, persecutions, expulsions, and violence. It offers a terrifying revelation of truths about European culture that had been hidden or only half visible for centuries. Finally, the Holocaust ushers in a fundamentally new world, but not one of redemption and salvation. Instead, it is a new world that bears symptoms

Second, an apocalyptic reading of the Holocaust is not unproblematic or uncontested. See, for instance: David G. Roskies, Against the Apocalypse: Reponses to Catastrophe in Modern Jewish Culture (Cambridge: Harvard University Press, 1984); Michael André Bernstein, Forgone Conclusions: Against Apocalyptic History (Berkeley: University of California Press, 1994).

${ }^{19}$ Elie Wiesel, “A Vision of Apocalypse," trans. Joan Grimbert, World Literature Today 58, no. 2 (1984): 195.

${ }^{20}$ Wiesel, "A Vision of Apocalypse," 196.

${ }^{21}$ Wiesel, "A Vision of Apocalypse," 196.

${ }^{22}$ Wiesel, "A Vision of Apocalypse," 195. 
and traces of terrifying and irrevocable events. ${ }^{23}$ Wiesel ends his essay by considering whether the apocalypse of Auschwitz could be transposed into the future. He does not fear a return to ghettos and gas chambers, but rather the possibility that the culture of indifference and apathy that permitted the Holocaust would now fail to prevent a nuclear apocalypse.

The second problem, then, with avoiding the Holocaust in an account of the twentiethcentury apocalyptic imaginary is that it blinds us to the connections between the Final Solution and the dawn of a nuclear age. For Wiesel, the two constellations of events are clearly linked: "for us, time stopped between Auschwitz and Hiroshima." ${ }^{24}$ This connection is by no means particular to Wiesel. For many, the images and lived experiences of Nazi genocide became a way to imagine the possibility of nuclear annihilation. A 1952 New York Times review of The Diary of Anne Frank noted how successful this work is "in bringing us an understanding of life under threat. And this quality brings it home to any family in the world today. Just as the Franks lived in momentary fear of the Gestapo's knock on their hidden door, so every family today lives in fear of the knock of war. ${ }^{25}$ In the early 1950s, this knocking hand would have certainly been that of atomic war.

In a 1962 piece in The Atlantic Monthly, poet and critic A. Alvarez went further and hypothesized that our fear of nuclear annihilation was one of the reasons the concentration camps had captured the popular imagination:

There are no limits to the inflationary spiral of destruction. From 1940 to 1945 nearly 4,500,000 people died in Auschwitz. The same number would die in minutes if a hydrogen bomb landed on London. The gap is very small between the comforts of our affluent society and the bare, animal squalor of Birkenau, or the finality of the Auschwitz crematorium, with its rasping iron trolleys. So,

\footnotetext{
${ }^{23}$ James Berger, After the End: Representations of Post-Apocalypse (Minneapolis: University of Minnesota Press, 1999), 61.

${ }^{24}$ Weisel, "A Vision of the Apocalypse," 195.

${ }^{25}$ Meyer Levin, "The child behind the secret door [Review of Anne Frank: The Diary of a Young Girl]" New York Times (June 15, 1952): BR 1.
} 
perhaps the concentration camps have kept a tight hold on our imaginations... [because] we see them as a small-scale trial run for nuclear war. ${ }^{26}$

Alvarez' shift from comparative calculations to the images of Auschwitz is important herefrom the abstract, unthinkable, enormous numbers to the "animal squalor," the crematorium, and the "rasping iron trolleys." The analogy between the concentration camp and the effects of nuclear destruction is not merely or even primarily one based on comparative death tolls, but on a shared visual vocabulary of annihilation. More than 20 years later, nuclear physicist I.I. Rabi would rely exclusively on imagistic association: "And now we have the nations lined up, like those prisoners at Auschwitz, going into the ovens, and waiting for the ovens to be perfected, made more efficient." ${ }^{27}$ It is with these images of extermination, in addition to the haunting reports from Hiroshima and Nagasaki, that postwar America imagined nuclear annihilation.

These imagistic associations emphasize an apocalypse initiated by human and technological agency, after which there is no redemption. This is entirely consistent with the picture of the nuclear age in many scholarly treatments of apocalypticism. ${ }^{28}$ The possibility of a nuclear apocalypse seems fundamentally different than the ends of the world envisioned in the past. These older apocalyptic visions are part of a religious cosmology in which "man is acted upon by a higher power who has his reasons, who destroys for spiritual purposes (such as achieving the 'Kingdom of God'). That is a far cry from man's destruction of himself with his

\footnotetext{
${ }^{26}$ A. Alvarez, "The Concentration Camps," The Atlantic Monthly (December 1962): 70. The fact that Alvarez makes this connection in the early 1960s is perhaps not surprising. This was the period in which the Nazi genocide and nuclear annihilation were linked by a shared referent. While the word 'holocaust' was only starting to become the primary referent for the Nazi genocide in the early 1960s, it was a common referent for nuclear annihilation. See: Jon Petrie, “The secular word HOLOCAUST: scholarly myths, history, and $20^{\text {th }}$ century meanings," Journal of Genocide Research 2, no. 1 (2000): 43-50.

${ }^{27}$ I.I. Rabi, as quoted in Robert Jay Lifton and Eric Markusen, The Genocidal Mentality: Nazi Holocaust and Nuclear Threat (New York: Basic Books, 1990), 9.

${ }^{28}$ For a notable exception that deals explicitly with religious and theological visions of nuclear apocalypse, see: Paul Boyer, When Time Shall Be No More: Prophecy Belief in Modern American Culture (Cambridge: Belknap/Harvard University Press, 1992), 115-151.
} 
own tools, and to no purpose." 29 With the advent of nuclear weapons, humans became the agents of the apocalyptic drama. ${ }^{30}$ Nuclear technology was also invested with agency of its own, powers that exceeded our capacities for understanding and control. Consider, for example, the popular notion from the 1950 s that there were "doomsday buttons" in both the White House and the Kremlin. The world could be brought to an end as easily as turning on a television set or a dishwasher. This notion of a push-button apocalypse "reinforced feelings of helplessness and apocalyptic inevitability. Once the button was pushed, nothing could be done to stop the process because the technology was...overwhelmingly sophisticated and beyond one's understanding and control." 31 It is this sense of helplessness, inevitability, and technological agency that is so effectively parodied and critiqued in Stanley Kubrick's Dr. Strangelove (1964). And, unlike the God of the Judeo-Christian apocalypse, nuclear weapons would not usher in a redemptive new world. The human species, along with its material and intellectual achievements, would simply be extinguished.

This standard account of nuclear apocalypticism captures some important shifts in the collective imaginary. However, it overstates the contrast between nuclear apocalypticism and the more overtly religious movements to which Machiavelli and Hobbes, for instance, were responding. As we have seen in the two previous chapters, apocalyptic agency is rarely left entirely to God. Both Savonarola and the more radical apocalypticists of the English Civil War

\footnotetext{
${ }^{29}$ Robert J. Lifton, "The Image of 'the End of the World': A Psychohistorical View" in Visions of Apocalypse: End or Rebirth?, ed. Saul Friedländer, Gerald Holton, Leo Marx, and Eugene Skolnikoff (New York: Holmes and Meier, 1985), 164.

${ }^{30}$ Daniel Wojcik acknowledges, quite rightly, that there are ample examples of apocalypses driven by human agency in $19^{\text {th }}$ century literature (e.g. Mary Shelley's The Last Man) and political ideas (e.g. strands of Marxism). He concludes, however, that "these nineteenth- and early twentieth-century visions of worldly destruction and transformation were usually optimistic in their evaluation of apocalypse, viewing it not as the end of the world but the beginning of the transformation of society." He contrasts this with postwar visions that were "increasingly pessimistic, stressing cataclysmic disaster as much as previous millenarian visions emphasized the imminent arrival or a redemptive era." See: Daniel Wojcik, The End of the World as We Know It: Faith, Fatalism, and Apocalypse in America (New York: New York University Press, 1997), 97-8. I shall have more to say on this characterization of postwar apocalypticism below.

${ }^{31}$ Wojcik, 103.
} 
carved out substantial space for human agency in their apocalyptic projects. Even more importantly, this standard account of nuclear apocalypticism fundamentally ignores the optimistic apocalyptic narratives surrounding the development and deployment of these new weapons. The explicit contrast invoked by the standard account is between a divine apocalypse that promises spiritual renewal and a human and technological apocalypse that brings total annihilation. This contrast forces the same false choice that Leonard Cohen offers in his darkly apocalyptic song "The Future": "Give me Christ or give me Hiroshima.",32 As we shall see below, the postwar apocalyptic imaginary often blended a fear of total annihilation with a hope for worldly renewal, giving us both Christ and Hiroshima.

For example, it was with profoundly redemptive hopes that J. Robert Oppenheimer, the scientific director of the Manhattan Project, chose the code name for the first full-scale test of the atomic bomb. General Leslie Groves, the director of the Manhattan Project, wrote to Oppenheimer in 1962 to ask why the physicist had coded the test "Trinity." Oppenheimer wrote back: "Why I chose the name is not clear, but I know what thoughts were in my mind. There is a poem of John Donne, written just before his death which I know and love. From it a quotation: 'As West and East/ In all flatt Maps - and I am one - are one,/ So death doth touch the Resurrection.",33 These lines are from Donne's "Hymne to God my God in my sicknesse" and they establish the theological connection between death and resurrection. ${ }^{34}$ Oppenheimer's letter to Groves continues: “That still doesn't make a Trinity, but in another, better known devotional

\footnotetext{
${ }^{32}$ Leonard Cohen, "The Future," The Future, 1992, Columbia.

33 As quoted in Richard Rhodes, The Making of the Atomic Bomb (New York: Simon and Schuster, 1986), 571.

${ }^{34}$ John Donne biographer Robert Stubbs suggests that there may be another possible reading here. Given that Oppenheimer recounted this story to Groves in 1962, "after the McCarthy witch-hunt, ... he may have been using the reference less to explain the meaning of 'Trinity' than to discredit the bi-polar division of the Cold War world he had helped to create. East and West were illusions of a map; if one put the chart around the globe, those extremities merged together into one.” See: Robert Stubbs, John Donne: The Reformed Soul (New York: W.W. Norton, 2007), 477. I find this interpretation difficult to sustain, given that Oppenheimer goes on to cite a second Donne poem that cannot be so easily connected to the particular Cold War context of the early 1960s.
} 
poem Donne opens, 'Batter my heart, three person'd God'; --Beyond this, I have no clues whatever." ${ }^{35}$ Like Donne's "Hymne," this sonnet connects destruction and redemption: "Batter my heart, three person'd God; for, you/ As yet but knocke, breathe, shine, and seeke to mend;/ That I may rise, and stand, o'erthrow mee,'and bend / Your force to breake, blowe, burn and make new." ${ }^{36}$ Here, Donne begs God to batter, bend, break, and burn him in order that he may be made new. This connection between destruction and redemption may have been especially meaningful for Oppenheimer, who sustained himself during the Manhattan Project with the hope that nuclear weapons could be used to overpower evil and usher in a new world without war. ${ }^{37}$

Upon witnessing the Trinity test on July 16, 1945, he would reach for a much darker and non-Western theological vision. Oppenheimer recalled the lines from the Bhagavad Gita: "If the radiance of a thousand suns/ Were to burst at once into the sky/ That would be like the splendor of the Mighty One.../ I am become Death,/ The shatterer of worlds. ${ }^{\text {"38 }}$ In contrast to the redemptive hope of "Trinity," his remarks here suggest an overwhelming confrontation with death and annihilation.

\footnotetext{
${ }^{35}$ As quoted in Richard Rhodes, The Making of the Atomic Bomb, 572.

${ }^{36}$ The sonnet continues with a combination of military and sexual imagery: "I, like an usurpt towne, to'another due,/ Labour to'admit you, but Oh, to no end,/ Reason your viceroy in mee, mee should defend,/ But is captiv'd, and proves weake or untrue./ Yet dearly'I love you,'and would be loved faine, / But am betroth'd unto your enemie:/ Divorce mee,'untie, or breake that knot againe,/ Take mee to you, imprison mee, for I/ Except you'enthrall mee, never shall be free,/ Nor ever chast, except you ravish mee." See: John Donne, "Holy Sonnet XIV," in The Complete Prose and Selected Poetry of John Donne, ed. Charles M. Coffin (New York: Modern Library, 2001), 264.

${ }^{37}$ Richard Rhodes cites Hans A. Bethe, head of the Theoretical Division at the Los Alamos Laboratory, explaining that Oppenheimer developed these ideas about the moral possibilities of nuclear weapons in conversations with Niels Bohr, who put great faith in the potential for international control. See: Rhodes, The Making of the Atomic Bomb, 572. In a communication with Robert Lifton, Oppenheimer biographer Nuel Pharr Davis said: "In talking with me about the name trinity Oppenheimer showed himself apologetic about the rather high-flown poetic derivation but not apologetic about the moral assumption." See: Robert Lifton, The Broken Connection: On Death and the Continuity of Life (New York: Simon and Schuster, 1979), 370.

${ }^{38}$ As quoted in Lifton, The Broken Connection, 370.
} 
Brigadier General Thomas Farrell drew on more explicitly Christian imagery in his contribution to General Groves' official report that was sent to President Truman during the Potsdam Conference with Winston Churchill and Joseph Stalin:

The effects could well be called unprecedented, magnificent, beautiful, stupendous, and terrifying...The whole country was lighted by a searing light with the intensity many times that of the midday sun. It was golden, purple, violet, gray and blue. It lighted every peak, crevasse and ridge of the nearby mountain range with a clarity and beauty that cannot be described but must be seen to be imagined. It was that beauty the great poets dream about but describe most poorly and inadequately. Thirty seconds after the explosion came, first, the air blast pressing hard against the people and things, to be followed almost immediately by the strong, sustained, awesome roar which warned of doomsday and made us feel that we puny things were blasphemous to dare tamper with the forces heretofore reserved to The Almighty. Words are inadequate tools for the job of acquainting those not present with the physical, mental and psychological effects. It had to be witnessed to be realized. ${ }^{39}$

Farrell offers an overtly apocalyptic and sublime vision of an event so ruptural and magnificent that it escapes description. It can only be witnessed. Upon receiving this report, President Truman reached for images of biblical destruction: "We have discovered the most terrible bomb in the history of the world. It may be the fire destruction prophesied in the Euphrates Valley Era, after Noah and his fabulous Ark." ${ }^{40}$ Winston Churchill's reaction a few days later was even darker: "This atomic bomb is the Second Coming in Wrath."41

If anything, these darkly apocalyptic visions intensified after the United States dropped the atomic bombs on Hiroshima and Nagaski on August 6 and August 9, 1945, respectively. ${ }^{42}$

\footnotetext{
${ }^{39}$ Thomas F. Farrell, as quoted in Leslie R. Groves, Memorandum for the Secretary of War (July 18, 1945), point 11. This memorandum is reproduced in Appendix P of: Martin J. Sherwin, A World Destroyed: Hiroshima and the Origins of the Arms Race (New York: Vintage, 1987), 308-14. The quotation from Farrell appears on p. 312.

${ }^{40}$ As quoted in Herbert Mitgang, "Truman's Newly Found Potsdam Notes Show Concerns on A-Bomb," New York Times (June 2, 1980): A14.

${ }^{41}$ As quoted in Harvey H. Bundy, "Remembered Words," The Atlantic (March 1957): 57.

${ }^{42}$ In this section of the chapter, I have chosen to focus on those views of nuclear weapons that stress their radical newness. The fact that the scientists who designed the atomic bomb as well as the President who deployed it stressed its radical newness is significant. However, there were numerous public figures and scholars (including initially Morgenthau) who argued that nuclear weapons did not represent a qualitative shift away from conventional weapons. In the context of the comparative death tolls during World War II, this position was not unreasonable.
} 
Initially, however, the responses to the news from Japan were triumphant. Upon hearing of the success of the bomb dropped on Hiroshima, President Truman proclaimed: "This is the greatest thing in history!”43 It was a sign of the unprecedented military and technological power of the United States. Yet for many, the destruction of Hiroshima and Nagaski did not call forth images of an all-powerful America, but of a vulnerable and exposed country awaiting its own annihilation. In an August 12 piece in the New York Times, Washington correspondent James Reston suggested: "In that terrible flash 10,000 miles away, men here have seen not only the fate of Japan, but have glimpsed the future of America." ${ }^{44}$ In a similar vein, broadcast journalist Edward R. Murrow worried: "Seldom, if ever, has a war ended leaving the victors with such a sense of uncertainty and fear, with such a realization that the future is obscure and that survival is not assured. ${ }^{\circ 5}$ On the brink of Japanese surrender and at the dawn of the nuclear age, many in America stared into the future and saw nothing but the possibility of apocalyptic annihilation. ${ }^{46}$

The fire-bombing of Tokyo had killed at least 100,000 people, while final death tolls at Hiroshima and Nagasaki were 135,000 and 50,000, respectively. The argument that nuclear weapons did not represent a qualitative shift from conventional weapons became much more difficult to maintain with the advent of the hydrogen bomb.

${ }^{43}$ President Harry S. Truman, as quoted in Sherwin, A World Destroyed, 221.

${ }^{44}$ James Reston, "Dawn of the Atom Era Perplexes Washington," New York Times (August 12, 1945): E6.

${ }^{45}$ Edward R. Murrow, August 12, 1945 Radio Broadcast, in In Search of Light: The Broadcasts of Edward R. Murrow, 1938-1961, ed. Edward Bliss, Jr. (London: Macmillan, 1968), 102.

${ }^{46}$ Paul Boyer suggests that advocates of international control of nuclear weapons deliberately encouraged and exploited this response. "Without international control of the atom, Americans were endlessly warned, the fate of these two cities would be theirs as well. Highly effective as propaganda, this shorthand use of 'Hiroshima' and 'Nagaski' as abstract cautionary devices further diminished the capacity of Americans to respond directly to the actual fate of two real cities. The emotional thrust of the 1946 fear campaign was directed forward to possible future atomic holocausts, not backward to what had already occurred." See: Paul Boyer, Fallout: A Historian Reflects on America's Half-Century Encounter with Nuclear Weapons (Columbus: Ohio State University Press, 1998), 14. Spencer Weart argues that Hiroshima and Nagasaki presented Americans with "dangerously incomplete" images of nuclear annihilation. The United States government released very few photographs of those who were wounded in Japan. Rather, "the commonly seen Hiroshima pictures mostly showed vast landscapes of rubble, empty of victims...The destruction was usually viewed from an Olympian distance, as in the frequently published maps that showed with concentric circles how many square miles of a city would be pulverized." See: Spencer R. Weart, Nuclear Fear: A History of Images (Cambridge: Harvard University Press, 1988), 236. To some extent, however, images of nuclear annihilation escaped government control. John Hersey's Hiroshima, originally published in a 1946 issue of the New Yorker offered the following narrative of the destruction, re-created with the help of survivor accounts: "He was the only person making his way into the city; he met hundreds and hundreds who were fleeing, and every one of them seemed to be hurt in some way. The eyebrows of some were burned off and skin hung from their faces and hands. Others, because of pain, held their arms up as if carrying something in both hands. Some were vomiting as they walked. Many were naked or in shreds of clothing. On some undressed bodies, the burns had 
These reactions, along with some of the initial responses to the Trinity test, seem to provide support for the standard reading of nuclear apocalypticism. They suggest an apocalypse created by human agents who have let loose a technology that they cannot control and that holds them in awe. There is no suggestion of spiritual or worldly renewal.

Yet, for others, the dawn of the nuclear age marked the birth of a new world and promised a kind of earthly salvation. William Laurence, the New York Times journalist covering the Manhattan Project, seems to have experienced a kind of apocalyptic conversion upon witnessing the Trinity test. He compared it to what the first man might have seen "at the moment of Creation when God said, 'Let there be light." ${ }^{47}$ Later that day, he found himself saying: "It was like being witness to the Second Coming of Christ!" apocalyptic conversion is even stronger in Laurence's description of his reactions to the May 21, 1956 test of an airborne hydrogen bomb in the northern Pacific. He recounts that his first thoughts were of the damage that such a weapon could do to "any of the world's great cities." But reassurance was almost instantaneous: "This great iridescent cloud and its mushroom top, I found myself thinking as I watched, is actually a protective umbrella that will forever shield mankind everywhere against the threat of annihilation in any atomic war." This phenomenal new weapon with over 700 times the power of the bombs dropped on Hiroshima and Nagasaki would "continue shielding us everywhere until the time comes, as come it must, when mankind

made patterns - of undershirt straps and suspenders and, on the skin of some women (since white repelled the heat from the bomb and dark clothes absorbed it and conducted it to the skin), the shapes of flowers they had had on their kimonos." See: John Hersey, Hiroshima (New York: Alfred A. Knopf, 1985), 39-40.

${ }^{47}$ William L. Laurence, Men and Atoms: The Discovery, the Uses and the Future of Atomic Energy (New York: Simon and Schuster, 1959), 118. Laurence also wrote the following remarks in his notebook that day: "With the flash came a delayed roll of mighty thunder, heard, just as the flash was seen, for hundreds of miles. The roar echoed and reverberated from the distant hills and the Sierra Oscuro range near by, sounding as though it came from some supramundane source as well as from the bowels of the earth. The hills said yes and the mountains chimed in yes. It was as if the earth had spoken and the sudden iridescent clouds and sky had joined in one affirmative answer. Atomic energy-yes." Laurence, Men and Atoms, 120.

${ }^{48}$ Laurence, Men and Atoms, 120. 
will be able to beat atomic swords into plowshares, harnessing the vast power of the hydrogen in the world's oceans to bring in an era of prosperity such as the world has never even dared dream about." 49 For Laurence, the devastation wrought by the atomic bombs dropped on Japan and the hydrogen bomb's potential for unimaginable annihilation had already initiated an apocalyptic transformation and the dawning of a new world. The actual deployment of these bombs in populated areas could not even be contemplated. Total war was a thing of the past.

However, others were willing to contemplate a world that might come into being after thermonuclear war. From the 1950s onward, numerous articles, books, and films considered the possibilities of a post-apocalyptic world. These works offered a full range of possibilities - from the dire to the unapologetically optimistic. ${ }^{50}$ But the dire scenarios were those that most troubled the United States government. Since the end of the Second World War, policymakers had begun to worry that public knowledge of the devastating effects of nuclear war might make Americans less willing to "support national policies which might involve the risk of nuclear warfare." 1956, the National Security Council ordered a classified study of the effects of the threat of nuclear annihilation on American attitudes and behavior. A panel of social scientists completed a report entitled "The Human Effects of Nuclear Weapons Development." The report recommended a widespread program of "town hall meetings," aimed at balancing public awareness of the effects of nuclear weapons with an "increased knowledge and understanding of both the broad aspects of national security... and the specific countermeasures that can reduce the

\footnotetext{
${ }^{49}$ Laurence, Men and Atoms, 197.

${ }^{50}$ For a discussion of some of these books and films, see Kenneth D. Rose, One Nation Underground: The Fallout Shelter in American Culture (New York: New York University Press, 2001), 38-77. These works provide a range of attitudes toward the possibilities of survival after a nuclear apocalypse, ranging from the acceptant pessimism of Nevil Shute's On the Beach (1957, with a film adaptation in 1959) to an unabashed optimism and faith in the regenerative possibilities of a robust civil defense program in Philip Wylie's Tomorrow! (1954).

${ }^{51}$ Memorandum for the President, Val Peterson (Federal Civil Defense Administration) to Dwight D. Eisenhower, as quoted in Wm. F. Vandercook, "Making the Very Best of the Very Worst: The "Human Effects of Nuclear Weapons' Report of 1956," International Security 11, no. 1 (1986): 184.
} 
effects of nuclear attack." 52 The report concluded by noting that nuclear war might actually provide survivors with an opportunity for heroism and renewal:

The extremity of human disaster might become the opportunity for resolute survivors. It is a brave thing, admittedly, to brace ourselves against the threat of annihilation. It is another, and better, thing to nerve ourselves to make the very best of the very worst. At this historic crossroads we would begin with knowledge and we would end with wisdom. Thus to take counsel with one another, to the very town meeting grass roots, would be to draw inspiration from our forefathers and to point our children to the sources which make all American generations one and which raise hope for a new dynamics for the human race. It is a vision, indeed, but where visions flourish nations endure. ${ }^{53}$

While "The Human Effects" report was eventually shelved, it suggests a strong concern with tempering fears of nuclear annihilation with patriotic and apocalyptic optimism.

Even without the implementation of the report's "town hall" public relations program, some continued to see reasons for optimism in a post-apocalyptic future. These optimists turned to the predictions of thinkers like Herman Kahn, a systems theorist at the RAND Corporation, who argued that despite the hostility of a post-nuclear-war environment, survivors might still enjoy "relatively normal and happy lives." He even predicted that within a few years, the standard of living "would be higher than the standards prevalent in the U.S. between 1900 and 1930." ${ }^{, 54}$ These kinds of optimistic predictions, combined with President Kennedy’s 1961 civil defense and fallout shelter initiative, helped fuel radical hopes. In an October 1961 editorial, Life magazine argued that a shelter-building campaign "will give all Americans the hope that they, like their forebears, can some day abandon the stockades to cross whatever new mountains of adversity or trial may lie ahead." ${ }^{, 55}$ Later that month, an article in Time magazine struck a similar

\footnotetext{
52 "The Human Effects of Nuclear Weapons Development" Report, as quoted in Vandercook, "Making the Very Best," 193.

53 "The Human Effects of Nuclear Weapons Development" Report, as quoted in Vandercook, "Making the Very Best," 193.

${ }^{54}$ Herman Kahn, Thinking About the Unthinkable (New York: Avon, 1962), 91.

55 "Let's Prepare...Shelters," Life (October 13, 1961): 4.
} 
note: "Only two days after the thermonuclear attack, many adults might start emerging from the protection of their shelters for brief periods...[W]ith trousers tucked into sock tops and sleeves tied around wrists, with hats, mufflers, gloves and boots, the shelter dweller could venture forth to start ensuring his today and building for his tomorrow." the cramped "womb" of the fallout shelter suggest a rebirth and an opportunity for a uniquely American exercise of courage - a kind of post-apocalyptic pioneer spirit. ${ }^{57}$ What the "Human Effects" and these more popular images attempt to elicit is not just the hope that Americans could survive a nuclear attack. Rather, they go beyond nuclear optimists like Kahn and present an enticing image of a clean slate and an opportunity to create the world anew and engender "a new dynamics of the human race." This is the vision of creative renewal through destruction for which the standard story of nuclear apocalypticism fails to account.

In sum, then, the postwar apocalyptic imaginary was comprised of a constellation of images and narratives drawn from the most troubling events of the twentieth century. From the apocalyptic narratives underpinning Nazism, through the lived apocalypse of the Holocaust, to the combination of dread and hope of the nuclear age, the postwar imaginary resists any easy characterizations. What is clear, however, is the hold that both the terrifying violence and the radical hopes of the Judeo-Christian apocalypse had over the modern 'secular' imagination.

\section{Apocalypse 'Under an Empty Sky'}

In what follows, I situate Morgenthau's postwar work in the context of this apocalyptic imaginary. Having left Germany for Switzerland in 1932, Morgenthau immigrated to the United

\footnotetext{
56 “Civil Defense: The Sheltered Life," Time, October 20, 1961, accessed March 13, 2011, http://www.time.com/time/magazine/article/0,9171,872787-9,00.html

57 The September 15, 1961 issue of Life included a picture of a teenaged girl relaxing in a distinctly womb-like fallout shelter, enjoying a bottle of Coca-Cola and chatting on the telephone (p. 107).
} 
States the following year. After teaching briefly at Brooklyn College and the University of Kansas City, he accepted an appointment at the University of Chicago in 1943 and remained there for almost thirty years. His time at Chicago overlapped with that of both Leo Strauss and Hannah Arendt, both of whom Morgenthau acknowledged as influential to his own thought. It was during his early years at Chicago that Morgenthau completed three of his most influential books-Scientific Man vs. Power Politics (1948), Politics Among Nations (1948), and In Defense of the National Interest (1951). Together, these books helped to secure Morgenthau's status as a "founding father" of the study of International Relations in the United States. ${ }^{58}$ His work, particularly the immensely influential Politics Among Nations, and the political realist school of which he was a formative member, set the terms of debate in International Relations until the end of the 1960s. ${ }^{59}$

In what follows, I offer a reading of Morgenthau's thought that situates his work in the context of the apocalyptic imaginary of postwar America. I argue that from the late 1940s to the early 1960s, he offered a vigorous critique of the apocalyptic tendencies of secularized political religions. This political theological interpretation differs from the dominant portrait of Morgenthau's early postwar work, and Scientific Man versus Power Politics in particular, a critique of rationalism and scientism. ${ }^{60}$ To be sure, there is substantial textual support for this

\footnotetext{
${ }^{58}$ Stanley Hoffman, Janus and Minerva: Essays in the Theory and Practice of International Politics (Boulder: Westview Press, 1987), 6.

${ }^{59}$ John Vasquez presents preliminary small-N data (gathered from surveys from the early 1970s) to support these claims. See: John A. Vasquez, The Power of Power Politics: From Classical Realism to Neo-Traditionalism (Cambridge: Cambridge University Press, 1998), 63-9.

${ }^{60}$ See, for instance: William E. Scheuerman, Hans Morgenthau: Realism and Beyond (Cambridge: Polity Press, 2009), 41-50; Christoph Frei, Hans J. Morgenthau: An Intellectual Biography (Baton Rouge: Louisiana State University Press, 2001), 194-201. For a reading of Morgenthau that emphasizes his critique of rationalism, whilst trying to distance his ideas from those of Schmitt, see: Michael C. Williams, The Realist Tradition and the Limits of International Relations (Cambridge: Cambridge University Press, 2005), 84-104. I am inclined to agree with Nicolas Guilhot when he argues that Williams overstates the differences between Morgenthau and Schmitt: "Rather than a matter of substantial difference, it is indeed a striking example of what Freud called 'the narcissism of small differences': for Morgenthau, cultivating his own distinctiveness was all the more necessary since his position [in this case, on the concept of the political] was largely identical with Schmitt's. In the deteriorating climate of the
} 
dominant portrait. Morgenthau's Scientific Man reproduces, without ever citing, the narrative and critique that Carl Schmitt offers in his 1929 essay "The Age of Neutralizations and Depoliticizations." Following Schmitt, Morgenthau argues that liberal rationalism aims at nothing short of the "repudiation of politics." An ideological product of the ambitious hope of the Enlightenment, liberal rationalism denies that the "lust for power" is both an ineradicable feature of human nature and the root cause of conflict. Liberalism sees the power struggles that define the political condition as the vestiges from the pre-modern era, embarrassments to be overcome by technical means. Mass education, careful institutional design, free markets, and regimes of international law will form the basis for a new order in which the undesirable aspects of human nature have been overcome and harmony has taken the place of conflict. ${ }^{61}$

The interpretation that I offer below does not deny that Morgenthau's early postwar work can be read as a critique of liberal rationalism. Instead, I ask the reader to consider that Morgenthau might have taken more than this critique from his "hidden dialogue" with Schmitt. ${ }^{62}$

1930s, as Schmitt was on his way to becoming the Kronjurist of the Reich, minor conceptual differences acquired huge symbolic significance." See: Nicolas Guilhot, "American Katechon: When Political Theology Became International Relations Theory," Constellations 17, no. 2 (2010): 252, fn. 99. This may also offer at least a partial explanation for why Morgenthau fails to cite Schmitt even in those moments at which the former most relies on the arguments of the latter.

${ }^{61}$ This argument is outlined in: Hans J. Morgenthau, Scientific Man vs. Power Politics (Chicago: University of Chicago Press, 1946), 41-74.

${ }^{62}$ William Scheuerman classifies Morgenthau's connection to Schmitt as a 'hidden dialogue,' borrowing the term from Heinrich Meier, Carl Schmitt and Leo Strauss: The Hidden Dialogue (Chicago: University of Chicago, 1985). Scheuerman's designation strikes me as entirely accurate, given that both thinkers seem to have engaged with and borrowed from one another's ideas, without any overt attribution. See: William E. Scheuerman, "Carl Schmitt and Hans Morgenthau: Realism and beyond," in Realism Reconsidered: The Legacy of Hans Morgenthau in International Relations, ed. Michael C. Williams (Oxford: Oxford University Press, 2007), 62-92; Carl Schmitt: The End of Law (Lanham: Rowman \& Littlefield, 1999), 225-52. On the Schmitt-Morgenthau connection, see: Guilhot, "American Katechon," 224-53; Chris Brown, "The Twilight of International Morality'? Hans J. Morgenthau and Carl Schmitt on the end of the Jus Publicum Europaeum," in Realism Reconsidered: The Legacy of Hans Morgenthau in International Relations, ed. Michael C. Williams (Oxford: Oxford University Press, 2007), 42-61; Martti Koskenniemi, The Gentle Civilizer of Nations: The Rise and Fall of International Law 1870-1960 (Cambridge: Cambridge University Press, 2001), 413-509; Christoph Frei, Hans J. Morgenthau: An Intellectual Biography (Baton Rouge: Louisiana State University Press, 2001), 118-9, 123-32; Hans-Karl Pichler, "The Godfathers of 'Truth': Max Weber and Carl Schmitt in Morgenthau's Theory of Power Politics," Review of International Studies 24 (1997): 185-200; Hans J. Morgenthau, "Fragment of an Intellectual Autobiography: 1904- 
Beyond his critique of rationalism, Morgenthau also offers a political theological diagnosis of the postwar international order that is distinctly Schmittian. He argues the world is mired in the kind of explosive conflict that it has not seen since the religious wars of medieval and early modern Europe. The political religions of the postwar period fight to end evil, annihilate their unjust enemies, and remake the world in their own images. While the memory of the secularized apocalypticism of Nazism looms heavily in the background of this diagnosis, Morgenthau focuses his attention on the Cold War confrontation between Soviet Communism and American liberal internationalism, with overwhelming critical attention devoted to the latter. At its most extreme, liberal internationalism sees a devastating final war for a singular "humanity" as a necessary prerequisite to a millennial democratic future. This kind of apocalyptic ideology, combined with a return to total war and the potential for large-scale nuclear annihilation, make the secularized eschatologies of the twentieth century even more dangerous than their religious predecessors. The postwar world, Morgenthau fears, seems headed for another total war which "may end in world dominion or in world destruction or in both." 63

This situation is the result of the almost complete dissolution of a Western intellectual and moral consensus that emerged at the end of the Thirty Years' War with the Peace of Westphalia and the beginning of the modern state system. In order to understand Morgenthau's diagnosis of the twentieth century, one must therefore grasp the general outlines of his much larger macro-historical narrative. Before outlining this narrative, however, it is worth noting that Morgenthau is no historian. He proceeds in broad strokes and offers a presentation of empirical evidence that is at best highly selective and at worst willfully blind to established historical facts.

1932," in Truth and Tragedy: A Tribute to Hans J. Morgenthau, eds. Kenneth Thompson and Robert J. Myers (New Brunswick: Transaction Books, 1984), 15-16.

${ }^{63}$ Hans J. Morgenthau, "World Politics in the Mid-Twentieth Century," The Review of Politics 10, no. 2 (April, 1948), 172-3. Parts of this essay are reproduced in chps. 20-22 of Morgenthau's Politics Among Nations ( $2^{\text {nd }}$ edition, 1954). When dealing with material that appears in both texts, I will only cite the original article. 
His goal, however, is not to offer an accurate account of the inter-state conflict from the medieval period to the twentieth century, but to deploy a macro-historical narrative in the service of a polemical diagnosis of the postwar international order.

Morgenthau argues that in antiquity and the Middle Ages, war was total and "whole populations faced each other as personal enemies." ${ }^{94}$ Participants in the religious wars from the Crusades through the early seventeenth century were animated by an unwavering sense of the justice of their cause and the need to annihilate their unjust and evil foes. In such a situation, there can be no meaningful limits on either the tactics or targets of violence. One must either force one's enemies to submit to one's own worldview or annihilate them altogether. ${ }^{65}$ Morgenthau's argument here is spotty and underdeveloped. Much of it has to be inferred from the comparisons he makes between religious wars and the secular crusades of the twentieth century. ${ }^{66}$ However, here as elsewhere, his point becomes clearer if we acknowledge the ways in which it selectively redeploys an argument first made by Schmitt. Schmitt argues that the theological notion of a Just War turned the conflicts of the Middle Ages and the creedal wars of the sixteenth and seventeenth centuries into total wars. Instead of limiting the tactics and targets of violence, the doctrine of Just War encouraged each side to see the other as "unjust" and therefore the legitimate target of complete annihilation. ${ }^{67}$ Morgenthau appears to be making a similar point when he argues that in the pre-Westphalian era, "belligerents were held to be free,

\footnotetext{
${ }_{64}^{64}$ Morgenthau, "Twilight,” 85.

${ }^{65}$ This picture of warfare in Europe during the Middle Ages, along with the more detailed one that Schmitt offers, is an example of the kind of problematic presentation of history that I flagged above. To be sure, there were a few examples of the kinds of conflicts Morgenthau describes - the slaughter of Muslims in Palestine by Crusaders (1095-1099, 1147-1149, 1187-1192), attacks on Jews in the Rhineland by the same Crusaders (1096), the Albigensian Crusade against the Cathars in southern France (1209-1229), and some episodes during the religious wars between the mid-sixteenth and mid-seventeenth centuries. While these incidents are significant, they hardly amount to an accurate general characterization of the nature of medieval warfare. I am grateful to John Najemy alerting me to these examples.

${ }^{66}$ See, for example: Morgenthau, "Twilight," 85-7.

${ }^{67}$ Carl Schmitt, The Nomos of the Earth in the International Law of the Jus Publicum Europaeum, trans. G.J. Ulmen
} (New York: Telos Press, 2003), 141-2. 
according to ethics as well as law, to kill all enemies regardless of whether or not they were members of the armed forces, or else to treat them in any way they saw fit." ${ }^{68}$

For both Morgenthau and Schmitt, the 1648 Peace of Westphalia that brought the Thirty Years' War to an end marks a decisive turning point and the beginning of a new era of European international politics to which both thinkers look back with unapologetic nostalgia. ${ }^{69}$ By 1648 , "sovereignty as supreme power over a certain territory was a political fact, signifying the victory of the territorial princes over the universal authority of Emperor and Pope, on the one hand, and over the particularistic aspirations of the feudal barons, on the other."70 At this point, argues Morgenthau, individual citizens found that only their sovereigns could issue and enforce orders.

\footnotetext{
${ }^{68}$ Morgenthau's only evidence on this point is Grotius' catalog of war atrocities in Chapter 4, Book III of Hugo Grotius' On the Law of War and Peace. See: Morgenthau, "Twilight," 82, 82-3. However, this passage does help to explain a worry that Morgenthau shares with Schmitt: that the twentieth-century revival of the medieval doctrine of Just War in secular liberal garb provides the precondition for total wars of annihilation. See: Hans J. Morgenthau, Politics Among Nations: The Struggle for Power and Peace, $2^{\text {nd }}$ edition (New York: Knopf, 1954), 343; Morgenthau, "Twilight," 87, 97; Schmitt, Nomos, 259-80.

${ }^{69}$ Morgenthau and Schmitt's construction of the Peace of Westphalia as an historical turning point that fundamentally reordered both the structural and normative foundations of international politics is now widely recognized as a myth that does not withstand historical scrutiny. On historical grounds, this account makes at least two significant errors. First, it imputes to the two treaties that comprise the Peace of Westphalia doctrines that are to be found nowhere in the documents themselves. The treaties do not confirm the "sovereignty" or independence of the signatories, nor do they articulate any general principle of sovereignty. See: Andreas Osiander, "Sovereignty, International Relations, and the Westphalian Myth," International Organization 55, no. 2 (2001): 260-8. Second, the traditional account of the Peace of Westphalia fails to acknowledge the gradual nature of the development of the modern state system. In fact, modern states of the kind envisioned in the traditional account did not even begin to emerge until the eighteenth century. Before then, the European "state system" was comprised of "dynastic and other pre-modern communities." According to Benno Teschke's detailed historical work, this situation only began to change when the rise of modern capitalism and British power prompted the institutional revolutions that would lead to what we now recognize as modern European statehood. See: Benno Teschke, "Theorizing the Westphalian System of States: International Relations from Absolutism to Capitalism," European Journal of International Relations 8, no. 1 (2002): 6, 30-8. In addition, state sovereignty and the associated norm of non-intervention have consistently been violated. As Stephen Krasner summarizes, "Neither Westphalian nor international legal sovereignty has ever been a stable equilibrium from which rulers had no incentives to deviate. Rather, Westphalian and international legal sovereignty are best understood as examples of organized hypocrisy." See: Stephen D. Krasner, Sovereignty: Organized Hypocrisy (Princeton: Princeton University Press, 1999), 24. However, Morgenthau's conventional presentation of the Westphalian story was not unusual for its time. In the same year that he published his own extensive treatment on sovereignty, Leo Gross released his immensely influential article "The Peace of Westphalia: 1648-1948," American Journal of International Law 42, no. 1 (1948): 20-41. Here, Gross proclaimed that the Peace of Westphalia "represents the majestic portal which leads from the old into the new world" (28). On the influence of Gross' article in International Relations, see: Osiander, "Sovereignty, International Relations," 264-6.

${ }^{70}$ Hans J. Morgenthau, “The Problem of Sovereignty Reconsidered," Columbia Law Review 48, no. 3 (1948): 341. Parts of this essay are reproduced in ch. 19 of Morgenthau's Politics Among Nations ( $2^{\text {nd }}$ edition, 1954). When dealing with material that appears in both texts, I will only cite the original article.
} 
Sovereigns found that they could not exert authority within the territory of other states without first obtaining permission from their sovereign counterpart or by defeating them in war. The doctrine of sovereignty elevated these facts into a legal theory. The individual sovereign was the "sole source of man-made law, that is, of all positive law, but was not himself subject to it.","11 The independence of these sovereign states was maintained by a Western tradition that "imposed moral and legal limitations on struggle for power on the international scene and...maintained order in the international community." ${ }^{72}$ For Morgenthau, this supranational moral consensus was explicitly Eurocentric and aristocratic. That is, it was a consensus among princes, aristocratic rulers, and high-level diplomats, who were connected with their counterparts in other states "through family ties, a common language (which was French), common cultural values, a common style of life, and common moral convictions as to what a gentleman was and was not allowed to do in his relations with another gentleman, whether of his own or of a foreign nation." ${ }^{, 73}$ As sovereigns jostled for power on the international stage, they did so "as competitors in a game whose rules were accepted by all the other competitors." ${ }^{74}$ In contrast to the participants in creedal wars, an aristocratic member of the modern state system would not even consider imposing his own particularistic conception of justice on others. In fact, "the very

\footnotetext{
${ }^{71}$ Morgenthau, "Problem of Sovereignty," 341. As Nicolas Guilhot notes, Morgenthau's point here is related to Schmitt's proclamation: "Sovereign is he who decides on the exception." See: Carl Schmitt, Political Theology: Four Chapters on the Concept of Sovereignty, trans. George Schwab (Chicago: University of Chicago Press, 1985), 5; Guilhot, "American Katechon," 240.

${ }_{72}^{72}$ Morgenthau, "World Politics," 154.

${ }^{73}$ Morgenthau, "Twilight," 88.

${ }^{74}$ Morgenthau, "Twilight," 88. Schmitt makes a similar point when he argues that the rise of the sovereign state made international conflict in Europe analogous in most respects to a duel. The justice of a duel is not determined by assessing whether one side or another has a "just cause." Rather, a duel is just when "there are certain guarantees in the preservation of the form - the quality of the parties to the conflict as agents, in the adherence to a specific procedure... and, especially, in the inclusion of witnesses on equal footing...A challenge to a duel (défi) was neither aggression nor a crime, any more than was a declaration of war." See: Schmitt, Nomos, 143. As a member of a German dueling fraternity during his early twenties, Morgenthau might have particularly appreciated this analogy.
} 
possibility of such an aspiration never occurred to them, since they were aware only of one universal moral code to which they all gave unquestioning allegiance."75

For Morgenthau, as for Schmitt, the most important effect of this supranational moral consensus was that it placed limits on international conflict, effectively humanizing warfare. Once enemies were no longer seen as evil foes to be annihilated, war began to be seen not as "a contest between whole populations but only between the armies of belligerent states."76 This shift in the understanding of international war gave rise to the distinction between combatants and non-combatants, prohibited and limited the use of particularly destructive weapons, and restricted "the use of war as an instrument of international politics."77 For Morgenthau, these moral limitations arose gradually and came to full fruition in a series of international treaties and conventions of the nineteenth and early twentieth centuries. ${ }^{78}$ The Hague Protocols and the Geneva Convention, for instance, attest to "the existence of a moral conscience which feels ill at ease in presence of violence or, at least, certain kinds of it on the international scene."79

Beyond the legal codification of these moral limits, Morgenthau finds further evidence of a supranational consensus in patterns of state behavior. He considers the 'hard case' of Otto von

\footnotetext{
${ }^{75}$ Morgenthau, "Twilight," 98. For Morgenthau, this moral code is only "universal" within the European state system. In fact, the expansion of the colonial frontier provided an outlet for state ambitions, thereby helping states to maintain the "universal moral code" among their European partners. In fact, Morgenthau attributes the decline of the nineteenth-century international system, along with the normative consensus that sustained it, in part to the disappearance of the colonial frontier. See: Morgenthau, "World Politics," 164-8. Schmitt makes a similar argument about the European nomos (or set of international ordering principles). This Eurocentrism is the condition of possibility for their shared nostalgia. They do not have to seriously consider, for example, the extermination of indigenous peoples and the enslavement of Africans by Europeans and Euro-Americans that occurred during this period.

${ }_{77}^{76}$ Morgenthau, "Twilight," 83.

${ }^{77}$ Morgenthau, "Twilight," 84-5.

${ }^{78}$ This is one of the places where Morgenthau's argument differs sharply from Schmitt's. For Schmitt, the Peace of Westphalia marked the rise of the modern territorial state and a secular European nomos, which served to "bracket" war between European states. While Schmitt did see cultural homogeneity as an important precondition for this nomos, he would have resisted the idea that a universal code (particularly one codified in the international treaties of the nineteenth and early twentieth centuries, which Schmitt sees as a symptom of the dissolution of the European nomos) provided the basis for the limited war of Europe's "golden age." See: Brown, "The Twilight," 51.

${ }^{79}$ Morgenthau, "Twilight," 84.
} 
Bismarck, whose "moves on the chessboard of international politics" in nineteenth-century Europe were "ruthless and immoral." Yet even Bismarck "rarely deviated from the basic rules of the game which had prevailed in the society of Christian princes of the eighteenth century. It was a fraudulent and treacherous game, but there were a few things that no member of that aristocratic society would stoop to do. ${ }^{, 80}$ Bismarck, for instance, could never have contemplated the possibility of annihilating Germany's eastern and western neighbors. The fact that Hitler was able to imagine and deploy such a strategy is a symptom of the dissolution of the supranational moral consensus that had previously restrained even the most ambitious states. In a paradoxical and idiosyncratic move, Morgenthau is suggesting that the naked and seemingly amoral practice of international politics in the nineteenth century was actually made possible by an underlying supranational moral consensus. What allowed the "fraudulent and treacherous game" of European politics to operate was the fact that the supranational moral consensus prevented skirmishes and power grabs from erupting into full-scale campaigns of annihilation.

Morgenthau attributes the unraveling of this consensus to two developments: "the substitution of democratic for aristocratic responsibility in foreign affairs and the substitution of nationalistic standards of action for universal ones. ${ }^{״ 11}$ The end of the nineteenth century marked a shift toward democratic selection of officials responsible for foreign affairs in European states. These officials were now "legally and morally responsible for their acts, not to a monarch, that is, a specific individual, but to a collectivity, that is, a parliamentary majority, or the people as a whole." 82 This shift had three consequences. First, officials were no longer recruited exclusively from the ranks of the aristocracy, but from a much broader cross-section of the population. They could no longer be expected to share a supranational moral consensus

\footnotetext{
${ }^{80}$ Morgenthau, "Twilight," 81.

${ }^{81}$ Morgenthau, "Twilight," 81.

${ }^{82}$ Morgenthau, "Twilight," 91.
} 
premised on codes of gentlemanly conduct. Second, regular elections caused frequent turnover of government officials. The lasting personal and cultural ties that held the supranational consensus together evaporated. Finally, and most importantly, the persistent need to appeal to an electorate with diverse moral positions made the possibility of a supranational consensus impossible. Individual voters "may have no moral convictions of a supranational character at all which determine their actions on election day...or, if they have such convictions, they will be most heterogeneous in content." ${ }^{83}$ In this cacophony of diverse moral commitments, “international morality as an effective system of restraints on international policy becomes impossible." 84 The consensus that had held the Westphalian European state system together was torn apart by democracy and pluralism.

The second development that Morgenthau holds responsible for the unraveling of this consensus - "the substitution of national standards of action for universal ones"-is, in my reading, less a cause than a consequence of this unraveling. Morgenthau explains that in the absence of a cohesive and aristocratic international society, the community of Western states fragmented into a plurality of national communities with their own particular moral ideals, each claiming universal validity. ${ }^{85}$ Nations became both the supreme principle of collective organization and the ultimate repositories of moral allegiances. ${ }^{86}$ To be sure, the nineteenth-

\footnotetext{
${ }^{83}$ Morgenthau, "Twilight," 92.

${ }^{84}$ Morgenthau, "Twilight," 91.

${ }^{85}$ Morgenthau, "Twilight," 95.

${ }^{86}$ Morgenthau, "World Politics," 154. At this point in Morgenthau's argument, a careful reader might well ask: Why would individuals with the diversity and plurality of moral commitments that made a supranational consensus impossible in a democratic age be willing to commit themselves to the moral consensus required by nationalism? This is not a question to which Morgenthau provides an adequate answer. He argues that the individual recognizes that he lives in an age in which universal moral standards cannot effectively restrain state action. States flout these universal standards and the individual's conscience is "ill at ease." Unable to give up on the idea of a universal ethics, "he pours, as it were, the contents of his national ethics into the now almost empty bottle of universal ethics." While this argument may explain the way in which an individual comes to substitute the moral standards of his own nation for the universal standards of a dying supranational consensus, it does not explain how nationalism is able to overcome the plurality of moral commitments that had posed such difficulties for the continued viability of an international society. See: Morgenthau, "Twilight," 96.
} 
century golden age to which Morgenthau looks back with unapologetic nostalgia had its fair share of nationalism. However, nineteenth-century nationalism had the more limited goal of national liberation. ${ }^{87}$ The nation itself was "the ultimate goal of political action, the end-point of the political development beyond which there are other nationalisms with similar goals and similar justifications." ${ }^{88}$ In contrast, the twentieth-century "nationalistic universalisms" of German Nazism, Soviet Communism, and American liberal internationalism see the nation as "but the starting-point of a universal mission whose ultimate goal reaches to the confines of the political world. ${ }^{\$ 9}$ Foreign policies became sacred missions and wars became crusades waged "for the purpose of bringing the true political religion to the rest of the world." 90 Morgenthau's characterization of the phenomenon of nationalistic universalism is striking and worth quoting at length:

[Nations] oppose each other now as the standard-bearers of ethical systems, each of them of national origin and each of them claiming and aspiring to provide a supranational framework of moral standards which all the other nations ought to accept and within which their international policies ought to operate. The moral code of one nation flings the challenge of its universal claim in the face of another which reciprocates in kind. Compromise, the virtue of the old diplomacy, becomes the treason of the new...Thus, the stage is set for a contest among nations whose stakes are no longer their relative positions within a political and moral world accepted by all but the ability to impose upon the other contestants a new universal political and moral system recreated in the image of the victorious nation's political and moral commitments. ${ }^{91}$

The international system is no longer a chessboard on which monarchs and aristocrats seek to improve their relative positions. It is an unlimited war between nationalist political religions with false claims to universality.

\footnotetext{
${ }^{87}$ Morgenthau, "World Politics," 155.

${ }^{88}$ Morgenthau, "World Politics," 156.

${ }^{89}$ Morgenthau, "World Politics," 156.

${ }^{90}$ Morgenthau, Politics Among Nations, 98.

${ }^{91}$ Morgenthau, "Twilight," 96-7.
} 
What becomes clear at this point is that Morgenthau is not simply criticizing the pseudoreligious tendencies of nationalistic universalism, but also the process of secularization that provides their condition of possibility. ${ }^{92}$ The supranational consensus that had created a genuine "society" of European states was not just moral. It was also religious. The rules that constrained Bismarck in the nineteenth century were the same ones that "had prevailed in the society of Christian princes of the eighteenth century." 93 The supranational consensus was composed of "Christian, cosmopolitan, and humanitarian elements" and the international society that this moral agreement created "had united the monarchs and the nobility of Christendom." 94 The instability of the twentieth century became permanent "as a result of the weakening of the ties of the [Western] tradition, especially in the form of religion." 95 The nationalist pseudo-religions of the twentieth century are therefore the products not only of the weakening of supranational ethical standards but also of secularization. ${ }^{96}$ Invoking Hobbes, Morgenthau notes: "The state has indeed become a 'mortal God,' and for an age that believes no longer in an immortal God, the state becomes the only God there is." 97

\footnotetext{
${ }^{92}$ This dimension of Morgenthau's thought has received very little attention in the secondary literature, which tends to ignore the political theological features of his work. Nicolas Guilhot's work is a notable exception and my argument here borrows from the interpretation he offers in "American Katechon," 242-3.

${ }^{93}$ Morgenthau, "Twilight," 81. Emphasis mine.

${ }^{94}$ Morgenthau, "Twilight," 95, 93. Emphasis mine.

${ }^{95}$ Morgenthau, Politics Among Nations, 98. Emphasis mine.

${ }^{96}$ These are the moments in Morgenthau's argument where he comes closest to overtly endorsing Schmitt's secularization thesis. For Schmitt, the combination of the depoliticizing tendencies of the liberal state and the separation of the political from the religious creates the conditions of possibility for a "mass belief in an antireligious activism... the belief in unlimited power and the domination of man over nature, even over human nature; the belief in the 'receding of natural boundaries,' in the unlimited possibilities for change and prosperity. Such a belief can be called fantastic and satanic, but not simply dead, spiritless, or mechanized soullessness." See: Carl Schmitt, "The Age of Neutralizations and Depoliticizations" (1929), in The Concept of the Political, trans. by George Schwab (Chicago: University of Chicago Press, 2007), 94. However, as Guilhot explains, "Schmitt does not advocate a re-theologization of politics; rather, he defends the autonomy of the political, but also warns that this autonomy is premised on the historical constitution of a territorial order distinct from, but coexisting with, the moral order embodied by the ecclesial institutions of Christianity. Should secularization proceed to the extent that the state no longer understands itself in relation to (and in tension with) this background and conflates its own interests with morality itself - as in the case of liberalism - then it would assume again religious attributes and give rise to dangerous political religions.” See: Guilhot, “American Katechon,” 234.

${ }^{97}$ Hans J. Morgenthau, "The Evil of Politics and the Ethics of Evil," Ethics 56, no. 1 (1945): 15.
} 
In the golden era of the European state system, universal religion had been tamedtransformed from the enabling condition of wars of annihilation to part of the background consensus that curbed the worst excesses of power politics. The pseudo-religions of the twentieth century drive the world back to wars of annihilation aimed at the eradication of evil. The nationalistic masses of the twentieth century meet "carrying their idols before them...each group convinced that it executes the mandate of history, that it does for humanity what it seems to do for itself, and that it fulfils a sacred mission ordained by providence, however defined. Little do they know that they meet under an empty sky from which the gods have departed." 98 The destructive nationalism of the twentieth century is a symptom and product of secularization.

The three most powerful nationalistic universalisms of Morgenthau's day are German Nazism, Soviet Communism, and American liberal internationalism. Indeed, he dates the ultimate destruction of the supranational moral consensus that had prevailed since 1648 to the rise of the Nazis in $1933 .{ }^{99}$ For him, the secularized religious elements of Nazism were quite clear: "It has in Hitler its savior, in S.A., S.S., and party its sacred orders, in Mein Kampf its bible, in the immutable twenty-five points of the party program its catechism, in the racial community its mystical body. It has its miracles and rituals, its apostles, martyrs, and saints."100 At its heart is an apocalyptic dualism in which "the German race is on the side of the angels, and the Jews and other 'racial degenerates' are on the side of the devil; and once the problem is posed in such terms, the solution presents no intellectual or physical difficulties."101 The

\footnotetext{
${ }^{98}$ Morgenthau, "Twilight," 99.

${ }^{99}$ Morgenthau, Politics Among Nations, 200. William Scheuerman points to this as another point of divergence between the narratives of decline offered by Morgenthau and Schmitt. For Morgenthau, 1933 marks the complete demolition of the supranational moral consensus that underpinned the Westphalian state system. For Schmitt, the Nazis were "trying to build on the best elements of the traditional international system while warding off its real foe- the United States." See: Scheuerman, "Carl Schmitt and Hans Morgenthau," 89 (fn 23).

${ }^{100}$ Hans J. Morgenthau, "Naziism" (1946), in The Decline of Democratic Politics (Chicago: University of Chicago Press, 1962), 228.

${ }^{101}$ Morgenthau, "Naziism," 235.
} 
solution is the elimination of evil through a program of mass extermination and worldwide conquest of apocalyptic proportions. It is only through this transformative war that "the hidden will of nature and of racial destiny becomes manifest." ${ }^{\text {102 }}$ And, like the apocalyptic religions of the creedal wars, Nazism's "claim to acceptance is absolute and not subject to critical doubt."103 Any form of dissent is "a sacrilegious revolt against the 'voice of the blood,' through which the genius of the race makes itself known." ${ }^{104}$ Nazism's promise of worldly salvation was proven false, its prophecies unfulfilled, and its bid for universality lost with Germany's defeat in the Second World War. ${ }^{105}$ What is important, however, is that Morgenthau treats Nazism not as an aberrant or unique historical occurrence, but as a case of the broader phenomenon of an apocalyptic political religion whose aim is world transformation and domination.

Nazism's lost bid for universality left two remaining political religions whose conflicts would define the postwar world-Soviet Communism and American liberal internationalism. While Morgenthau makes occasional remarks about the pseudo-religious qualities of the former ${ }^{106}$, the overwhelming bulk of his critical attention is devoted to the latter. Like religious eschatologies, liberal internationalism has a teleological conception of history that culminates in a final battle to purge the forces of evil, ushering in a new world of peace and prosperity. However, liberal internationalism is not apocalyptic from the outset. It begins with a progressive millennial conception of history that anticipates change through gradual and peaceful

\footnotetext{
${ }^{102}$ Morgenthau, "Naziism," 240.

${ }^{103}$ Morgenthau, "Naziism," 228.

${ }^{104}$ Morgenthau, "Naziism," 238.

${ }^{105}$ Morgenthau draws a distinction on this point between genuine religions and political religions. He explains: "All political religions stand and fall with the experimental proof of their truth. In contrast, other worldly religions are based on faith. Nobody has come back from the other world and told us whether the biblical description of heaven corresponds to reality. But a political religion, which pretends to bring salvation to men in this world and which...pretends that salvation is just around the corner, stands and falls with the experimental proof or the correctness of its prophecies." See: Hans J. Morgenthau, "The Tragedy of German-Jewish Liberalism" (1961), in The Decline of Democratic Politics (Chicago: University of Chicago Press, 1962), 253.

${ }^{106}$ See, for instance: Morgenthau, Scientific Man, 32-3, 52-3; Morgenthau, "Twilight," 97; Hans J. Morgenthau, In Defense of the National Interest: A Critical Examination of American Foreign Policy (New York: Knopf, 1951), 623.
} 
transformation, rather than cataclysmic violence. It expects the slow but inevitable spread of democracy to all corners of the world, bringing the benefits of education and rationalism with it. Liberal democracy overcomes the messy antagonisms of politics by replacing them with a rational and efficient plan, effectively reducing the political to the technical. ${ }^{107}$ And with democracy, education, and reason comes peace. Violent conflict is seen as "something irrational, unreasonable, an aristocratic pastime or totalitarian atavism which has no place in a rational world. War is essentially a thing of the past." ${ }^{, 108}$ Once reason becomes the driving force of international affairs, the causes of conflict disappear and any remaining disagreements can be settled peacefully. Because the rationalist philosophy that underpins liberalism identifies the rational with the good, we should also expect to see moral progress. The notion that there is one (more demanding) set of ethical standards for the individual and another (more permissive) set for the state will disappear. As Woodrow Wilson proclaimed in 1917: "We are the beginning of an age in which it will be insisted that the same standards of conduct and of responsibility for wrong shall be observed among nations...that are observed among the individual citizens of civilized states." ${ }^{109}$ In short, without any violent intervention, the world will march toward a more democratic, peaceful, and moral future.

Yet like other frustrated millennialist movements for whom the inevitable transformation of the world fails to materialize, liberal internationalists seek explanations for the inability of history to achieve its ends. Faced with uneven evidence of the spread of democracy or the success of international legal reforms, "the internationalists take the appropriateness of the devices for granted and blame the facts for the failure. 'When the facts behave otherwise than

\footnotetext{
${ }^{107}$ Morgenthau, Scientific Man, 27-37. Morgenthau's concerns here mirror Schmitt's that liberalism reduces politics to technology. See: Carl Schmitt, "Neutralizations and Depoliticizations," 80-96.

${ }^{108}$ Morgenthau, Scientific Man, 47.

${ }^{109}$ As quoted in Morgenthau, Scientific Man, 44. This identity of the individual and the state is also central to international law.
} 
we have predicted,' they seem to say, 'too bad for the facts.",110 The obstacles to liberal internationalist projects are not the schemes themselves or the belief in human perfectibility upon which they are based, but rather "lack of knowledge and understanding, obsolescent social institutions, or the depravity of certain isolated individuals or groups." 111 The failure to overcome the irrationality of war with a democratic peace is blamed on totalitarian and aristocratic states, or evil and criminal nations who disrupt the normalcy of "peaceful competition and cooperation."112

For Morgenthau, this turns the conflicts of the postwar era into battles of good versus evil. In contrast to the "selfless and moral" foreign policies of the United States, "the foreign policies of other nations are by definition selfish and immoral. Since the United States is the policeman of the world seeking only peace and order and the welfare of all, only evil nations can dare oppose it. They are criminals when they act alone, conspirators when they act in unison."113 And if criminals cannot be made peaceful through education and reform, "they must be converted with fire and sword." ${ }^{114}$ Liberal idealism thus falls victim to the same dangers as medieval Just War thinking. The moral limits on war that were crystallized in the international treaties of the nineteenth and early twentieth centuries become meaningless. When confronting an unjust foe, "the moral duty to spare the wounded, the sick, the surrendering and unarmed enemy, and to respect him as a human being who was an enemy only by virtue of being found on the other side of the fence is superseded by the moral duty to punish and to wipe off the face of

\footnotetext{
${ }^{110}$ Morgenthau, Scientific Man, 39.

111 Morgenthau, Politics Among Nations, 3.

${ }^{112}$ Hans J. Morgenthau, In Defense of the National Interest: A Critical Examination of American Foreign Policy (New York: Knopf, 1951), 93, 95. See also: Morgenthau, Scientific Man, 51.

${ }_{113}$ Morgenthau, National Interest, 93.

${ }^{114}$ Morgenthau, National Interest, 37.
} 
the earth the professors and practitioners of evil."115 Convinced that they have justice on their side, liberal internationalists will fight total wars which can only end in the annihilation or "unconditional surrender" of the unjust enemy.

Given their abhorrence of war, liberal internationalists justify these battles by investing them with apocalyptic significance. This is what Woodrow Wilson did when he announced to America and the world in 1918 that the Great War would be "the final and culminating war for human liberty." For Morgenthau, these slogans are not propaganda meant to conceal the base power interests of the United States. Rather, "they are the expression of an eschatological hope deeply embedded in the very foundations of liberal foreign policy."116 That hope is for a world transformation through a final and decisive battle against the irrational forces of evil. The promise of such a battle, as well as the grounds for its moral justification, is that it is the necessary prerequisite for a permanent peace. The liberal millennium is "a brave new world" in which states do not engage in power politics and where the concept of a national interest becomes meaningless in a "community of interests comprising mankind." ${ }^{117}$ For Morgenthau, who conceptualizes politics as a particularly intense form of antagonism and conflict, the liberal millennium amounts to nothing less than "the repudiation of politics."118 It is a dangerous apocalyptic fantasy that takes aim at both the desire for power that inheres in individuals and the

\footnotetext{
${ }^{115}$ Morgenthau, "Twilight," 87. Morgenthau thought he saw evidence for this shift in World War II, where the violation of these moral limits is "a matter of fact."

${ }^{116}$ Morgenthau, Scientific Man, 52.

${ }^{117}$ Morgenthau, National Interest, 26. Morgenthau's use of overtly eschatological language is indisputable. He titles a section on utopianism "After the War-The Millennium" in In Defense of the National Interest, 92.

${ }^{118}$ Morgenthau, Scientific Man, 41. Morgenthau's understanding of the political is strikingly similar to that of Schmitt. However, in this case, the direction of influence is reversed. There is good evidence that Schmitt changed his understanding of the political as a result of Morgenthau's criticisms. William Scheuerman summarizes the evidence well. The first edition of Schmitt's Concept of the Political had conceptualized "the political as constituting a fundamentally distinct and independent sphere of activity, existing alongside alternative modes of human activity." For Morgenthau, the political denoted a particularly intense form of conflict and antagonism. Thus, any sphere of human activity could become political if it became the site of intense conflict. In response to Morgenthau's criticisms, the second edition of the Concept of the Political "dropped the misleading imagery of politics as a distinct or separate sphere, instead following Morgenthau's conceptualization of politics as concerning conflicts characterized by intense enmity.”S See: Scheuerman, Hans Morgenthau, 33.
} 
international manifestation of this desire in the pursuit of national interests. Because these desires are unchanging, liberal wars can never be "last wars." Instead, like World War I, they will merely be "the forerunners and pioneers of wars more destructive and extensive than any liberal epoch had witnessed." ${ }^{119}$ This possibility loomed large over the postwar world, in which American liberal internationalism had met its crusading foe in Soviet Communism and both had found in nuclear weapons the means to match their totalizing ends.

Like Machiavelli, Morgenthau's response to the apocalyptic political religions of his time is a turn to tragedy. While this turn pervades much of his work from the 1940s and 1950s, Morgenthau's clearest articulation of the tragic worldview is in the final chapter of Scientific Man versus Power Politics (1946). Here, he aims to recover a "tragic sense of life" that has been lost in the modern era. At the root of a tragic worldview is "the awareness of unresolvable discord, contradictions, and conflicts which are inherent in the nature of things and which human reason is powerless to solve." ${ }^{120}$ Morgenthau's turn to tragedy is often read as a critique of the scientism and rationalism that underpins the liberal tradition. ${ }^{121}$ There is certainly ample textual evidence to support this interpretation. However, it does not exhaust the possibilities of Morgenthau's tragic worldview. In the foregoing analysis, I have drawn out the politicaltheological dimensions of Morgenthau's portrait of a crusading liberalism. I suggest here that his turn to tragedy offers a response and alternative to liberal internationalism's apocalyptic imaginary.

Against the teleology of the liberal millennial and apocalyptic narratives, Morgenthau offers a tragic and cyclical conception of time. The fortunes of states and men rise and decline in

\footnotetext{
${ }^{119}$ Morgenthau, Scientific Man, 67.

${ }^{120}$ Morgenthau, Scientific Man, 206.

${ }^{121}$ Richard Ned Lebow, The tragic vision of politics: Ethics, interests and orders (Cambridge: Cambridge University Press, 2003), 48-9, 308; Frei, Hans J. Morgenthau, 85-89.
} 
an "everlasting and ever undecided struggle" with no hope for a settled end to political conflict. $^{122}$ Here, Morgenthau could have looked to classical Greek tragic narratives or to the rich German revival of tragedy in the work of Friedrich Nietzsche and Max Weber, among others. ${ }^{123}$ He does not. Instead, he draws on the Christian pre-rationalist tradition of Duns Scotus, Augustine, Thomas Aquinas, and Martin Luther, all of whom acknowledge that "the sinfulness of man is...not an accidental disturbance of the order of the world sure to be overcome by a gradual development toward the good but...an inescapable necessity which gives meaning to the existence of man and which only an act of grace and salvation is able to overcome." 124 Morgenthau's appeal to a language of sin and salvation is taken by some interpreters to be a means of concealing the German origins of his ideas for an American audience only beginning to recover from World War II. ${ }^{125}$ However, the deployment of this Christian pre-rationalist tradition allows Morgenthau to make an important anti-apocalyptic move. He asserts: "There is no progress toward the good, noticeable from year to year, but undecided conflict which sees today good, tomorrow evil, prevail; and only at the end of time, immeasurably removed from the here and now of our earthly life, the ultimate triumph of the forces of goodness and light will be assured."126 Morgenthau borrows from the conservative eschatology of Augustine and locates the apocalyptic triumph of good over evil in an unforeseeable future. When and if it ever happens, this triumph will come in the form of a divine act, not as the product of human agency. In the secular world of the here and now, history offers no hope for a final and settled end to

\footnotetext{
${ }^{122}$ Morgenthau, Scientific Man, 206.

${ }^{123}$ We know that Morgenthau was reading Nietzsche as he completed Scientific Man vs. Power Politics. He wrote to the head of the University of Chicago library and alerted them to the fact that they had only single volumes of some of Nietzsche's most “indispensable works." See: Frei, Hans J. Morgenthau, 188.

${ }^{124}$ Morgenthau, Scientific Man, 204.

${ }^{125}$ Frei, Hans J. Morgenthau, 189. For a similar argument about other aspects of Morgenthau's thought, see: Guilhot, "American Katechon," 240-7.

${ }^{126}$ Morgenthau, Scientific Man, 205-6. Emphasis mine.
} 
conflict. The best one can hope for is to be "passed by for a time by the stream of events" in a tragic drama played out again and again. ${ }^{127}$

Morgenthau argues that any human project that aims to create a final and just peace ignores the tragic limits to political action. The effects of our actions always escape our intentions. There are three reasons for this. First, we are all caught between our higher moral and spiritual aspirations, on the one hand, and our animal drive to dominate, on the other. As a result, man "is forever condemned to experience the contrast between the longings of his mind and his actual condition as his personal, eminently human tragedy."128 While the age of science offers the promise of engineering "a new man whose powers equal his aspirations and who masters human destiny as he masters a machine," this promise soon reveals itself to be nothing more than "the old hybris...in the new vestments of a scientific age." 29 We are condemned to an eternal agonism between our higher aspirations and our lower drives. As a result, we will often be unable to recognize our moral intentions in our political actions. Second, even if we can temporarily master our urge to dominate others, we are unable to control and anticipate the worldly effects of our deeds. Once performed, an action collides with other actions and provokes responses, leading to consequences that we could never have foreseen and have only a

\footnotetext{
${ }^{127}$ Morgenthau, National Interest, 92.

${ }^{128}$ Morgenthau, Scientific Man, 221. Machiavelli makes a seemingly similar point when he argues that "since from nature [men] have the ability and the wish to desire all things and from fortune the ability to achieve few of them, there continually results from this a discontent in human minds..." See: Niccolò Machiavelli, Discourses on Livy, trans. Harvey C. Mansfield and Nathan Tarcov (Chicago: University of Chicago Press, 1996), preface to Book II, 125. However, for Morgenthau the crucial contrast is between the moral or spiritual "longings of the mind" and our capacity to fulfill them, given our animal drive to dominate. For Machiavelli, the crucial contrast is between man's natural insatiable appetites and his capacity to achieve them, given the limits imposed by fortune. Here, then, Morgenthau's tragic vision seems to share more with Paul than Machiavelli. For Paul, there is a tragic conflict between our intentions and our actions: "For I do not do the good I want, but the evil I do not want is what I do... So then, with my mind I am a slave to the law of God, but with my flesh I am a slave to the law of sin." See: Rom. $7: 19,25$.

${ }^{129}$ Morgenthau, Scientific Man, 221, 222.
} 
limited capacity to control. These collisions "deflect the action from its intended goal and create evil results of our intentions." 130

Third, our best intentions may be corrupted even before they are translated into actions. The world confronts us with tragic choices between equally legitimate ends. The necessity of making a choice means that our actions are never wholly good. In pursuing one moral end, we inevitably abandon another. Morgenthau confronts us with the familiar example of the conflict between our religious and secular duties: "While trying to render to Caesar what is Caesar's and to God what is God's, we will at best strike a precarious balance which will ever waver between both, never completely satisfying either." ${ }^{\prime 131}$ These kinds of conflicts are particularly pronounced in politics, where the connections of the self to others through action multiply. For Morgenthau, as for Machiavelli, the best statesmen are those who recognize these tragic conflicts and still manage to act:

To know with despair that the political act is inevitably evil, and to act nevertheless, is moral courage. To choose among several expedient actions the least evil one is moral judgment. In the combination of political wisdom, moral courage, and moral judgment, man reconciles his political nature with his moral destiny. That this conciliation is nothing more than a modus vivendi, uneasy, precarious, and even paradoxical, can disappoint only those who prefer to gloss over and to distort the tragic contradictions of human existence with the soothing logic of specious concord. ${ }^{132}$

These precarious and temporary conciliations are the best that we can hope for in a tragic world.

The expectation of a final overcoming of this modus vivendi is a dangerous illusion premised on the desire to escape from the moral conflict and struggle of the political condition.

\footnotetext{
${ }^{130}$ Morgenthau, Scientific Man, 189.

${ }^{131}$ Morgenthau, Scientific Man, 190.

${ }^{132}$ Morgenthau, Scientific Man, 203. Machiavelli makes a similar point about expediency and moral judgment at least three times. See: Niccolò Machiavelli, The Prince, trans. Harvey C. Mansfield (Chicago: University of Chicago Press, 1998), ch. 21, 91; Machiavelli, Discourses, I.6, 22; I.38, 81-2.
} 


\section{Nuclear Death}

While this tragic worldview offers an alternative and response to the apocalyptic political religions vying for global dominion, it provides few intellectual or imaginative strategies for confronting the radical novelty of the nuclear age and the very real threat of an all-out nuclear war. Morgenthau's writings from the 1950s are marked by a struggle to come to terms with this novel threat. In the early 1960s, however, Morgenthau takes a decisive turn away from a tragic perspective and toward a Hobbesian strategy of fighting apocalypse with apocalypse. His remarkable 1961 essay "Death in the Nuclear Age" offers a terrifying account of an apocalypse without redemption or renewal. This essay, along with some of Morgenthau's other later work, marks a definitive shift away from a tragic worldview and toward a reformative attempt to imagine the apocalypse in order to prevent it.

During the late 1940s and 1950s, Morgenthau struggled to grasp the radical novelty of nuclear weapons, his position developing and changing with advances in nuclear capabilities. In 1948, he casts nuclear weapons as merely the latest stage in the mechanization of warfare. Nuclear weapons represent a development that is similar in kind, through far greater in magnitude, to the invention of the machine gun. ${ }^{133}$ Nevertheless, it is a development that, along with the crusading political religions of the twentieth century, has made total war possible. ${ }^{134}$ As he outlines in Politics Among Nations, the obvious solution to this problem is a world state that can extract loyalty from humanity as a whole, provide the "citizens" of the world with some measure of justice, and establish a "monopoly of organized violence."135 The mistake of previous advocates of international government had been to assume that such an institution could

\footnotetext{
${ }^{133}$ Hans J. Morgenthau, Politics Among Nations: The Struggle for Power and Peace (New York: Knopf, 1948), 2967.

${ }^{134}$ Morgenthau, "World Politics," 172-3.

${ }^{135}$ Morgenthau, Politics Among Nations, 395, 392-400. Interestingly, Morgenthau does not cite Max Weber here. $\mathrm{He}$ also replaces "legitimate" with "organized."
} 
be imposed from above. Just as a national state emerges from the bottom-up demands of a society, a world state would first require a world society. As Campbell Craig neatly summarizes: "for a world state to emerge, a world society would have to form, with enough power and influence to: a) persuade majorities of the world's national populations to transfer their loyalties from their own state to a world entity; b) ensure somehow that the citizens of the world state can expect justice from it; and c) then compel all of the world's states to turn over their arms to a new world entity." 136

Unfortunately, there is no escaping the fact that most people still invest their highest loyalties in the nation-state. Occasional bursts of international humanitarian assistance aside, there is little evidence of the kind of supranational society required to create a world state. Thus, Morgenthau concludes: "There is no shirking the conclusion that international peace cannot be permanent without a world state, and that a world state cannot be established under the present moral, social, and political conditions of the world." The tragedy, he goes on, is that "in no period of modern history was civilization in more need of permanent peace and, hence, of a world state, and that in no period of modern history were the moral, social, and political conditions of the world less favorable for the establishment of a world state." ${ }^{, 137}$ Morgenthau's solution is to cast the creation of a world community as a long-term goal, the first step toward which is the mitigation and minimization of the sources of conflict. He therefore concludes Politics Among Nations with a nostalgic plea for a return to the traditions and practice of nineteenth-century European diplomacy. ${ }^{138}$ This solution rests uneasily with the analysis in the

\footnotetext{
${ }^{136}$ Campbell Craig, Glimmer of a New Leviathan: Total War in the Realism of Niebuhr, Morgenthau, and Waltz (New York: Columbia University Press, 2003), 66.

${ }^{137}$ Morgenthau, Politics Among Nations (1948), 402.

${ }^{138}$ Morgenthau, Politics Among Nations (1948), 419-45. Morgenthau himself seems to recognize that this solution is anachronistic. He writes: "Diplomacy is the best means of preserving peace which a society of sovereign nations has to offer, but, especially under the conditions of modern world politics and of modern war, it is not good enough" (445).
} 
rest of this work. In a world marked by the erosion of the supranational consensus that made nineteenth-century diplomacy possible, a return to the past is impossible. ${ }^{139}$ In the shadow of the atomic bomb, Morgenthau's prescriptions seemed to assume a world that no longer existed.

During the 1950s, Morgenthau acknowledged the novelty of nuclear weapons, while still clinging to conventional solutions. For him, the successful Soviet test of an atomic bomb in 1949 was "an event of the greatest importance. In comparison with it, all the great issues of the postwar period fade into insignificance." ${ }^{, 140}$ His response to this frightening news was a demand for massive and rapid American rearmament and almost unqualified support for the development of the hydrogen bomb. ${ }^{141}$ Morgenthau responded with similar alarm in the aftermath of the 1957 Soviet satellite launches, urging both a conventional weapons build-up and the direction of the "total resources of the nation toward achieving an operational ICBM at the earliest possible moment." ${ }^{142}$ In response to the novel problems posed by nuclear weapons, Morgenthau still seemed to be responding with rather conventional pleas for the restoration of the balance of power between the United States and the Soviet Union.

Yet lurking behind these prescriptions was a growing suspicion that conventional responses would not be sufficient. For instance, while he acknowledges that nuclear deterrence could be "a force for peace, however precarious," ${ }^{143}$ Morgenthau worries that the psychology of deterrence is dangerously complex and vulnerable to disastrous miscalculations. ${ }^{144}$ Similarly, while he urges the United States to prepare for and be willing to fight a limited nuclear war, he

\footnotetext{
${ }^{139}$ As one of Morgenthau's contemporary critics notes, "such a return to diplomacy is impossible without...the repeal of the nineteenth and twentieth centuries." See: James P. Speer II, "Hans Morgenthau and the World State," World Politics 20, no. 2 (1968): 222.

${ }^{140}$ Morgenthau, National Interest, 174.

${ }^{141}$ Morgenthau, National Interest, 178-80; Hans J. Morgenthau, “The H-Bomb and After" (1950), in The Restoration of American Politics (Chicago: University of Chicago Press, 1962), 119-27.

${ }^{142}$ Hans J. Morgenthau, "Russian Technology and American Policy," Current History 34, no. 119 (1958): 132.

${ }^{143}$ Hans J. Morgenthau, "Has Atomic War Really Become Impossible?” (1956), in Restoration, 137.

${ }^{144}$ Hans J. Morgenthau, “Atomic Force and Foreign Policy” (1957), in Restoration, 160.
} 
worries that the success of such a war rests on leaders with an almost super-human capacity to determine "just the right atomic dosage" required to avoid defeat without provoking "all-out atomic retaliation." 145 Only by the end of the decade did these doubts develop into a complete and unwavering conception of the novelty of nuclear era. He concludes:

[The] rational relationship between the means of violence and the ends of foreign policy has been destroyed by the availability of nuclear power as a means to achieve those ends. For the possibility of universal destruction obliterates the means-end relationship itself by threatening the nations and their ends with total destruction. No such radical qualitative transformation of the structure of international relations has ever occurred in history. ${ }^{146}$

Nuclear weapons had not only changed the practice of warfare, but had initiated an unprecedented transformation of international politics. ${ }^{147}$

It is hardly surprising that Morgenthau took more than a decade to fully acknowledge the radical novelty of a nuclear era. The tragic worldview that he had advocated in the late 1940s and 1950 s as a polemical weapon against apocalyptic political religions resisted any claims of radical novelty. Against an apocalyptic teleology which expects a ruptural and decisive break with human history, the tragic worldview insists on a cyclical conception of time in which the same conflicts repeat themselves again and again. For Morgenthau, the inescapability of our tragic situation was guaranteed by two static constants of human nature - the lust for power and the will to dominate. ${ }^{148}$ These drives condemn us to a world of unresolvable discord whose patterns are so regular that they can be treated as unchanging laws. ${ }^{149}$ The benefit of a tragic worldview is that we can turn to the past for guidance, as the fundamental conflicts of our age will always have historical analogs. However, the problem with a tragic worldview is not only

\footnotetext{
${ }^{145}$ Morgenthau, “Atomic War,” 140.

${ }^{146}$ Hans J. Morgenthau, "The Intellectual and Moral Dilemmas of Politics" (1960), in The Decline of Democratic Politics (Chicago: University of Chicago Press, 1962), 12.

${ }^{147}$ Scheuerman, Morgenthau, 143.

${ }_{148}$ Morgenthau, Scientific Man, 192.

${ }^{149}$ Morgenthau, Politics Among Nations (1954), 4-13.
} 
that it makes us suspicious of claims to radical novelty, but also leaves us without any intellectual or normative tools to confront that novelty. This is a problem that Morgenthau's University of Chicago colleague Hannah Arendt had already diagnosed with regard to twentiethcentury totalitarianism. We have a tendency, she explains, to equate "totalitarian government with some well-known evil of the past, such as aggression, tyranny, conspiracy." This is understandable. If the evils of the present were also the evils of the past, we can look to the past for political wisdom. The problem is that "the wisdom of the past...dies, so to speak, in our hands as soon as we try to apply it honestly to the central political experiences of our own time. Everything we know of totalitarianism demonstrates a horrible originality which no farfetched historical parallels can alleviate." 150 This is also the dilemma that Morgenthau confronts when his tragic worldview collides with the radical novelty of nuclear weapons. Tragedy had been a valuable antidote for a "civilization that likes to see novelty in history where there is none." However, it was ill-suited for a world which seemed "to perceive but dimly the genuine novelty with which nuclear power confronts it."151

In his remarkable essay, "Death in a Nuclear Age" (1961), Morgenthau adopts a new strategy. Harnessing the darkest fears of annihilation against the radical hope of renewal through nuclear destruction, he calls upon his readers to imagine the apocalypse in order to prevent it. Both the lyrical style of the essay and its existential preoccupations mark a definitive break from his previous writings. ${ }^{152}$ He takes aim at what he sees as a dangerous complacency toward the

\footnotetext{
${ }^{150}$ Hannah Arendt, "Understanding and Politics (The Difficulties of Understanding)" (1954), in Essays in Understanding, 1930-1954, ed. Jerome Kohn (New York: Harcourt Brace, 1994), 309.

${ }^{151}$ Morgenthau, "Intellectual and Moral Dilemma," 12.

${ }^{152}$ Part of the explanation for this shift may lie in the fierce public debates about a nuclear test ban treaty in the early 1960s. However, as William Scheuerman has persuasively argued, "it remains difficult to escape the conclusion that Morgenthau's encounter with Karl Jaspers' influential The Future of Mankind helped to crystallize as well as funnel longstanding anxieties in a constructive theoretical direction." Hannah Arendt had helped to arrange for the translation of Jaspers' book and appears to have asked Morgenthau to review it. The review was published in Saturday Review several months before Morgenthau's essay on nuclear death. Morgenthau praised Jaspers' book as
} 
prospect of a nuclear war. His most obvious target, and one whom he engages directly in other writings of this period, is RAND strategist Herman Kahn. ${ }^{153}$ Throughout the 1950s and 1960s, Kahn argued that a nuclear war would differ only in magnitude, but not in kind, from the wars of the past. The United States could survive a nuclear war and its remaining inhabitants could even resume something like a normal life. ${ }^{154}$ As noted above, on the basis of predictions like these, some went further, seeing nuclear destruction as an opportunity for courage and heroism or, in the words of the 1956 report on "The Human Effects of Nuclear Weapons Development," a chance to "make the very best of the very worst." Popular publications like Time and Life magazines offered hopeful images of families emerging from their fallout shelters ready to create the world anew. For Morgenthau, these are desperate delusions. Implicating both himself and his readers, he warns: "In spite of what some of us know in our reason, we continue to think and act as though the possibility of nuclear death portended only a quantitative extension of the mass destruction of the past and not a qualitative transformation of the meaning of our existence."155

Morgenthau's essay attempts to wrench readers out of this dangerous complacency by offering a bleak account of a nuclear apocalypse without worldly redemption or renewal. The prospect of nuclear annihilation has radically altered man's understanding of himself within time by denying him any hope of immortality. Death, Morgenthau explains, "is the great scandal in the experience of man." It negates everything that "man experiences as specifically human in his existence: the consciousness of himself and of his world, the remembrance of things past and the anticipation of things to come, a creativeness in thought and action which aspires to, and

\footnotetext{
"a work of major importance" and "the only systematic undertaking to integrate the fact of atomic power into a philosophical system." See: Scheuerman, Morgenthau, 146; Hans J. Morgenthau, "An Atomic Philosophy," Saturday Review (February 18, 1961): 18.

${ }^{153}$ See, for example: Hans J. Morgenthau, "The Intellectual and Political Functions of a Theory of International Relations" (1961), in The Decline of Democratic Politics (Chicago: University of Chicago Press, 1962), 70-1.

${ }^{154}$ Kahn makes these arguments in their strongest form in On Thermonuclear War (1960), but softens them somewhat in Thinking About the Unthinkable (1962).

${ }^{155}$ Hans J. Morgenthau, "Death in the Nuclear Age" (1961), in Restoration, 24.
} 
approximates, the eternal." ${ }^{\text {} 156}$ Man preserves his humanity by transcending death. Historically, he has done this in three ways: he has denied the reality of death through a faith in human immortality, he has sought mastery over death through suicide or heroic sacrifice, and he has conquered death by achieving worldly immortality through his deeds and works. The secular modern age has deprived us of the first strategy, while the looming possibility of nuclear death has made the other two absurd.

Many religious believers transcend death through a belief in the immortality of the person. They may assume "that the finiteness of man's biological existence is but apparent and that his body will live on in another world." ${ }^{157}$ Alternatively, they may insist that our specifically human attributes will survive the worldly destruction of our bodies and be preserved in another realm whose shape we can but dimly grasp. Morgenthau argues that religious immortality is no longer available to us in a secular age. And perhaps this is not something that we should lament. If we still had the comfort of religious belief, we could await nuclear death with calm acceptance. Perhaps we could even muster some enthusiasm as we "look forward to the day of the great slaughter as a day on which the preparatory and vain life on this earth would come to an end for most of us and the true, eternal life in another world begin." ${ }^{.158}$ Morgenthau's insistence that this strategy is no longer available to modern man seems to ignore the persistence of religious belief in the secular age. One can only guess at the reasons for his insistence. Perhaps it is a rather blunt rhetorical move aimed at quickly dispensing with the possibility of confronting nuclear death with a sense of hopeful anticipation. Or, maybe Morgenthau is making a more nuanced point about the effects of secularization. Of course, there remain substantial portions of humanity that do have recourse to beliefs about the immortality of the

\footnotetext{
${ }^{156}$ Morgenthau, "Death," 19.

${ }^{157}$ Morgenthau, "Death," 20.

${ }^{158}$ Morgenthau, "Death," 24.
} 
body or soul. They can still look forward to nuclear destruction as the cataclysmic prerequisite for an eternal life in a new world. However, the doubt and skepticism that define the modern age mean that this strategy is, at best, one that can be privately contemplated by the individual believer. It cannot form the basis of a collective and public attempt to grapple with the meaning of death in a nuclear era.

Without a faith in immortality, modern secular man is left with two alternatives, both of which are rendered absurd in the face of nuclear annihilation. First, he can attempt to master death by choosing to end his life through suicide or sacrifice. The latter choice gives him the best chance of being remembered for posterity. The hero who sacrifices himself for a cause gives his death and his life a larger meaning. However, this meaning depends on the existence of a culture or civilization that will live on to interpret and remember this courageous sacrifice. ${ }^{159}$ Drawing on examples from Greek mythology, Morgenthau reasons: "Patroclus dies to be avenged by Achilles. Hector dies to be mourned by Priam. Yet if Patroclus, Hector, and all those who could remember them were killed simultaneously, what would become of the meaning of Patroclus' and Hector's deaths?"160 The mass death that would result from the deployment of a thermonuclear weapon would deprive the individual hero of a surviving culture that could understand and honor his sacrifice. Even if some manage to survive a nuclear war, individual deaths would lose any heroic significance:

There is meaning in Leonidas falling at Thermopylae, in Socrates drinking the cup of hemlock, in Jesus nailed to the cross. There can be no meaning in the slaughter of the innocent, the murder of six million Jews, the prospective nuclear destruction of, say fifty million Americans and an equal number of Russians. There is, then, a radical difference in meaning between a man risking death by an act of will and fifty million people simultaneously reduced—by somebody

\footnotetext{
${ }^{159}$ Hannah Arendt had made a similar point almost a decade earlier: "Man can be courageous only as long as he knows he is survived by those who are like him, that he fulfills a role in something more permanent than himself." See: Hannah Arendt, "Europe and the Atom Bomb" (1954), in Essays in Understanding, 421.

${ }^{160}$ Morgenthau, "Death," 23.
} 
switching a key thousands of miles away - to radioactive ashes, indistinguishable from the ashes of their houses, books, and animals. ${ }^{161}$

Like others writing in the postwar era, Morgenthau finds in the Nazi genocide the closest parallel to the prospect of nuclear annihilation. When death tolls are measured in the millions, lives and deaths have no meaning. The sheer numbers rob the dead of the possibility of worldly immortality through heroic sacrifice. What is remembered, if there is anyone left to remember, is "the quantity of the killed - six million, twenty million, fifty million — not the quality of one man's death as over and against another's." ${ }^{\prime 62}$ Thus, the heroic individual is both physically obliterated by being reduced to radioactive ashes and historically annihilated by being denied the hope of posterity.

The second way in which modern secular man transcends death is by leaving behind the works of his will and his hands as evidence of his existence. He lives on through his children. He creates monuments, leaving behind " an inheritance of visible things not to be consumed but to be preserved as tangible mementos of past generations...'Roma eterna,' 'the Reich of a thousand years' are but the most ambitious attempts to perpetuate man and his deeds. The tree he has planted, the house that he has built, have been given a life likely to last longer than his own."163 Perhaps most importantly, man produces works of the imagination-books, poetry, art-which are lasting testaments to a distinctly human capacity for creativity. When he creates, man participates in "an unbroken chain emerging from the past and reaching into the future, which is made of the same stuff his mind is made of and, hence, is capable of participating in, and perpetuating, his mind's creation."164 Nuclear war would eliminate both the physical products of man's creativity and the culture and civilization that guarantee his worldly

\footnotetext{
${ }^{161}$ Morgenthau, "Death," 23.

162 Morgenthau, "Death," 23.

${ }^{163}$ Morgenthau, "Death," 21.

164 Morgenthau, "Death," 22.
} 
immortality. For as Morgenthau explains elsewhere, even if we were to accept the optimistic assessments that a thermonuclear attack would "only" kill 50 to 100 million Americans, it is foolishly optimistic to believe that civilization could withstand this kind of shock. ${ }^{165}$ Survivors would be reduced to the status of barbarians, deprived of the physical and imaginative artifacts through which the living honor and remember the dead.

Here, Morgenthau's essay takes its most decisive turn, as it rhetorically performs the apocalyptic annihilation whose enormity his contemporaries have systematically failed to grasp:

Nuclear destruction is mass destruction, both of persons and of things. It signifies the simultaneous destruction of tens of millions of people, of whole families, generations, and societies, of all things that they have inherited and created. It signifies total destruction of whole societies by killing their members, destroying their visible achievements, and therefore reducing the survivors to barbarism. Thus nuclear destruction destroys the meaning of death by depriving it of its individuality. It destroys the meaning of immortality by making both society and history impossible. It destroys the meaning of life by throwing life back upon itself. $^{166}$

Like Hobbes in his description of the state of nature, Morgenthau calls forth all the markers of civilization and posterity-families, generations, visible achievements-only to rhetorically annihilate them. In so doing, he offers the reader an apocalypse in which the suffering and death

\footnotetext{
${ }^{165}$ Hans J. Morgenthau (with Sidney Hook, H. Stuart Hughes, and C.P. Snow), "Western Values and Total War," Commentary 32 (October 1961): 281.

${ }^{166}$ Morgenthau, "Death," 22. There are distinct echoes of Arendt's arguments about the nature of worldly immortality: "The task and potential greatness of mortals lie in their ability to produce things—-works and deeds and words - which would deserve to be and, at least to a degree, are at home in everlastingness, so that through them mortals could find their place in a cosmos where everything is immortal except themselves." And later: "Without this transcendence into a potentially earthly immortality, no politics, strictly speaking, no common world and no public realm, is possible. For unlike the common good as Christianity understood it - the salvation of one's soul as a concern common to all - the common world is what we enter when we are born and what we leave behind when we die. It transcends our lifespan into past and future alike; it was there before we came and will outlast our brief sojourn in it. It is what we have in common not only with those who live with us, but also with those who were here before and with those who will come after us." See: Hannah Arendt, The Human Condition (Chicago: University of Chicago Press, 1998 [1958]), 19, 55. This is precisely the kind of worldly immortality that nuclear destruction makes impossible, according to Morgenthau. While he does not cite Arendt in this passage, we know that Morgenthau held her work, and The Human Condition in particular, in high esteem. When asked to name the ten books that had had the greatest intellectual influence on him, Morgenthau included The Human Condition, alongside works by Plato, Aristotle, Publius, and Nietzsche. See: Frei, Hans J. Morgenthau, 113.
} 
of millions are deprived of meaning. Those who survive are not an elect, but a shattered remnant reduced to barbarism. Against the looming prospect of a nuclear apocalypse, Morgenthau stages a rhetorical apocalypse to shake his readers from their "thoughtless optimism."167 In short, he fights apocalypse with apocalypse, calling upon his readers to imagine nuclear annihilation in order to prevent it.

Such prevention could be achieved in the long term only with an appropriate institutional solution. Since the late 1940 's, Morgenthau had recognized that the only reliable safeguard against total annihilation was a world state with a monopoly on nuclear violence: "It is only when nations have surrendered the means of destruction which modern technology has put in their hands to a higher authority — when they have given up their sovereignty—-that international peace can be made as secure as domestic peace."168 Yet such a state was not possible in the absence of a world society. The unity of mankind would have to precede the creation of a world state. In a world marked by crusading political religions and the absence of any supranational moral consensus, this kind of unity seemed like a dim and futile hope. By the 1960s, however, Morgenthau had begun to recognize in the prospect of nuclear annihilation not just a novel threat, but also a novel possibility. It presents us with nothing less than an opportunity to effect a fundamental transformation of humanity. An inchoate "awareness of the unity of mankind," long submerged by the political religions of crusading nationalisms, has been sharpened by the common fear of nuclear death. ${ }^{169}$ Our longing to give some political and institutional form to this unity has been greatly strengthened in the nuclear age "by the desire, innate in all men, for self-preservation." This desire could now be harnessed, in a way that had previously been impossible, to abolish "international relations itself through the merger of all national

\footnotetext{
${ }^{167}$ Morgenthau, "Death," 24-5.

${ }^{168}$ Morgenthau, Politics Among Nations (1948), 445.

${ }^{169}$ Hans J. Morgenthau, "International Relations (1961)," in Restoration, 174-5.
} 
sovereignties into one world state which would have a monopoly of the most destructive instruments of violence." 170

However, Morgenthau's essay on nuclear death betrays some doubt about whether we can rely on this innate desire to emerge on its own as a political force. Clinging to the hope of secular immortality, we fail to grasp the enormity of the nuclear threat. Hobbes had faced a similar dilemma. While he suggested that the fear of earthly death is our most basic and reliable fear, he worried that it may ultimately be overpowered by the terror of eternal damnation. Our fear of death cannot be relied upon as a natural force. It must be actively cultivated. Hobbes did this, at least in part, by neutralizing the threat of eternal torment and by offering an apocalyptic account of the breakdown of political order. Morgenthau, I suggest, might be attempting a similar rhetorical endeavor as he strips his readers of the comforts of secular immortality and leaves them with a terrifying account of nuclear annihilation that facilitates the cultivation of a salutary fear. He envisions a radical transformation of human nature. ${ }^{171}$ No longer would humans be driven by our pursuit of power or our will to dominate. In the shadow of nuclear apocalypse, self-preservation would become our guiding motivation and the basis for a project of permanent peace. Thus prepared, perhaps his audience will be more willing to accept our common humanity and to contemplate the possibility of a world state.

This is where the irony of Morgenthau's position becomes clear. In attempting to combat dangerously hopeful scenarios of nuclear apocalypse, he succumbs to the millennial fantasy of a

\footnotetext{
${ }^{170}$ Morgenthau, "International Relations," 175.

${ }^{171}$ This is a point on which Morgenthau's observations seem to align with those of Jaspers. The latter had argued that the solution to the existential threat of nuclear annihilation would require "the forces in man to well up from such depths as to transform him in his moral, rational, political aspects - a transformation so extensive that it would become the turning point of history." See: Karl Jaspers, The Future of Mankind, trans. E.B. Ashton (Chicago: University of Chicago Press, 1958), 4. Hannah Arendt had made a somewhat similar point in 1954: "By putting in jeopardy the survival of mankind and not only individual life or at the most the life of a whole people, modern warfare is about to transform the individual mortal man into a conscious member of the human race, of whose immortality he needs to be sure... and for whose survival he must care more than for anything else." See: Arendt, "Europe and the Atom Bomb," 422.
} 
world state able to guarantee permanent peace. Yet Morgenthau could never clearly specify what such a world state would look like. Its contours remain fundamentally unimaginable. He is willing to accept, with Hobbes, that "society has no substitute for the power of the Leviathan whose very presence, towering above contending groups, keeps their conflicts within peaceful bounds." ${ }^{172}$ However, he cannot bring himself to accept the possibility of a global equivalent to the Hobbesian sovereign, a universal tyranny capable of terrorizing an "unwilling humanity" into perpetual peace. He declares that "such a world state would be a totalitarian monster resting on feet of clay, the very thought of which startles the imagination." ${ }^{, 173}$

Throughout the 1960s, he toys with various alternatives that all fall short of a world state with a monopoly on violence. He considers the possibility of an American-led "free association" of liberal democratic states that would exercise supranational control over nuclear weapons, a concerted effort by the United Nations "to point the world in the direction of replacing national sovereignty with supranational decisions and institutions," and a system of joint Soviet and American sovereignty over the world. ${ }^{174}$ All of these solutions fall short of the "New Leviathan" that would be required to guarantee permanent peace and human survival in a nuclear world. ${ }^{175}$ Morgenthau's inability to imagine the contours of the world state strikes some of his critics an intellectual failing - a fundamental theoretical incoherence or an unwillingness to fully abandon a narrow realism that was dangerously unsuited to a nuclear world. ${ }^{176}$ I might suggest instead that it is the vestiges of a tragic realism, with its insistence that projects of permanent peace are

\footnotetext{
${ }^{172}$ Morgenthau, Politics Among Nations (1948), 397.

${ }^{173}$ Morgenthau, Politics Among Nations (1948), 404.

${ }^{174}$ Hans J. Morgenthau, The Purpose of American Politics (New York: Alfred Knopf, 1960), 309; Hans J. Morgenthau, "Threat to-and Hope for-the United Nations," in Restoration, 284; Hans J. Morgenthau (with Reinhold Niebuhr), "The Ethics of War and Peace in the Nuclear Age," War/Peace Report (February 1967$), 7$.

${ }^{175}$ I am borrowing the term "New Leviathan" from Campbell Craig's Glimmer of a New Leviathan.

${ }^{176}$ Speer, "Hans Morgenthau and the World State," 207-227; Scheuerman, Morgenthau, 157-8.
} 
the most dangerous forms of political escapism, that prevents him from surrendering completely to the millennial fantasy of a world without conflict.

\section{Conclusion}

In this chapter, I have argued that Morgenthau's political realism was shaped by the postwar apocalyptic imaginary. In his writings from the late 1940s and 1950s, he was centrally preoccupied with the violent potential of a world divided by crusading political religions who had found in nuclear weapons the means to match their totalizing ends. The bulk of his critical attention is directed at liberal internationalism, at the roots of which he sees an apocalyptic hope for a final and decisive war that will usher in an age of permanent peace. Like Machiavelli, Morgenthau turns to a tragic worldview that insists on the inescapability of conflict and the limits to transformative political action. However, this tragic turn left Morgenthau ill-equipped to confront the radical novelty of nuclear weapons. By the early 1960 s, he had taken a dramatic turn away from a tragic worldview and toward a Hobbesian strategy of fighting apocalypse with apocalypse. Depriving us of any hope for secular redemption in the wake of nuclear annihilation, he asks us to imagine the apocalypse in order to prevent it. In so doing, Morgenthau hopes that we may be able to effect the kind of profound human transformation required to accept a world state.

This argument has several implications for Morgenthau's identification as a political realist. First, as was the case with Machiavelli and Hobbes, this reading suggests that Morgenthau's thought was deeply contextual. Yet his realism does not develop simply from a clear-eyed analysis of material facts on the ground but also from a struggle about how to imagine and interpret the significance of those events. Features of the postwar apocalyptic imaginary 
seem to haunt his work. The eschatological underpinnings of Nazism loom in the background of his worries about the apocalyptic basis of liberal internationalism, while the mass exterminations of the Holocaust provide the only possible analog for the unimaginable prospect of nuclear annihilation. Second, the interpretation I have offered here points to the deeply normative core of Morgenthau's realism. In his tragic phase, he rejects liberal schemes for permanent peace not primarily on the basis of an assessment of their empirical possibility, but of a profoundly normative evaluation of their inevitable dangers. In his apocalyptic phase, he calls for nothing short of a fundamental transformation of human nature. Instead of accepting men as they are, he offers a terrifying vision aimed at transforming them into what they should be. Finally, this reading questions whether the tragic realism that had defined Morgenthau's early writings may be ill-equipped to confront radically novel threats to human survival. Captivated by the prospect of nuclear annihilation, Morgenthau abandoned a tragic worldview and embraced the rhetorical potential of the apocalyptic imaginary. In so doing, he flirted with the very kind of utopian project he had once condemned as a "repudiation of politics." The concluding chapter of the dissertation will suggest that Morgenthau's abandonment of tragedy was perhaps too hasty and that there are valuable normative resources within the tradition of tragic realism for responding to contemporary hopes and fears about the end of the world. 


\section{CHAPTER SIX}

\section{CONCLUSION: ON THE ART OF LIVING THROUGH CATASTROPHE}

In the foregoing chapters, I have attempted to demonstrate that Machiavelli, Hobbes, and Morgenthau's engagements with apocalyptic fears and hopes shaped the works of these canonical political realists. In making this claim, however, I am not endorsing the conventional argument that political realism always emerges as a reaction to or critique of some kind of utopianism. Instead, I have argued that the ways in which these thinkers respond to apocalypticism go far beyond mere reaction or criticism. Machiavelli, Hobbes, and Morgenthau all acknowledge the appeal of the apocalyptic imaginary whilst also struggling to negotiate its dangers. Despite their firm realist opposition to perfectionist political projects, all three thinkers at some point succumb to the apocalyptic imaginary's radical utopianism. However, I do not think that this finding should lead us to question the identification of these thinkers as realists so much as it should force us to acknowledge the difficulty of maintaining a thorough-going realism. All of these thinkers wrestle with the challenge of political realism in apocalyptic times - that is, how to instruct their audiences "in the art of living through an age of catastrophe" without apocalyptically surrendering to it. ${ }^{1}$

\section{The Apocalyptic Imaginary Revisited}

Part of the challenge of the apocalyptic imaginary resides in the fact that the very features that make it politically seductive are also those that render it radically unstable. First, the apocalyptic imaginary is hostile to established forms of power. In Chapter 2, I considered the

\footnotetext{
${ }^{1}$ When Henri Marrou characterizes the value of St. Augustine's teaching for modern readers, he writes that the medieval theologian "instructs us by his example in the art of living through an age of catastrophe." See: Henri Marrou, St. Augustine and his Influence Through the Ages, trans. Patrick Hepburne-Scott (New York: Harper Torchbooks, 1957). I think that this is also a good characterization of the normative project of political realism, particularly in the cases of the three thinkers covered in this dissertation.
} 
way in which this hostility manifests itself in the books of Daniel and Revelation, the textual loci of the apocalyptic imaginary. Drawing on the symbolic resources of Near Eastern mythology, both books cast sovereign power as a sea beast, a chaos monster that God must slay in order to make his sovereignty once again manifest on earth. The appeal of such a message in the face of real or perceived persecution is understandable. It confirms a suspicion that the political world is radically out of joint. For those who remain complacent and complicit with sovereign power, the message defamiliarizes this power by casting it in a new and terrifying light. As I explored in Chapter 4, this radical critique of sovereign power was deployed to tremendous effect during the English Civil War. Puritan populist and Parliamentarian forces identified the Laudian Church and Charles I with Antichrist and the Beast of Revelation, casting established ecclesiastical and royal power as deeply alien and antithetical to God's sovereignty. The danger of this way of imagining one's enemy is, of course, that it obliterates moral limits on the use of force. As Stephen Marshall advised in a speech before Parliament in 1642: "If this work be to avenge God's church against Babylon, he is a blessed man that takes and dashes the little ones against the stones." ${ }^{2}$ Anyone seen as an ally of the monstrous forces of chaos becomes a target for divinely sanctioned annihilation.

Second, the apocalyptic imaginary brings narrative coherence to events that seem radically contingent. The books of Daniel and Revelation made the experiences of persecution and trauma under Hellenic and Roman rule meaningful. The suffering of believers was transformed from an experience of inexplicable evil to the necessary birth pangs of a new world. As I discussed in Chapter 3, the Florentine apocalyptic imaginary, especially in its Savonarolan form, also imposed a divine order on history. In a matter of days during November 1494,

\footnotetext{
${ }^{2}$ As quoted in: Paul Christianson, Reformers and Babylon: Apocalyptic Visions from the Reformation to the Eve of the Civil War (Toronto: University of Toronto Press, 1978), 185.
} 
Florence witnessed the crumbling of the Medici regime and the invasion of Charles VIII's forces. These were terrifying events whose outcomes seemed radically uncertain. In channeling the apocalyptic imaginary, Savonarola promised to give these events both a meaning and an end. He imagined Charles as a divine agent who would purge Florence of its sins and mark the beginning of the apocalypse described in Revelation. Savonarola's genius lay in his ability to adapt this narrative to suit changing circumstances. When Charles and his forces left Florence largely undamaged, the friar interpreted this as a sign of the city's elect status as a New Jerusalem. As appealing as this narrative was during a particularly unstable and unpredictable period in Florence's history, its promise of a spontaneous and peaceful transformation masked both the difficult work that would be involved in creating a spiritual republic and the deep political tensions that these labors would unleash. Within four years of Charles' invasion, Savonarola had been executed as a heretic and Florence was once again at the mercy of factional conflict. Far from bringing a meaning and an end to the city's political difficulties, the Savonarolan moment likely exacerbated them.

Third, the apocalyptic imaginary holds out the seductive promise that conflict and difference can be eliminated. Daniel envisions a new order in which God gathers his people together to be ruled as one. All differences of race, nationality, and language melt away. Similarly, John of Patmos promises that Jesus' faithful followers will receive new clothes and new names. Markers of individuality will be eliminated as the elect surrender to Jesus' transformative omnipotence. With difference and individuality abolished, "death will be no more; mourning and crying and pain will be no more, for the first things have passed away."3 Insofar as the political condition is one marked by inescapable conflict and enduring differences, the apocalyptic imaginary does not just promise an end to persecution but also an end to politics.

\footnotetext{
${ }^{3} \operatorname{Rev}$ 21:4.
} 
As I argued in Chapter 5, Hans Morgenthau diagnoses a secular variant of this hope in American liberal internationalism, which he argues sees a final war for humanity as the prerequisite for a millennial democratic future. Underlying this seemingly laudable end, writes Morgenthau, is the fantasy of an escape from the ineliminable conflict of the political condition. He suggests that this apocalyptic vision is at its most dangerous when the expected end fails to materialize and the final war becomes the forerunner "of wars more destructive and extensive than any liberal epoch had witnessed." Whether or not Morgenthau's worries were vastly overstated or disturbingly prescient will largely depend on one's own assessment of the wars that the United States has waged in the name of liberty and democracy over the past sixty years.

\section{Political Realist Responses to the Apocalyptic Imaginary}

As I attempted to demonstrate in the preceding chapters, Machiavelli, Hobbes, and Morgenthau respond to the appeal and dangers of the apocalyptic imaginary in two ways. Machiavelli and the early Morgenthau reject the apocalyptic imaginary and turn to a tragic worldview that, while insistent on the limits to effective political action and resistant to perfectionist projects, does not endorse a withdrawal from worldly pursuits. I argue that Machiavelli only comes to this tragic position after having flirted with the apocalyptic imaginary in The Prince. His most famous work culminates in an apocalyptic exhortation because he fails to fulfill the opening promise of the book - to make the variability of politics intelligible and subject to human control. I find a more developed and tragic realism in The Discourses, where Machiavelli subjects the apocalyptic hope of worldly transformation to serious normative scrutiny. This extended engagement with the apocalyptic imaginary coincides with a maturation of his political realism from a misconceived project of intelligibility and control in The Prince to

\footnotetext{
${ }^{4}$ Hans Morgenthau, Scientific Man vs. Power Politics (Chicago: University of Chicago Press, 1948), 67.
} 
the more modest but difficult attempt to cultivate a tragic wisdom in The Discourses. The early Morgenthau responds to the secularized apocalyptic elements of liberal internationalism with a tragic stance that similarly insists on the inescapability of conflict and the limits to transformative political projects. For Morgenthau, however, this tragic stance ultimately seems unable to confront the radical novelty of nuclear weapons and the threat they pose to the future of the world.

In the work of Hobbes and the late Morgenthau, I find a different response to the apocalyptic imaginary. Rather than turning away from it and toward a tragic sensibility, Hobbes and the late Morgenthau fight apocalypse with apocalypse. That is, they redeploy elements of the apocalyptic imaginary and call on their audiences to imagine the end of the world in order to prevent it. Hobbes does this in two ways. In his theological argument, he offers a de-radicalized Christian eschatology that affirms important parts of the narratives of Daniel and Revelation whilst making the apocalyptic imaginary safe for sovereign power. In his political argument, Hobbes offers an apocalyptic account of the state of nature in order to legitimize the rule of an absolute sovereign. His use of terrifying apocalyptic imagery and rhetoric here suggests that while he might prefer to persuade by appealing to reason and prudence, he is willing to do so by burrowing into the darker corners of the imagination.

Morgenthau adopts a similar strategy in response to the novel threat of nuclear weapons. He offers a terrifying account of an apocalypse without redemption in the hope that such a vision may be able to effect the human transformation necessary for the creation of a world state. In the case of both Hobbes and Morgenthau, this turn to the apocalyptic imaginary legitimizes potentially dangerous utopian projects. For Hobbes this project is the submersion of individual wills into the single will of the sovereign, while for Morgenthau it is the submersion of diverse 
states into a powerful world state. For both thinkers, these endeavors are premised on the perfectionist hope for a fundamental transformation of humanity. In short, for both Hobbes and Morgenthau, the redeployment of the apocalyptic imaginary coincides with the abandonment of key tenets of these thinkers' political realism.

\section{The Promise and Limits of a Tragic Vision}

It has likely become plain by now that I am inclined to think that the tragic worldview is not only more consistent with constitutive features of the political realist position, but also that it assumes a more defensible normative stance than the apocalyptic imaginary. This is indeed the case. I certainly do not deny that the apocalyptic imaginary, particularly as it is articulated in the Judeo-Christian tradition, contains positive normative resources. At its best, it demonstrates a concern for the persecuted and oppressed, offering them not only hope and consolation but also a radical vision of a world in which established hierarchies have been abolished. It privileges a concern with power and justice and provides rhetorical and imaginative resources for challenging enduring forms of inequality. ${ }^{5}$ At its worst, however, the apocalyptic imaginary cultivates a profoundly dangerous certainty — certainty about the course and goals of history, certainty about who and what is evil, and certainty about "our" goodness and righteousness. In so doing, the apocalyptic imaginary takes aim at the features of the contemporary world that are at once most valued and most feared—its indeterminacy, ambiguity, and pluralism. ${ }^{6}$

\footnotetext{
${ }^{5}$ For readings of Revelation that emphasize these dimensions, see: Néstor Míguez, "Apocalyptic and the Economy: A Reading of Revelation 18 From the Experience of Economic Exclusion," in Reading from This Place, vol. 2: Social Location and Biblical Interpretation in Global Perspective, eds. Francis F. Segovia and Mary Ann Tolbert (Minneapolis: Fortress Press, 1995): 250-62; Elisabeth Schüssler Fiorenza, The Book of Revelation: Justice and Judgment (Philadelphia: Fortress Press, 1985), esp. 181-203.

${ }^{6}$ Catherine Keller, God and Power: Counter-apocalyptic Journeys (Minneapolis: Fortress Press, 2005$), 12$.
} 
It was both the certainty of this imaginary and its choice of targets that many of the critics of the Bush Administration found so disturbing about the President's post-9/11 apocalyptic rhetoric. Bush seemed certain about the direction of history when he proclaimed: "the untamed fire of freedom will reach the darkest corners of our world."7 He allowed for no moral ambiguity when he declared: "Either you are with us, or you are with the terrorists." ${ }^{\prime 8}$ And he evinced a profound faith in America's righteousness when he described the country's mission as the defense of "freedom...civilization... and universal values." Yet Bush and his supporters were not the only ones captured by the apocalyptic imaginary. Those most critical of the President's rhetoric and the policies it was meant to defend also gravitated to the rhetorical and visual resources of apocalypse. Feminist theologian Catherine Keller offers a personal account of this apocalyptic reply:

Even the progressive U.S. response gets caught in the apocalyptic mirror-game. Chickens come home to roost: the real cause is our policy in the Middle East, especially Israel, or the real cause is the global economy. While I heard myself in the initial shock laying these propositions on my students, and heard them echoing through my theological community, their indignant certainties rang hollow at ground zero. I needed something more difficult and honest than the monocausal explanations, the warmed-over and misfitting Vietnam-era slogans, the I-told-you-so's that did not...Indeed the very model of a monocausal explanation, with its linear predictability and its indignant certainty, echoes with the hoofbeats of secular apocalypse. ${ }^{10}$

The "apocalyptic mirror-game" that Keller describes is a process whereby those who most want to resist apocalypticism are nonetheless drawn back to it by its promise of certainty and intelligibility. In this diagnosis, Keller has identified what is most powerful and troubling about

\footnotetext{
${ }^{7}$ George W. Bush, Second Inaugural Address (January 20, 2005), accessed August 15, 2011, http://www.presidency.ucsb.edu/ws/index.php?pid=58745\#axzz1W1KOUh9B

${ }^{8}$ George W. Bush, Address Before a Joint Session of Congress (September 20, 2001), accessed August 15, 2011, http://www.presidency.ucsb.edu/ws/index.php?pid=64731\&st=\&st1=\#axzz1 W1KOUh9B

${ }^{9}$ George W. Bush, Remarks on Arrival in Daytona Beach (January 30, 2002), accessed August 15, 2011, http:/www.presidency.ucsb.edu/ws/index.php?pid=73243\&st=\&st1=\#axzz1 W1KOUh9B

${ }^{10}$ Keller, God and Power, 12-13.
} 
the apocalyptic imaginary - the profound hold it can have even over those who are trying to resist it.

Keller attempts to disrupt this mirror-game by adopting what she calls a "counterapocalyptic" position. This stance resists the linear temporality, righteous certainty, and totalizing violence of the apocalypse while attempting to preserve the radical political traditions of apocalypticism that value "disclosure, rather than final closure." 11 I think that the tragic sensibility that I find in the work of Machiavelli and the early Morgenthau encourages an intellect capable of "counter-apocalypse." William Connolly summarizes this tragic vision in a way that highlights its counter-apocalyptic features. A tragic vision, he explains, requires that one "doubt the providential image of time, reject the compensatory idea that humans can master all the forces that impinge upon life, strive to cultivate wisdom about a world that is neither designed for our benefit nor plastic enough to be putty in our hands, and cultivate temporal sensitivity to how this or that concatenation of events could issue in the worst." ${ }^{\prime 2}$ Machiavelli and the early Morgenthau further demand that we do not turn away from this world that is not wholly our own, but rather shore up the courage required for political action when success is neither guaranteed nor free from the possibility of moral corruption. ${ }^{13}$

\footnotetext{
${ }^{11}$ Keller, God and Power, 88.

${ }^{12}$ William E. Connolly, Capitalism and Christianity, American Style (Durham: Duke University Press, 2008), 121.

${ }^{13}$ When I invoke the possibility of moral corruption here, I am not primarily thinking of "moral deterioration or decay" or the abuse of a position of trust and authority for personal ends. See: Oxford English Dictionary [online edition], 2011. Rather, I am thinking of the more subtle tendency toward a kind of rationalization that chips away at the strength and validity of moral claims "to make them better suited to our wishes and inclinations." See: Immanuel Kant, Groundwork on the Metaphysics of morals, in Practical Philosophy, trans. and ed. Mary J. Gregor (Cambridge: Cambridge University Press, 1996), 4:405, 60. In Kant's account, moral corruption is more subtle than the dictionary definition cited above suggests. It is often indirect, and sometimes systemic. As Stephen Gardiner explains, "under such circumstances, it can, from the external perspective, be difficult to find anyone to blame in the usual way. After all, those who offer bad arguments or mistaken values may act in good faith, as might many of those who accept their positions." See: Stephen M. Gardiner, The Perfect Moral Storm: The Ethical Tragedy of Climate Change (New York: Oxford University Press, 2011), [Kindle Edition], ch. 9, part I, sec. 2. I think that a tragic realism, at I have outlined the position in this dissertation, is particularly attuned to the subtle dangers of moral corruption. However, I also suspect that political realism in general is especially vulnerable to the
} 
However, while tragic realism may be the more responsible normative stance to hold in a complex and contingent political world, it seems ill equipped to confront apocalypticism on the battleground of the imagination. In Chapter 2, I argued that one of the reasons that the apocalyptic imaginary continues to captivate even in contexts far different from those of the original audiences of Daniel and John of Patmos is that it draws upon a dense and almost infinitely flexible network of symbols. Both the rhetoric and imagery of these texts open up "the vertiginous possibilities of referential aberration." ${ }^{\text {14 }}$ The books of Daniel and Revelation at once invite endless and often contradictory interpretations whilst confounding the possibility of a single definitive reading. This gives the apocalyptic imaginary an almost unparalleled capacity to travel through time to radically different historical contexts. This capacity is further guaranteed by the fact that Revelation remains the most illustrated book of the bible, which may help to explain how images like the four horsemen of the apocalypse, the Whore of Babylon, and the Beast resonate even for audiences completely unfamiliar with the narrative details of the Judeo-Christian apocalypse.

Even more importantly, however, the apocalyptic imaginary captivates. In offering a terrifying vision of a cataclysmic world transformation, it represents the unrepresentable. ${ }^{15}$ These sublime visions elicit a combination of awe and terror. With sufficient distance - as when they appear in an affecting sermon, or in an ambitious painting, or on the television screen, these scenes are even capable of eliciting that unique kind of pleasure that accompanies the sublime. Edmund Burke evokes this kind of pleasurable captivation when he argues: "there is no spectacle we so eagerly pursue, as that of some uncommon and grievous calamity...The delight we have in

\footnotetext{
kinds of rationalizations — often in the name of prudence, necessity, or expediency — that lead to this kind of moral corruption.

${ }^{14}$ Paul De Man, “Semiology and Rhetoric,” Diacritics 3, no. 3 (1973): 30.

${ }^{15}$ Jonathan Alexander, "The Last Things: Representing the Unrepresentable," in The Apocalypse and the Shape of Things to Come, ed. Frances Carey (Toronto: University of Toronto Press, 1999), 43-63.
} 
such things, hinders us from shunning scenes of misery...and all this antecedent to any reasoning, by an instinct that works us to its own purposes without our concurrence."16 This is the kind of apocalyptic captivation that held audiences spellbound as they listened to Savonarola's fiery sermons or watched as the Trinity test bomb exploded in the New Mexico sky.

For all its normative resources, the tragic worldview cannot match this imaginative power. Throughout this dissertation I have consciously referred to an apocalyptic imaginary and a tragic worldview, vision, or sensibility. This is because I harbor serious doubts about the capacity of the tragic vision of Machiavelli and the early Morgenthau to engage the imagination, particularly in a way that is "antecedent to any reasoning." In fact, tragic realism emerges explicitly in response to what it takes to be a dangerous imaginative captivation. To be sure, the best classical examples of tragic theatre would no doubt have engaged both the imagination and the reason. Peter Euben provides one of the more robust accounts of the extraordinary ambitions of classical tragedy:

[It] evoked and provoked its audience into participating in the task of deconstructing and reconstructing a world that was both familiar and other. It awakened and enlivened the mind and heart, arousing emotions and reason... Showing people learning to change, tragedy helped its audience see the need to do the same: seeing the connection between belief and action on stage, the audience could recognize how its own ideas shape its beliefs and actions. The characters we see on stage, searching for the right thing to say and do in difficult circumstances, help us interpret our own difficulties... Tragedy does not so much provide us with a solution as insist on the depth of the problems and the dangers of a 'problem-solving' mentality. ${ }^{17}$

\footnotetext{
${ }^{16}$ Edmund Burke, "A Philosophical Inquiry into the Origin of Our Ideas of the Sublime and Beautiful with Several Other Additions," in On Taste, On the Sublime and Beautiful, Reflections on the French Revolution, Letter to a Noble Lord (New York: P.F. Collier and Son, 1909), 42.

${ }^{17}$ J. Peter Euben, The Tragedy of Political Theory: The Road Not Taken (Princeton: Princeton University Press, 1990), 58.
} 
Tragedy seems to lose some of its extraordinary imaginative and formative power in its translation from a dramatic form to a worldview or sensibility. The mature Machiavelli and the early Morgenthau find in tragedy the normative resources for cultivating a counter-apocalyptic disposition to the world. But for both thinkers, the achievement of this disposition is both hardfought and precarious. Morgenthau abandons his tragic realism when he finds it unable to cope with the radical novelty of nuclear weapons. When faced with the prospect of human annihilation, he seems to conclude, tragedy is not enough. While Machiavelli's rejection of the apocalyptic imaginary is more enduring, his tragic realism is haunted by the millennial hope of a perpetual republic free from the conflict and contingency of politics. To the extent that one may characterize the normative work of political realism as cultivating the art of living through catastrophe, the experiences of the thinkers in this dissertation suggest that this is a practice to which one must repeatedly recommit without any reasonable hope of success. 


\section{BIBLIOGRAPHY}

Alexander, Jonathan. "The Last Things: Representing the Unrepresentable." In The Apocalypse and the Shape of Things to Come, edited by Frances Carey, 43-63. Toronto: University of Toronto Press, 1999.

Alvarez, A. “The Concentration Camps.” The Atlantic Monthly (December 1962): 69-72.

Arendt, Hannah. Eichmann in Jerusalem: A Report on the Banality of Evil. New York: Penguin, 1977.

Arendt, Hannah. Essays in Understanding, 1930-1954, edited by Jerome Kohn. New York: Harcourt Brace, 1994.

Arendt, Hannah. The Human Condition. Chicago: University of Chicago Press, 1998.

Ascoli, Albert Russell. "Machiavelli's Gift of Counsel." In Machiavelli and the Discourse of Literature, edited by Albert Russell Ascoli and Victoria Kahn, 219-57. Ithaca: Cornell University Press, 1993.

Augustine. Concerning The City of God Against the Pagans, translated by Henry Bettenson. Harmondsworth: Penguin, 1972.

Augustine. The Works of Saint Augustine, volume 2, no. 3, translated by Roland Teske. Charlottesville: InteLex, 2001. Electronic edition.

Bacon, Francis. Bacon's Essays, edited by F.G. Selby. London: MacMillan and Co., 1889.

Bárberi-Squarotti, Giorgio. La forma tragica del 'Principe' e altri saggi sul Machiavelli. Florence: Olschki, 1966.

Barkun, Michael. Disaster and the Millennium. New Haven: Yale University Press, 1974.

Berger, James. After the End: Representations of Post-Apocalypse. Minneapolis: University of Minnesota Press, 1999. 
Bernstein, Michael André. Forgone Conclusions: Against Apocalyptic History. Berkeley: University of California Press, 1994.

Betteridge, Maurice S. "The Bitter Notes: The Geneva Bible and Its Annotations." The Sixteenth Century Journal 14, no.1 (1983): 41-62.

Bisaha, Nancy. Creating East and West: Renaissance Humanists and the Ottoman Turks. Philadelphia: University of Pennsylvania Press, 2006.

Bottici, Chiara. "Imaginary, The." In Encyclopedia of Political Theory, volume 1, edited by Mark Bevir, 685-7. Thousand Oaks: 2010.

Boucher, David. Political Theories of International Relations: From Thucydides to the Present. Oxford: Oxford University Press, 1998.

Bousquet, Antoine. "Time Zero: Hiroshima, September 11 and Apocalyptic Revelations in Historical Consciousness." Millennium: Journal of International Studies 34, no. 3 (2006): 739-64.

Boyer, Paul. When Time Shall Be No More: Prophecy Belief in Modern American Culture. Cambridge: Harvard University Press, 1992.

Boyer, Paul. Fallout: A Historian Reflects on America's Half-Century Encounter with Nuclear Weapons. Columbus: Ohio State University Press, 1998.

Bredekamp, Hors. "Thomas Hobbes's Visual Strategies." In The Cambridge Companion to Hobbes's Leviathan, edited by Patricia Springborg, 29-60. Cambridge: Cambridge University Press, 2007.

Brown, Alison. "Introduction." In Selected Writings of Girolamo Savonarola: Religion and Politics, 1490-1498, edited and translated by Anne Borelli and Maria Pastore Passaro, xv-xxxv. New Haven: Yale University Press, 2006.

Brown, Chris. "'The Twilight of International Morality'? Hans J. Morgenthau and Carl Schmitt on the end of the Jus Publicum Europaeum." In Realism Reconsidered: The Legacy of 
Hans Morgenthau in International Relations, edited by Michael C. Williams, 42-61. Oxford: Oxford University Press, 2007.

Brown, Keith. "The artist of the Leviathan title-page." British Library Journal 4, no. 1 (1978): 24-36.

Brown, Keith. "Thomas Hobbes and the Title-page of Leviathan." Philosophy 55, no. 213 (1980): 410-11.

Buck-Morss, Susan. Dreamworld and Catastrophe: The Passing of Mass Utopia in East and West. Cambridge: MIT Press, 2000.

Bundy, Harvey H. "Remembered Words.” The Atlantic (March 1957): 56-7.

Burke, Edmund. "A Philosophical Inquiry into the Origin of Our Ideas of the Sublime and Beautiful with Several Other Additions." In On Taste, On the Sublime and Beautiful, Reflections on the French Revolution, Letter to a Noble Lord. New York: P.F. Collier and Son, 1909.

Bush, George W. Address Before a Joint Session of Congress. September 20, 2001. Accessed August 15, 2011.

http://www.presidency.ucsb.edu/ws/index.php?pid=64731\&st=\&st1=\#axzz1 W1KOUh9B

Bush, George W. Address to the Nation Announcing Strikes Against Al Qaida Training Camps and Taliban Military Installations in Afghanistan. October 7, 2001. Accessed July 20, 2011. http://www.presidency.ucsb.edu/mediaplay.php?id=65088\&admin=43.

Bush, George W. Remarks on Arrival in Daytona Beach. January 30, 2002. Accessed August $15,2011$.

http://www.presidency.ucsb.edu/ws/index.php?pid=73243\&st=\&st1=\#axzz1W1KOUh9B

Bush, George W. State of the Union Address. January 28, 2003. Accessed: July 20, 2011. http://www.presidency.ucsb.edu/ws/index.php?pid=29645\#axzz1UZTKZP00.

Bush, George W. Second Inaugural Address. January 20, 2005. Accessed August 15, 2011. http://www.presidency.ucsb.edu/ws/index.php?pid=58745\#axzz1W1KOUh9B. 
Cannon, Lou. President Reagan: The Role of a Lifetime. New York: PublicAffairs, 2000.

Capp, Bernard. "The Political Dimension of Apocalyptic Thought." In The Apocalypse in English Renaissance Thought and Literature: Patterns, Antecedents and Repercussions, edited by C.A. Patrides and Joseph Wittreich, 93-124. Ithaca: Cornell University Press, 1984.

Carey, Frances, ed. The Apocalypse and the Shape of Things to Come. Toronto: University of Toronto Press, 1999.

Carruthers, Mary. The Craft of Thought: Meditation, Rhetoric, and the Making of Images, 4001200. Cambridge: Cambridge University Press, 1998.

Christianson, Paul. Reformers and Babylon: English Apocalyptic Visions From the Reformation to the Eve of the Civil War. Toronto: University of Toronto Press, 1978.

Clifford, Richard J. "The Roots of Apocalypticism in Near Eastern Myth." In The Continuum History of Apocalypticism, edited by Bernard J. McGinn, John J. Collins, and Stephen J. Stein, 3-29. New York: Continuum, 2003.

Cohen, Leonard. "The Future.” The Future. Columbia, 1992.

Cohn, Norman. The Pursuit of the Millennium: Revolutionary Messianism in Medieval and Reformation Europe and its Bearing on Modern Totalitarian Movements. London: Secker and Warburg, 1957.

Cohn, Norman. The Pursuit of the Millennium: Revolutionary Messianism in Medieval and Reformation Europe and Its Bearing on Modern Totalitarian Movements, second edition. New York: Harper Torchbooks, 1961.

Colish, Marcia L. "Republicanism, Religion, and Machiavelli's Savonarolan Moment." Journal of the History of Ideas 60, no. 4 (1999): 597-616.

Collingwood, R.G. An Autobiography. Oxford: Oxford University Press, 1978. 
Collins, John J. “Apocalypse: Towards the Morphology of a Genre.” Semeia 14 (1979): 1-20.

Collins, John J. "Apocalypses and Apocalypticism: Early Jewish Apocalypticism." In The Anchor Bible Dictionary, volume 1, edited by David Noel Freedman, 282-8. New York: Doubleday, 1992.

Collins, John J. "Daniel, Book of." In The Anchor Bible Dictionary, volume 2, edited by David Noel Freedman, 29-37. New York: Doubleday, 1992.

Collins, John J. The Apocalyptic Imagination: An Introduction to Jewish Apocalyptic Literature, second edition. Grand Rapids: William B. Eerdmans, 1998.

Collins, John J. "From Prophecy to Apocalypticism: The Expectation of the End." In The Continuum History of Apocalypticism, edited by Bernard J. McGinn, John J. Collins, and Stephen J. Stein, 64-88. New York: Continuum, 2003.

Collins, John J. "The Zeal of Phinehas: The Bible and the Legitimation of Violence." Journal of Biblical Literature 122, no. 1 (2003): 3-21.

Connolly, William E. Capitalism and Christianity, American Style. Durham: Duke University Press, 2008.

Coyle, J. Kevin. "Augustine and Apocalyptic: Thoughts on the Fall of Rome, the Book of Revelation, and the End of the World." Florilegium 9 (1987): 1-34.

Craig, Campbell. Glimmer of a New Leviathan: Total War in the Realism of Niebuhr, Morgenthau, and Waltz. New York: Columbia University Press, 2003.

Cromwell, Oliver. The Speeches of Oliver Cromwell, edited by Ivan Roots. London: J.M. Dent and Sons, 1989.

Crossan, John Dominic. Jesus: A Revolutionary Biography. San Francisco: Harper San Francisco, 1994. 
Daniell, David. The Bible in English: Its History and Influence. New Haven: Yale University Press, 2003.

Davis, David Howard. Ignoring the Apocalypse: Why Planning to Prevent Environmental Catastrophe Goes Astray. Westport: Praeger, 2007.

De Man, Paul. “Semiology and Rhetoric.” Diacritics 3, no. 3 (1973): 27-33.

Derrida, Jacques. "Of an Apocalyptic Tone Newly Adopted in Philosophy." In Derrida and Negative Theology, edited by Harold Coward and Toby Foshay, 25-72. Albany: State University of New York Press, 1992.

Donne, John. The Complete Prose and Selected Poetry of John Donne, edited by Charles M. Coffin. New York: Modern Library, 2001.

Donnelly, Jack. Realism and International Relations. Cambridge: Cambridge University Press, 2000.

Dunne, Tim. "Theories as Weapons: E.H. Carr and International Relations." In E.H. Carr: A Critical Appraisal, edited by Michael Cox, 217-33. Houndsmills: Palgrave, 2000.

Ehrman, Bart D. Jesus: Apocalyptic Prophet of the New Millennium. New York: Oxford University Press, 1999.

Ehrman, Bart D. The New Testament: A Historical Introduction to the Early Christian Writings. New York: Oxford University, 2008.

Eisenbichler, Konrad. "Introduction." A Guide to Righteous Living and Other Works, translated by Konrad Eisenbickler, 1-34. Toronto: Centre for Reformation and Renaissance Studies, 2003.

Ellul, Jacques. Apocalypse: The Book of Revelation, translated by George W. Schreiner. New York: The Seabury Press, 1997. 
Emmerson, Richard K. and Ronald B. Herzman. The Apocalyptic Imagination in Medieval Literature. Philadelphia: University of Pennsylvania Press, 1992.

Euben, J. Peter. The Tragedy of Political Theory: The Road Not Taken. Princeton: Princeton University Press, 1990.

Euben, J. Peter. "The Politics of Nostalgia and Theories of Loss," in Vocations of Political Theory, edited by Jason A. Frank and John Tambornino, 73-83. Minneapolis: University of Minnesota Press, 2000.

Firth, Katharine R. The Apocalyptic Tradition in Reformation Britain. Oxford: Oxford University Press, 1979.

Flanagan, Thomas. "The Third Reich: Origins of a Millenarian Symbol." History of European Ideas 8, no. 4 (1987): 283-295.

Forde, Steven. "Varieties of Realism: Thucydides and Machiavelli," The Journal of Politics 54 (1992): 372-393.

Fredriksen, Paula. "Apocalypse and Redemption in Early Christianity: From John of Patmos to Augustine of Hippo." Vigilae Christianae 45, no. 2 (1992): 151-83.

Fredriksen, Paula. From Jesus to Christ: The Origins of the New Testament Images of Christ. New Haven: Yale University Press, 2000.

Frei, Christoph. Hans J. Morgenthau: An Intellectual Biography. Baton Rouge: Louisiana State University Press, 2001.

Friesen, Steven J. Imperial Cults and the Apocalypse of John: Reading Revelation in the Ruins. Oxford: Oxford University Press, 2001.

Fukuyama, Francis. The End of History and the Last Man. New York: Free Press, 1992.

Gardiner, Stephen M. The Perfect Moral Storm: The Ethical Tragedy of Climate Change. New York: Oxford University Press, 2011. 
Garsten, Bryan. Saving Persuasion: A Defense of Rhetoric and Judgment. Cambridge: Harvard University Press, 2006.

Gauthier, David. The Logic of Leviathan. Oxford: Clarendon, 1969.

Gilpin, Robert. War and Change in World Politics. Cambridge: Cambridge University Press, 1981.

Gilpin, Robert. "The Richness of the Tradition of Political Realism." In Neorealism and its Critics, edited by Robert O. Keohane, 301-21. New York: Columbia University Press, 1986.

Goldsmith, M.M. "Hobbes's Ambiguous Politics.” History of Political Thought 11, no. 4 (1990): 654-73.

Gray, John. "Faith in Reason: Secular Fantasies of a Godless Age." Harper's 316, no. 1892 (2008): 85-9.

Greene, Thomas M. "The End of Discourse in Machiavelli's 'Prince,"” Yale French Studies 67 (1984): $57-71$.

Gribben, Crawford. "Deconstructing the Geneva Bible: The Search for a Puritan Poetic." Literature and Theology 14, no. 1 (2000): 1-16.

Gribben, Crawford. The Puritan Millennium: Literature and Theology 1550-1682. Dublin: Four Courts Press, 2000.

Gross, Leo. "The Peace of Westphalia: 1648-1948." American Journal of International Law 42, no. 1 (1948): 20-41.

Gruen, Erich S. "Hellenism and Persecution: Antiochus IV and the Jews." In Hellenistic History and Culture, edited by Peter Green, 238-64. Berkeley and Los Angeles: University of California Press, 1993. 
Guilhot, Nicolas. "American Katechon: When Political Theology Became International Relations Theory," Constellations 17, no. 2 (2010): 224-53.

Gutierrez, Cathy. "The Millennium and Narrative Closure." In War in Heaven/Heaven on Earth: Theories of the Apocalyptic, edited by Stephen D. O'Leary and Glen S. McGee, 46-58. London: Equinox, 2005.

Guzzini, Stephano. Realism in International Relations and International Political Economy: The continuing story of a death foretold. London and New York: Routledge, 1998.

Hall, John R., with Philip D. Schuyler and Sylvaine Trinh. Apocalypse Observed: Religious Movements and Violence in North America, Europe, and Japan. New York: Routledge, 2000.

Haller, William. Foxe's First Book of Martyrs and the Elect Nation. London: Jonathan Cape, 1963.

Hanson, Paul D. The Dawn of Apocalyptic: The Historical and Sociological Roots of Jewish Apocalyptic Eschatology. Philadelphia: Fortress Press, 1975.

Hanson, Paul D. “Apocalypticism." In Interpreter's Dictionary of the Bible, Supplementary Volume, edited by Keith Crim, et al., 28-34. Nashville: Abington Press, 1976.

Hanson, Paul D. "Apocalypses and Apocalypticism: The Genre." In The Anchor Bible Dictionary, volume 1, edited by David Noel Freedman, 279-88. New York: Doubleday, 1992.

Hatfield, Rab. "Botticelli's Mystic Nativity, Savonarola and the Millennium." Journal of the Warburg and Courtauld Institutes 58 (1995): 89-114.

Helgerson, Richard. Forms of Nationhood: The Elizabethan Writing of England. Chicago: University of Chicago Press, 1992.

Hersey, John. Hiroshima. New York: Bantam, 1985. 
Hill, Christopher. Antichrist in Seventeenth-Century England. London: Verso, 1971.

Hill, Christopher. The Experience of Defeat: Milton and Some Contemporaries. New York: Viking, 1984.

Hobbes, Thomas. English Works of Thomas Hobbes, edited by William Molesworth. London: Longman, Brown, Green, and Longmans, 1839.

Hobbes, Thomas. Hobbes's Thucydides, edited by Richard Schlatter. New Brunswick: Rutgers University Press, 1975.

Hobbes, Thomas. Behemoth or the Long Parliament. Chicago: Chicago University Press, 1990.

Hobbes, Thomas. De Cive. In Man and Citizen, edited by Bernard Gert. Indianapolis: Hackett, 1991.

Hobbes, Thomas. Leviathan, edited by Edwin Curley. Indianapolis: Hackett Publishing Company, 1994.

Hoekstra, Kinch. "Disarming the Prophets: Thomas Hobbes and Predictive Power." Rivista di storia della filosofia 21, no. 1 (2004): 97-153.

Hoffman, Stanley. Janus and Minerva: Essays in the Theory and Practice of International Politics. Boulder: Westview Press, 1987.

Hollerich, Michael. "Carl Schmitt." In The Blackwell Companion to Political Theology, edited by Peter Scott and William T. Cavanaugh, 107-22. Malden: Blackwell, 2004.

Holmes, Stephen. "Introduction." In Behemoth or the Long Parliament, vii-1. Chicago: Chicago University Press, 1990.

Holmes, Stephen. Passions and Constraints: On the Theory of Liberal Democracy. Chicago: University of Chicago Press, 1995. 
Houlahan, Mark. "Leviathan (1651): Thomas Hobbes and Protestant Apocalypse." 1650-1850: Ideas, Aesthetics, and Inquiries in the Early Modern Era, volume 2, edited by Kevin L. Cope, 95-109. New York: AMS Press, 1996.

Hultgård, Anders. "Persian Apocalypticism." In The Continuum History of Apocalypticism, edited by Bernard J. McGinn, John J. Collins, and Stephen J. Stein, 30-63. New York: Continuum, 2003.

Jacobitti, Edmund E. "The Classical Heritage in Machiavelli's Histories: Symbol and Poetry as Historical Literature." In edited The Tragedy and Comedy of Machiavelli, edited by Vickie Sullivan, 176-192. New Haven: Yale University Press, 2000.

Jaspers, Karl. The Future of Mankind, translated by E.B. Ashton. Chicago: University of Chicago Press, 1958.

Johnston, David. The Rhetoric of Leviathan: Thomas Hobbes and the Politics of Cultural Transformation. Princeton: Princeton University Press, 1986.

Jordheim, Helge. "Conceptual History Between Chronos and Kairos-The Case of 'Empire."” Redescriptions: Yearbook of Political Thought and Conceptual History 11 (2007), edited by K. Lindroos and Kari Palonen: 115-45.

Kahn, Herman. Thinking About the Unthinkable. New York: Avon, 1962.

Kahn, Paul W. Four New Chapters on the Concept of Sovereignty. New York: Columbia University Press, 2011.

Kant, Immanuel. Practical Philosophy, translated and edited by Mary J. Gregor. Cambridge: Cambridge University Press, 1996.

Keller, Catherine. Apocalypse Now and Then: A Feminist Guide to the End of the World. Boston: Beacon Press, 1996.

Keller, Catherine. God and Power: Counter-apocalyptic Journeys. Minneapolis: Fortress Press, 2005. 
Kermode, Frank. The Sense of an Ending: Studies in the Theory of Fiction. New York: Oxford University Press, 1967.

Klein, Naomi. The Shock Doctrine: The Rise of Disaster Capitalism. New York: Picador, 2008.

Koskenniemi, Martti. The Gentle Civilizer of Nations: The Rise and Fall of International Law 1870-1960. Cambridge: Cambridge University Press, 2001.

Krasner, Stephen D. Sovereignty: Organized Hypocrisy. Princeton: Princeton University Press, 1999.

Landes, Richard. "Lest the Millennium be Fulfilled: Apocalyptic Expectations and the Pattern of Western Chronography 100-800 CE." In The Use and Abuse of Eschatology in the Middle, edited by Werner Verbeke, Daniel Verhelst, and Andries Welkenhuysen, 137211. Leuven: Leuven University Press, 1988.

Landes, Richard. "Millennialism." In Merriam-Webster's Encyclopedia of World Religions, edited by Wendy Doniger, 727-37. Springfield: Merriam-Webster, 1999.

Landes, Richard. "The Fear of an Apocalyptic Year 1000: Augustinian Historiography, Medieval and Modern Author(s)." Speculum 75, no. 1 (2000): 97-145.

Landes, Richard. "What Happens when Jesus Doesn't Come: Jewish and Christian Relations in Apocalyptic Time." In Millennial Violence: Past, Present and Future, edited by Jeffrey Kaplan, 245-59. London: Frank Cass, 2002.

Landes, Richard. "Rooster Crow, Owls Hoot: On the Dynamics of Apocalyptic Millennialism." In War in Heaven/Heaven on Earth: Theories of the Apocalyptic, edited by Stephen O’Leary and Glen S. McGhee, 19-46. London: Equinox, 2005.

Landes, Richard. Heaven on Earth: The Varieties of the Millennial Experience. Oxford: Oxford University Press, 2011.

Laurence, William L. Men and Atoms: The Discovery, the Uses and the Future of Atomic Energy. New York: Simon and Schuster, 1959. 
Lebow, Richard Ned. The Tragic Vision of Politics: Ethics, Interests and Orders. Cambridge: Cambridge: Cambridge University Press, 2003.

Lessay, Franck. "Hobbes's Covenant Theology and Its Political Implications," in The Cambridge Companion to Hobbes's Leviathan, edited by Patricia Springborg, 243-70. Cambridge: Cambridge University Press, 2007.

Levin, Meyer. "The child behind the secret door [Review of Anne Frank: The Diary of a Young Girl]." New York Times (June 15, 1952): BR 1.

Levine, Amy-Jill. "Daniel: Introduction and Notes," in The New Oxford Annotated Bible, New Revised Standard Version with Aprocrypha, fourth edition, edited by Michael D. Coogan, 1233-4. Oxford: Oxford University Press, 2010.

Lifton, Robert. The Broken Connection: On Death and the Continuity of Life. New York: Simon and Schuster, 1979.

Lifton, Robert J. "The Image of 'the End of the World': A Psychohistorical View." In Visions of Apocalypse: End or Rebirth?, edited by Saul Friedländer, Gerald Holton, Leo Marx, and Eugene Skolnikoff, 151-67. New York: Holmes and Meier, 1985.

Lifton, Robert Jay and Eric Markusen. The Genocidal Mentality: Nazi Holocaust and Nuclear Threat. New York: Basic Books, 1990.

Machiavelli, Niccolò. The Chief Works and Others, 3 volumes, translated by Allan Gilbert. Durham: Duke University Press, 1989.

Machiavelli, Niccolò. The Prince, translated by Harvey C. Mansfield. Chicago: University of Chicago Press, 1998.

Machiavelli, Niccolò. Discourses on Livy, translated by Harvey C. Mansfield and Nathan Tarcov. Chicago: University of Chicago Press, 1998. 
Machiavelli, Niccolò, et al. Machiavelli and His Friends: Their Personal Correspondence, translated by James B. Atkinson and David Sices. DeKalb: Northern Illinois University Press, 2004.

MacKinley, Jesse. "Despite Careful Calculations, the World Does Not End." New York Times, May 21, 2011. Accessed July 2011. http://www.nytimes.com/2011/05/22/us/22doomsday.html

MacKinley, Jesse. "An Autumn Date for the Apocalypse." New York Times, May 23, 2011. Accessed July 7, 2011. http://www.nytimes.com/2011/05/24/us/24rapture.html

Mansfield, Harvey C. Machiavelli's Virtue. Chicago: University of Chicago Press, 1996.

Markus, R.A. Saeculum: History and Society in the Theology of St. Augustine. Cambridge: Cambridge University Press, 1970.

Marrou, Henri. St. Augustine and his Influence Through the Ages, translated by Patrick Hepburne-Scott. New York: Harper Torchbooks, 1957.

Martelli, Mario. “Da Poliziano a Machiavelli: sull'epigramma dell'Occasione e sull'occasione.” Interpres 2 (1979): 230-54.

Martelli, Mario. "La logica provvidenzialistica e il capitolo XXVI del Principe." Interpres 4 (1982): 262-384.

Martinez, Ronald L. "Tragic Machiavelli." In Comedy and Tragedy of Machiavelli, edited by Vickie Sullivan, 102-119. New Haven: Yale University Press, 2000.

Martinich, A.P. The Two Gods of Leviathan: Thomas Hobbes on Religion and Politics. Cambridge: Cambridge University Press, 1992.

Martinich, A.P. Hobbes: A Biography. Cambridge: Cambridge University Press, 1999.

Mattingly, Garrett. The Armada. Boston: Mariner/Houghton Mifflin, 2005. 
McGinn, Bernard. "Revelation." In The Literary Guide to the Bible, edited by Robert Alter and Frank Kermode, 523-41. Cambridge: The Belknap Press of Harvard University Press, 1990.

McGinn, Bernard. Visions of the End: Apocalyptic Traditions in the Middle Ages. New York: Columbia University Press, 1998.

McGinn, Bernard. Antichrist: Two Thousand Years of the Human Fascination with Evil. New York: Columbia University Press, 2000.

Mearsheimer, John J. The Tragedy of Great Power Politics. New York: W.W. Norton \& Co., 2001.

Meier, Heinrich. Carl Schmitt and Leo Strauss: The Hidden Dialogue. Chicago: University of Chicago, 1985.

Ménissier, Thierry. "Prophétie, politique et action selon Machiavel." Les études philosophiques 66 (2003): 289-313.

Míguez, Néstor. "Apocalyptic and the Economy: A Reading of Revelation 18 From the Experience of Economic Exclusion." In Reading from This Place, vol. 2: Social Location and Biblical Interpretation in Global Perspective, edited by Francis F. Segovia and Mary Ann Tolbert, 250-62. Minneapolis: Fortress Press, 1995.

Mitgang, Herbert. "Truman's Newly Found Potsdam Notes Show Concerns on A-Bomb." New York Times (June 2, 1980): A14

Moltmann, Jürgen. "Covenant or Leviathan? Political Theology for Modern Times." Scottish Journal of Theology 47 (1994): 19-41.

Morgenthau, Hans J. "The Evil of Politics and the Ethics of Evil." Ethics 56, no. 1 (1945): 1-18.

Morgenthau, Hans J. Scientific Man vs. Power Politics. Chicago: University of Chicago Press, 1946. 
Morgenthau, Hans J. Politics Among Nations: The Struggle for Power and Peace. New York: Knopf, 1948.

Morgenthau, Hans J. "World Politics in the Mid-Twentieth Century." The Review of Politics 10, no. 2 (1948), 154-73.

Morgenthau, Hans J. "The Problem of Sovereignty Reconsidered." Columbia Law Review 48, no. 3 (1948): 341-65.

Morgenthau, Hans J. In Defense of the National Interest: A Critical Examination of American Foreign Policy. New York: Knopf, 1951.

Morgenthau, Hans J. Politics Among Nations: The Struggle for Power and Peace, second edition. New York: Alfred A. Knopf, 1954.

Morgenthau, Hans J. "Russian Technology and American Policy." Current History 34, no. 119 (1958): 129-35.

Morgenthau, Hans J. The Purpose of American Politics. New York: Alfred Knopf, 1960.

Morgenthau, Hans J. “An Atomic Philosophy.” Saturday Review (February 18, 1961): 18-9.

Morgenthau, Hans J. The Decline of Democratic Politics. Chicago: University of Chicago Press, 1962.

Morgenthau, Hans J. The Restoration of American Politics. Chicago: University of Chicago Press, 1962.

Morgenthau, Hans J. The Purpose of American Politics. New York: Vintage, 1964.

Morgenthau, Hans J. "Fragment of an Intellectual Autobiography: 1904-1932." In Truth and Tragedy: A Tribute to Hans J. Morgenthau, edited by Kenneth Thompson and Robert J. Myers, 6-7. New Brunswick: Transaction Books, 1984. 
Morgenthau, Hans J., et al. "Western Values and Total War." Commentary 32 (October 1961): 277-304.

Morgenthau, Hans J. and Reinhold Niebuhr. "The Ethics of War and Peace in the Nuclear Age." War/Peace Report (February 1967), 3-8.

Morgenthau, Hans J. and David Hein. Essays on Lincoln's Faith and Politics, edited by Kenneth W. Thompson. Lanham: University Press of America, 1983.

Murrow, Edward R. In Search of Light: The Broadcasts of Edward R. Murrow, 1938-1961, edited by Edward Bliss, Jr. London: Macmillan, 1968.

Myers, Robert J. U.S. Foreign Policy in the Twenty-First Century: The Relevance of Realism. Baton Rouge: Louisiana State University Press, 1999.

Najemy, John M. Between Friends: Discourses of Power and Desire in the Machiavelli-Vettori Letters of 1513-1515. Princeton: Princeton University Press, 1993.

O'Leary, Stephen D. Arguing the Apocalypse: A Theory of Millennial Rhetoric. Oxford: Oxford University Press, 1994.

Orr, Robert. "The Time Motif in Machiavelli." In Machiavelli and the Nature of Political Thought, edited by Martin Fleisher, 145-59. New York: Atheneum, 1972.

Osiander, Andreas. "Sovereignty, International Relations, and the Westphalian Myth." International Organization 55, no. 2 (2001): 251-87.

Palaver, Wolfgang. "Hobbes and the Katéchon: The Secularization of Sacrificial Christianity." Contagion: Journal of Violence, Mimesis and Culture 2 (1995): 57-74

Pangle, Thomas L. and Peter J. Ahrensdorf. Justice Among Nations: On the Moral Basis of Power and Peace. Lawrence: University Press of Kansas, 1999.

Peterson, David L. "Eschatology." In The Anchor Bible Dictionary, vol. 2, edited by David Noel Freedman, 575-9. New York: Doubleday, 1992. 
Pichler, Hans-Karl. "The Godfathers of 'Truth': Max Weber and Carl Schmitt in Morgenthau's Theory of Power Politics." Review of International Studies 24 (1997): 185-200.

Pitkin, Hannah Fenichel. Fortune is a Woman: Gender and Politics in the Thought of Niccolo Machiavelli, $2^{\text {nd }}$ edition. Chicago: University of Chicago Press, 1999.

Pocock, J.G.A. "The Onely Politician': Machiavelli, Harrington and Felix Raab." Historical Studies: Australia and New Zealand 12, no. 46 (1965-7): 165-96.

Pocock, J.G.A. "Time, History and Eschatology in the Thought of Thomas Hobbes." In The Diversity of History: Essays in honour of Sir Herbert Butterfield, edited by J.H. Elliott and H.G. Koenigsberger, 149-98. Ithaca: Cornell University Press, 1970.

Pocock, J.G.A. The Machiavellian Moment: Florentine Political Thought and the Atlantic Republican Tradition, second edition. Princeton: Princeton University Press, 2003.

Polizzotto, Lorenzo. The Elect Nation: The Savonarolan Movement in Florence 1494-1545. Oxford: Clarendon Press, 1994.

Popkin, R.H. "Savonarola and Cardinal Ximines: Millenarian Thinkers and Actors at the Eve of the Reformation." In Millenarianism and Messianism in Early Modern European Culture, volume 2, edited by Karl A. Kottman, 15-26. Boston: Kluwer, 2001.

Redles, David. Hitler's Millennial Reich: Apocalyptic Belief and the Search for Salvation. New York: New York University Press, 2005.

Redles, David. "Nazi End Times: The Third Reich as Millennial Reich." In End of Days: Essays on the Apocalypse from Antiquity to Modernity, edited by Karolyn Kinane and Michael A. Ryan, 173-196. Jefferson: McFarland and Company, 2009.

Reeves, Marjorie. Joachim of Fiore and the Prophetic Future. New York: Harper Torchbooks, 1976.

Reeves, Marjorie. The Influence of Prophecy in the Later Middle Ages: A Study in Joachimism. Notre Dame: University of Notre Dame Press, 1993. 
Rengger, Nicholas. "Tragedy of Scepticism? Defending the Anti-Pelagian Mind in World Politics." International Relations 19, no. 3 (2005): 321-8.

Reston, James. "Dawn of the Atom Era Perplexes Washington." New York Times (August 12, 1945): E6.

Rhodes, James M. The Hitler Movement: A Modern Millenarian Revolution. Stanford: Hoover Institution Press, 1980.

Rhodes, Richard. The Making of the Atomic Bomb. New York: Simon and Schuster, 1986.

Rice, Daniel. "Reinhold Niebuhr and Hans Morgenthau: A Friendship with Contrasting Shades of Realism," Journal of American Studies 42, no. 2 (2008): 255-91.

Ridolfi, Roberto. The Life of Girolamo Savonarola, translated by Cecil Grayson. New York: Knopf, 1959.

Ridolfi, Roberto. The Life of Niccolò Machiavelli, translated by Cecil Grayson. Chicago: University of Chicago Press, 1963.

Rogow, Arnold A. Radical in the Service of Reaction. New York: W.W. Norton, 1986.

Rose, Kenneth D. One Nation Underground: The Fallout Shelter in American Culture. New York: New York University Press, 2001.

Roskies, David G. Against the Apocalypse: Reponses to Catastrophe in Modern Jewish Culture. Cambridge: Harvard University Press, 1984.

Sage, Steven F. Ibsen and Hitler: The Playwright, the Plagiarist, and the Plot for the Third Reich. New York: Basic Books, 2009.

Sasso, Gennaro. Machiavelli e gli antichi, volume 2. Milan: Ricciardo Ricciardi Editore, 1988. 
Savonarola, Girolamo. A Guide to Righteous Living and Other Works, translated by Konrad Eisenbichler. Toronto: Centre for Reformation and Renaissance Studies, 2003.

Schedler, Andreas. "Mapping Contingency." In Political Contingency: Studying the Unexpected, the Accidental, and the Unforeseen, edited by Ian Shapiro and Sonu Bedi, 54-78. New York: New York University Press, 2007.

Scheuerman, William E. "Was Morgenthau a Realist? Revisiting Scientific Man Vs. Power Politics," Constellations 14, no. 4 (2007): 506-30.

Scheuerman, William E. "Carl Schmitt and Hans Morgenthau: Realism and beyond." In Realism Reconsidered: The Legacy of Hans Morgenthau in International Relations, edited by Michael C. Williams, 62-92. Oxford: Oxford University Press, 2007.

Scheuerman, William E. Hans Morgenthau: Realism and Beyond. Cambridge: Polity, 2009.

Schmitt, Carl. The Concept of the Political, translated by George Schwab. New Brunswick: Rutgers, 1976.

Schmitt, Carl. "The Age of Neutralizations and Depoliticizations" (1929), in The Concept of the Political, translated by George Schwab, 80-96. Chicago: University of Chicago Press, 2007.

Schmitt, Carl. Political Theology: Four Chapters on the Concept of Sovereignty, translated by George Schwab. Chicago: University of Chicago Press, 1985.

Schmitt, Carl. The Crisis of Parliamentary Democracy, translated by Ellen Kennedy. Cambridge: MIT Press, 1988.

Schmitt, Carl. The Nomos of the Earth in the International Law of the Jus Publicum Europaeum, trans. G.J. Ulmen. New York: Telos Press, 2003.

Schüssler Fiorenza, Elisabeth. The Book of Revelation: Justice and Judgment. Philadelphia: Fortress, 1985. 
Schwartz, Joel. "Hobbes and the Two Kingdoms of God." Polity 18, no. 1 (1985): 7-24.

Scott, James C. Domination and the Arts of Resistance: Hidden Transcripts. New Haven: Yale University Press, 1990.

Shapiro, Gary. "Reading and Writing in the Text of Hobbes's Leviathan." Journal of the History of Philosophy 18, no. 2 (1980): 147-57.

Shaw, Jane. Miracles in Enlightenment England. New Haven: Yale University Press, 2006.

Sherwin, Martin J. A World Destroyed: Hiroshima and the Origins of the Arms Race. New York: Vintage, 1987.

Skinner, Quentin. "Meaning and Understanding in the History of Ideas." History and Theory 8, no. 1 (1969): 3-53.

Skinner, Quentin. "The rise of, challenge to and prospects for a Collingwoodian approach to the history of political thought." In The History of Political Thought in National Context, edited by Dario Castiglione and Iain Hampsher-Monk, 175-188. Cambridge: Cambridge University Press, 2001.

Skinner, Quentin. Reason and Rhetoric in the Philosophy of Thomas Hobbes. Cambridge: Cambridge University Press, 1997.

Speer II, James P. “Hans Morgenthau and the World State.” World Politics 20, no. 2 (1968): 207-227.

Strauss, Leo. Natural Right and History. Chicago: University of Chicago Press, 1953.

Strauss, Leo. Thoughts on Machiavelli. Chicago: University of Chicago Press, 1978.

Strauss, Leo. "The Three Waves of Modernity." In An Introduction to Political Philosophy: Ten Essays by Leo Strauss, edited by Hilail Gildin, 81-98. Detroit: Wayne State University Press, 1989. 
Strong, Tracy B. "How to Write Scripture: Words, Authority, and Politics in Thomas Hobbes." Critical Inquiry, 20, no. 1 (1993): 128-159.

Strong, Tracy B. "Forward: Carl Schmitt and Thomas Hobbes: Myth and Politics." In Carl Schmitt, The Leviathan in the State Theory of Thomas Hobbes: Meaning and Failure of a Political Symbol, translated by George Schwab and Erna Hilfstein, vii-xxviii. Chicago: University of Chicago Press, 2008.

Stubbs, Robert. John Donne: The Reformed Soul. New York: W.W. Norton, 2007.

Sullivan, Vickie B. "Introduction." In The Comedy and Tragedy of Machiavelli: Essays on the Literary Works, edited by Vickie B. Sullivan, ix-xxi. New Haven: Yale University Press, 2000.

Symmons, Edward. Scripture vindicated from the mis-apprehensions, mis-interpretations, and mis-applications of Mr. Stephen Marshall. [Electronic edition]. Oxford: Leonard Lichfield, 1645.

Taylor, Charles. Modern Social Imaginaries. Durham: Duke University Press, 2004.

Taylor, Charles. A Secular Age. Cambridge: Harvard University Press, 2007.

Teschke, Benno. "Theorizing the Westphalian System of States: International Relations from Absolutism to Capitalism." European Journal of International Relations 8, no. 1 (2002): $5-48$.

Thompson, Leonard. The Book of Revelation: Apocalypse and Empire. New York: Oxford University Press, 1990.

Time Magazine. "Civil Defense: The Sheltered Life." Time. October 20, 1961. March 13, 2011. http://www.time.com/time/magazine/article/0,9171,872787-9,00.html.

Trexler, Richard. Public Life in Renaissance Florence. New York: Academic Press, 1980. 
Vandercook, Wm. F. "Making the Very Best of the Very Worst: The 'Human Effects of Nuclear Weapons' Report of 1956.” International Security 11, no. 1 (1986): 184-195.

Vasquez, John. The Power of Power Politics: From Classical Realism to Neotraditionalism. Cambridge: Cambridge University Press, 1998.

Vaughan, Geoffrey M. "The Audience of Leviathan and the Audience of Hobbes's Political Philosophy." History of Political Thought 22, no. 3 (2001): 448-471.

Voegelin, Eric. The New Science of Politics: An Introduction. Chicago: University of Chicago Press, 1952.

Walzer, Michael. "On the Role of Symbolism in Political Thought," Political Science Quarterly 82, no. 2 (1967): 191-204.

Weart, Spencer R. Nuclear Fear: A History of Images. Cambridge: Harvard University Press, 1988.

Weinstein, Donald. "Millenarianism in a Civic Setting: The Savonarola Movement in Florence." In Millennial Dreams in Action: Essays in Comparative Study, Comparative Studies in History and Society, Supplement 2, 187-203. The Hague: Mouton and Co., 1962.

Weinstein, Donald. "The Myth of Florence." In Florentine Studies: Politics and Society in Renaissance Florence, edited by Nicolai Rubinstein, 15-44. Evanston: Northwestern University Press, 1968.

Weinstein, Donald. Savonarola and Florence: Prophecy and Patriotism in the Renaissance. Princeton: Princeton University Press, 1970.

Wiesel, Elie. "A Vision of Apocalypse," translated by Joan Grimbert, World Literature Today 58 , no. 2 (1984): 194-7.

Wills, Lawrence M. "Daniel Introduction and Annotations." In The Jewish Study Bible, Tanakh Translation, edited by Adele Berlin and Mark Zvi Brettler, 1640-2. New York: Oxford University Press, 2004. 
Williams, Michael C. The Realist Tradition and the Limits of International Relations. Cambridge: Cambridge University Press, 2005.

Wilson, Woodrow. Address to Congress. April 2, 1917. Accessed February 25, 2011. $<$ http://wwi.lib.byu.edu/index.php/Wilson's_War_Message_to_Congress $>$.

Wilson, Woodrow. Address to Joint Session of Congress. January 8, 1918. Accessed February 25, 2011. <http://wwi.lib.byu.edu/index.php/President_Wilson's_Fourteen_Points>.

Wistrich, Robert. Hitler's Apocalypse: Jews and the Nazi Legacy. New York: St. Martin's Press, 1985.

Wojcik, Daniel. The End of the World as We Know It: Faith, Fatalism, and Apocalypse in America. New York: New York University Press, 1997.

Wolin, Sheldon S. Politics and Vision: Continuity and Innovation in Western Political Thought, Expanded Edition. Princeton: Princeton University Press, 2004.

Wright, Paul R. "Machiavelli's City of God: Civic Humanism and Augustinian Terror." In Augustine and Politics, edited by John Doody, Kevin L. Hughes, and Kim Paffenroth, 297-336. Lanham: Lexington Books, 2005.

Yarbro Collins, Adela. Crisis and Catharsis: The Power of Apocalypse. Philadelphia: The Westminster Press, 1984.

Yarbro Collins, Adela. Cosmology and Eschatology in Jewish and Christian Apocalypticism. Leiden: E.J. Brill, 1996.

Yarbro Collins, Adela. "The Book of Revelation." In The Continuum History of Apocalypticism, edited by Bernard McGinn, John J. Collins, and Stephen J. Stein, 195217. New York: Continuum, 2003.

Yates, Frances Amelia. Astraea: The Imperial Theme in the Sixteenth Century. Harmondsworth: Penguin, 1977. 